GROUNDWATER RESOURCES PROGRAM

\title{
Steady-State Numerical Groundwater Flow Model of the Great Basin Carbonate and Alluvial Aquifer System
}

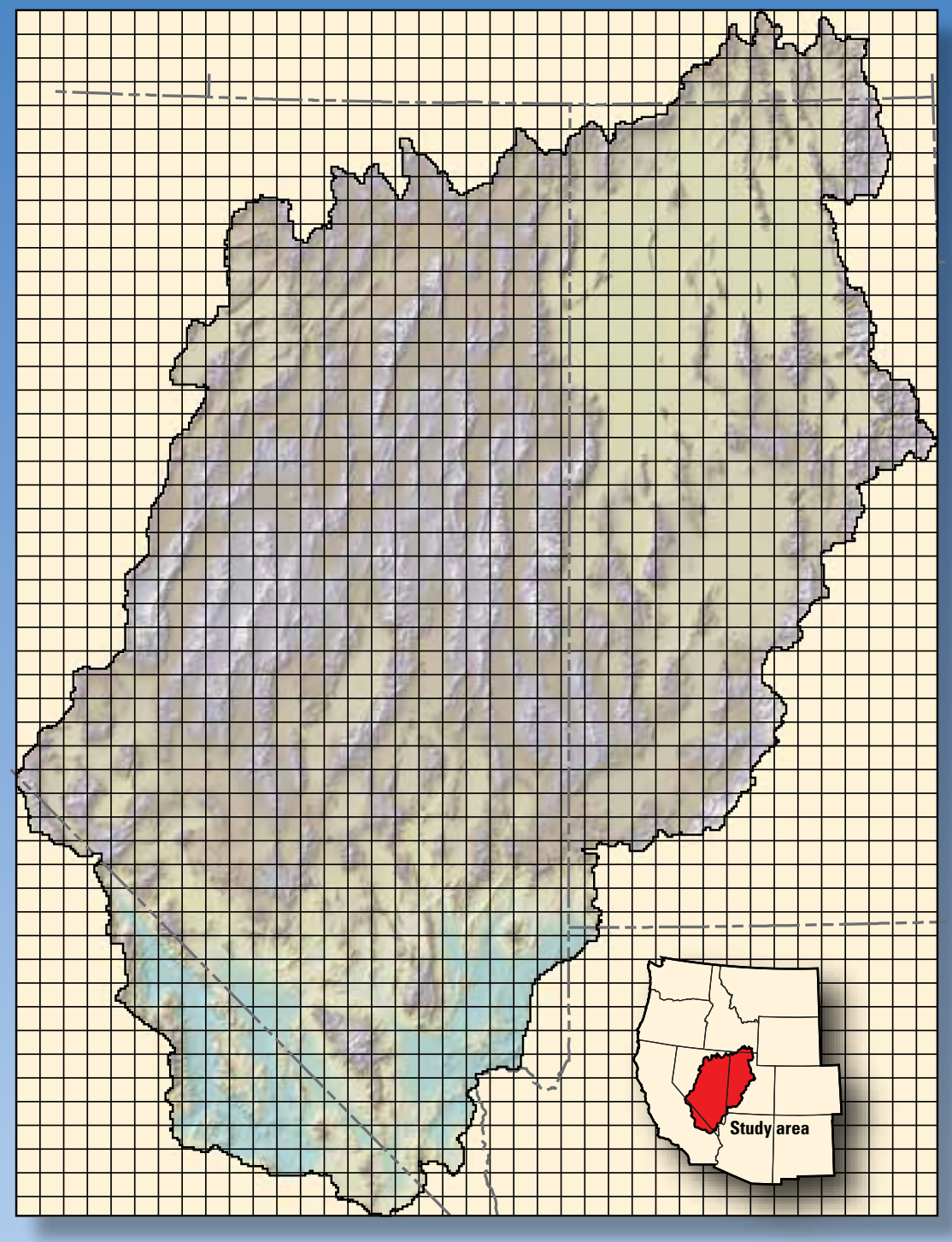

Scientific Investigations Report 2014-5213

U.S. Department of the Interior

U.S. Geological Survey 



\section{Steady-State Numerical Groundwater Flow Model of the Great Basin Carbonate and Alluvial Aquifer System}

By Lynette E. Brooks, Melissa D. Masbruch, Donald S. Sweetkind, and Susan G. Buto

Scientific Investigations Report 2014-5213 


\title{
U.S. Department of the Interior SALLY JEWELL, Secretary
}

\section{U.S. Geological Survey \\ Suzette M. Kimball, Acting Director}

\author{
U.S. Geological Survey, Reston, Virginia: 2014
}

For more information on the USGS - the Federal source for science about the Earth, its natural and living resources, natural hazards, and the environment, visit http://www.usgs.gov or call 1-888-ASK-USGS.

For an overview of USGS information products, including maps, imagery, and publications, visit http://Www.usgs.gov/pubprod.

To order this and other USGS information products, visit http://store.usgs.gov.

Any use of trade, firm, or product names is for descriptive purposes only and does not imply endorsement by the U.S. Government.

Although this information product, for the most part, is in the public domain, it also may contain copyrighted materials as noted in the text. Permission to reproduce copyrighted items must be secured from the copyright owner.

Suggested citation:

Brooks, L.E., Masbruch, M.D., Sweetkind, D.S., and Buto, S.G., 2014, Steady-state numerical groundwater flow model of the Great Basin carbonate and alluvial aquifer system: U.S. Geological Survey Scientific Investigations Report 2014-5213, 124 p., 2 pl. http://dx.doi.org/10.3133/sir20145213.

ISSN 2328-0328 (online) 


\section{Contents}

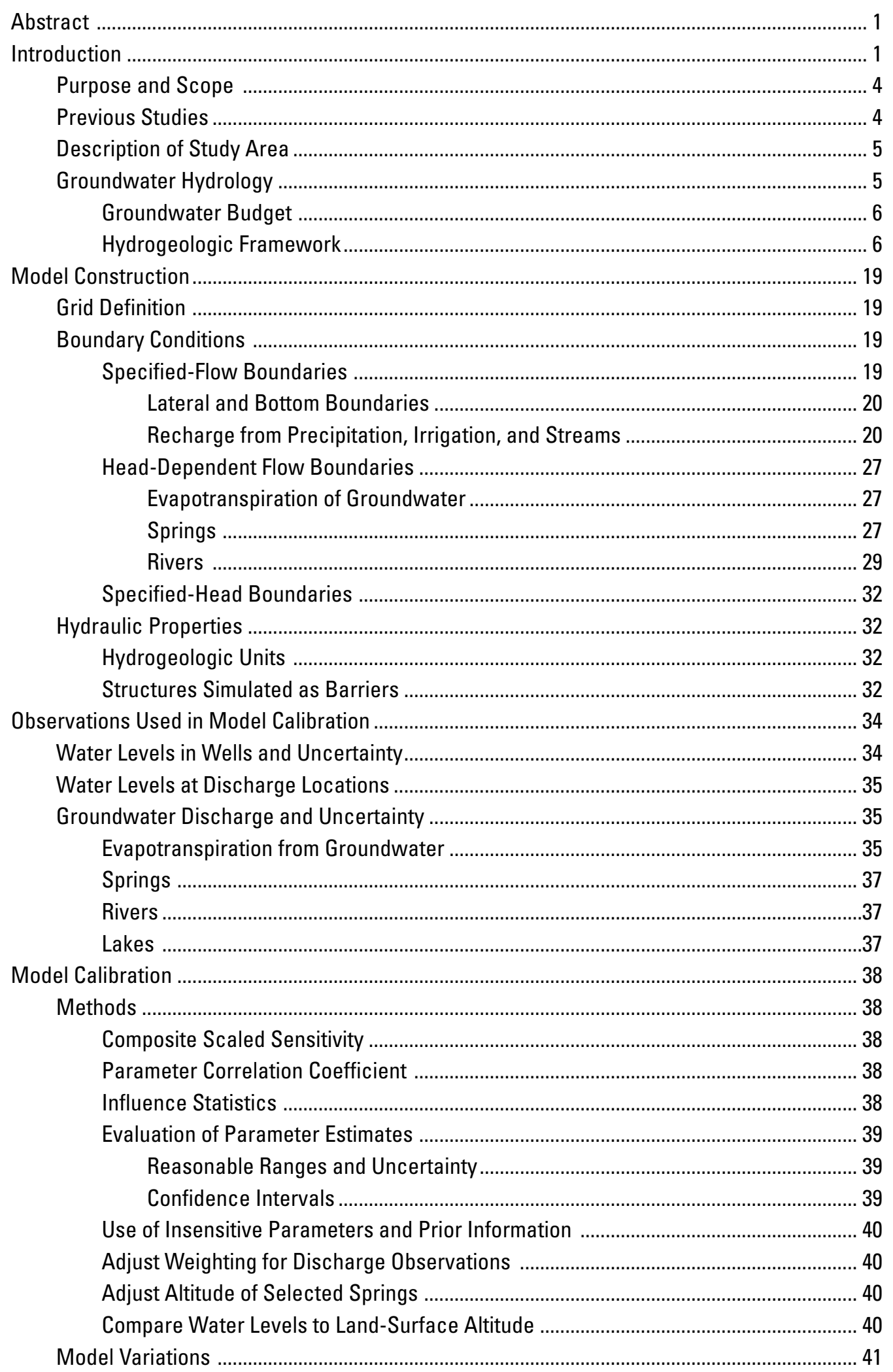


Final Calibrated Model and Parameter Values ........................................................................ 43

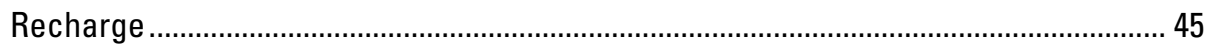

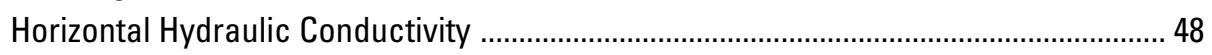

Non-Carbonate Confining Unit and Thrusted Non-Carbonate Confining Unit ...... 48

Lower Carbonate Aquifer Unit and Thrusted Lower Carbonate Aquifer Unit ....... 49

Upper Siliciclastic Confining Unit ........................................................................... 49

Upper Carbonate Aquifer Unit .......................................................................... 49

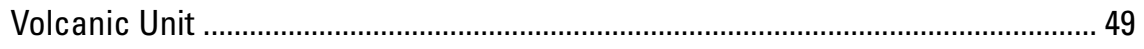

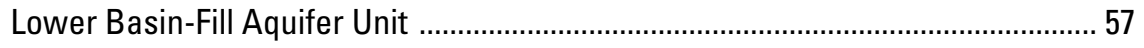

Upper Basin-Fill Aquifer Unit .............................................................................. 57

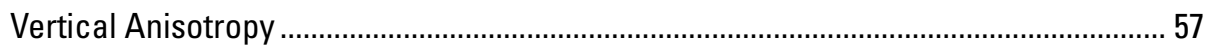

Drain and River Conductance ............................................................................... 57

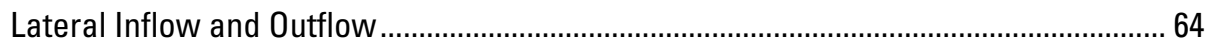

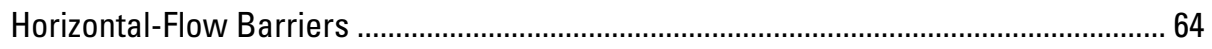

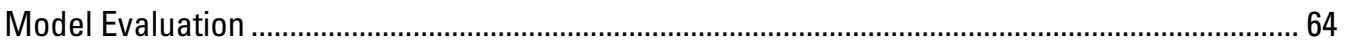

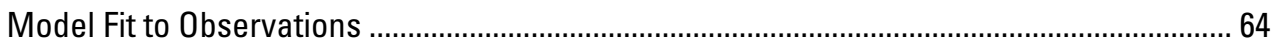

Water-Level Observations ...................................................................................... 65

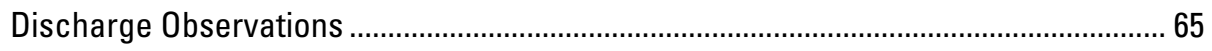

Simulated Water-Level Contours ................................................................................... 67

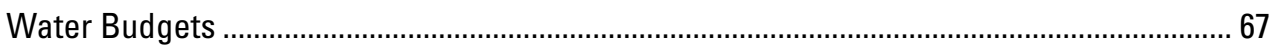

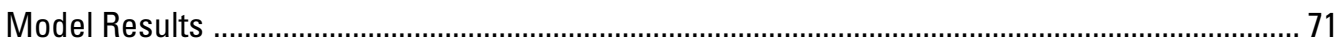

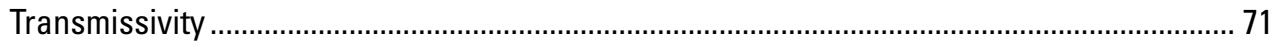

Vertical Groundwater Movement and Deep Flow ......................................................... 73

Simulated Groundwater Flow Regions ........................................................................ 73

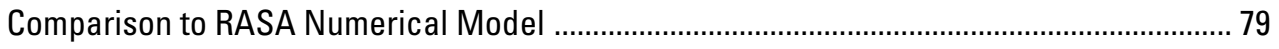

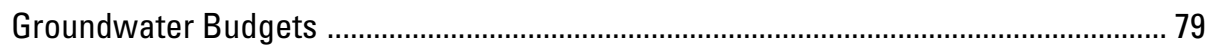

Simulated Water-Level Contours ........................................................................... 81

Comparison to DVRFS Numerical Model........................................................................ 81

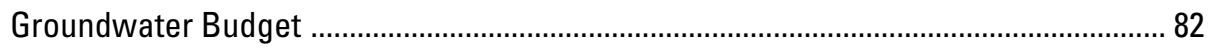

Simulated Water-Level Contours .............................................................................. 83

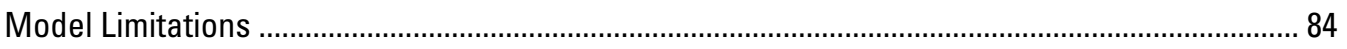

Hydrogeologic Framework and Model Grid Limitations ..................................................... 84

Recharge and Discharge Boundary Limitations ............................................................ 84

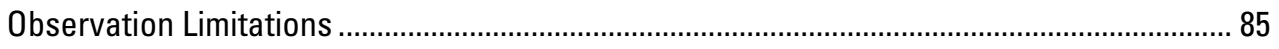

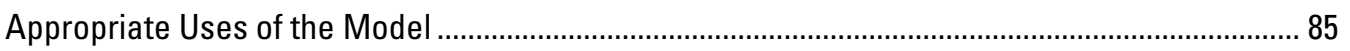

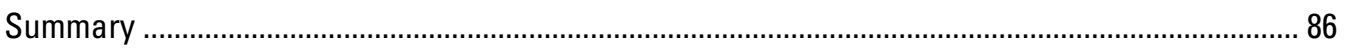

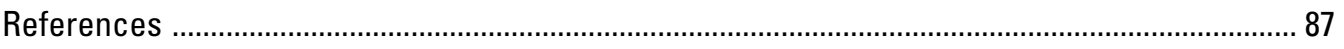

Appendix 1. Discharge Boundaries, Observations, and Error Analysis Used in the Numerical

Groundwater Flow Model of the Great Basin Carbonate and Alluvial Aquifer System

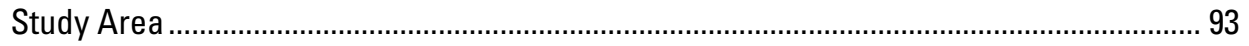

Appendix 2. Water-Level Observations and Error Analysis Used in the Numerical Groundwater Flow Model of the Great Basin Carbonate and Alluvial Aquifer System

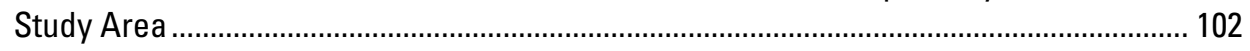

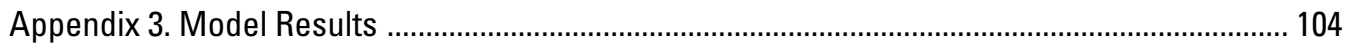

Appendix 4. Hydrogeologic Zones, Model Parameter Description, and Model Parameter Distribution 


\section{Figures}

1. Map showing location of the model grid for the numerical groundwater flow model of the Great Basin carbonate and alluvial aquifer system .

2. Map showing location of groundwater flow systems, selected previous regional groundwater studies, and regional model areas within the Great Basin carbonate and alluvial aquifer system study area

3. Cross sections showing hydrogeologic units and model layers in the numerical groundwater flow model, Great Basin carbonate and alluvial aquifer system study area .......... 8

4. Map showing thickness of the non-carbonate confining unit in the numerical groundwater flow model, Great Basin carbonate and alluvial aquifer system study area ........ 10

5. Map showing thickness of the lower carbonate aquifer unit in the numerical groundwater flow model, Great Basin carbonate and alluvial aquifer system study area ........ 11

6. Map showing thickness of the upper siliciclastic confining unit in the numerical groundwater flow model, Great Basin carbonate and alluvial aquifer system study area

7. Map showing thickness of the upper carbonate aquifer unit in the numerical groundwater flow model, Great Basin carbonate and alluvial aquifer system study area ........ 13

8. Map showing thickness of the thrusted non-carbonate confining unit in the numerical groundwater flow model, Great Basin carbonate and alluvial aquifer system study area

9. Map showing thickness of the thrusted lower carbonate aquifer unit in the numerical groundwater flow model, Great Basin carbonate and alluvial aquifer system study area

10. Map showing thickness of the volcanic unit in the numerical groundwater flow model, Great Basin carbonate and alluvial aquifer system study area

11. Map showing thickness of the lower basin-fill aquifer unit in the numerical groundwater flow model, Great Basin carbonate and alluvial aquifer system study area

12. Map showing thickness of the upper basin-fill aquifer unit in the numerical groundwater flow model, Great Basin carbonate and alluvial aquifer system study area ........ 18

13. Map showing rate of conceptual recharge and runoff from various sources in the Great Basin carbonate and alluvial aquifer system study area

14. Map showing distribution of observed evapotranspiration of groundwater in the numerical flow model, Great Basin carbonate and alluvial aquifer system study area

15. Diagram showing calculation of drain conductance used to simulate evapotranspiration of groundwater in the numerical flow model, Great Basin carbonate and alluvial aquifer system study area

16. Map showing location of and observed discharge to simulated springs and location of specified-head boundaries in the numerical groundwater flow model, Great Basin carbonate and alluvial aquifer system study area

17. Map showing location of and observed discharge to simulated rivers in the numerical groundwater flow model, Great Basin carbonate and alluvial aquifer system study area

18. Map showing major faults and horizontal-flow barriers representing selected faults in the numerical groundwater flow model, Great Basin carbonate and alluvial aquifer system study area

19. Map showing depth distribution of well openings for water-level observations used in the numerical groundwater flow model, Great Basin carbonate and alluvial aquifer system study area 
20. Bar chart showing composite scaled sensitivities for the initial version of the numerical groundwater flow model, Great Basin carbonate and alluvial aquifer system study area

21. Bar chart showing composite scaled sensitivities for final parameters in the numerical groundwater flow model, Great Basin carbonate and alluvial aquifer system study area

22. Graph showing values and linear confidence intervals of final parameters in the numerical groundwater flow model, Great Basin carbonate and alluvial aquifer system study area

23. Map showing distribution of parameter values for in-place recharge in the numerical groundwater flow model, Great Basin carbonate and alluvial aquifer system study area

24. Map showing distribution of simulated recharge in the numerical groundwater flow model, Great Basin carbonate and alluvial aquifer system study area ...... 47

25. Map showing distribution of hydraulic conductivity of the non-carbonate confining unit in the numerical groundwater flow model, Great Basin carbonate and alluvial aquifer system study area

26. Map showing distribution of hydraulic conductivity of the thrusted non-carbonate confining unit in the numerical groundwater flow model, Great Basin carbonate and alluvial aquifer system study area

27. Map showing distribution of hydraulic conductivity of the lower carbonate aquifer unit in the numerical groundwater flow model, Great Basin carbonate and alluvial aquifer system study area

28. Map showing distribution of hydraulic conductivity of the thrusted lower carbonate aquifer unit in the numerical groundwater flow model, Great Basin carbonate and alluvial aquifer system study area

29. Map showing distribution of hydraulic conductivity of the upper siliciclastic confining unit in the numerical groundwater flow model, Great Basin carbonate and alluvial aquifer system study area

30. Map showing distribution of hydraulic conductivity of the upper carbonate aquifer unit in the numerical groundwater flow model, Great Basin carbonate and alluvial aquifer system study area

31. Map showing distribution of hydraulic conductivity of the volcanic unit in the numerical groundwater flow model, Great Basin carbonate and alluvial aquifer system study area

32. Map showing distribution of hydraulic conductivity of the lower basin-fill aquifer unit in the numerical groundwater flow model, Great Basin carbonate and alluvial aquifer system study area

33. Map showing distribution of hydraulic conductivity of the upper basin-fill aquifer unit in the numerical groundwater flow model, Great Basin carbonate and alluvial aquifer system study area

34. Map showing distribution of vertical anisotropy of the upper basin-fill aquifer unit and volcanic unit in the numerical groundwater flow model, Great Basin carbonate and alluvial aquifer system study area

35. Map showing distribution of vertical anisotropy of the lower basin-fill aquifer unit in the numerical groundwater flow model, Great Basin carbonate and alluvial aquifer system study area

36. Map showing distribution of parameter values for evapotranspiration in the numerical groundwater flow model, Great Basin carbonate and alluvial aquifer system study area 
37. Map showing distribution of simulated evapotranspiration in the numerical groundwater flow model, Great Basin carbonate and alluvial aquifer system study area ........ 63

38. Graphs showing weighted residuals in the numerical groundwater flow model, Great Basin carbonate and alluvial aquifer system study area 66

39. Map showing direction of simulated subsurface flow between groundwater flow systems in the numerical flow model, Great Basin carbonate and alluvial aquifer system study area

40. Map showing simulated transmissivity in the numerical groundwater flow model, Great Basin carbonate and alluvial aquifer system study area

41. Map showing simulated vertical gradient between model layers 1 and 8 in the numerical groundwater flow model, Great Basin carbonate and alluvial aquifer system study area

42. Map showing model regions, simulated recharge, and simulated discharge in the numerical groundwater flow model, Great Basin carbonate and alluvial aquifer system study area

43. Map showing model regions in the numerical groundwater flow model and previous boundaries in the Great Basin carbonate and alluvial aquifer system study area ......... 78

44. Map showing Death Valley regional groundwater flow system model boundary segments, Nevada and California

A3-1. Map showing direction of simulated subsurface flow between hydrographic areas in the numerical groundwater flow model, Great Basin carbonate and alluvial aquifer system study area

A4-1. Map showing hydrogeologic zones and distribution of model parameters defining the hydraulic conductivity of the non-carbonate confining unit in the numerical groundwater flow model, Great Basin carbonate and alluvial aquifer system study area

A4-2. Maps and diagram showing zonation of the lower carbonate aquifer unit in the numerical ground-water flow model, Great Basin carbonate and alluvial aquifer system study area

A4-3. Map showing hydrogeologic zones and distribution of model parameters defining the hydraulic conductivity of the upper carbonate aquifer unit in the numerical groundwater flow model, Great Basin carbonate and alluvial aquifer system study area

A4-4. Map showing hydrogeologic zones and distribution of model parameters defining the hydraulic conductivity of the lower basin-fill aquifer unit in the numerical groundwater flow model, Great Basin carbonate and alluvial aquifer system study area

A4-5. Map showing hydrogeologic zones and distribution of model parameters defining the hydraulic conductivity of the upper basin-fill aquifer unit in the numerical groundwater flow model, Great Basin carbonate and alluvial aquifer system study area

A4-6. Map showing distribution of recharge parameters in the numerical groundwater flow model, Great Basin carbonate and alluvial aquifer system study area

A4-7. Map showing distribution of evapotranspiration parameters in the numerical groundwater flow model, Great Basin carbonate and alluvial aquifer system study area 


\section{Tables}

1. Annual groundwater recharge for predevelopment conditions for each of the 17 groundwater flow systems within the Great Basin carbonate and alluvial aquifer system study area

2. Annual groundwater discharge for predevelopment conditions for each of the 17 groundwater flow systems within the Great Basin carbonate and alluvial aquifer system study area

3. Horizontal hydraulic-conductivity estimates of hydrogeologic units in the Death Valley regional groundwater flow system and the Great Basin carbonate and alluvial aquifer system study area 9

4. Summary statistics of observations in the numerical groundwater flow model, Great Basin carbonate and alluvial aquifer system study area

5. Number of observation wells with top and bottom of open interval in each model layer in the numerical groundwater flow model, Great Basin carbonate and alluvial aquifer system study area

6. Estimates of properties describing parameter values for recharge, drains, rivers, horizontal-flow barriers, and vertical anisotropy in the numerical groundwater flow model, Great Basin carbonate and alluvial aquifer system study area

7. Prior information statistics for selected parameters in the numerical groundwater flow model, Great Basin carbonate and alluvial aquifer system study area

8. Summary statistics for measures of model fit in the numerical groundwater flow model, Great Basin carbonate and alluvial aquifer system study area

9. Summary of percent of discharge simulated in the numerical groundwater flow model, Great Basin carbonate and alluvial aquifer system study area

10. Comparison of conceptual and simulated recharge and discharge for each groundwater flow system in the numerical groundwater flow model, Great Basin carbonate and alluvial aquifer system study area.

11. Model-predicted flow between groundwater flow systems in the numerical groundwater flow model, Great Basin carbonate and alluvial aquifer system study area

12. Groundwater budgets for the simulated groundwater regions and subregions in the numerical groundwater flow model, Great Basin carbonate and alluvial aquifer system study area

13. Simulated discharge for each model region in the numerical groundwater flow model, Great Basin carbonate and alluvial aquifer system study area 77

14. Comparison of simulated groundwater budgets in the Regional Aquifer-System Analysis (RASA) model to simulated groundwater budgets within the RASA model boundary in the numerical groundwater flow model, Great Basin carbonate and alluvial aquifer system study area

15. Comparison of simulated steady-state groundwater budgets in the Death Valley regional flow system numerical groundwater flow model and the current numerical groundwater flow model, Great Basin carbonate and alluvial aquifer system study area

A1-1. Model observations of evapotranspiration of groundwater, including selected springs and rivers, in the numerical groundwater flow model, Great Basin carbonate and alluvial aquifer system study area

A1-2. Spring discharge observations in the numerical groundwater flow model, Great Basin carbonate and alluvial aquifer system study area

A1-3. Selected springs not simulated explicitly in the numerical groundwater flow model, Great Basin carbonate and alluvial aquifer system study area 
A1-4. Observed discharge to mountain rivers in the numerical groundwater flow model, Great Basin carbonate and alluvial aquifer system study area ..................................... 95

A1-5. Basin rivers simulated using the River Package in the numerical groundwater flow model, Great Basin carbonate and alluvial aquifer system study area 96

A1-6. Selected mountain streams not simulated in the numerical groundwater flow model, Great Basin carbonate and alluvial aquifer system study area 97

A1-7. Selected basin rivers not simulated using the River Package in the numerical groundwater flow model, Great Basin carbonate and alluvial aquifer system study area ........ 98

A1-8. Groundwater discharge to lakes simulated as specified-head boundaries in the numerical groundwater flow model, Great Basin carbonate and alluvial aquifer system study area

A1-9. Supplemental data for springs used as observations in the numerical groundwater flow model, Great Basin carbonate and alluvial aquifer system study area

A2-1. Well data, water-level observations, uncertainty, simulated values, and simulated residuals for observations of water levels in wells in the numerical groundwater flow model, Great Basin carbonate and alluvial aquifer system study area

A2-2. Selected wells in which water-level data were not used as observations in the numerical groundwater flow model, Great Basin carbonate and alluvial aquifer system study area

A3-1. Simulated discharge at each discharge observation in the numerical groundwater flow model, Great Basin carbonate and alluvial aquifer system study area

A3-2. Comparison of conceptual and simulated recharge and discharge for each hydrographic area in the numerical groundwater flow model, Great Basin carbonate and alluvial aquifer system study area

A3-3. Model-predicted flow between hydrographic areas in the numerical groundwater flow model, Great Basin carbonate and alluvial aquifer system study area

A4-1. Hydrogeologic zones, model zones, and parameter values and statistics for horizontal hydraulic conductivity of the confining units in the numerical groundwater flow model, Great Basin carbonate and alluvial aquifer system study area

A4-2. Hydrogeologic zones, model zones, and parameter values and statistics for horizontal hydraulic conductivity of the carbonate aquifer units in the numerical groundwater flow model, Great Basin carbonate and alluvial aquifer system study area

A4-3. Hydrogeologic zones, model zones, and parameter values and statistics for horizontal hydraulic conductivity of the volcanic and basin fill units in the numerical groundwater flow model, Great Basin carbonate and alluvial aquifer system study area

A4-4. Model zones, multiplier arrays, and parameter values and statistics for recharge and lateral flow boundaries in the numerical groundwater flow model, Great Basin carbonate and alluvial aquifer system study area

A4-5. Parameter values and statistics for horizontal-to-vertical anisotropy of all hydrogeologic units in the numerical groundwater flow model, Great Basin carbonate and alluvial aquifer system study area

A4-6. Parameter values and statistics for evapotranspiration, drain conductance, and river conductance in the numerical groundwater flow model, Great Basin carbonate and alluvial aquifer system study area

A4-7. Parameter values and statistics for the hydraulic characteristic of horizontalflow barriers in the numerical groundwater flow model, Great Basin carbonate and alluvial aquifer system study area 


\section{Conversion Factors and Datums}

Inch/Pound to SI

\begin{tabular}{|c|c|c|}
\hline Multiply & By & To obtain \\
\hline \multicolumn{3}{|c|}{ Length } \\
\hline inch (in.) & 2.54 & centimeter $(\mathrm{cm})$ \\
\hline inch (in.) & 25.4 & millimeter $(\mathrm{mm})$ \\
\hline foot $(\mathrm{ft})$ & 0.3048 & meter $(\mathrm{m})$ \\
\hline mile (mi) & 1.609 & kilometer $(\mathrm{km})$ \\
\hline \multicolumn{3}{|c|}{ Area } \\
\hline square mile $\left(\mathrm{mi}^{2}\right)$ & 2.590 & square kilometer $\left(\mathrm{km}^{2}\right)$ \\
\hline \multicolumn{3}{|c|}{ Flow rate } \\
\hline acre-foot per year (acre-ft/yr) & 1,233 & cubic meter per year $\left(\mathrm{m}^{3} / \mathrm{yr}\right)$ \\
\hline acre-foot per year (acre-ft/yr) & 0.001233 & cubic hectometer per year $\left(\mathrm{hm}^{3} / \mathrm{yr}\right)$ \\
\hline foot per day (ft/d) & 0.3048 & meter per day $(\mathrm{m} / \mathrm{d})$ \\
\hline foot per year (ft/yr) & 0.3048 & meter per year $(\mathrm{m} / \mathrm{yr})$ \\
\hline cubic foot per day $\left(\mathrm{ft}^{3} / \mathrm{d}\right)$ & 0.02832 & cubic meter per day $\left(\mathrm{m}^{3} / \mathrm{d}\right)$ \\
\hline gallon per minute (gal/min) & 0.06309 & liter per second $(\mathrm{L} / \mathrm{s})$ \\
\hline \multicolumn{3}{|c|}{ Hydraulic conductivity } \\
\hline foot per day (ft/d) & 0.3048 & meter per day $(\mathrm{m} / \mathrm{d})$ \\
\hline \multicolumn{3}{|c|}{ Hydraulic gradient } \\
\hline foot per mile (ft/mi) & 0.1894 & meter per kilometer $(\mathrm{m} / \mathrm{km})$ \\
\hline \multicolumn{3}{|c|}{ Transmissivity* } \\
\hline foot squared per day $\left(\mathrm{ft}^{2} / \mathrm{d}\right)$ & 0.09290 & meter squared per day $\left(\mathrm{m}^{2} / \mathrm{d}\right)$ \\
\hline
\end{tabular}

SI to Inch/Pound

\begin{tabular}{lll}
\hline \multicolumn{1}{c}{ Multiply } & By & To obtain \\
\hline & Length & \\
\hline meter $(\mathrm{m})$ & 3.281 & foot $(\mathrm{ft})$ \\
\hline & Flow rate & \\
\hline cubic meter per day $\left(\mathrm{m}^{3} / \mathrm{d}\right)$ & 35.31 & cubic foot per day $\left(\mathrm{ft}^{3} / \mathrm{d}\right)$ \\
\hline
\end{tabular}

Temperature in degrees Celsius $\left({ }^{\circ} \mathrm{C}\right)$ may be converted to degrees Fahrenheit $\left({ }^{\circ} \mathrm{F}\right)$ as follows:

${ }^{\circ} \mathrm{F}=\left(1.8 \times^{\circ} \mathrm{C}\right)+32$

Temperature in degrees Fahreheit $\left({ }^{\circ} \mathrm{F}\right)$ may be converted to degrees Celsius $\left({ }^{\circ} \mathrm{C}\right)$ as follows:

${ }^{\circ} \mathrm{C}=\left({ }^{\circ} \mathrm{F}-32\right) / 1.8$

Vertical coordinate information is referenced to the North American Vertical Datum of 1988 (NAVD 88).

Horizontal coordinate information is referenced to the North American Datum of 1983 (NAD 83).

Altitude, as used in this report, refers to distance above the vertical datum.

*Transmissivity: The standard unit for transmissivity is cubic foot per day per square foot times foot of aquifer thickness $\left[\left(\mathrm{ft}^{3} / \mathrm{d}\right) / \mathrm{ft}^{2}\right] \mathrm{ft}$. In this report, the mathematically reduced form, foot squared per day $\left(\mathrm{ft}^{2} / \mathrm{d}\right)$, is used for convenience. 


\title{
Steady-State Numerical Groundwater Flow Model of the Great Basin Carbonate and Alluvial Aquifer System
}

\author{
By Lynette E. Brooks, Melissa D. Masbruch, Donald S. Sweetkind, and Susan G. Buto
}

\section{Abstract}

This report describes the construction, calibration, evaluation, and results of a steady-state numerical groundwater flow model of the Great Basin carbonate and alluvial aquifer system that was developed as part of the U.S. Geological Survey National Water Census Initiative to evaluate the nation's groundwater availability. The study area spans 110,000 square miles across five states. The numerical model uses MODFLOW-2005, and incorporates and tests complex hydrogeologic and hydrologic elements of a conceptual understanding of an interconnected groundwater system throughout the region, including mountains, basins, consolidated rocks, and basin fill. The level of discretization in this model has not been previously available throughout the study area.

Observations used to calibrate the model are those of water levels and discharge to evapotranspiration, springs, rivers, and lakes. Composite scaled sensitivities indicate the simulated values of discharge to springs, rivers, and lakes provide as much information about model parameters as do simulated water-level values. The model has 176 parameters and little parameter correlation. The simulated equivalents to observations provide enough information to constrain most parameters to smaller ranges than the conceptual constraints, and most parameter values are within reasonable ranges.

Model fit to observations, comparison of simulated to conceptual water-level contours, and comparison of simulated to conceptual water budgets indicate this model provides a reasonable representation of the regional groundwater system. Eighty-six percent of the simulated values of water levels in wells are within 119 feet (one standard deviation of the error) of the observed values. Ninety percent of the simulated discharges are within 30 percent of the observed values. Total simulated recharge in the study area is within 10 percent of the conceptual amount; total simulated discharge is the same as conceptual discharge. Comparison of simulated hydraulic heads with the conceptual potentiometric surface indicates that the model accurately depicts major features of the hydraulichead distribution. The incorporation of new recharge estimates and of mountain springs and streams as model observations creates higher simulated recharge mounds under many mountain ranges and highlights that in many cases, the regional flow paths go around, not through (or under) mountain ranges. Results from the model show that much of the flow in the groundwater system occurs in deeper layers, even though about 86 percent of the discharge occurs in layer 1. Over 95 percent of the recharge moves down from layer 1 , and about 25 percent moves down to layer 8 .

The model was used to delineate six simulated groundwater flow regions that connect recharge areas to discharge areas. The eastern Great Salt Lake and Great Salt Lake Desert model regions contain 75 percent of the groundwater budget, but only 42 percent of the study area. In contrast, the more southern Death Valley and Colorado model regions contain only 12 percent of the groundwater budget, but 37 percent of the study area.

Examples of potential use of the model to investigate the groundwater system include (1) the effects of different recharge, (2) different interpretations of the extent or offset of long faults or fault zones, and (3) different conceptual models of the spatial variation of hydraulic properties. The model can also be used to examine the ultimate effects of groundwater withdrawals on a regional scale, to provide boundary conditions for local-scale models, and to guide data collection.

\section{Introduction}

The numerical groundwater flow model described in this report was developed as part of the U.S. Geological Survey (USGS) National Water Census Initiative to evaluate the nation's groundwater availability. The model simulates the complex hydrogeologic system of the Great Basin carbonate and alluvial aquifer system (GBCAAS). The GBCAAS is located in the Basin and Range physiographic province and spans a large, topographically, geologically, and climatologically diverse region that covers 110,000 square miles $\left(\mathrm{mi}^{2}\right)$ across five states; most of the study area is in western Utah and eastern Nevada (fig. 1). The area simulated with the numerical groundwater flow model generally includes or extends beyond, the region modeled in a previous hydrogeologic study of the eastern Great Basin carbonate-rock province (GB/CRP) conducted during 1981-87 as part of the USGS Regional Aquifer-System Analysis (RASA) program (fig. 2; Prudic and others, 1995). 


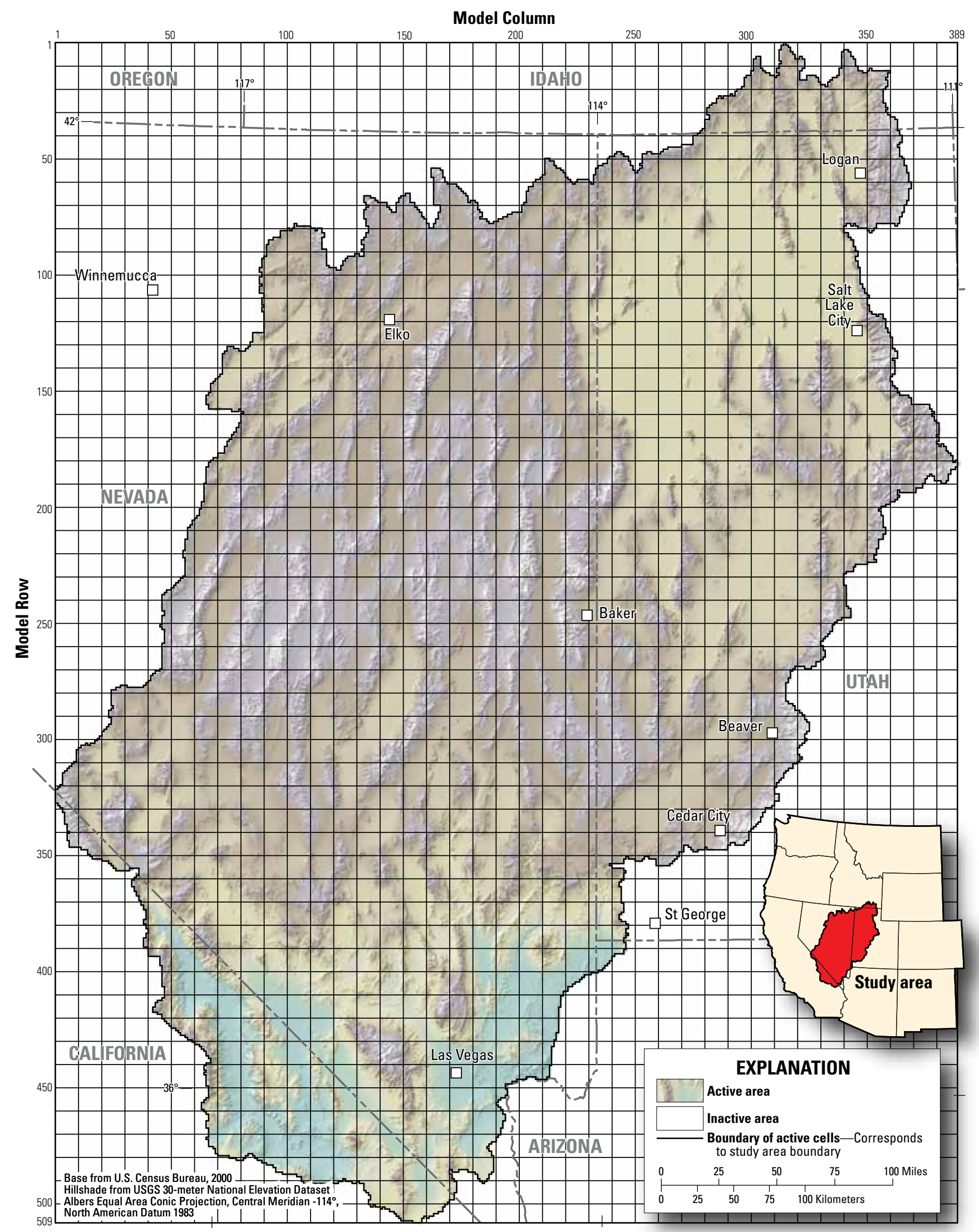

Figure 1. Location of the model grid for the numerical groundwater flow model of the Great Basin carbonate and alluvial aquifer system. 


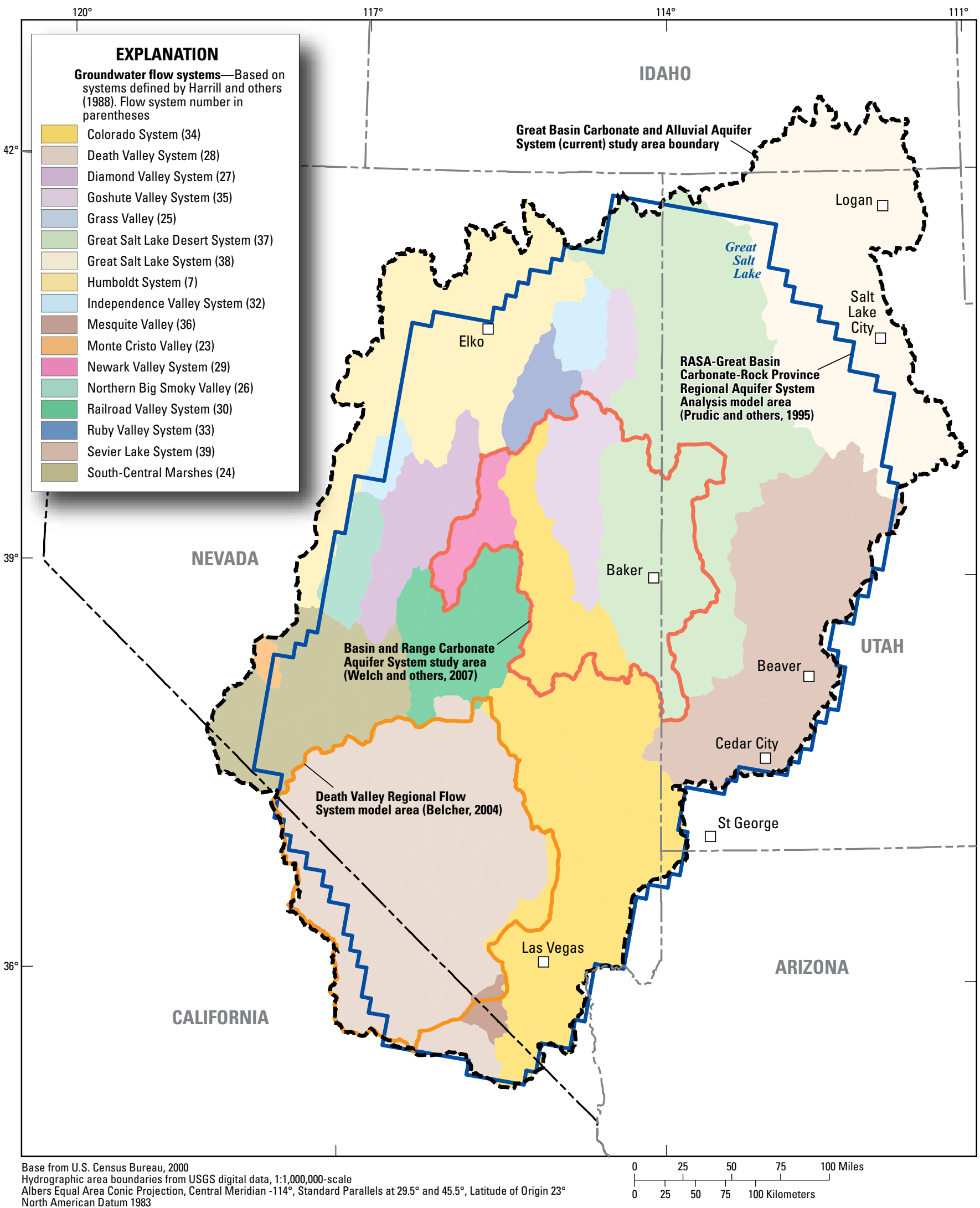

Figure 2. Location of groundwater flow systems, selected previous regional groundwater studies, and regional model areas within the Great Basin carbonate and alluvial aquifer system study area. 
The groundwater flow model was developed to represent steady-state conditions that existed before extensive groundwater development. Surface-water development started in the $1800 \mathrm{~s}$, but in much of the area groundwater development occurred well after the 1940s, and collection of enough hydrologic data on which to base a numerical model did not occur until the 1940 s to 1960 s. The model can be considered to represent conditions in the 1940 s throughout the entire study area, to represent conditions into the 1960 s over much of the area, and to represent more recent time, including current-day conditions, in areas with limited groundwater development. This numerical model represents the groundwater system conditions with surface-water development and irrigation with surface water, but limited groundwater development.

The numerical model incorporates and tests hydrogeologic and hydrologic elements of the conceptual model presented in Heilweil and Brooks (2011). That conceptualization was of an interconnected groundwater system throughout the region, including mountains, basins, consolidated rocks, and basin fill. The report of Heilweil and Brooks (2011) included a comprehensive summary and compilation of hydrologic data for the entire GBCAAS study area, a new regional digital hydrogeologic framework, a regional potentiometricsurface map for the entire study area, and groundwater budget estimates compiled for 165 individual hydrographic areas (HAs; pl. 1) and 17 regional groundwater flow systems (fig. 2; Heilweil and Brooks, 2011). In discussing the National Water Census program summarizing groundwater availability on regional scales across the United States, Reilly and others (2008) emphasized that numerical simulations of groundwater systems were built upon underlying conceptual models of how the groundwater system functions. In that sense, the conceptual model presented in Heilweil and Brooks (2011) forms the basis of the GBCAAS numerical flow model presented in this report and is considered a companion report. Evaluation of the model compares simulated budgets to those presented by Masbruch and others (2011) for each of the 17 flow systems in the model area and by Masbruch (2011a and 2011b) for each HA in the model area. This report, including tables and figures, includes the HA or groundwater flow system number in parentheses after the name for consistency with Heilweil and Brooks (2011).

\section{Purpose and Scope}

The purpose of this report is to describe the construction, calibration, evaluation, and results of a steady-state numerical groundwater flow model of the GBCAAS study area. One purpose of the model is to test whether the groundwater budget and flow directions conceptualized for the study area (Heilweil and Brooks, 2011) can be simulated using reasonable model parameter values while providing an appropriate match to observed groundwater levels and discharges. A broader purpose of the model is to assess regional groundwater resources in the context of the complete groundwater budget, and to allow for the assessment of changes in groundwater availability at a regional scale. The model addresses the following objectives of the national groundwater availability assessments as listed by Reilly and others (2008): (1) development of water budgets, (2) tools to provide a regional context for groundwater availability and future projections of groundwater availability, (3) regional estimates of aquifer properties, (4) evaluation of existing groundwater monitoring networks, and (5) new approaches for regional groundwater analysis.

The model presented in this report represents steady-state groundwater conditions before groundwater development, incorporates the climatic diversity and geologic complexity of the study area, and can be used as the basis for more detailed or transient models. Data used to construct and calibrate this model are limited to information in U.S. Geological Survey databases before 2008, reports published before 2009 with the exception of Heilweil and Brooks (2011), and personal communications before 2009. Continuously updating the model files and report for new information from several concurrent studies was beyond the scope of this project.

\section{Previous Studies}

Numerous previous studies have been conducted within the GBCAAS study area at a variety of scales by the USGS, the states of Utah and Nevada, other government agencies, and consultants. Most of these studies concentrated on one basin or HA, and often emphasized the basin fill instead of the entire groundwater system. These studies are too numerous to list here, but many are listed in Heilweil and Brooks (2011, Auxiliaries 2 and 3); they are referenced in this report where specifically used.

Only one previous study included all of the current study area. During the 1980s, the USGS RASA program assessed the nation's major aquifer systems. As part of this effort, Harrill and Prudic (1998) delineated major alluvial and consolidated-rock aquifer systems in the Great Basin and evaluated regional flow in the carbonate-rock province of the Great Basin. The Great Basin RASA study included hydrogeology (Plume and Carlton, 1988), geochemistry (Thomas and others, 1996), and hydrology (Thomas and others, 1986; Harrill and others, 1988) over an area that includes the present study area plus most of the rest of western Nevada (Heilweil and others, 2011, fig. A-2). The results of the RASA studies form the basis of most subsequent conceptualizations of groundwater flow in the Great Basin.

The Great Basin RASA study included a numerical groundwater flow model (Prudic and others, 1995) for the carbonate-rock dominated eastern part of the Great Basin, a large geographic area that encompasses much of the GBCAAS study area (fig. 2). Prudic and others (1995) provided comparisons between simulated and conceptual groundwater flow systems and between simulated and observed discharge to selected large springs. Because the model developed by Prudic and others (1995) incorporates most of the current study area, comparisons between the two models are included in this report. As part of that comparison, simulated budgets from both models are compared in the RASA model regions. 
Several other studies include large areas of the current study area, but are considered subregional. A groundwater study of the Death Valley regional groundwater flow system (DVRFS; fig. 2) was completed by the USGS in support of U.S. Department of Energy (DOE) programs (Belcher, 2004; Belcher and Sweetkind, 2010). The study updated estimates of discharge and integrated all available information in the region to develop a numerical three-dimensional transient groundwater flow model of the Death Valley region. The DVRFS study provided an improved understanding of regional groundwater flow in southern Nevada and the Death Valley region in California. The discharge to springs and evapotranspiration presented in Belcher (2004) are used as observations in this report. Faunt and others (2004) provided comparisons between simulated and estimated interbasin flow and between simulated and observed discharge to springs and evapotranspiration. Comparisons between the DVRFS model and the GBCAAS model are included in this report.

Another subregional investigation, which did not include a numerical flow model, is the Basin and Range carbonate-rock aquifer system (BARCAS) study completed by the USGS and the Desert Research Institute (Welch and others, 2007). The BARCAS study developed potentiometric-surface maps showing groundwater flow directions in both alluvial and carbonate aquifers (Wilson, 2007), derived new groundwater budget estimates, and assessed interbasin groundwater flow using a combination of basin-boundary geology, groundwaterlevel data, and geochemistry. Many of the estimates used for groundwater discharge by evapotranspiration in this report are from Welch and others (2007).

Several subregional hydrogeologic and hydrologic studies of eastern Nevada have been completed as part of waterrights applications associated with proposed groundwater development by regional water agencies in southern Nevada (Dixon and others, 2007; Southern Nevada Water Authority and U.S. Bureau of Land Management, 2008; Rowley and others, 2009). Certain geologic cross sections developed for these studies were used as input to the digital hydrogeologic framework of the GBCAAS study area (Cederberg and others, 2011).

\section{Description of Study Area}

The study area is characterized by north or northeast trending mountain ranges separated by broad basins (fig. 1). Mountain ranges are 5 to 15 miles (mi) wide and can be as long as $50 \mathrm{mi}$ or more. Basins typically are 5 to $10 \mathrm{mi}$ wide and 35 to $70 \mathrm{mi}$ long, although some are as long as $150 \mathrm{mi}$. Topographic relief between the mountain crests and basin floors typically ranges from 1,000 to 6,000 feet (ft), with a few areas exceeding $8,000 \mathrm{ft}$. The altitude of the basin floor is below sea level in Death Valley, but ranges from about 2,500 to 6,000 ft above sea level elsewhere. Mountain altitudes commonly range from 8,000 to $11,000 \mathrm{ft}$, with a few peaks exceeding $13,000 \mathrm{ft}$ (Heilweil and others, 2011).
Most of the study area can be categorized as having a semi-arid or steppe climate (Strahler, 1989), but valleys in the extreme southwestern part of the study area have an arid desert climate, and mountains in the extreme northeastern part have an alpine climate. Annual precipitation ranges from $1.5 \mathrm{in}$. on valley floors in southern Nevada and eastern California to $70 \mathrm{in}$. in the mountain uplands of northern Utah (Daly and others, 2004; 2008). Most of the precipitation falls during the winter as snow in the mountains and is associated with storms originating in the Pacific Ocean, although substantial rainfall also can occur in late summer and early autumn, coincidental with monsoonal moisture that moves northward from the Gulf of Mexico and Gulf of California (Brenner, 1974; Weng and Jackson, 1999). This monsoonal rainfall is more pronounced in the southern part of the study area.

Because of the generally semi-arid climate within the GBCAAS study area, surface-water resources are limited and unevenly distributed across the area (Heilweil and others, 2011, p. 9). The Bear, Weber, and Provo Rivers are three of the larger rivers; they originate in mountains east of the study area and flow westward through the Wasatch Range into the study area. Canals and aqueducts (transbasin diversions) also bring surface water through the Wasatch Range into the study area. In Nevada, tributaries to the Humboldt River are fed predominantly by snowmelt that runs off various mountain ranges in the north-central part of the state (Heilweil and others, 2011, p. 9).

The GBCAAS study area is experiencing rapid population growth (U.S. Census Bureau, 2005) and has some of the highest per capita water use in the United States (Bergquist, 1994), resulting in increased demand for groundwater. Growing urban areas include Las Vegas, Nevada, and the area from Logan to Cedar City, Utah, along the eastern edge of the study area (fig. 1). Much of the rest of the study area is sparsely populated and is largely undeveloped.

\section{Groundwater Hydrology}

The groundwater system in the study area consists of water in unconsolidated deposits in the basins, in consolidated rock underlying the basins, and in the adjacent mountain blocks. The consolidated-rock and basin-fill aquifers typically are well-connected hydraulically (Gardner and others, 2011; Sweetkind and others, 2011b), with most of the recharge occurring in the consolidated-rock mountain blocks and most of the discharge occurring from the lower-altitude basinfill deposits. Groundwater movement within the study area typically occurs from recharge areas in the mountains to lower-altitude discharge areas. Groundwater generally follows topography, creating a broad pattern of flow from mountainous areas to the Great Salt Lake Desert, the Humboldt River, the Colorado River, and Death Valley (pl. 1; Heilweil and Brooks, 2011, pl. 2). It is assumed that downward vertical gradients typically exist beneath recharge areas in the mountain blocks or along the valley margins, and that upward vertical gradients exist in valley-bottom discharge areas (Sweetkind and others, 2011b, p. 53). 
The potentiometric-surface map of Heilweil and Brooks (2011, pl. 2) illustrates groundwater mounding in highprecipitation and (or) less permeable mountain-block areas. Mounding beneath the mountains is based on supporting data within the GBCAAS study area that include water levels in wells, along with perennial stream and spring altitudes (Sweetkind and others, 2011b, p. 54). The concept of mounding is supported by earlier work, including that of Toth (1963), Fetter (1980), and Gleeson and Manning (2008).

\section{Groundwater Budget}

Groundwater budgets in the GBCAAS study area have been presented at a variety of scales. The GBCAAS study area has been subdivided into 165 individual hydrographic areas (HAs; Cardinalli and others, 1968; Rush, 1968a; Harrill and others, 1988; Harrill and Prudic, 1998; Belcher, 2004). The HAs (pl. 1) are often used by state agencies as the basis for water-resource management, are based primarily on surfacewater divides, and range in size from 12 to 4,648 $\mathrm{mi}^{2}$ (Heilweil and Buto, 2011). The HAs have been grouped into 17 regional groundwater flow systems (fig. 2; Harrill and others, 1988; Belcher, 2004) primarily on the basis of the hydraulic gradient, the permeability of basin fill and consolidated rock, and the location of terminal discharge areas (Harrill and others, 1988). The regional groundwater flow systems (fig. 2) range in size from 282 to $18,849 \mathrm{mi}^{2}$ (table 1). Groundwater flow system boundaries primarily follow surface-water divides. Groundwater flow occurs between HAs and between groundwater flow systems (Winograd and Pearson, 1976; Harrill and others, 1988; Belcher, 2004; Welch and others, 2007; Belcher and others, 2009). Masbruch (2011a; 2011b) presents groundwater budgets for the 165 HAs and Masbruch and others (2011) present groundwater budgets for the 17 groundwater flow systems (tables 1 and 2). References to HAs and to groundwater flow systems in this report use both the name and the number associated with the HA or groundwater flow system.

The majority of groundwater recharge within the study area occurs as in-place recharge in the mountain ranges as direct infiltration of precipitation. The majority of discharge within the study area and in 15 of the groundwater flow systems occurs as evapotranspiration of groundwater (ETg). In the Colorado groundwater flow system (34), the majority of discharge is to springs; in the Great Salt Lake groundwater flow system (38), the majority of discharge is to basin-fill rivers, lakes, and reservoirs.

\section{Hydrogeologic Framework}

Aquifer geometry and structural features are integral to the simulation of groundwater flow in the GBCAAS study area. Structural disruption has juxtaposed diverse rock types, ages, and deformational structures, creating variable and complex subsurface conditions. A three-dimensional (3D)

Table 1. Annual groundwater recharge for predevelopment conditions for each of the 17 groundwater flow systems within the Great Basin carbonate and alluvial aquifer system study area.

[Modified from Masbruch and others, 2011, table D-1. All values (except flow system area) are in acre-feet per year rounded to two significant figures. Estimated error in all values is \pm 50 percent. Groundwater flow system name: number in parentheses following name is groundwater flow system number. Abbreviations: mi ${ }^{2}$, square miles; - , no estimate]

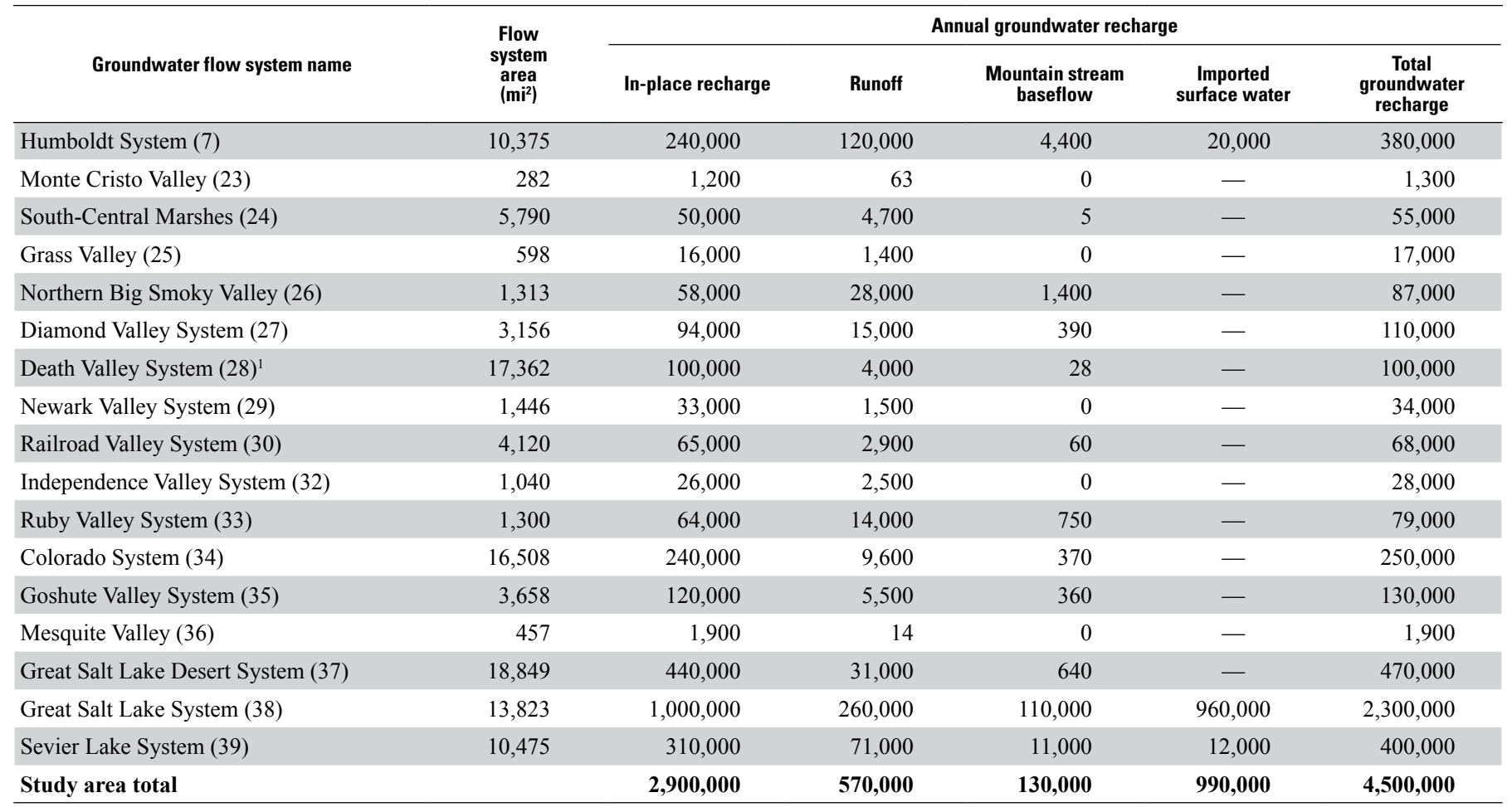

${ }^{1}$ Penoyer Valley, which Harrill and others (1988) defined as a separate groundwater flow system, is included in the Death Valley System in this report. 
hydrogeologic framework was constructed to represent the subsurface configuration of hydrogeologic units (HGUs) and major structures in the GBCAAS study area (Cederberg and others, 2011). Representative vertical sections through the 3D-hydrogeologic framework portray the modeled variability in unit thickness and altitude, and the overall complexity of the geologic system to be simulated (fig. 3). Additional cross-sectional and perspective views of the 3D-hydrogeologic framework are presented in Sweetkind and others (2011a).

Consolidated pre-Cenozoic rocks, partly consolidated to unconsolidated Cenozoic sediments, and various igneous rocks of the GBCAAS study area are grouped into HGUs that have considerable lateral extent and reasonably distinct hydrologic properties because of their physical (geological and structural) characteristics (Sweetkind and others, 2011a). HGUs representing consolidated, pre-Cenozoic rocks, in stratigraphic order from deepest to shallowest, include (1) a non-carbonate confining unit (NCCU) representing low-permeability Precambrian siliciclastic formations, and crystalline igneous and metamorphic rocks, (2) a lower carbonate aquifer unit (LCAU) representing high-permeability Cambrian through Devonian limestone and dolomite, (3) an upper siliciclastic confining unit (USCU) representing low-permeability Mississippian shale, and (4) an upper carbonate aquifer unit (UCAU) representing high-permeability Pennsylvanian and Permian carbonate rocks. For computational reasons in the construction of the framework, separate HGUs must be defined where the stratigraphic section is duplicated by largeoffset thrust faults (Sweetkind and others, 2011a). In these situations, a thrusted non-carbonate confining unit (TNCCU) and a thrusted lower carbonate aquifer unit (TLCAU) are defined, representing low-permeability siliciclastic rocks and high-permeability limestone and dolomite, respectively. HGUs representing Cenozoic basin-fill and volcanic rocks include a volcanic unit (VU) representing outcrop areas of volcanic rocks, a lower basin-fill aquifer unit (LBFAU) representing the lower one-third of the Cenozoic basin fill, and an upper basinfill aquifer unit (UBFAU) representing the upper two-thirds of the Cenozoic basin fill.

Relative differences in hydraulic properties were used to differentiate aquifers from confining or semi-confining HGUs in the study area (table 3 ). These evaluations primarily were based on relative differences in permeability determined from HGU material properties or on previous estimates of hydraulic conductivity. Sweetkind and others (2011a, table B-1) present estimates of hydraulic properties that were compiled from aquifer tests in the DVRFS, which are considered representative of hydraulic properties over much of the GBCAAS study area because of similar rock types and HGUs. More detail for the hydraulic properties is given in Belcher and others (2002, table 1), which allows calculation of standard deviation of the hydraulic conductivity (table 3 ). Igneous, metamorphic, and

Table 2. Annual groundwater discharge for predevelopment conditions for each of the 17 groundwater flow systems within the Great Basin carbonate and alluvial aquifer system study area.

[Modified from Masbruch and others, 2011, table D-2. All values (except flow system area) are in acre-feet per year rounded to two significant figures. Estimated error in all values is \pm 30 percent. Groundwater flow system name: number in parentheses following name is groundwater flow system number. Abbreviations: mi ${ }^{2}$, square miles; ETg, groundwater evapotranspiration]

\begin{tabular}{|c|c|c|c|c|c|c|c|}
\hline \multirow[b]{2}{*}{ Groundwater flow system name } & \multirow[b]{2}{*}{$\begin{array}{l}\text { Flow } \\
\text { system } \\
\text { area } \\
\left(\mathrm{mi}^{2}\right)\end{array}$} & \multicolumn{6}{|c|}{ Annual groundwater discharge } \\
\hline & & ETg & $\begin{array}{c}\text { Mountain } \\
\text { streams }\end{array}$ & $\begin{array}{l}\text { Basin-fill } \\
\text { streams/lakes/ } \\
\text { reservoirs }\end{array}$ & Springs & $\begin{array}{c}\text { Adjustment to } \\
\text { natural discharge } \\
\text { for well } \\
\text { withdrawals }\end{array}$ & $\begin{array}{c}\text { Total } \\
\text { groundwater } \\
\text { discharge }\end{array}$ \\
\hline Humboldt System (7) & 10,375 & 240,000 & 15,000 & 14,000 & 28,000 & 600 & 300,000 \\
\hline Monte Cristo Valley (23) & 282 & 400 & 0 & 0 & 0 & 0 & 400 \\
\hline South-Central Marshes (24) & 5,790 & 58,000 & 46 & 0 & 4,800 & 0 & 63,000 \\
\hline Northern Big Smoky Valley (26) & 1,313 & 62,000 & 4,700 & 0 & 2,300 & 0 & 69,000 \\
\hline Diamond Valley System (27) & 3,156 & 44,000 & 1,500 & 0 & 12,000 & 0 & 58,000 \\
\hline Death Valley System $(28)^{1}$ & 17,362 & 66,000 & 280 & 61 & 35,000 & 0 & 100,000 \\
\hline Newark Valley System (29) & 1,446 & 22,000 & 0 & 0 & 9,700 & 0 & 32,000 \\
\hline Railroad Valley System (30) & 4,120 & 65,000 & 600 & 300 & 32,000 & 0 & 98,000 \\
\hline Goshute Valley System (35) & 3,658 & 83,000 & 3,600 & 0 & 45,000 & 0 & 130,000 \\
\hline Mesquite Valley (36) & 457 & 2,200 & 0 & 0 & 0 & 0 & 2,200 \\
\hline Great Salt Lake Desert System (37) & 18,849 & 330,000 & 4,500 & 0 & 110,000 & 1,600 & 450,000 \\
\hline Great Salt Lake System (38) & 13,823 & 430,000 & 370,000 & 570,000 & 520,000 & 260,000 & $2,200,000$ \\
\hline Sevier Lake System (39) & 10,475 & 210,000 & 40,000 & 37,000 & 47,000 & 71,000 & 400,000 \\
\hline Study area total & & $1,800,000$ & 450,000 & 660,000 & 990,000 & 330,000 & $4,200,000$ \\
\hline
\end{tabular}

${ }^{1}$ Penoyer Valley, which Harrill and others (1988) defined as a separate groundwater flow system, is included in the Death Valley System in this report. 


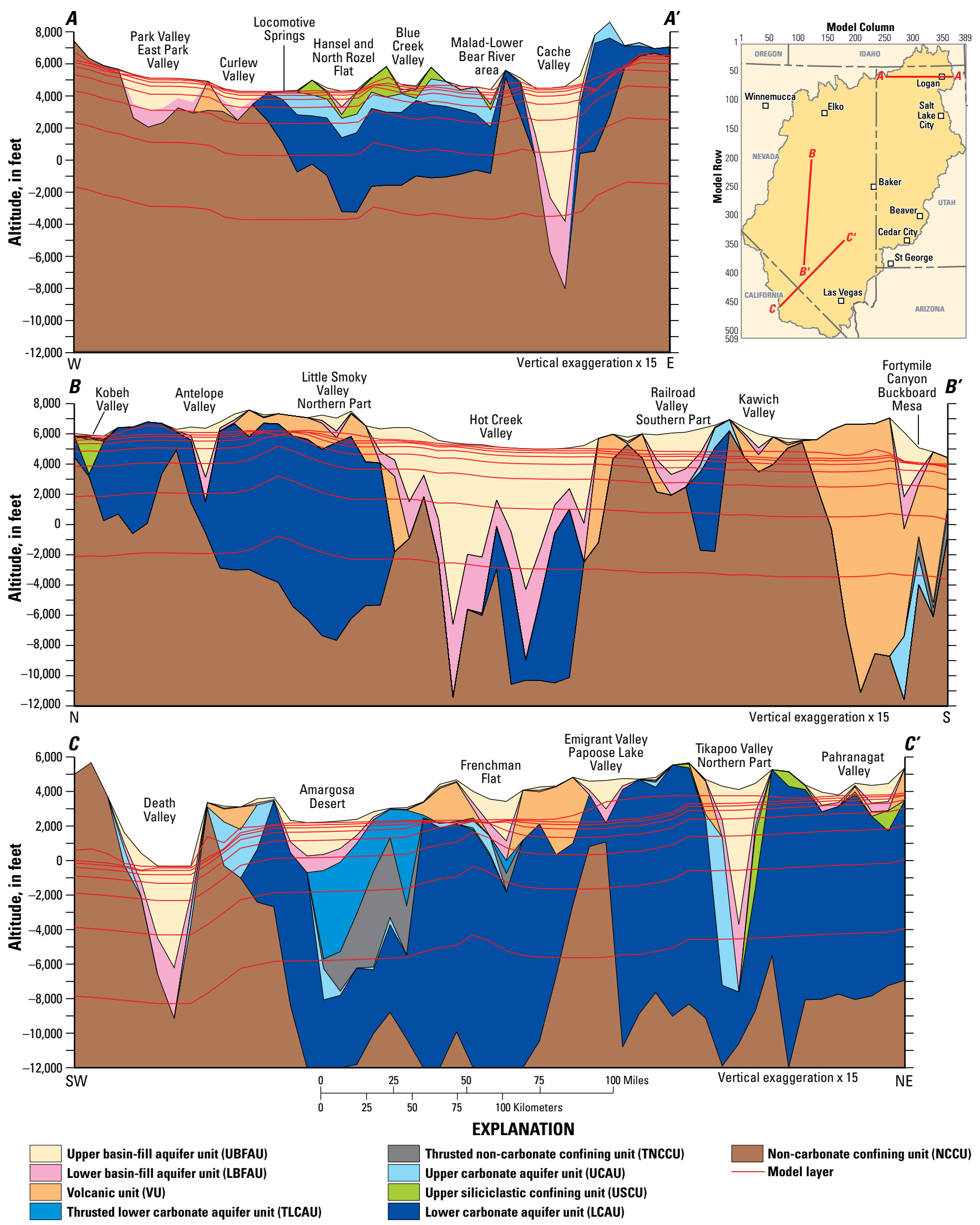

Figure 3. Cross sections showing hydrogeologic units and model layers in the numerical groundwater flow model, Great Basin carbonate and alluvial aquifer system study area. 
Table 3. Horizontal hydraulic-conductivity estimates of hydrogeologic units in the Death Valley regional groundwater flow system and the Great Basin carbonate and alluvial aquifer system study area.

[Modified from Belcher and others, 2002, table 1. Geometric mean and standard deviation are back-transformed from logarithmic values. Abbreviations: GBCAAS, Great Basin carbonate and alluvial aquifer system; DVRFS, Death Valley regional groundwater flow system; Hydrogeologic unit acronyms for Great Basin carbonate and alluvial aquifer system; UBFAU, upper basin-fill aquifer unit; LBFAU, lower basin-fill aquifer unit; VU, volcanic unit; UCAU, upper carbonate aquifer unit; LCAU, lower carbonate aquifer unit; TLCAU, thrusted lower carbonate aquifer unit; USCU, upper siliciclastic confining unit; NCCU, non-carbonate confining unit; TNCCU, thrusted non-carbonate confining unit. Hydrogeologic unit acronyms for Death Valley regional groundwater flow system: AA, alluvial aquifer; ACU, alluvial confining unit; YVU, younger volcanic rocks unit; VSU, volcaniclastic and sedimentary rocks unit; TV, Tertiary volcanic rocks; OVU, older volcanic rocks unit; UCA, upper carbonate aquifer; LCA, lower carbonate aquifer; UCCU, upper clastic confining unit; LCCU, lower clastic confining unit]

\begin{tabular}{|c|c|c|c|c|c|c|c|c|c|}
\hline \multirow{3}{*}{ GBCAAS hydrogeologic unit } & \multirow{3}{*}{$\begin{array}{l}\text { DVRFS } \\
\text { hydrogeologic } \\
\text { unit or subunit }\end{array}$} & \multicolumn{8}{|c|}{ Hydraulic conductivity (feet per day) } \\
\hline & & \multirow{2}{*}{$\begin{array}{l}\text { Geometric } \\
\text { mean }\end{array}$} & \multirow{2}{*}{$\begin{array}{l}\text { Arithmetic } \\
\text { mean }\end{array}$} & \multirow[t]{2}{*}{ Minimum } & \multirow[t]{2}{*}{ Maximum } & \multicolumn{2}{|c|}{$\begin{array}{l}\text { 95-percent confidence interval } \\
\text { (reasonable range) }\end{array}$} & \multirow{2}{*}{$\begin{array}{c}\text { Number of } \\
\text { measure- } \\
\text { ments }\end{array}$} & \multirow{2}{*}{$\begin{array}{c}\text { Standard } \\
\text { deviation of } \\
\text { log values }\end{array}$} \\
\hline & & & & & & Low & High & & \\
\hline UBFAU, non-playa & AA & 4.9 & 35 & 0.0002 & 430 & 0.02 & 1,400 & 52 & 1.3 \\
\hline UBFAU, playa & $\mathrm{ACU}$ & 9.8 & 34 & 0.01 & 110 & 0.07 & 1,500 & 15 & 1.1 \\
\hline LBFAU & YVU/VSU & 0.2 & 4.9 & 0.0001 & 20 & 0.0002 & 260 & 15 & 1.6 \\
\hline \multirow{2}{*}{ VU } & TV & 0.4 & 13 & 0.000007 & 590 & 0.0007 & 260 & 170 & 1.4 \\
\hline & OVU & 0.01 & 0.2 & 0.000003 & 3.3 & 0.00007 & 16 & 46 & 1.4 \\
\hline UCAU, LCAU, and TLCAU & UCA and LCA & 8.2 & 300 & 0.0003 & 2,700 & 0.003 & 25,000 & 53 & 1.8 \\
\hline USCU, NCCU, and TNCCU & $\mathrm{UCCU}$ and $\mathrm{LCCU}$ & 0.00007 & 0.7 & 0.0000001 & 16 & 0.0000000003 & 9.8 & 29 & 2.7 \\
\hline
\end{tabular}

siliciclastic rocks of the NCCU and siliciclastic rocks of the USCU typically form the least permeable HGUs within the consolidated, pre-Cenozoic rocks (table 3 ). Carbonate rocks of the LCAU and the UCAU typically form the most permeable HGUs within the pre-Cenozoic consolidated rocks. Fractured Cenozoic volcanic rocks of the VU and permeable parts of the Cenozoic basin fill within the UBFAU and the LBFAU are important local aquifers. Each of these HGUs has been subdivided into hydrogeologic zones that relate to differences in lithologic character or structural setting (Sweetkind and others, 2011a) and serve as a geologically based starting point for spatially distributing hydraulic conductivity within the numerical model.

The two lowest HGUs (NCCU and LCAU) are extensive and thick within the study area. The NCCU is present throughout most of the model domain (fig. 4) as the deepest HGU and generally has low to moderate permeability (Sweetkind and others, 2011a, p. 19). The NCCU was divided into three hydrogeologic zones (fig. A4-1; table A4-1) by Sweetkind and others (2011a). The LCAU is present throughout most of the model domain (fig. 5) and generally has high permeability but locally has low permeability (Sweetkind and others, 2011a, p. 20). In some parts of the study area where the LCAU is thick and continuous (Cederberg and others, 2011, fig. A1-8), groundwater could potentially flow in the LCAU across HA boundaries (Sweetkind and others, 2011b, table C-2). The LCAU was divided into hydrogeologic zones by Sweetkind and others (2011a, fig. B-4) and structural areas of potential hydrologic significance (Sweetkind and others, 2011a, fig. B-7). The intersection of these zones (fig. A4-2) creates areas of differing hydraulic properties (table A4-2).

The USCU and the UCAU HGUs are discontinuous, but locally important (figs. 6 and 7). The USCU generally has low permeability (Sweetkind and others, 2011a, p. 22); the UCAU generally has moderate to high permeability, but has lower permeability in the western part of the study area (Sweetkind and others, 2011a, fig. B-4). The UCAU was divided by
Sweetkind and others (2011a) into five hydrogeologic zones (fig. A4-3; table A4-2). The TNCCU and TLCAU HGUs overlie the UCAU in parts of the study area, but are less extensive than other units (figs. 8 and 9).

The VU is discontinuous throughout the study area (fig. 10) and has variable permeability (Sweetkind and others, 2011a, table B-5). The VU was divided into seven hydrogeologic zones (table A4-3) by Sweetkind and others (2011a, fig. B-4). The LBFAU and the UBFAU are areally extensive, but are discontinuous (figs. 11 and 12). In some areas, especially in Utah, the LBFAU and UBFAU are thick and continuous, and there is a high likelihood of hydraulic connection across HA boundaries in those HGUs (Sweetkind and others, 2011b, table C-2). In addition, disconnected basin-fill aquifers potentially could be connected where permeable consolidated rocks exist at interbasin divides. The LBFAU was divided into five hydrogeologic zones (fig. A4-4; table A4-3) and the UBFAU was divided into four hydrogeologic zones (fig. A4-5; table A4-3) by Sweetkind and others (2011a).

Many of the HGUs are disrupted by large-magnitude offset thrust, strike-slip, and normal faults, and by calderas (Sweetkind and others, 2011a). Juxtaposition of thick, lowpermeability rock with higher-permeability carbonate-rock aquifers by faulting or caldera emplacement commonly forms barriers to groundwater flow and is an important influence on the potentiometric surface and regional flow (Sweetkind and others, 2011b, p. 58).

Fault surfaces were not explicitly depicted within the 3D-hydrogeologic framework; instead, the effect of faulting was accomplished by inserting numerical discontinuities during the gridding of individual HGU horizons (Cederberg and others, 2011). As a result, HGUs have steep inflections and altitude changes at the fault trace but remain as continuous surfaces within the geologic framework model (Sweetkind and others, 2011a, fig. B-10). Fault zones in the GBCAAS study area (Sweetkind and others, 2011a, fig. B-8) may contain low-permeability fault cores that potentially restrict fluid flow across the fault (Caine and others, 1996). 


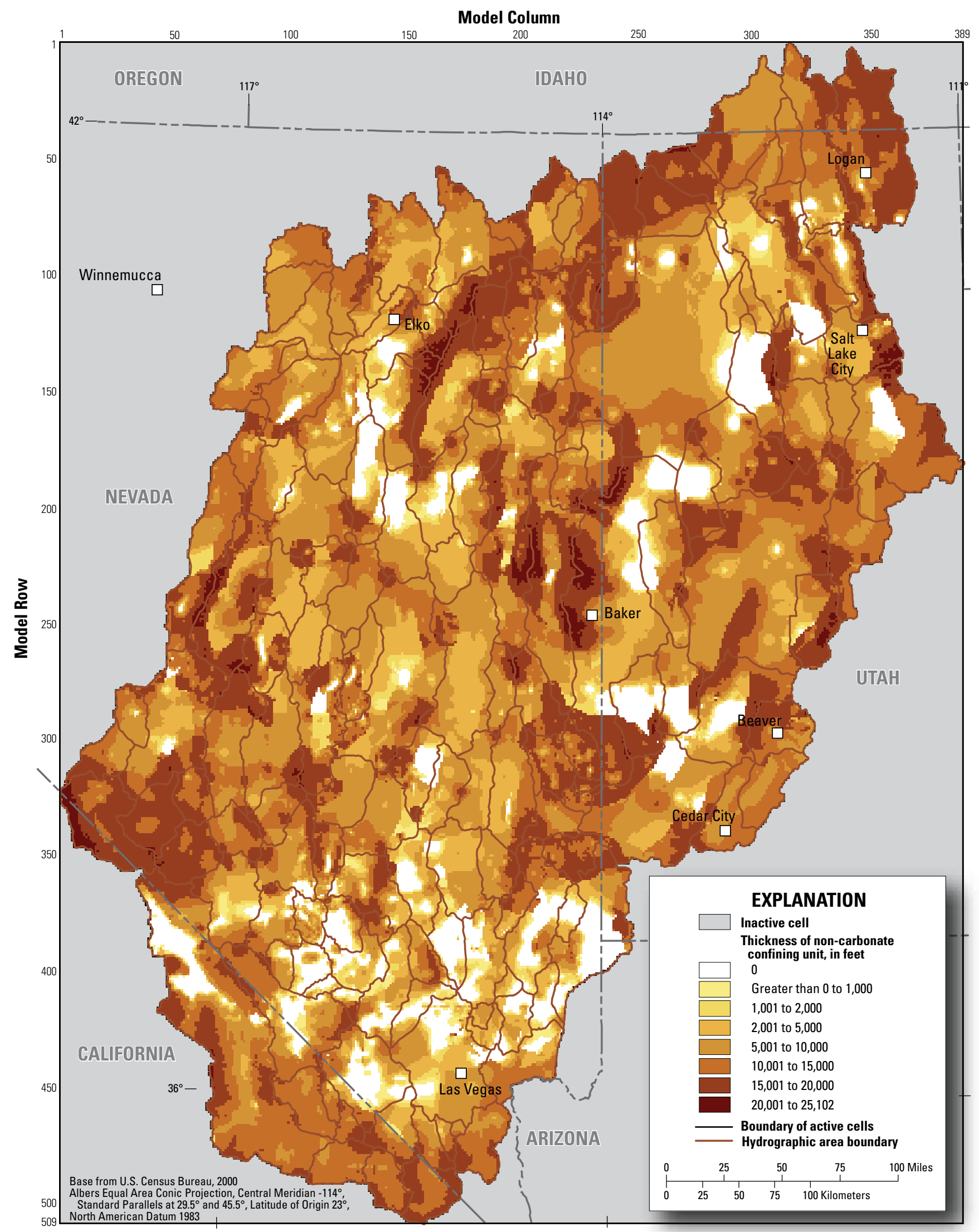

Figure 4. Thickness of the non-carbonate confining unit (NCCU) in the numerical groundwater flow model, Great Basin carbonate and alluvial aquifer system study area. 


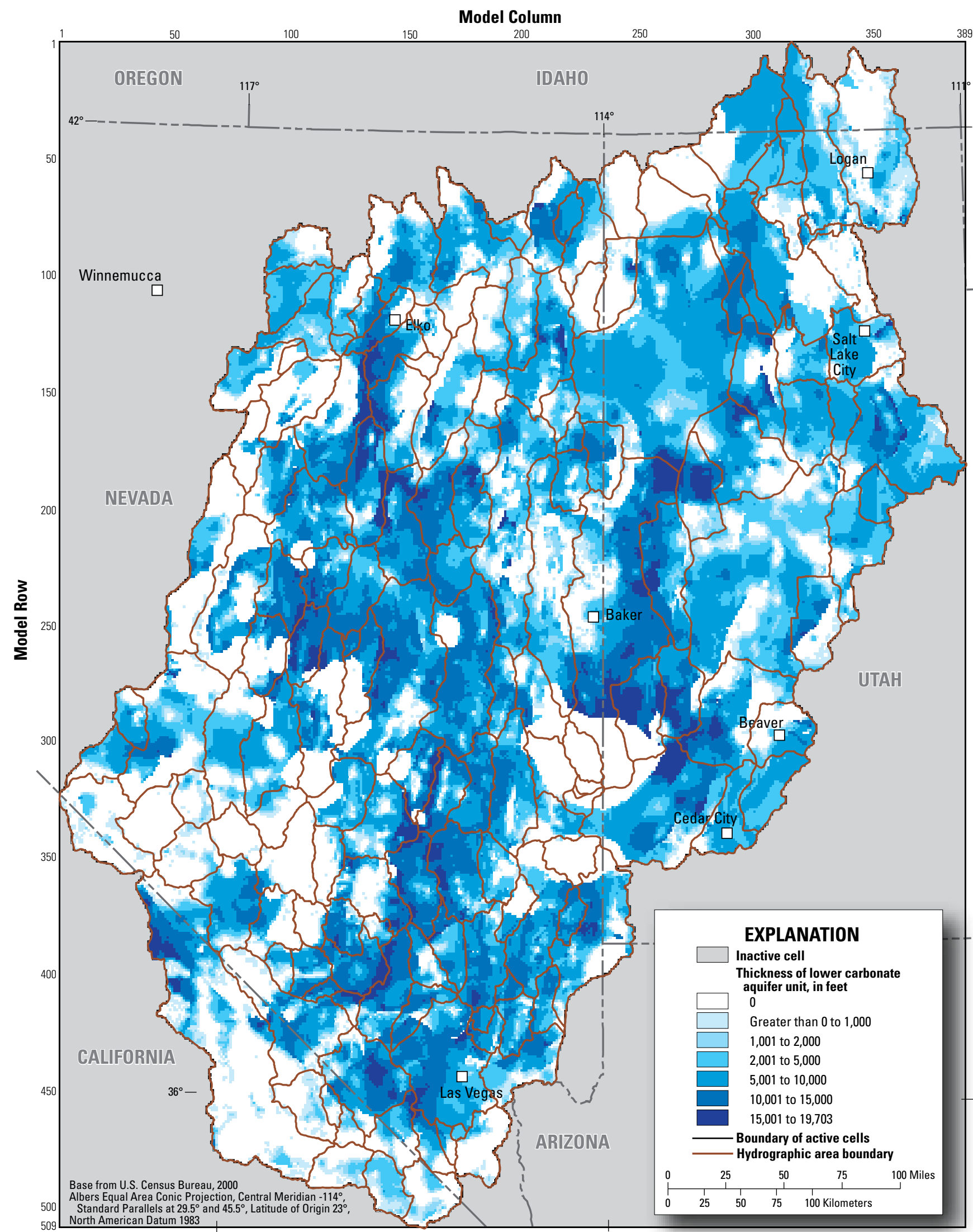

Figure 5. Thickness of the lower carbonate aquifer unit (LCAU) in the numerical groundwater flow model, Great Basin carbonate and alluvial aquifer system study area. 


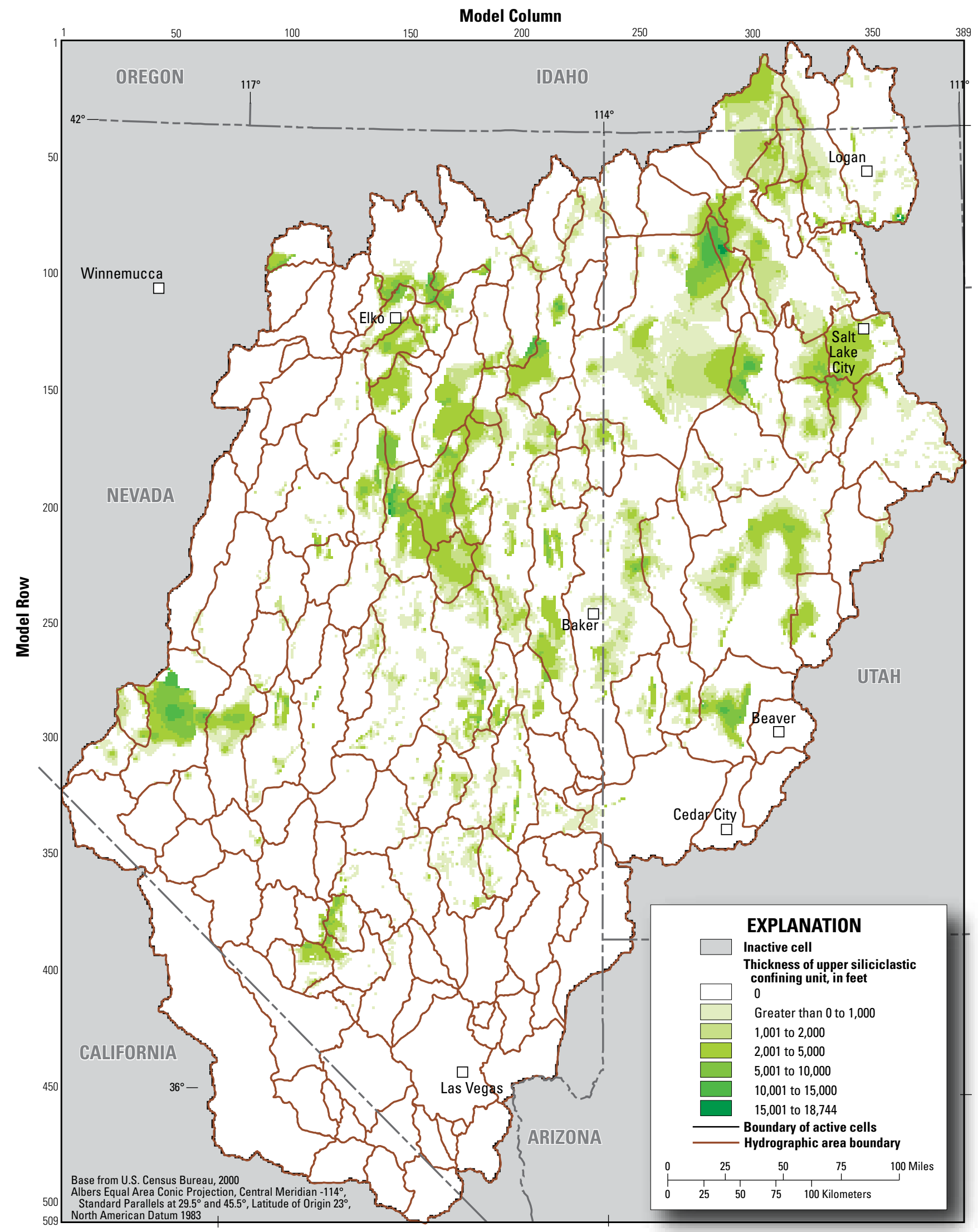

Figure 6. Thickness of the upper siliciclastic confining unit (USCU) in the numerical groundwater flow model, Great Basin carbonate and alluvial aquifer system study area. 


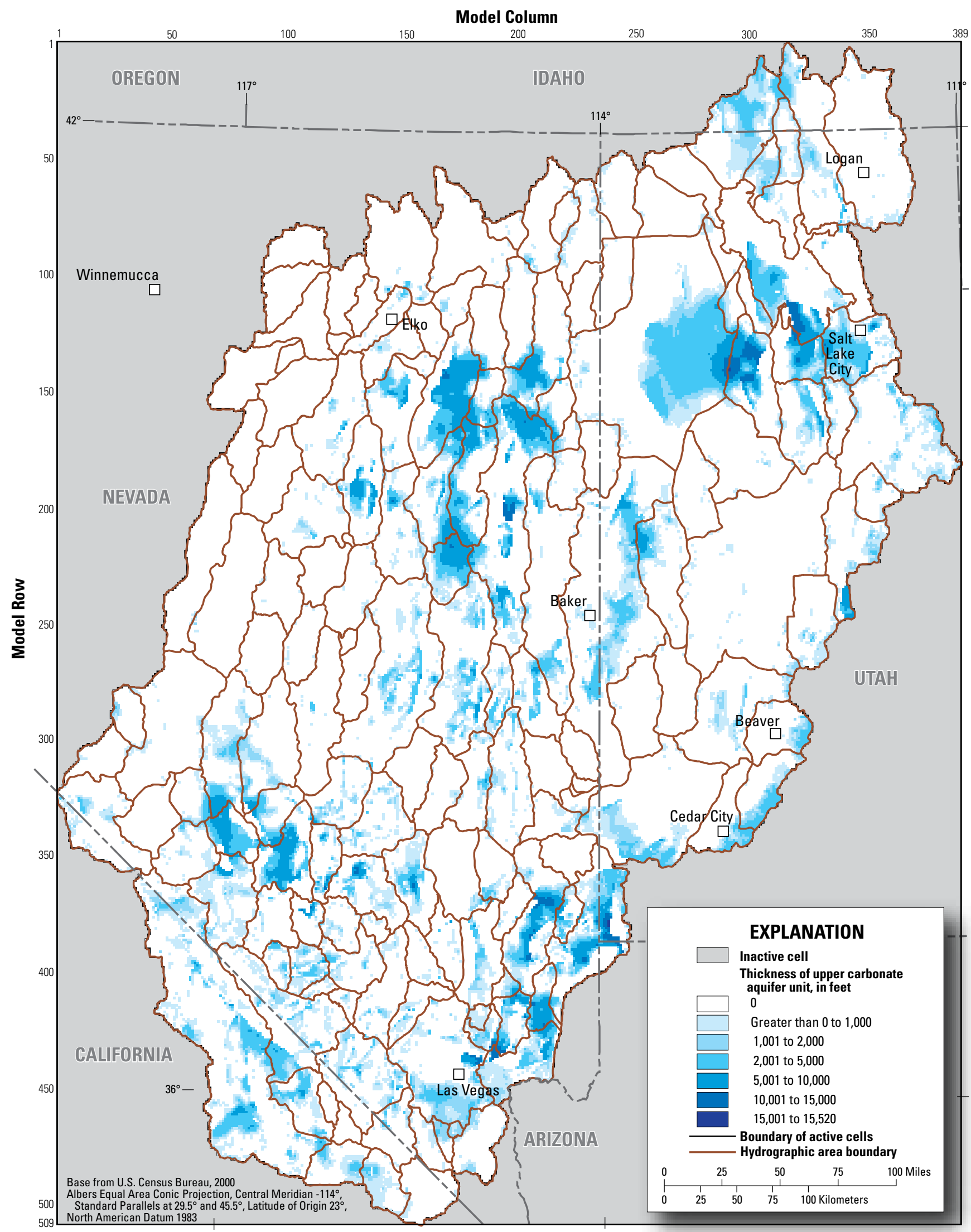

Figure 7. Thickness of the upper carbonate aquifer unit (UCAU) in the numerical groundwater flow model, Great Basin carbonate and alluvial aquifer system study area. 


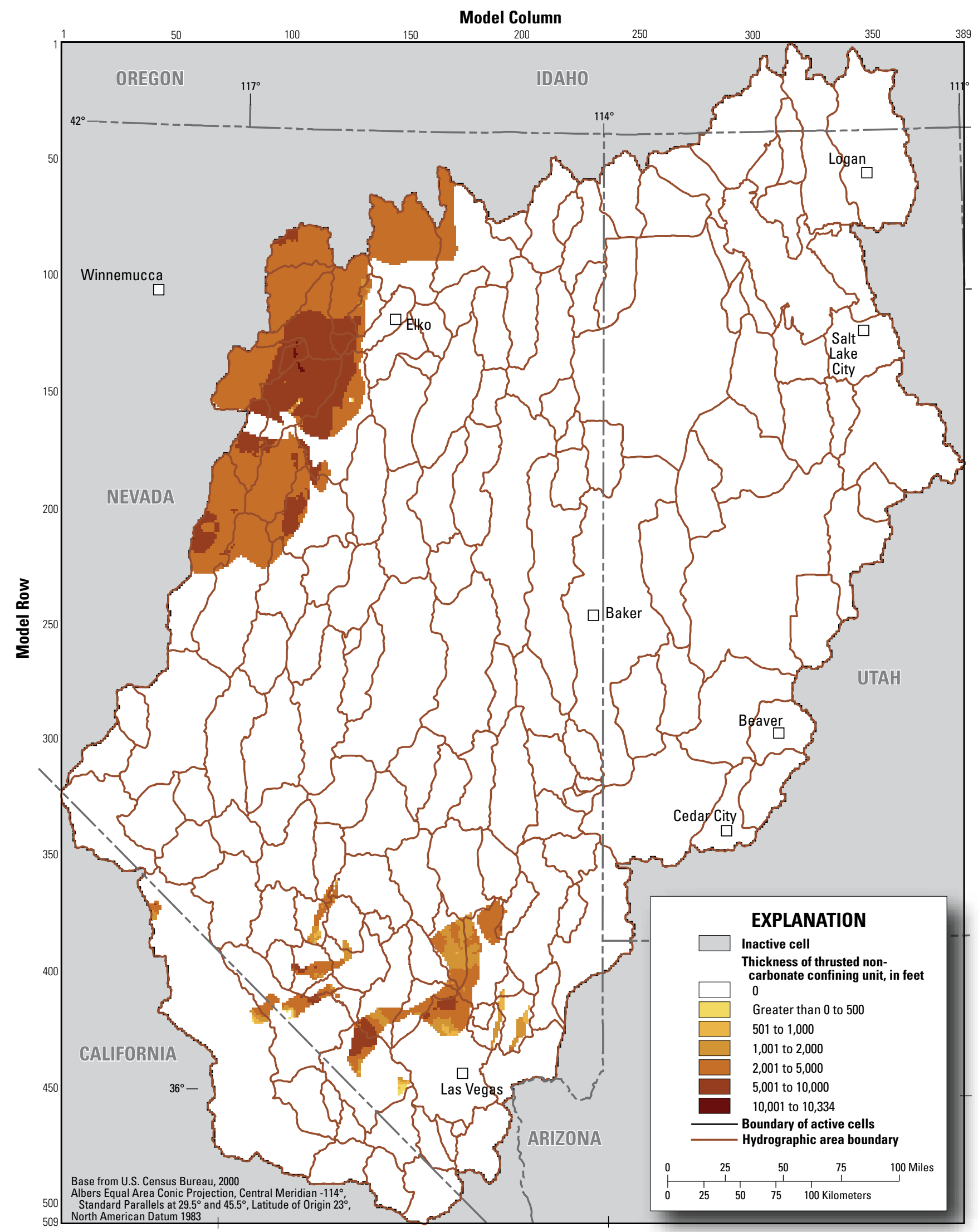

Figure 8. Thickness of the thrusted non-carbonate confining unit (TNCCU) in the numerical groundwater flow model, Great Basin carbonate and alluvial aquifer system study area. 


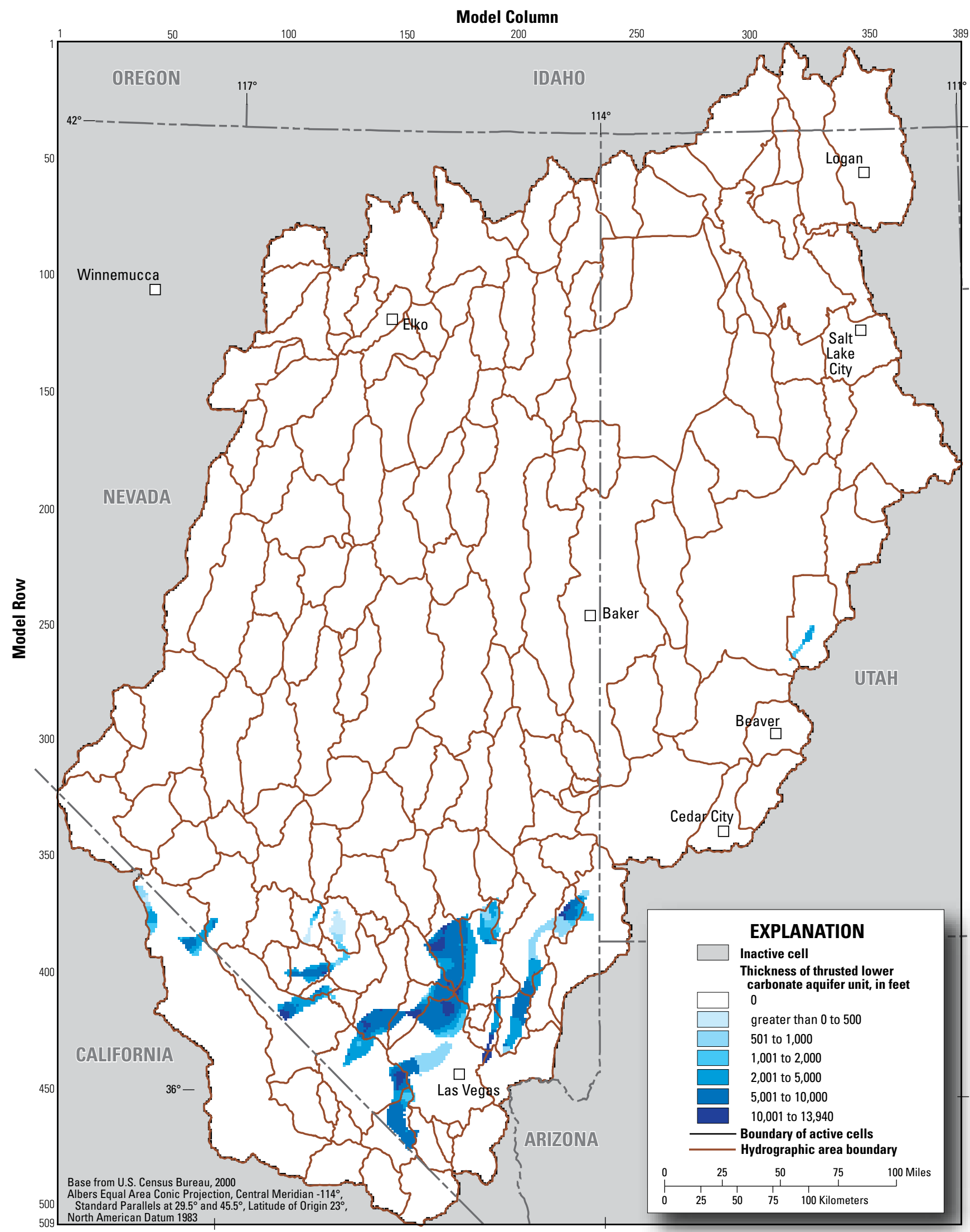

Figure 9. Thickness of the thrusted lower carbonate aquifer unit (TLCAU) in the numerical groundwater flow model, Great Basin carbonate and alluvial aquifer system study area. 


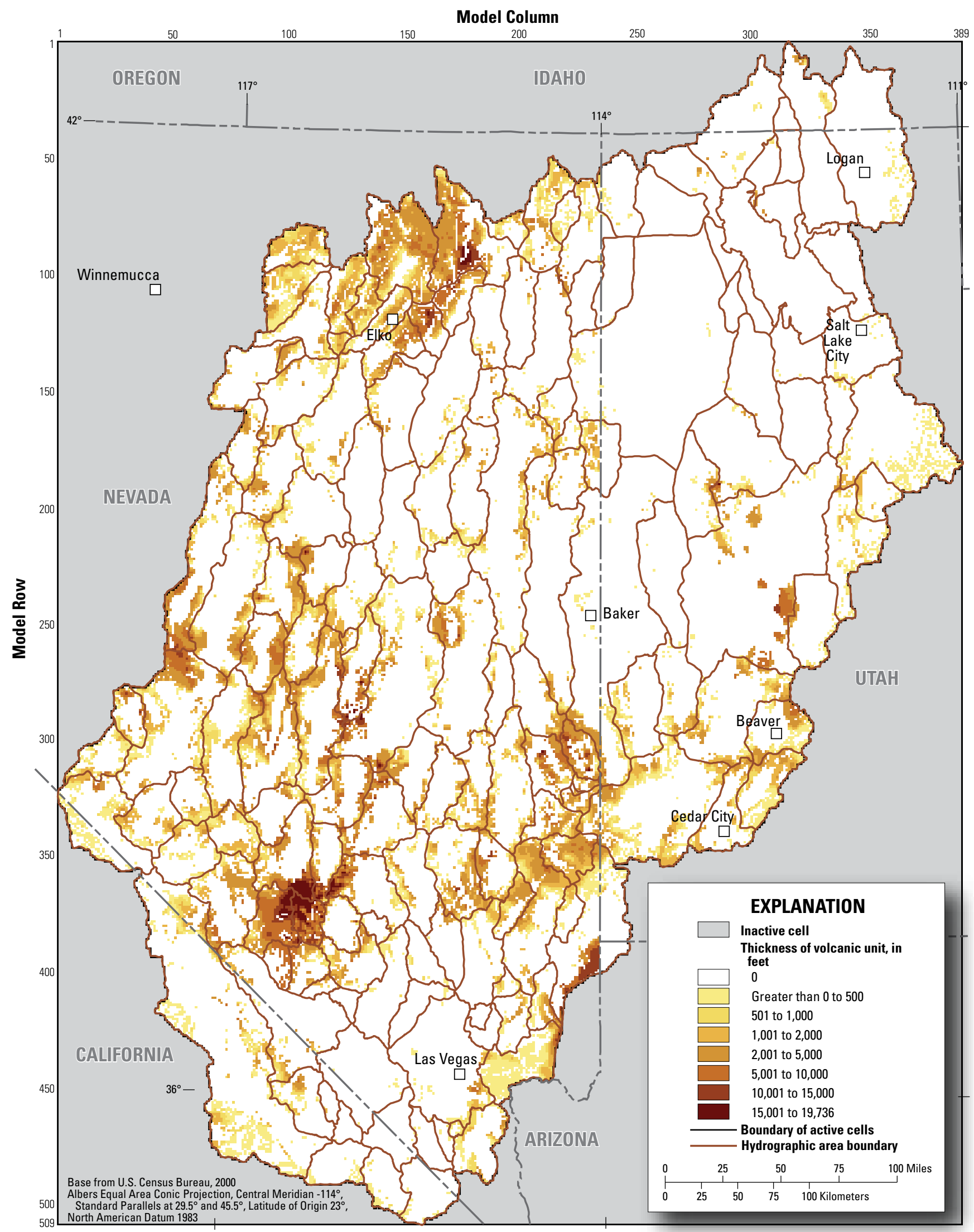

Figure 10. Thickness of the volcanic unit (VU) in the numerical groundwater flow model, Great Basin carbonate and alluvial aquifer system study area. 


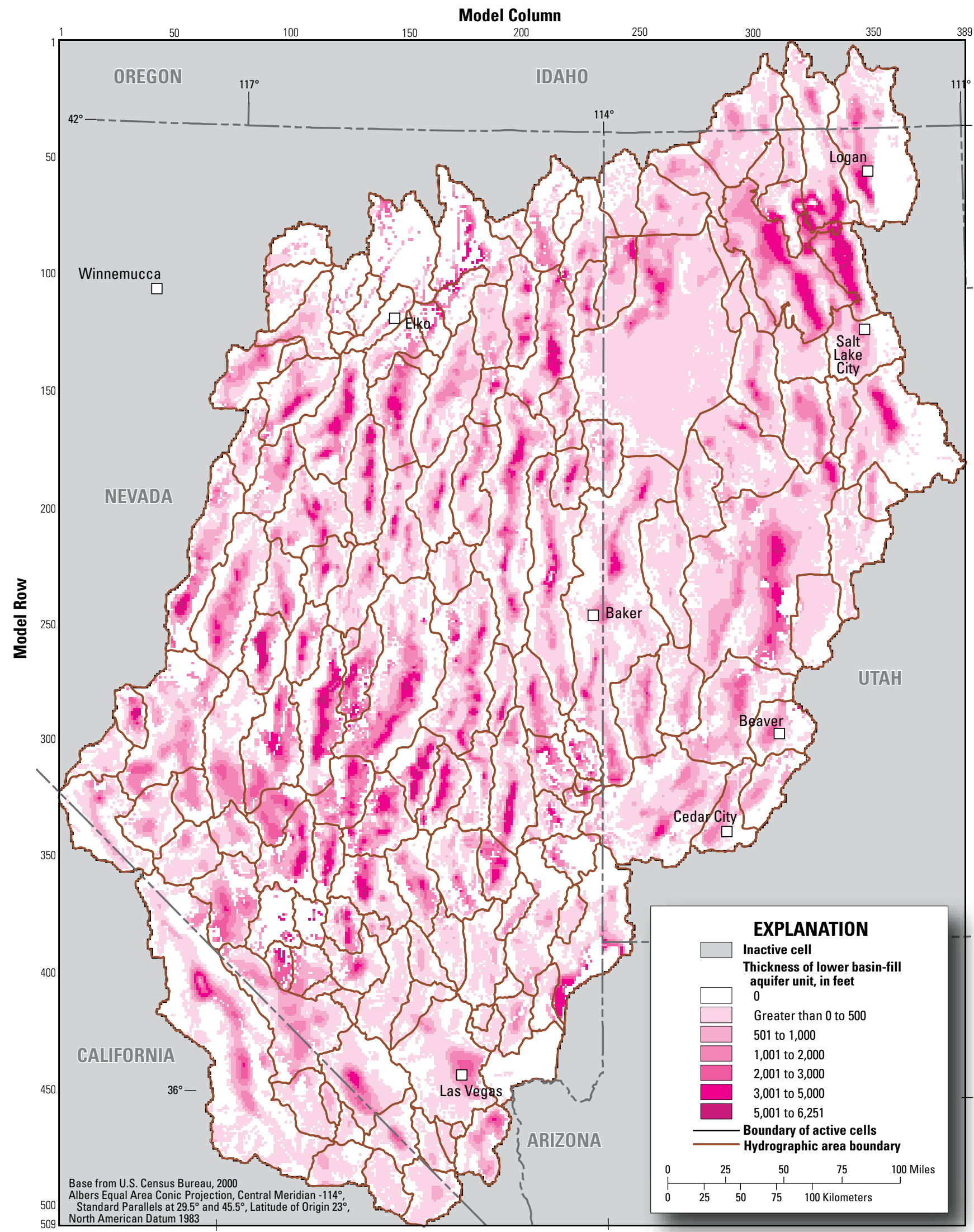

Figure 11. Thickness of the lower basin-fill aquifer unit (LBFAU) in the numerical groundwater flow model, Great Basin carbonate and alluvial aquifer system study area. 


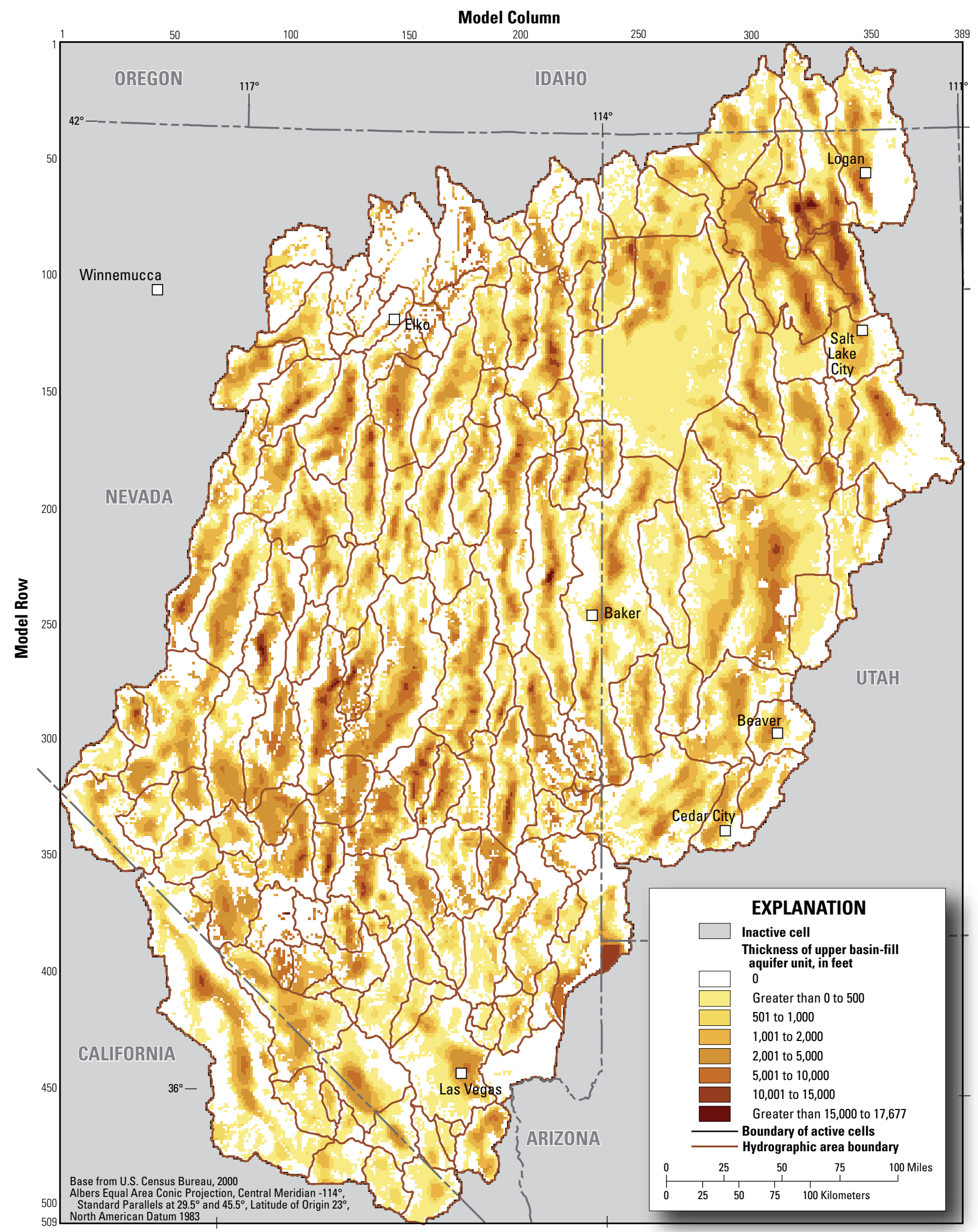

Figure 12. Thickness of the upper basin-fill aquifer unit (UBFAU) in the numerical groundwater flow model, Great Basin carbonate and alluvial aquifer system study area. 


\section{Model Construction}

The numerical model described in this report (GBCAAS model) uses MODFLOW-2005 (Harbaugh, 2005) to simulate steady-state groundwater flow, recharge, and discharge, and to calculate the simulated equivalents to water-level and discharge observations. MODFLOW-2005 is a blockcentered finite-difference code in which a three-dimensional groundwater flow system is divided into a sequence of layers organized in a roughly horizontal grid or array. MODFLOW-2005 has the following capabilities useful to a numerical model of this scale and complexity: (1) it can adequately represent the complexities of the groundwater flow system; (2) it contains methods for determining simulated equivalents to observations; (3) it includes a variety of hydrologic capabilities such as the simulation of recharge, evapotranspiration, springs, rivers, and wells; and (4) it can be applied to steady-state and transient flow conditions. MODFLOW-2005 uses model packages for parts of the simulation; all references to packages in model description refer to these packages. A geographic information system (GIS) was used to ensure accurate spatial control of physical features and the finite-difference model grid, to facilitate development of model input files, and to visualize model results.

As in any regional model, simplifications and assumptions must be made to adapt the complex conceptual model to numerical simulation. One of the major assumptions in this model is that the faults and fractures through which groundwater occurs in consolidated rocks are small and densely distributed enough to act as porous media at the scale of the model. Other assumptions include the following: hydraulic conductivity is sufficiently refined at the $1-\mathrm{mi}^{2}$ cell size; recharge is adequately distributed at the $1-\mathrm{mi}^{2}$ cell size; and small discharge boundaries, such as springs and rivers, are adequately refined at the $1-\mathrm{mi}^{2}$ cell size.

\section{Grid Definition}

The model grid (fig. 1) consists of 509 rows, 389 columns, and 8 layers, for a total of 1,584,008 cells. Model grid rows are oriented in an east-west direction, with row numbers increasing to the south; model grid columns are oriented in a north-south direction, with column numbers increasing to the east. Model grid spacing is $1 \mathrm{mi}$ in both the north-south and east-west directions. The top seven layers were initially constructed with constant thickness and constructed parallel to the top of the saturated rocks and deposits as estimated by distance-weighed interpolation of the water-level observations and altitudes of springs and mountain streams. The bottom layer has variable thickness to accommodate a constant altitude of the base of the model of $-12,000 \mathrm{ft}$. The initial thicknesses of layers 1 to 7 were 100, 150, 250, 500, 1,000, 2,000 , and 4,000 ft. Model layer 8 ranges in thickness from about 3,700 to $13,400 \mathrm{ft}$. The upper model layers are thinner to allow greater resolution where more hydrologic and geologic data are available. The number and thickness of model layers were varied during early model development to achieve the minimum number of layers that did not significantly change the simulation results.

Although the top of the groundwater system is unconfined, all model layers were designated confined because simulating layer 1 as unconfined caused numerical instability. For a steady-state model, the only implication of this is that the transmissivity of the layer does not change with change in simulated water level. Simulating layer 1 as confined is a reasonable approximation if the top of the simulated saturated thickness is close to the specified saturated thickness (Reilly and Harbaugh, 2004, p. 15). The top of the model and thickness of layers were adjusted during calibration to allow the top of the model to be close in altitude to simulated water levels and to ensure that the bottom of layer 1 is lower than simulated heads. In the final model grid, layer 1 varies in thickness from 10 to $3,500 \mathrm{ft}$, with the thickest parts of the layer being in mountainous areas that have recharge but no water-level data to define the initial top of the model (fig. 3). The top of layer 1 is never above land surface as defined by the National Elevation Dataset (NED) available from the USGS (U.S. Geological Survey EROS Data Center, 1999). The thickness of layers 2 through 6 was also adjusted, but the layers are never less than six feet thick and never more than the initial defined thickness. The model layers do not coincide with the HGUs described in Sweetkind and others (2011a). The geometry of the HGUs in this system is complex because of considerable folding, faulting, and other processes, and it is not possible for model layers to conform to these irregular shapes (fig. 3).

\section{Boundary Conditions}

The boundaries chosen for the model describe mathematically how the simulated groundwater system interacts with the surrounding hydrologic system. Mathematical boundaries used to represent hydrologic boundaries include specified-flow boundaries, head-dependent flow boundaries, and specifiedhead boundaries (Reilly, 2001, p. 1). These boundaries define both the physical limits of the model and how recharge to and discharge from the groundwater system are simulated. Specified-flow boundaries allow a specified rate of water into or out of a cell and are used to simulate the physical boundaries at the lateral edges and bottom of the model, all recharge in the model, and a very small amount of discharge in the model. No-flow boundaries are specified-flow boundaries with a flow of zero. Head-dependent flow boundaries simulate flow into or out of the model proportional to the difference in head between the model cell and the boundary (such as ETg, springs, and rivers); these boundaries are used to simulate most discharge in this model. Specified-head boundaries simulate a model cell with a head that is unchanging; selected lakes are simulated as specified-head boundaries in this model.

\section{Specified-Flow Boundaries}

Specified-flow boundaries include all cells on the model edges (lateral boundaries) and model bottom, most of which have a no-flow boundary condition. Model cells in the top 
Steady-State Numerical Groundwater Flow Model of the Great Basin Carbonate and Alluvial Aquifer System

layer of the model also have a no-flow boundary condition unless they have recharge or discharge boundaries. Specifiedflow boundaries also include specified recharge from precipitation, irrigation with surface water, and streams.

\section{Lateral and Bottom Boundaries}

The study area and model boundaries were chosen to coincide with HA boundaries. These boundaries are typically surface-water divides, are assumed to be groundwater divides along the study area boundary, and are mostly simulated as noflow boundaries (pl. 1). During natural, unstressed conditions, this assumption is considered accurate because at most of the boundaries, higher recharge rates near surface-water divides probably cause groundwater mounding and a natural groundwater divide near the ridge. A review of previous reports (Masbruch and others, 2011) found little indication of flow across the study area boundary. In some areas, however, the shape of the regional potentiometric surface and subsurface geologic conditions may result in groundwater divides that do not match the location of surface-water divides, and groundwater could move across the model boundary.

Two small parts of the study area boundary are simulated as specified-flow boundaries with non-zero flow (pl. 1). The only simulated subsurface inflow is at the south end of Lower Reese River Valley (HA 59) on the western edge of the model (pl. 1). This HA is part of the Humboldt groundwater flow system (7), and flow occurs through the HA to other parts of the Humboldt groundwater flow system within the study area. The only simulated subsurface outflow is from the eastern edges of Eldorado Valley (HA 167) and Black Mountains Area (HA 215) toward the Colorado River (pl. 1). Because very little water-level data are available at these locations, inflow and outflow were simulated as specified-flow boundaries using the Well Package (Harbaugh, 2005, p. 6-1) instead of as specified-head boundaries. Inflow of 1,192,800 ft $\mathrm{ft}^{3} / \mathrm{d}(10,000$ acre-ft/yr; Heilweil and Brooks, 2011, Auxiliary 3E) was initially simulated in HA 59 and combined outflow of 119,300 $\mathrm{ft}^{3} / \mathrm{d}$ (1,000 acre-ft/yr; Heilweil and Brooks, 2011, Auxiliary $3 \mathrm{M})$ was initially simulated in HAs 167 and 215. The amounts of inflow and outflow were defined as parameters.

Defining most lateral boundaries as no-flow boundaries is consistent with Prudic and others (1995, p. D20) in the RASA model, but differs from Faunt and others (2004, table F-18) in the DVRFS model, which simulated specified-head boundaries along the western edge of Death Valley (HA 243) that allowed about $45,000 \mathrm{~m}^{3} / \mathrm{d}(13,300$ acre-ft/yr) into the study area. The amount of recharge estimated in the current study (Masbruch and others, 2011, table D-1) indicates that additional inflow is not needed to match estimated discharge (Masbruch and others, 2011, table D-2) in the Death Valley groundwater flow system (28). In addition, the potentiometric map indicates a possible recharge mound along the western edge of Death Valley (HA 243; Heilweil and Brooks, 2011, pl. 2).

Below $-12,000 \mathrm{ft}$, the NCCU is the predominant lithology (Sweetkind and others, 2011a, fig. B-10) and probably has low permeability. The bottom of the model, therefore, is considered to be a no-flow boundary. This is similar to the altitude of the bottom of a numerical model of the DVRFS (Faunt and others, 2004, p. 266).

\section{Recharge from Precipitation, Irrigation, and Streams}

Recharge from precipitation, irrigation, and streams is simulated as a specified-flux boundary with the Recharge Package (Harbaugh, 2005, p. 8-37); applied to the highest active cell (always layer 1 in this model); and defined using multiplier arrays, zones, and parameters (Harbaugh, 2005). Four multiplier arrays define (1) recharge that occurs in-place from rainfall and snowmelt; (2) recharge that occurs from runoff in perennial, intermittent, and ephemeral streams, and from irrigation with surface water; (3) recharge that occurs from mountain-stream baseflow in streams that enter the basins, and from irrigation with mountain-stream baseflow; and (4) recharge that occurs from imported water in rivers or canals and from irrigation with imported water. Surface-water development started in the $1800 \mathrm{~s}$, but collection of enough hydrologic data on which to base a model did not start until the 1940s to 1960s. This model represents conditions with surface-water development and irrigation with surface water, but limited groundwater development. The sources of recharge were separated for consistency with Masbruch and others (2011, table D-1). Recharge parameters are used to multiply these conceptual rates and to apply the rates to specific zones (table A4-4).

Recharge from precipitation was calculated using the results of the Basin Characterization Model (BCM) average annual recharge and runoff from 1940-2006 (Masbruch and others, 2011, p. 76; Flint and others, 2011). The BCM divides available water into "in-place recharge" and "runoff." In the GBCAAS model, BCM "in-place recharge" is simulated at the same location as it occurs in the BCM (fig. 13A), but was resampled from a $270-\mathrm{m}$ grid to the 1-mi model grid using bilinear interpolation.

The BCM does not route runoff, but distributes runoff at the location it is generated (fig. 13B). In the numerical model, runoff at higher altitudes was typically redistributed to model cells along the mountain front that contained unconsolidated basin-fill material with a slope of 5 to 10 percent (fig. 13C); in this way, upland runoff was accounted for as recharge where the streams enter valleys and where irrigation with surface water occurs. This range was chosen by visual inspection of the location of streams and irrigation in selected valleys. Recharge is not simulated in areas that have been mapped as evapotranspiration areas. The distribution in some irrigated HAs includes greater portions of the flatter parts of the basins to distribute recharge more consistently to the area of applied water. Additional modifications were made in Cache Valley (HA 272), Malad-Lower Bear River Valley (HA 273), and Cedar City Valley (HA 282). In HA 272, imported water from the Bear River was only applied in the northern part of the basin, and in HA 273, it was only applied in the southern part of the basin. These are the areas where canals can supply the water by gravity flow. In HA 282, recharge from runoff and baseflow was concentrated in areas where water from Coal Creek is applied for irrigation (Brooks and Mason, 2005, p. 28). 
$\boldsymbol{A}$

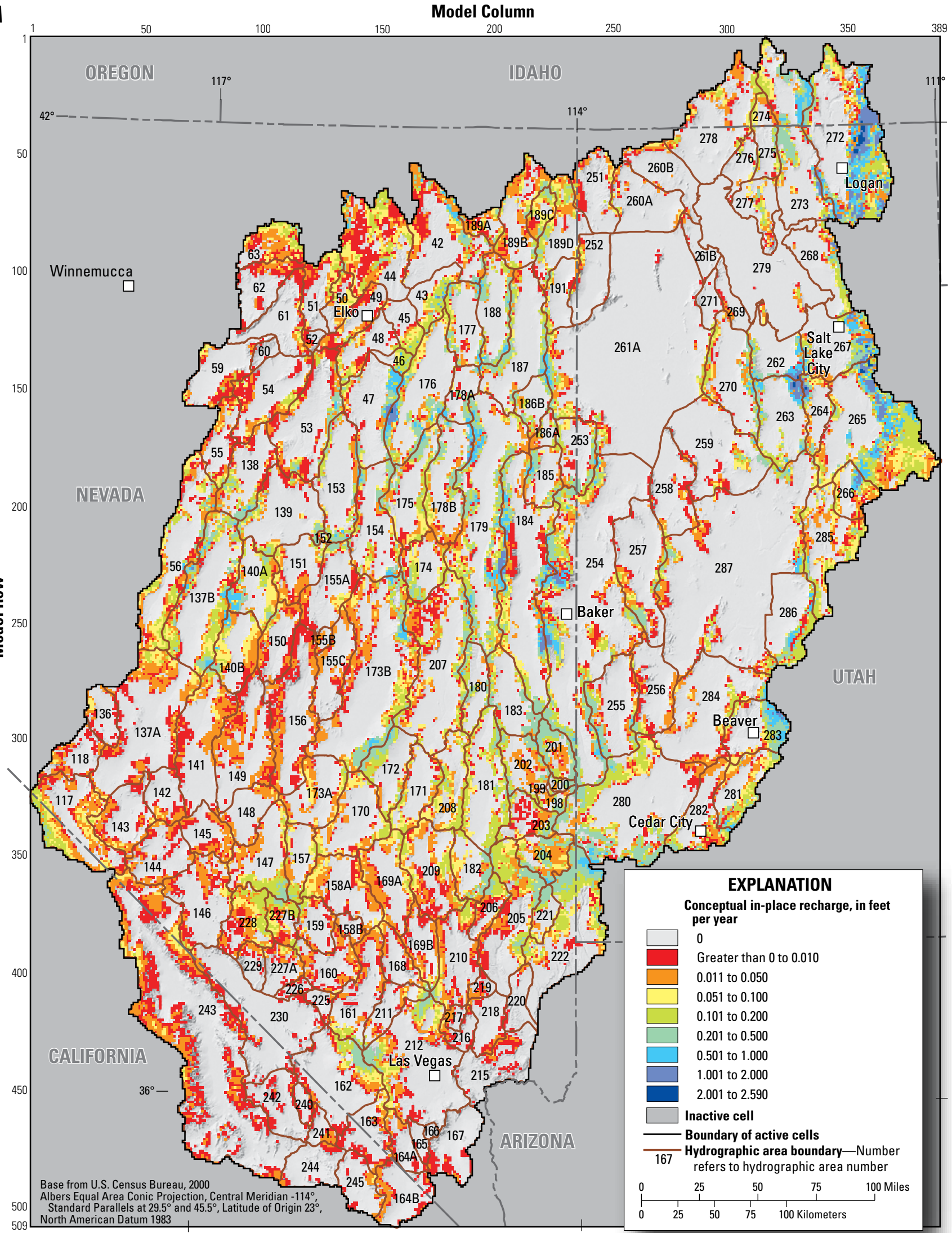

Figure 13. Rate of conceptual recharge and runoff from various sources in the Great Basin carbonate and alluvial aquifer system study area. $A$, In-place recharge; $B$, Basin Characterization Model runoff; $C$, Recharge from runoff; $D$, Recharge from baseflow; $E$, Recharge from imported water; and $F$, Total recharge. 
B

Model Column

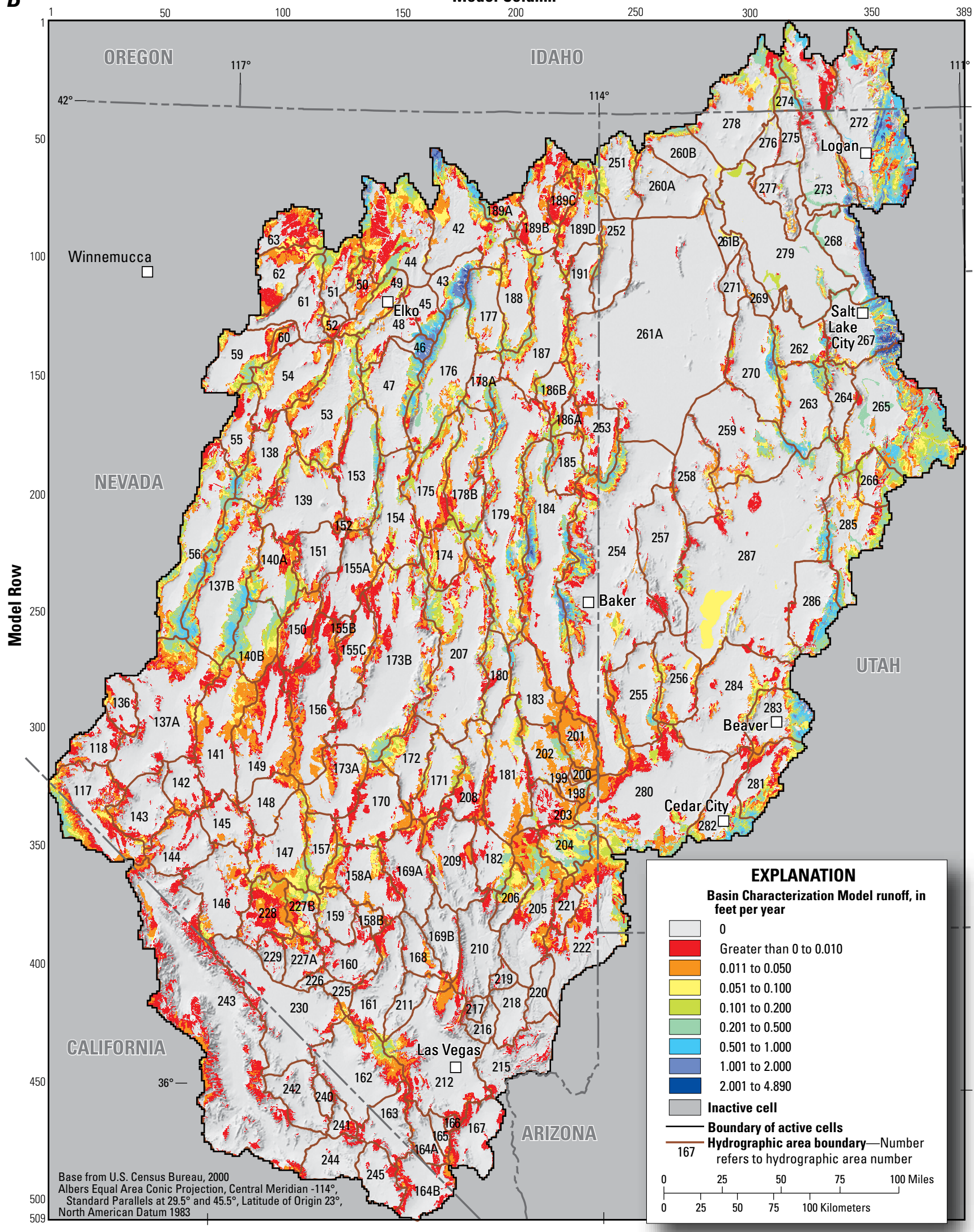

Figure 13. Rate of conceptual recharge and runoff from various sources in the Great Basin carbonate and alluvial aquifer system study area. $A$, In-place recharge; $B$, Basin Characterization Model runoff; $C$, Recharge from runoff; $D$, Recharge from baseflow; $E$, Recharge from imported water; and $F$, Total recharge.-Continued 
C

Model Column

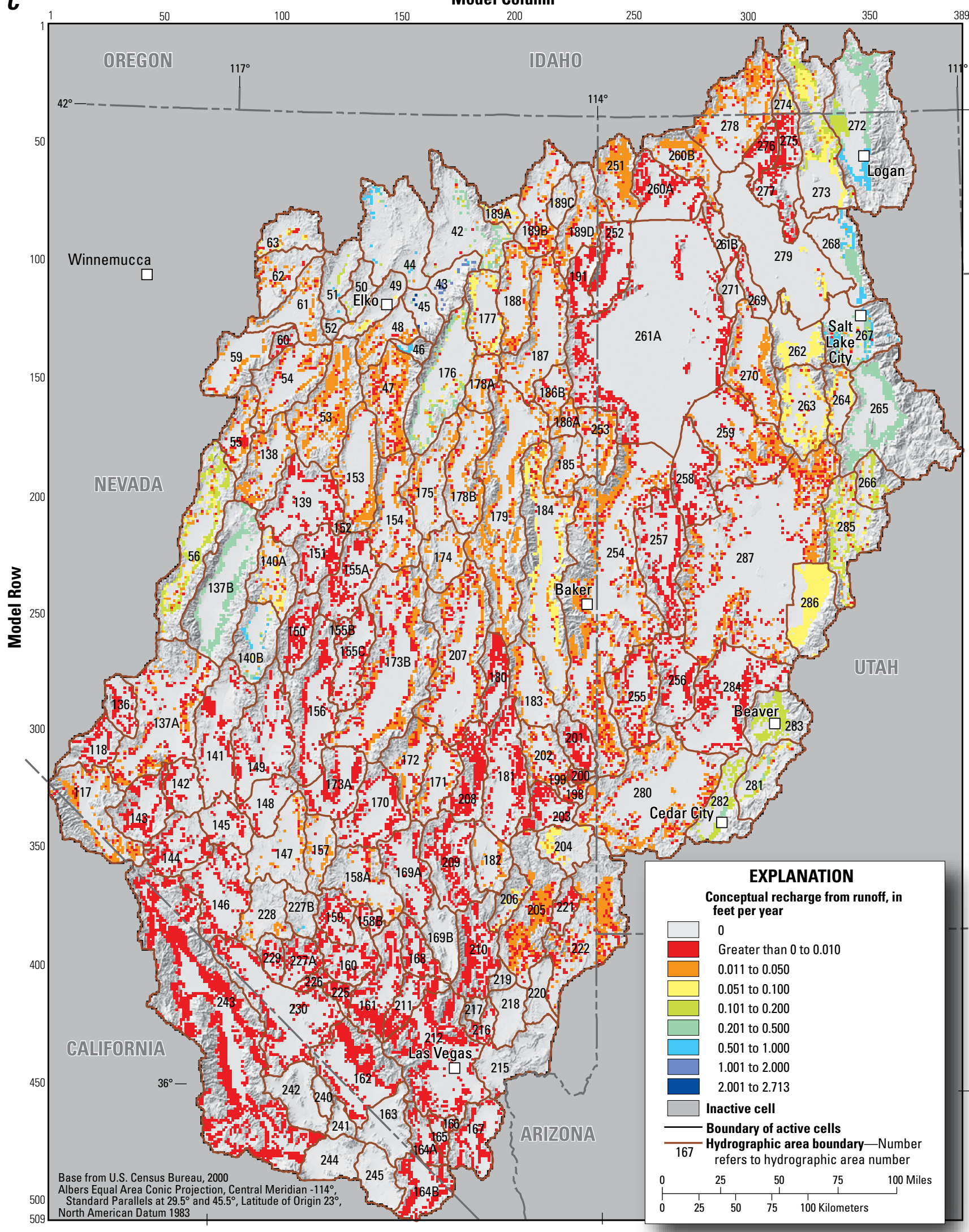

Figure 13. Rate of conceptual recharge and runoff from various sources in the Great Basin carbonate and alluvial aquifer system study area. $A$, In-place recharge; $B$, Basin Characterization Model runoff; $C$, Recharge from runoff; $D$, Recharge from baseflow; $E$, Recharge from imported water; and $F$, Total recharge.-Continued 
D Model Column

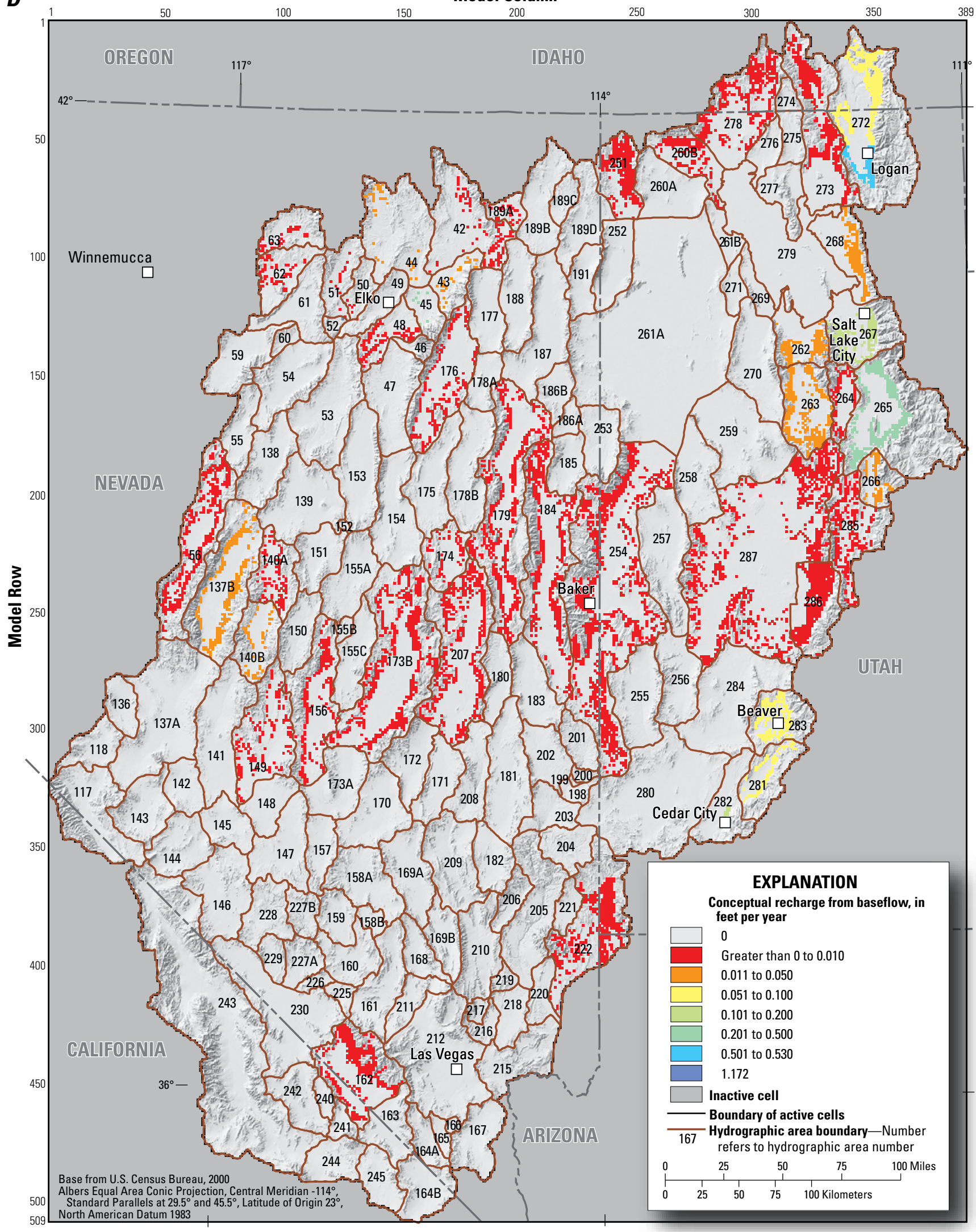

Figure 13. Rate of conceptual recharge and runoff from various sources in the Great Basin carbonate and alluvial aquifer system study area. $A$, In-place recharge; $B$, Basin Characterization Model runoff; $C$, Recharge from runoff; $D$, Recharge from baseflow; $E$, Recharge from imported water; and $F$, Total recharge.-Continued 


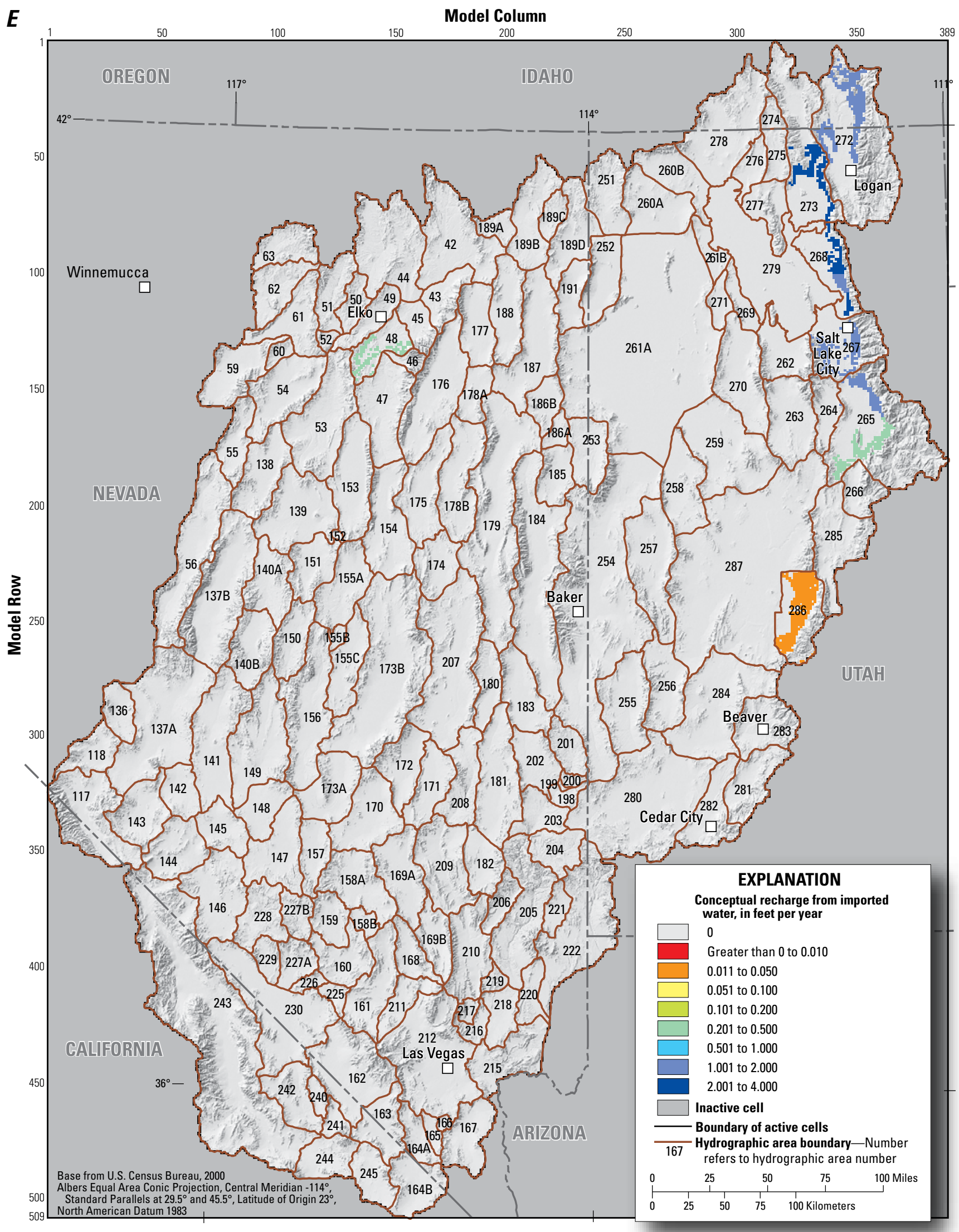

Figure 13. Rate of conceptual recharge and runoff from various sources in the Great Basin carbonate and alluvial aquifer system study area. $A$, In-place recharge; $B$, Basin Characterization Model runoff; $C$, Recharge from runoff; $D$, Recharge from baseflow; $E$, Recharge from imported water; and $F$, Total recharge.-Continued 


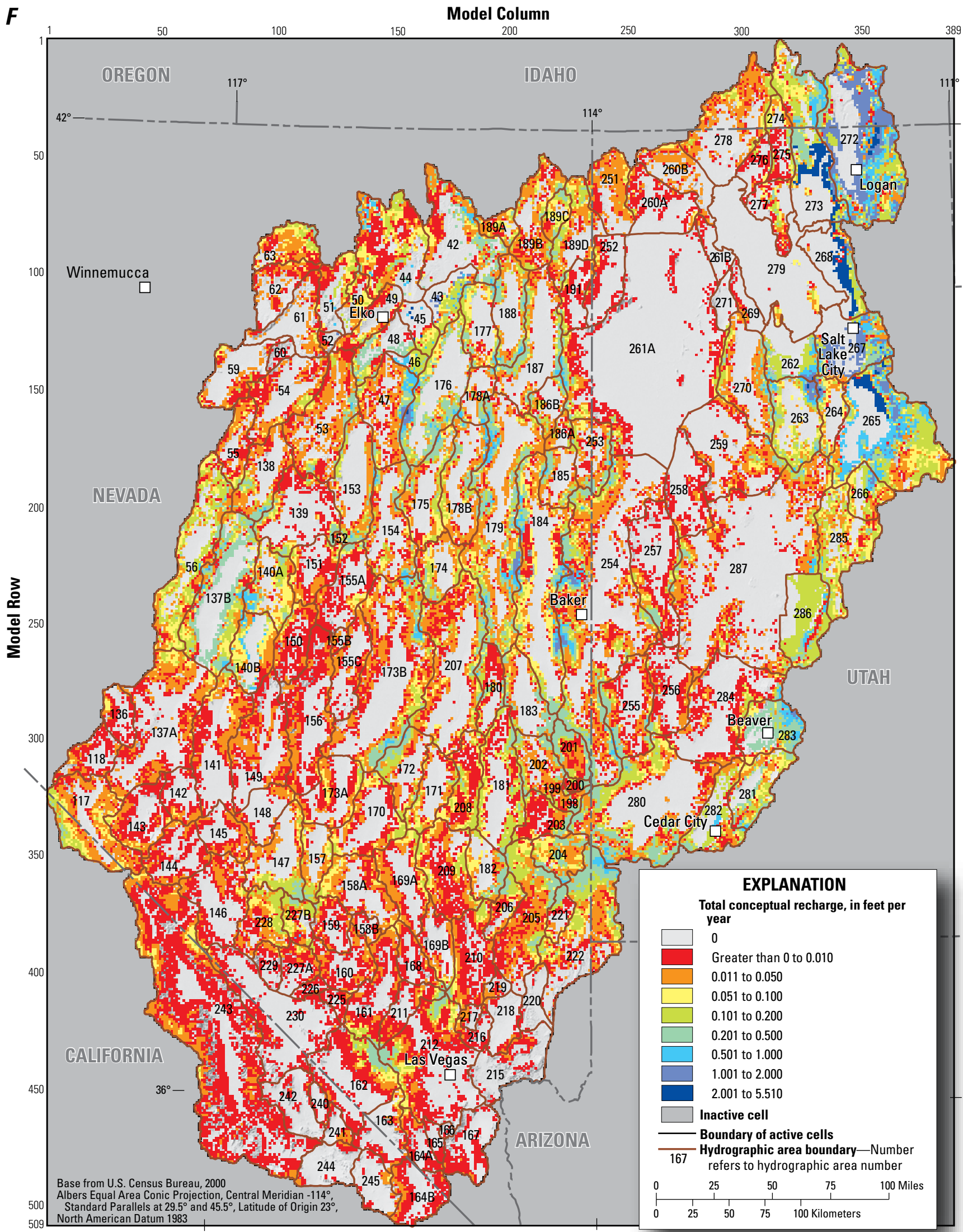

Figure 13. Rate of conceptual recharge and runoff from various sources in the Great Basin carbonate and alluvial aquifer system study area. $A$, In-place recharge; $B$, Basin Characterization Model runoff; $C$, Recharge from runoff; $D$, Recharge from baseflow; $E$, Recharge from imported water; and $F$, Total recharge.-Continued 
During this redistribution of recharge from runoff, the percent of runoff that becomes recharge was also calculated. The percent of runoff that becomes recharge is either 30 percent for HAs that are highly irrigated with surface water or 10 percent for HAs not highly irrigated with surface water (Masbruch and others, 2011, p. 86). Recharge from mountain stream baseflow (fig. 13D) and imported (fig. $13 E$ ) water was distributed to the same cells as recharge from runoff, but does not occur in every HA (Masbruch, 2011a, table A4-1).

The total conceptual recharge rates (fig. $13 F$ ) are the summation of the recharge rates from the four sources of recharge. The adjustments made in Masbruch and others (2011, p. 86-92) to balance groundwater budgets within each groundwater flow system are not made in the multiplier arrays. This allows model calibration to scale the recharge as needed without the limitation of balancing water budgets on an HA or groundwater flow system delineation.

\section{Head-Dependent Flow Boundaries}

Most discharge from the groundwater system occurs as evapotranspiration of groundwater (ETg), and discharge to springs, rivers, and lakes; these discharge processes are simulated using head-dependent flow boundaries. In cells with a head-dependent boundary, groundwater is simulated as discharging from a cell when the simulated head is above the specified boundary altitude. The rate of discharge is determined by the difference between simulated water level and boundary altitude and by the boundary conductance. Because multiple head-dependent boundaries in a single model cell can cause numerical instability, discharge from springs and rivers was combined with ETg in some areas (table A1-1). In some cells, a spring or river was simulated and ETg was not simulated. Typically, the largest or best known discharge was simulated. These groupings are appropriate at the scale of this model.

\section{Evapotranspiration of Groundwater}

ETg is simulated from layer 1 (fig. 14) using the Drain (DRN) Package (Harbaugh, 2005, p. 6-12) in areas delineated by Buto (2011). The Evapotranspiration Package (Harbaugh, 2005, p. 6-16) was not used because of numerical instability at the break in the discharge curve (Harbaugh, 2005, fig. 6-13). Similar instability was encountered in the RASA model (Prudic and others, 1995, p. D21). A numerical model of the DVRFS also used the Drain Package to simulate ETg (Faunt and others, 2004, p. 271). Required information to simulate ETg in this model is the rate of ETg, the extinction depth (drain altitude), and the depth below land surface at which the observed ETg is assumed to occur (fig. 15).

The ETg rate was calculated for each HA by summing the observed ETg, the volume of water assumed to be ETg prior to withdrawals (Masbruch and others, 2011, p. 104), and groundwater discharge to springs and rivers included in ETg in the simulation; this total was divided by the area of ETg in each HA (table A1-1) to obtain the ETg rate. ETg studies in the area have shown that the maximum rooting depth of certain phreatophytes can be as deep as 35 to $60 \mathrm{ft}$ (Moreo and others, 2007). To simulate a rooting depth of $40 \mathrm{ft}$ in this model, the drain altitude is specified as $40 \mathrm{ft}$ below land surface as determined from the NED at the center of the ETg area in each cell. The drain altitudes of ETg cells near Great Salt Lake are set at the altitude of the lake $(4,200 \mathrm{ft})$ because it is likely that little evapotranspiration occurs below this depth. As salt content of soil increases, it becomes more difficult for plants to take up water (Ogle and St. John, 2010, p. 3). It is assumed that the observed ETg occurs when the average water level is about $5 \mathrm{ft}$ below land surface. Drain conductance was initially defined as the conceptual rate of evapotranspiration (table A1-1) divided by $35 \mathrm{ft}$ multiplied by the area of ETg in each cell (fig. 15). Only the portion of a cell in the ETg area is included in the calculation. Cells with less than 4 percent of the cell area in ETg areas were not included as ETg drain cells in the model. Drain parameters in this model are multipliers of the initial drain conductance.

This method of simulating ETg allows ETg to vary linearly from the conceptual rate to zero when the simulated hydraulic head is from 5 to $40 \mathrm{ft}$ below land surface, which is similar to the method used by the Evapotranspiration Package (Harbaugh, 2005, fig. 6-13). The Drain Package does not limit the maximum rate of discharge (Harbaugh, 2005, fig. 6-10), so defining ETg as drains in this model allows ETg to be higher than the conceptual rate when simulated heads are within $5 \mathrm{ft}$ of land surface or above land surface.

\section{Springs}

Discharge to springs (fig. 16; table A1-2) is simulated from multiple layers using the Drain Package (Harbaugh, 2005, p. 6-12). Drain altitudes for springs are set at the altitude reported in the USGS National Water Information System (NWIS; Mathey, 1998) or determined from the NED (U.S. Geological Survey EROS Data Center, 1999), but a minimum of $10 \mathrm{ft}$ below the altitude of land surface at the center of the grid cell as determined from the NED. The altitudes of a few springs near Great Salt Lake and Utah Lake are not a minimum of $10 \mathrm{ft}$ below the NED because those altitudes would put them below the constant-head boundary of 4,200 ft or 4,489 ft, respectively, simulated at the lakes.

Most spring discharge areas represent individual springs that are substantially smaller in area than the simulated $1-\mathrm{mi}^{2}$ grid cell. At this scale, it is not possible to represent local variations in hydraulic gradient, fault and fracture geometry, and abrupt changes in lithology that influence groundwater discharge rates. Because of these simplifications in representing spring discharge areas in the model, errors in simulation can result.

Springs with flow rates less than $300 \mathrm{gal} / \mathrm{min}$ were not simulated unless they were near other springs. These smaller springs could represent local conditions that are not simulated in this regional model, such as perched conditions or irrigation return flow. Discharge from springs that are less than $300 \mathrm{gal} / \mathrm{min}$ accounts for less than 2 percent of the discharge 


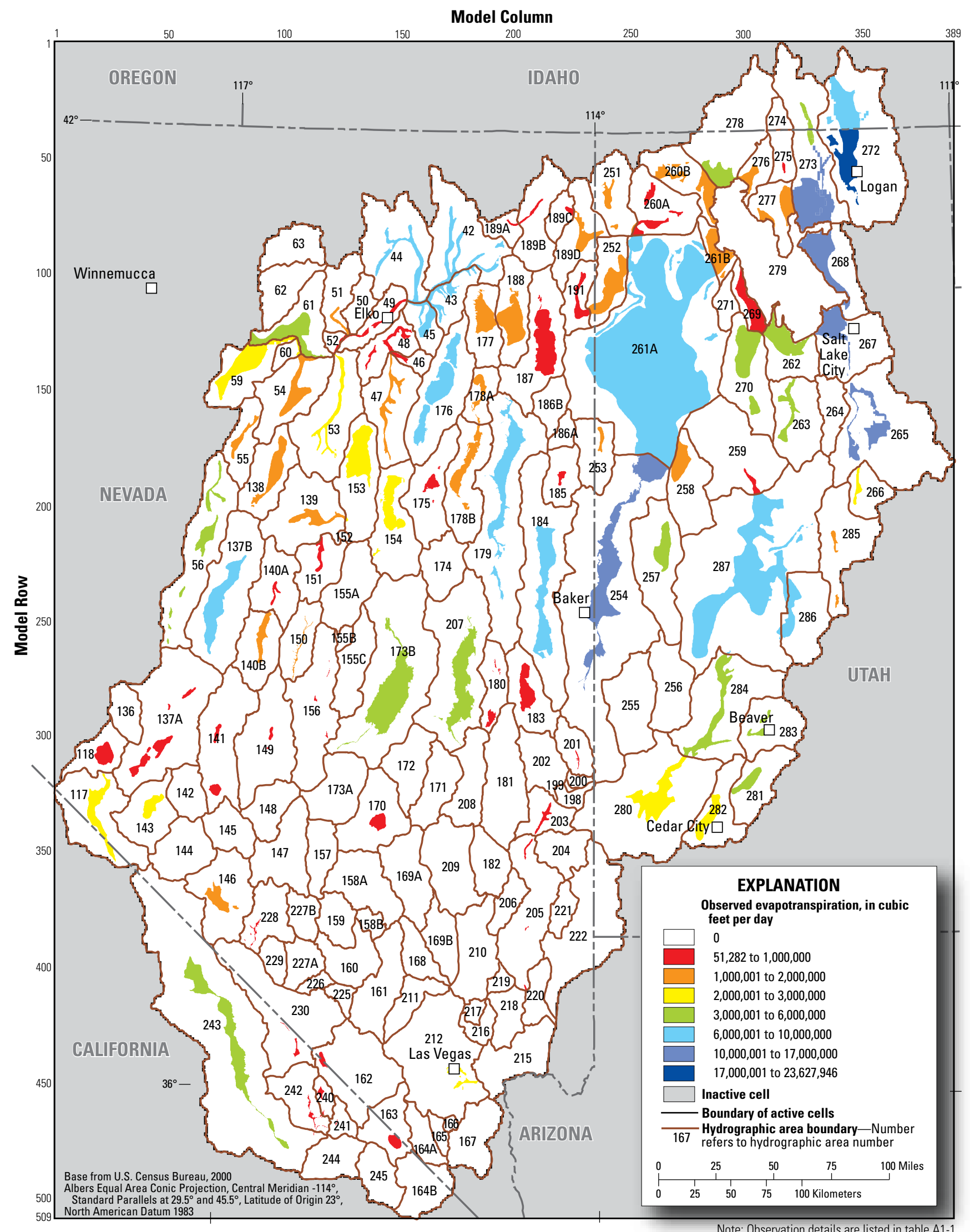

Figure 14. Distribution of observed evapotranspiration of groundwater in the numerical flow model, Great Basin carbonate and alluvial aquifer system study area. 


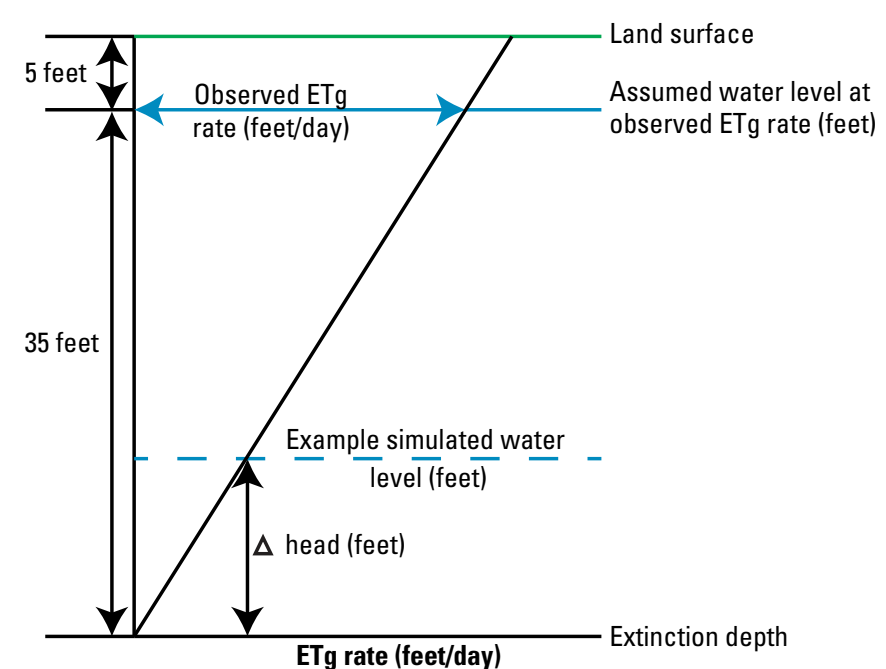

ETg is evapotranspiration of groundwater

Conductance $(C D)=0$ bserved ETg rate $\div 35$ feet

Cell conductance factor $(C F)=C D \times$ area $\left(\right.$ feet $\left.^{2}\right)$ of ETg area in cell

Parameter is a dimensionless multiplier of the CF

Simulated ETg $\left(\right.$ feet $^{3} /$ day $)=$ Parameter $\times C F \times \Delta$ head

Figure 15. Calculation of drain conductance used to simulate evapotranspiration of groundwater in the numerical flow model, Great Basin carbonate and alluvial aquifer system study area.

for the study area (Masbruch and others, 2011, p. 103). Springs discharging less than $300 \mathrm{gal} / \mathrm{min}$ and springs that were combined with other discharge boundaries and not simulated as individual springs are listed in table A1-3.

The conductance of drains representing springs are defined as parameters in the groundwater flow model. Drain conductance is defined by the conductance factor multiplied by the parameter value. The conductance factor for all point springs is one-tenth of the cell area. Large seeps without definite point locations are defined as area springs (fig. 16); the conductance factor for area springs is the area of the spring in each cell.

All springs are simulated in layer 1 and deeper layers were added as needed to achieve closer match to observed spring discharge. Large springs typically involve multiple model layers. This simulates the mixture of discharge to springs that occurs (Toth, 1963), prevents vertical gradients from developing in cells representing deep springs, and more closely represents the probable vertical flow path and possible dissolution of lithologic material that has occurred at the spring and that enhances spring discharge. This representation of springs differs from the DVRFS numerical model which considered all large springs to be connected only to the LCAU (Faunt and others, 2004, p. 278) and the RASA numerical model which considered all large springs to be only in model layer 2 of a 2-layer model (Prudic and others, 1995, p. D22). It is possible that simulating large springs only from deeper layers would force the model to move more water to deeper layers than may actually occur and neglect the existence of local systems. Toth (1963, p. 4808) states that neglecting the existence of local systems is not justified.
The GBCAAS model includes spring discharge in mountain ranges. Previous regional studies in the area have assumed that the regional water table is below the altitude of mountain springs and that the discharge from those springs represents perched discharge from locally derived recharge (Bedinger and Harrill, 2004, p. 358; Wilson, 2007, p. 5). Prudic and others (1995, p. D21-D22) simulate small springs in the valleys as part of evapotranspiration areas and simulate large springs only if they have altitudes similar to valley floors; springs in the mountain ranges are not simulated. Higher-altitude springs were included in the GBCAAS model for the following reasons:

1. Because the BCM is used to estimate recharge, ignoring the discharge of higher-altitude springs would require a reduction in recharge equal to the discharge from those springs. If not, some recharge that occurs near these springs would inaccurately remain in the model and discharge at a location farther downgradient.

2. Even though downward vertical gradients probably exist in mountain recharge areas, it is unlikely that all mountain springs are entirely separate from the regional groundwater system. The omission of small springs in this model allows that some springs are probably perched.

3. Ignoring discharge to springs in mountains also assumes that water levels in mountains are about the same as water levels in nearby valleys. This does not account for recharge mounds that probably occur beneath highrecharge areas in the mountains.

\section{Rivers}

Streams and rivers (fig. 17) are simulated as head-dependent boundaries in model layer 1 with the River (RIV) Package (Harbaugh, 2005, p. 6-6). In one location in HA 263, a river is simulated in deeper cells to simulate the spring at the beginning of the river. Perennial streams in mountainous areas are simulated to allow recharge in these areas to discharge as baseflow. Similar to mountain spring discharge, ignoring the discharge to streams in the mountains would assume that water levels in mountains are about the same as water levels in nearby valleys and would not account for recharge mounds that probably occur beneath high-recharge areas in the mountains. Simulating streams in the mountains also provides sensitivity to model parameters in those areas. Most mountain streams with a gaging station located within about $1,300 \mathrm{ft}$ of consolidated rock and a minimum mean daily discharge greater than 0 (perennial during at least 1 year of record) were simulated in the GBCAAS model. Rivers are also simulated in selected basins to allow discharge from unconsolidated deposits to a few large rivers (fig. 17; tables A1-4 and A1-5). Some streams and rivers were not simulated because of their small amount of flow or because they were combined with another head-dependent boundary condition (tables A1-6 and A1-7).

The locations of simulated rivers were determined from the Medium Resolution National Hydrography Dataset (U.S. Geological Survey, variously dated). River altitude (stage) was 


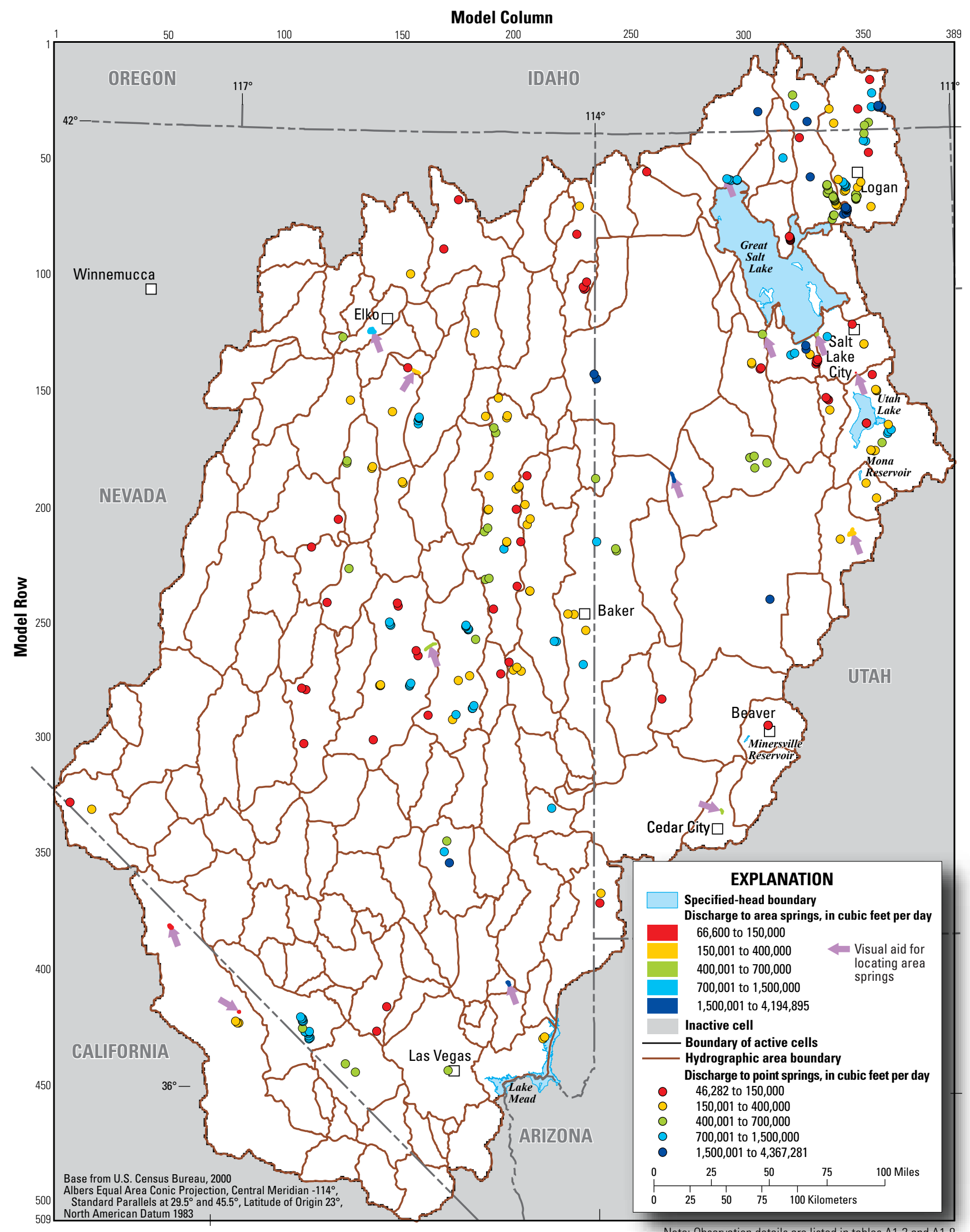

Figure 16. Location of and observed discharge to simulated springs and location of specified-head boundaries in the numerical groundwater flow model, Great Basin carbonate and alluvial aquifer system study area. 


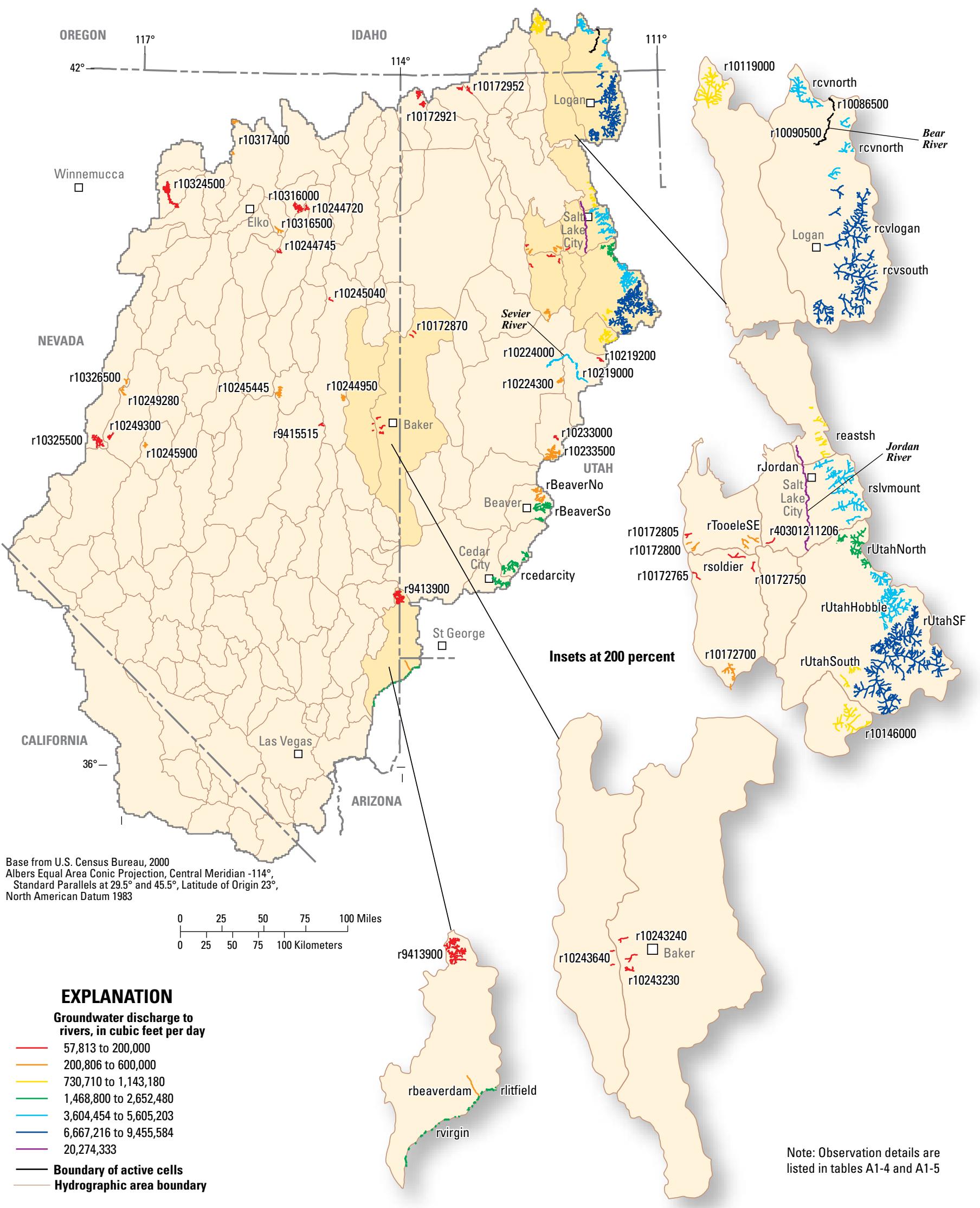

Figure 17. Location of and observed discharge to simulated rivers in the numerical groundwater flow model, Great Basin carbonate and alluvial aquifer system study area. 
determined at multiple points along each river reach from the NED (U.S. Geological Survey EROS Data Center, 1999), and the minimum altitude of the river in each model cell was used as the river stage in the cell. The small difference between land altitude and river altitude is insignificant at the scale of this model. Mountain streams probably do not gain along their entire length, but records are not detailed enough to determine gaining versus losing reaches. As an estimate of gaining locations, only river segments with altitudes below or equal to the average altitude above the gage were simulated. This appears reasonable in comparison to land-surface altitudes in that most of the simulated reaches occur in more deeply incised canyons.

The River Package defines recharge and discharge through river cells as the product of riverbed conductance times the head difference between the river altitude and the simulated head in each cell (Harbaugh, 2005, eq. 6-5). Riverbed conductance is a function of the hydraulic conductivity of the riverbed material, the length of the river in each cell, the width of the river, and the thickness of the riverbed. In this model, the length of the river in each cell is specified, and parameters define the hydraulic conductivity of the riverbed multiplied by the width of the river divided by the thickness of the riverbed. Because only rivers are simulated that have measurements indicating that groundwater discharges to the river, the altitude of the bottom of the riverbed is set equal to river stage at all locations to prevent simulated recharge from rivers (Harbaugh, 2005, eq. 6-8). Recharge from streams and rivers is included in the Recharge Package and distributed over the HA as described in the "Recharge from precipitation, irrigation, and streams" section of this report.

\section{Specified-Head Boundaries}

Discharge to large lakes is simulated using specified-head boundaries in layer 1 with the Time-Variant Specified Head Option (CHD; Harbaugh, 2005, p. 4-2). Only the largest lakes or lakes with estimates of groundwater inflow are simulated (fig. 16; table A1-8). Discharge or recharge from small lakes is considered negligible at this regional scale.

\section{Hydraulic Properties}

The nine HGUs described in Sweetkind and others (2011a) are the basis for assigning horizontal hydraulic conductivity and vertical anisotropy to the model layers. The HGUs are simulated by using the Hydrogeologic-Unit Flow (HUF) Package (Anderman and Hill, 2000; 2003), which can represent the complexities of the geology (fig. 3). Hydrogeologic structures that act as barriers to groundwater flow are simulated by using the Horizontal-Flow Barrier (HFB) Package (Harbaugh, 2005, p. 8-32 to $8-33$ ).

\section{Hydrogeologic Units}

The HUF Package takes as input the top and thickness of each HGU, and allows the hydraulic conductivity and vertical anisotropy of the HGUs to be defined through zones and parameters. The tops of the HGUs (Cederberg and others, 2011) are used as the tops of the HUF units in the model; thickness of an HUF unit is defined as the top of the HGU minus the top of the next lower HGU. Horizontal hydraulic conductivity and vertical anisotropy (the ratio of horizontal to vertical hydraulic conductivity) is defined for each HGU by using the HUF Package, parameters, and zones. The HUF Package determines the HGUs that apply to each model cell (Anderman and Hill, 2000, fig. 1C). Some model cells are filled by a single HGU, while other model cells contain multiple HGUs. The HUF Package calculates the effective hydraulic conductivity in both the vertical and horizontal directions for each cell (Anderman and Hill, 2000, p. 7).

\section{Structures Simulated as Barriers}

Much of the geologic complexity in the GBCAAS is caused by faults. Faults can create barriers to groundwater flow by juxtaposition of low-permeability materials and relatively high-permeability materials, and by low-permeability material (fault gouge) in the fault zone itself, which forms a barrier to flow across the fault (Caine and others, 1996). Juxtaposition is represented in the flow model by the geometry of the hydrogeologic framework (Cederberg and others, 2011). Faults, or portions of faults, that appear to create an additional barrier to flow are simulated by using the HFB Package (Hsieh and Freckleton, 1993). These flow barriers (fig. 18) are located along cell boundaries to approximate the location of selected major faults (Sweetkind and others, 2011a, fig. B-8). HFBs are simulated in all model layers except in a few areas where they were removed from the upper layers to prevent simulated water levels from being above land surface on the upgradient side of the barrier. The model input required for the HFB Package is the hydraulic characteristic of the barrier, which is the hydraulic conductivity of the barrier divided by the width of the barrier. It is assumed in this model that the width is $1 \mathrm{ft}$. The hydraulic conductivity is defined using parameters. 


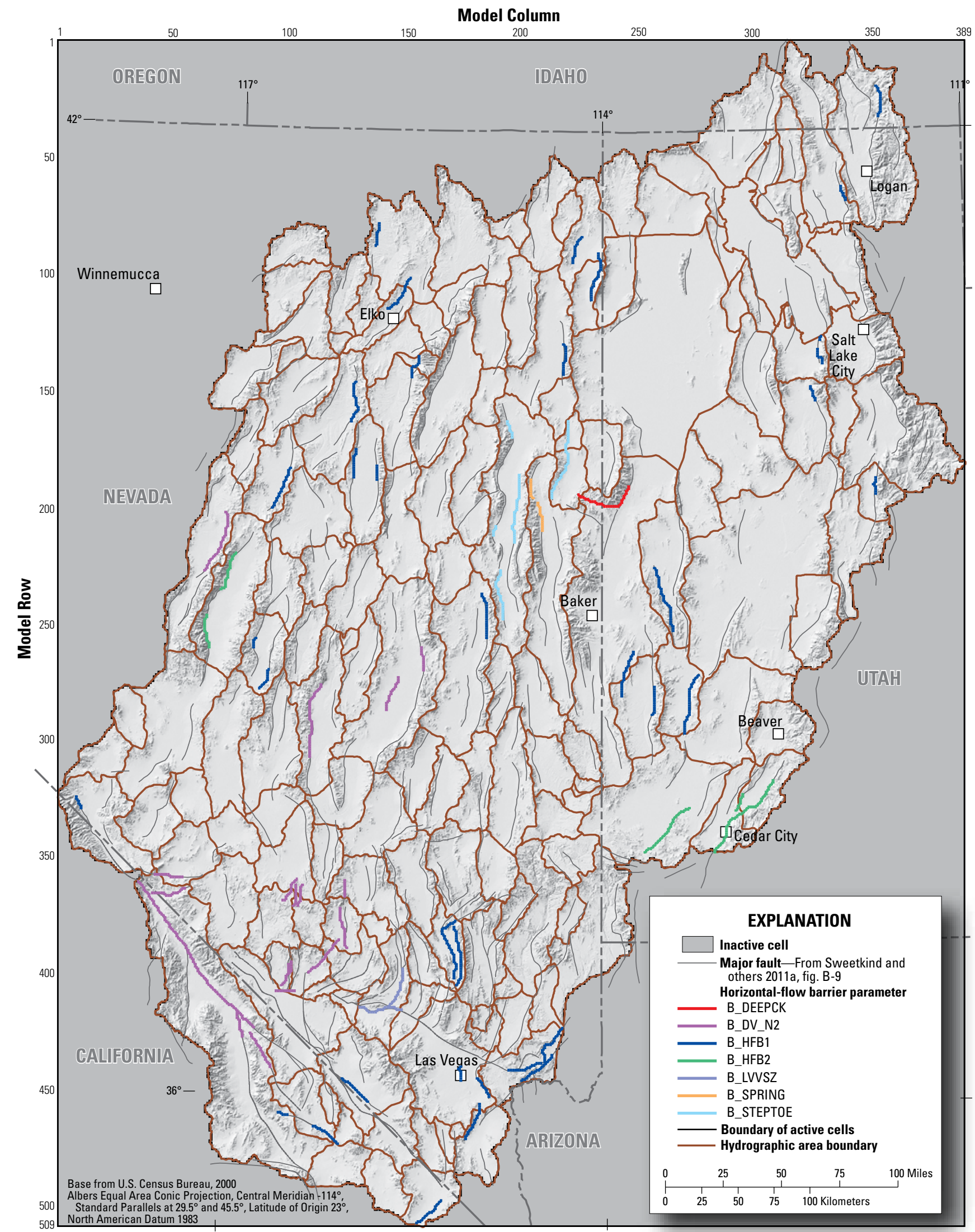

Figure 18. Major faults and horizontal-flow barriers representing selected faults in the numerical groundwater flow model, Great Basin carbonate and alluvial aquifer system study area. 


\section{Observations Used in Model Calibration}

The term "observation" is used to denote that model output will be compared to a measured value of water level or discharge, and that the comparison is part of calibration, sensitivity analysis, and parameter estimation. Model observations used to calibrate the GBCAAS model are water levels at wells and discharge locations, and discharge to ETg, springs, rivers, and lakes (table 4). For each observation, uncertainty was determined as part of model input. Uncertainties were expressed as standard deviation, variance, or coefficient of variation, and were converted to variances that UCODE_2005 (Poeter and others, 2008) uses to define weights (1 divided by the variance). Weights are applied to the observations for calibration statistics, sensitivity analysis, and parameter estimation.

All observations used in the model are considered representative of steady-state conditions. Some wells and springs have multiple measurements over several years. If a trend indicated that groundwater withdrawals were affecting water levels or discharge, the data from affected years were not used. Natural discharge from ETg was considered to be constant and not influenced by groundwater withdrawals in most areas, but was influenced by groundwater withdrawals in selected HAs. In those areas, the adjusted values of ETg (Masbruch, 2011b, table A5-1) were used as the observation to represent conditions before groundwater withdrawals began.

\section{Water Levels in Wells and Uncertainty}

Water levels measured in wells located within the model domain were used to develop water-level observations for calibration of the flow model (table A2-1). A previous analysis (Claudia Faunt, U.S. Geological Survey, written commun., September 21, 2007) was used to determine which water levels in the DVRFS were representative of regional groundwater conditions. A detailed analysis of water levels in other parts of the GBCAAS was beyond the scope of this project, but some water levels were deleted as possibly erroneous or not representative of the regional water table. Specific reasons why selected water levels were not used are listed in table A2-2. Also, because of the regional scale of this model and the disproportionate amount of water-level data available in the most developed areas, not all wells with water-level measurements are represented in the observations. Many basins have hundreds of wells in close proximity to each other, usually completed in the shallow basin fill, and data clustering could negatively impact the model calibration. In these areas, observation wells were selected on the basis of the following factors: (1) wells with multiple water-level measurements, (2) wells with water levels measured before major groundwater development, (3) wells that were completed in different HGUs or different model layers, (4) wells with supporting data (such as depth and perforated interval), and (5) wells that were located to represent general water-level gradient trends in basins. Some water levels are used that were measured during more recent groundwater development, but only in areas thought to be minimally impacted by groundwater development and where earlier measurements were not available.

Table 4. Summary statistics of observations in the numerical groundwater flow model, Great Basin carbonate and alluvial aquifer system study area.

[All water-level observations in feet. All discharge observations in cubic feet per day. Average standard deviation in feet squared. Weights of discharge observations were increased for calibration, and average weighted coefficient of variation is value used in model regression and fit statistics. Abbreviations: -, not applicable]

\begin{tabular}{|c|c|c|c|c|c|c|c|}
\hline Type of observation & $\begin{array}{c}\text { Number of } \\
\text { observations }\end{array}$ & $\begin{array}{c}\text { Minimum } \\
\text { observation }\end{array}$ & $\begin{array}{c}\text { Maximum } \\
\text { observation }\end{array}$ & $\begin{array}{c}\text { Average } \\
\text { observation }\end{array}$ & $\begin{array}{l}\text { Average } \\
\text { standard } \\
\text { deviation }\end{array}$ & $\begin{array}{c}\text { Average } \\
\text { coefficient of } \\
\text { variation }\end{array}$ & $\begin{array}{c}\text { Average } \\
\text { weighted } \\
\text { coefficient of } \\
\text { variation }\end{array}$ \\
\hline \multicolumn{8}{|c|}{ Water levels } \\
\hline Water-level altitude in wells & 1,529 & -280 & 9,645 & 4,567 & 23.6 & - & - \\
\hline River altitudes & 33 & 4,897 & 8,632 & 6,731 & 31.6 & - & - \\
\hline Spring altitudes & 187 & 680 & 8,235 & 5,182 & 28.9 & - & - \\
\hline Total & 1,749 & -280 & 9,645 & 4,674 & 24.3 & - & - \\
\hline \multicolumn{8}{|c|}{ Discharge $^{1}$} \\
\hline Spring discharge & 158 & $-46,282$ & $-4,367,281$ & $-545,725$ & - & 0.27 & 0.12 \\
\hline Evapotranspiration & 102 & $-51,282$ & $-23,627,946$ & $-3,120,378$ & - & 0.30 & 0.13 \\
\hline River discharge $^{2}$ & 53 & $-57,813$ & $-20,274,333$ & $-1,550,229$ & - & 0.24 & 0.11 \\
\hline Lake discharge & 5 & $-143,000$ & $-6,798,000$ & $-2,652,340$ & - & 0.30 & 0.13 \\
\hline Total & 318 & $-46,282$ & $-23,627,946$ & $-1,572,242$ & - & 0.28 & 0.12 \\
\hline
\end{tabular}

${ }^{1}$ Discharge is considered negative in MODFLOW. A larger discharge, therefore, is a more negative number.

${ }^{2}$ Fifty-six river observations are used in MODFLOW for budget accounting, but the amount of groundwater discharge to three of the rivers is not known, and they are not used as UCODE observations for calibration. 
Water levels at 1,529 wells (fig. 19; table A2-1) were defined as steady-state water-level observations. The calibration target at each well is the average water level over the time period for which water-level measurements in the well were used. Decadal and seasonal fluctuations were treated as noise in the observations and are accounted for through an analysis of observation errors. Wells were used as observations only if their land-surface altitude and depth were known. The open intervals of wells were used to determine the model layers associated with the observations. For wells open to more than one model layer, simulated heads are a weighted average calculated by the MODFLOW-2005 Head Observation Package (HOB) on the basis of the length of open interval in each layer (Harbaugh and Hill, 2009, p. 5). Most of the wells have open intervals and completion depths in the upper model layers (table 5).

Some errors that contribute to the uncertainty of water-level observations are inaccuracies in the altitude and location of a well; inaccuracies in the measurement of water levels; and fluctuations caused by variations in climate, anthropogenic stresses, or any other nonsimulated transient stress. These errors were estimated from available information and were used to quantify the uncertainty of each water-level observation using methods from San Juan and others (2004) as explained in Appendix 2. In addition, errors caused by model discretization and depth of well (Appendix 2) result from inaccuracies in the geometric representation of HGUs and major structural features in the model (Faunt and others, 2004, p. 279). Using the methods in Appendix 2, some observations (table A2-1) had much smaller variance than the equivalent observations in the DVRFS model, and the variance was changed to match the DVRFS model (Claudia Faunt, U.S. Geological Survey, written commun., September 21, 2007).

\section{Water Levels at Discharge Locations}

Water levels at selected discharge locations also were used as observations to provide sensitivity to parameters if the simulated discharge is zero. If a head-dependent discharge

Table 5. Number of observation wells with top and bottom of open interval in each model layer in the numerical groundwater flow model, Great Basin carbonate and alluvial aquifer system study area.

\begin{tabular}{|c|c|c|c|c|c|c|c|c|c|}
\hline & & \multicolumn{8}{|c|}{ Top of well (layer number) } \\
\hline & & 1 & 2 & 3 & 4 & 5 & 6 & 7 & 8 \\
\hline \multirow{8}{*}{ 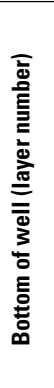 } & 1 & 771 & & & & & & & \\
\hline & 2 & 177 & 145 & & & & & & \\
\hline & 3 & 63 & 43 & 94 & & & & & \\
\hline & 4 & 27 & 22 & 34 & 51 & & & & \\
\hline & 5 & 12 & 3 & 6 & 15 & 23 & & & \\
\hline & 6 & 3 & 0 & 3 & 1 & 4 & 12 & & \\
\hline & 7 & 0 & 1 & 1 & 1 & 0 & 6 & 10 & \\
\hline & 8 & 0 & 0 & 0 & 0 & 0 & 1 & 0 & 0 \\
\hline
\end{tabular}

boundary is not discharging water, changing parameter values does not cause the discharge to change and sensitivity to the parameter is zero. Water levels at these locations, however, do have sensitivity to model parameters.

The altitude used for water-level observations at springs is the minimum of the reported spring altitude or $10 \mathrm{ft}$ below the land surface at the center of the cell. For selected rivers, two points were used as water-level observations, one representing river altitude at a point midway between the gage and the upstream end of the river (the same location where discharge is assumed to start occurring) and one representing the river altitude near the gage. Because the location of discharge along the rivers is not known, these levels generally were not used as observations if the model was simulating at least 50 percent of the observed discharge to the river. The variance assigned to the altitude of discharge points was $1,000 \mathrm{ft}^{2}$, with the exception of large area springs in valleys, which were assigned a variance of $20 \mathrm{ft}^{2}$ because the location and altitude are more certain. These variances are similar to variances in water levels at wells in mountains and valleys, respectively.

\section{Groundwater Discharge and Uncertainty}

Groundwater discharge observations include discharge to ETg, springs, rivers, and lakes. Discharge is considered negative in MODFLOW, and all discharge observations are reported as negative in this report to match model files. A larger discharge, therefore, is a more negative number. The amount of discharge used for each observation and the uncertainty of these observations are discussed in the following sections. In general, discharge data have larger uncertainty than water-level data, largely because of measurement error and because of seasonal or annual changes that are not measured by what are often only one-time measurements or estimates.

\section{Evapotranspiration from Groundwater}

Discharge observations for ETg were developed from data described in table A1-1 and in Heilweil and Brooks (2011, Auxiliary $3 \mathrm{H})$. The observed ETg and adjusted ETg are described in Masbruch and others (2011). Simplifications and grouping made in this regional model included adding some groundwater discharge to springs and rivers to the ETg observation to prevent multiple headdependent boundary conditions in a single model cell (table A1-1). ETg has been extensively studied in the DVRFS; 


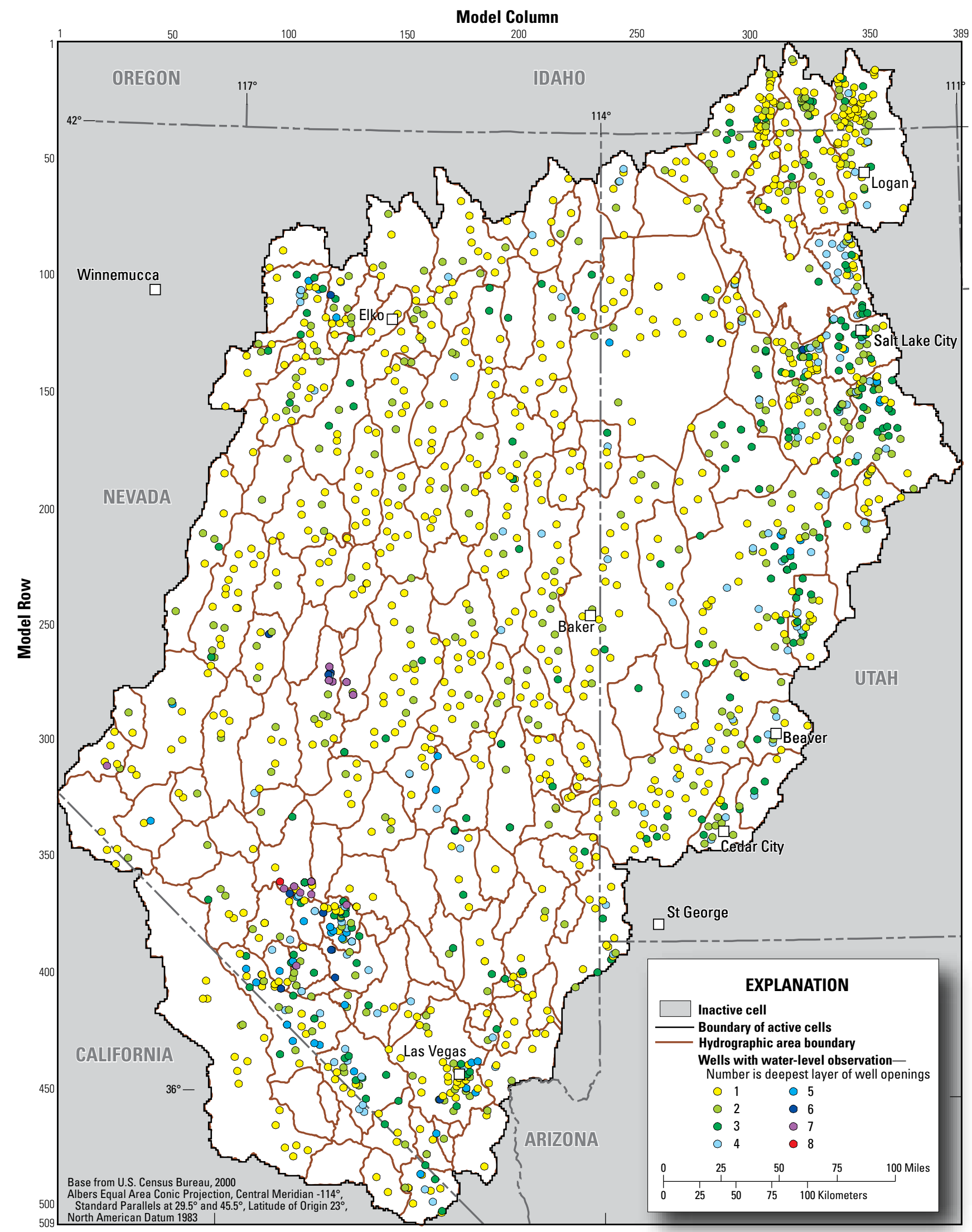

Figure 19. Depth distribution of well openings for water-level observations used in the numerical groundwater flow model, Great Basin carbonate and alluvial aquifer system study area. 
coefficients of variation used for observations of ETg in a transient simulation of the region ranged from 0.1 to 0.71 , and averaged 0.35 (Faunt and others, 2004, table F-4). ETg also was extensively studied in the BARCAS study area; the estimates have a coefficient of variation of about 0.25 (Welch and others, 2007, fig. 34). For simplification, ETg was assumed to have a coefficient of variation of 0.3 for all observations in this model.

\section{Springs}

Discharge observations for springs (table A1-2) were developed from discharge data derived from the USGS NWIS and published reports (table A1-9). In cases where groundwater withdrawals may have affected natural spring discharge, observations are determined by using discharge measurements only from years before major well withdrawals began near the spring. At springs with more than one measurement not thought to be affected by major groundwater withdrawals, the repeated measurements are used to calculate variance and coefficient of variation. The average coefficient of variation of the discharge for these springs was 0.29 ; this coefficient of variation is assumed to apply to all springs with only one discharge measurement.

Multiple springs were sometimes combined into one observation (table A1-2) because (1) they are located in the same model cell; (2) they are located near other springs and at the regional scale of this model, minor variations of discharge in nearby cells is not as important as the total discharge in an area; or (3) the discharge from individual springs is less than $300 \mathrm{gal} / \mathrm{min}$, but the total discharge of multiple nearby springs is greater than $300 \mathrm{gal} / \mathrm{min}$. When springs were combined, the variances were added to determine the new variance; the coefficients of variation, therefore, do not equal the original coefficients of variation.

\section{Rivers}

Baseflow to mountain streams was typically determined by using the minimum reported discharge for the period of record as reported in the NWIS (table A1-4). This simplified approach to estimating baseflow, which was used because of the lack of good hydrograph separation techniques for snowmelt-dominated streams (Masbruch and others, 2011, p. 102), has an error that is difficult to quantify. The gaging station records used for this analysis are typically rated "good" to "fair"; about 95 percent of the daily discharges are within 10 to 15 percent of the true discharge (Novak, 1985, p. 65). The amount of that flow that is groundwater discharge or the annual amount of groundwater discharge, however, is only an estimate. Groundwater discharge to rivers, therefore, was assumed to have a coefficient of variation of 0.25 , which is similar to the coefficient of variation for discharge to springs and ETg. If the simulated river is between gages, the variance of flow at each gage was determined and the variances added to obtain the variance for the observation between the gages. In some areas, mountain streams were combined in observations; in that case the variances were added to determine the variance for the observation.

Groundwater discharge to basin rivers was determined from gaging station records and previous reports (table A1-5). Because the amounts of diversions and return flows are not known for these rivers, the amounts may not be accurate and a coefficient of variation of 0.25 was assumed to be consistent with other discharge observations.

\section{Lakes}

Discharge to lakes was estimated in Heilweil and Brooks (2011, Auxiliary 3K), and the coefficient of variation was assumed to be 0.3 to be consistent with discharge to ETg and springs. Not enough data exist to determine the coefficient of variation for each observation. The five observations are listed in table A1-8. Groundwater discharge to lakes is less than 3 percent of the groundwater budget, and 91 percent of the discharge to lakes occurs to Great Salt Lake and Utah Lake (pl. 1) within the Great Salt Lake (38) groundwater flow system. 


\section{Model Calibration}

The purpose of calibration is to develop a model that reasonably represents groundwater recharge, movement, and discharge, and reasonably matches measured water levels. During calibration, various aspects of the model were changed to make differences between simulated and observed water levels and discharge acceptable for the intended use of the model. To determine the values and distribution of recharge, horizontal hydraulic conductivity, and anisotropy; values of drain and river conductance; and the location and conductances of horizontal flow barriers, model parameters were adjusted to improve the match between observed and simulated conditions. Calibration relied on nonlinear regression using UCODE_2005 (Poeter and others, 2008) and on manual calibration using sensitivity analysis and other statistics generated by UCODE_2005.

Given the regional scale of this model, calibration attempts were concentrated to reduce unweighted residuals to $200 \mathrm{ft}$ for water levels and 30 percent of flow for discharge observations. Calibration criteria often state that the root-mean-square error of the residuals should be less than 10 percent of the range of observations (Ely and Kahle, 2004, p. 41); using this criterion for water levels in the study area, the acceptable error could be as large as $1,000 \mathrm{ft}$, which seems unreasonable. The conceptual water-level gradient, however, can be as steep as about $500 \mathrm{ft} / \mathrm{mi}$ (Heilweil and Brooks, 2011, pl. 2), and an error that is only about one-half of that seems reasonable. Discharge observations are typically considered to be accurate only within about 30 percent because (1) discharge is often estimated, not measured; (2) discharge to evapotranspiration is difficult to quantify; (3) seasonal and annual variations of most springs typically are not known; and (4) baseflow calculations are difficult in snowmelt-dominated streams or in valley rivers with diversions and inflows.

\section{Methods}

Nonlinear regression was used to find parameter values that produced simulations that best fit the observations. The fit between model simulated values and associated observations was quantified by using a weighted least-squares objective function (Hill and Tiedeman, 2007, p. 27-28); nonlinear regression adjusted the parameter values to minimize the sum of squared weighted residuals. The weighting used in the objective function is based on the analysis of observation errors presented in the "Observations Used in Model Calibration" section of this report. For the GBCAAS model, 176 parameters are used, of which 164 were estimated at some point during the calibration process.

Uncertain aspects of the hydrogeology were evaluated by constructing models with different hydraulic-property and recharge distributions. These models were evaluated through sensitivity analysis and other statistics using methods discussed in the following sections.

\section{Composite Scaled Sensitivity}

Composite scaled sensitivity (CSS) was used to evaluate whether available observations provide adequate information to estimate each parameter (Hill and others, 2000, p. 96), to provide an overall view of the average amount that simulated values change given a 1-percent change in the parameter (Hill and Tiedeman, 2007, p. 50), and to determine if the number of model parameters could be increased or reduced.

The relative magnitude of CSS values was used to assess whether additional parameters could be estimated. A relatively large CSS value indicated that observations contain enough information to represent that aspect of the system in more detail by using additional parameters. A relatively small CSS value (about two orders of magnitude less than the largest CSS value) indicated that the observations provide insufficient information with which to estimate the parameter (Hill and Tiedeman, 2007, p. 50). Parameters with small CSS values generally were assigned a fixed value or were joined with another parameter in this model.

\section{Parameter Correlation Coefficient}

Parameter correlation coefficients (PCC) were used to evaluate whether model parameters could be estimated uniquely by regression (Hill and Tiedeman, 2007, p. 53). A correlation coefficient having an absolute value close to 1.00 indicates that the two parameters involved likely cannot be estimated uniquely. Generally, absolute values greater than 0.95 are cause for concern, but values as small as 0.85 can affect the uncertainty of parameter estimates. If parameter correlation was high, the value of the correlated parameter with the smallest CSS was assigned a value and not adjusted during regression.

\section{Influence Statistics}

The RESIDUAL_ANALYSIS program (Poeter and others, 2008) calculates additional statistics that are useful in finding observation errors and model construction errors, and in highlighting changes in model construction that lead to more realistic values of model parameters. The DFBETAS statistics identified observations that were influential in the estimation of each parameter (Poeter and others, 2008, p. 181). If nonlinear regression led to unreasonable parameter values, or if regression statistics indicated that a parameter change improved fit in one part of the model but made fit worse in other areas, these statistics were used to identify observations that may be incorrect and areas in which to create different parameters. A few water-level observations were removed from the model after closer analysis indicated they may be perched or otherwise not represent the steady-state regional flow system. Nine other observations (pl. 1) use a reduced weight because they have large DFBETAS statistics for several model parameters. The reasons for this influence could not be determined, but reduced weight was necessary to achieve a numerically stable regression. 


\section{Evaluation of Parameter Estimates}

During calibration, the regressed values of parameters were compared to realistic values. If the model represents the physical system adequately, and the observations used in the regression provide substantial information about the parameters being estimated, estimated parameter values should be realistic. Unrealistic estimated parameter values can indicate model error (Hill and Tiedeman, 2007, p. 80), and were used to guide model changes and further calibration.

\section{Reasonable Ranges and Uncertainty}

Horizontal hydraulic conductivity is discussed in the "Hydrogeologic Framework" section of this report. The 95-percent confidence interval (table 3 ) is considered the reasonable range of horizontal hydraulic conductivity for each HGU. Vertical anisotropy of the UBFAU is likely to be significant because of the layered nature of basin-fill sediments (Thomas and others, 1989, p. E13-E14), with the vertical conductivity being less than the horizontal conductivity (anisotropy ratio greater than 1). The reasonable range for vertical anisotropy of the UBFAU in this model is considered to be 1 to 5,000 (table 6); other numerical simulations have used 10 to 1,000 (Ely and Kahle, 2004, table 2) and 5,000 (Faunt and others, 2004, table F-13). Fractures, folding, and dip of strata in consolidated rocks, and ash flows and tuff in the LBFAU, create vertical anisotropy that is measurable at the local reservoir scale given sufficient data (Chilingarian and others, 1996; Widarsono and others, 2006). However, at the regional scale the three-dimensional permeability field is poorly known, owing to sparse information from widelyspaced well data. The reasonable range of vertical anisotropy of consolidated rock in this model is considered to be 0.1 to 10 (table 6). Faunt and others (2004, table F-13) used values of 1.0 to 2.2. The reasonable range for HFB conductance is assumed to be $5 \times 10^{-13}$ to 0.02 (table 6). This range was calculated assuming that the conductance of HFBs has the same standard deviation as horizontal hydraulic-conductivity value of the USCU, NCCU, and TNCCU, and that the initial value was the same as the minimum hydraulic-conductivity value of the USCU, NCCU, and TNCCU (tables 3 and 6).
The conceptual model of the GBCAAS indicates that BCM recharge may not be correct in all areas and may need to be multiplied by values ranging from 0.29 to 2.25 in different areas (Masbruch and others, 2011, fig. D-8). This range is used as the reasonable range of values for recharge parameters (table 6). Because the initial ETg conductance was derived to be proportional to the conceptual ETg rate (see "Boundary Conditions" section of this report), the parameter is a multiplier of the conceptual rate. The average coefficient of variation of 0.3 for ETg observations equates to a 90-percent confidence interval of 0.5 to 2.0 times the observed value. The reasonable range for ETg parameters, therefore, is 0.5 to 2.0. The conductance of drains representing springs and the conductance of rivers are assumed to have the same standard deviation of the log values as the horizontal hydraulic conductivity of the UCAU, LCAU, and TLCAU (tables 3 and 6).

\section{Confidence Intervals}

The linear 95-percent confidence intervals for parameters determined by UCODE_2005 (Poeter and others, 2008) were used to evaluate if a parameter value was reasonable. A linear 95-percent confidence interval for a parameter estimate that excludes reasonable values indicates model bias, misinterpreted data for the parameter or observations, or incorrect model construction (Hill and Tiedeman, 2007, p. 141). An estimated parameter value that falls outside the range of reasonable values, but for which the confidence interval includes reasonable values may or may not indicate similar problems. Linear confidence intervals often are sufficient for this analysis (Hill and Tiedeman, 2007, p. 141), even if the model is nonlinear. Some observations were removed from the model after this analysis indicated unreasonable parameter values that were caused by a single observation; if more detailed information about the observation indicated it may not represent the steady-state regional groundwater flow system, it was removed. Model zonation and parameters were changed if this analysis indicated incorrect model construction.

In addition to assessing possible model error, confidence intervals for estimated parameters also were used to assess whether all estimated parameters were warranted (Hill and

Table 6. Estimates of properties describing parameter values for recharge, drains, rivers, horizontal-flow barriers, and vertical anisotropy in the numerical groundwater flow model, Great Basin carbonate and alluvial aquifer system study area.

[Approximate standard deviation of recharge: calculated to get 90-percent confidence intervals around the estimated value that include the minimum and maximum estimated values. Approximate standard deviation of all other parameters: standard deviation of the log estimated values. ETg, evapotranspiration from groundwater]

\begin{tabular}{|c|c|c|c|c|c|}
\hline \multirow[b]{2}{*}{ Parameter type } & \multirow[b]{2}{*}{ Parameter units } & \multicolumn{4}{|c|}{ Parameter value } \\
\hline & & Initial value & $\begin{array}{l}\text { Minimum reasonable } \\
\text { range }\end{array}$ & $\begin{array}{c}\text { Maximum } \\
\text { reasonable range }\end{array}$ & $\begin{array}{c}\text { Approximate standard } \\
\text { deviation }\end{array}$ \\
\hline $\begin{array}{l}\text { Vertical anisotropy of lower basin fill and } \\
\text { consolidated rock }\end{array}$ & unitless & 1.00 & 0.10 & 10.00 & 0.50 \\
\hline Vertical anisotropy of upper basin fill & unitless & 10.00 & 1.00 & 5,000 & 1.40 \\
\hline Horizontal-flow barrier conductance & feet per day & $1 \times 10^{-7}$ & $5 \times 10^{-13}$ & 0.02 & 2.70 \\
\hline Recharge multiplier & unitless & 1.00 & 0.29 & 2.25 & 0.50 \\
\hline ETg conductance multiplier & unitless & 1.00 & 0.50 & 2.00 & 0.15 \\
\hline Drain conductance & feet per day & 1.00 & 0.0003 & 3,373 & 1.80 \\
\hline River conductance & feet per day & 1.00 & 0.0003 & 3,373 & 1.80 \\
\hline
\end{tabular}


Tiedeman, 2007, p. 328). For example, if the confidence intervals overlapped for two parameters representing the hydraulic conductivity of rock types of similar hydraulic properties, the rocks would be represented by a single hydraulic-conductivity parameter. If the simulation using fewer hydraulic-conductivity parameters yielded a similar model fit to the observations, the available observations are insufficient to distinguish between the models. Thus, the model with more hydraulicconductivity parameters represents a level of complexity that is not supported by the available data. If model fit deteriorated significantly, the parameters were not combined. For nonlinear models, the linear intervals are approximate, but are often effective in identifying likely parameter combinations (Hill and Tiedeman, 2007, p. 328).

\section{Use of Insensitive Parameters and Prior Information}

Some model parameters were divided and refined in this model even though the composite scaled sensitivities were not high. This achieved a better match between simulated and observed water levels or between simulated and observed discharge in some locations. Because model observations provide little information about these insensitive parameters, it is difficult to assess how well they are estimated in the simulation. Many of the parameters with the lowest composite scaled sensitivities are HFB parameters, which have a low conductance value, or HK parameters that have a low hydraulic-conductivity value. Hill and Tiedeman (2007, p. 43) state that measures of importance (including sensitivity) of the value of parameters with extremely small values of conductivity will tend to be small. The value of these parameters was typically set during regression to avoid numerical instability of the regression.

To encourage understanding of the information that is available from observations, model parameters were not constrained during model construction and calibration, and prior information was not used to keep regressed values close to observed values. Because observations are more accurate than information on parameter values, observations were emphasized in model calibration (Hill and Tiedeman, 2007, p. 289).

For final analysis of sensitivity, parameter correlation, parameter confidence intervals, and prediction uncertainty, prior information was used for eight parameters (table 7) that could not be estimated by the model with a standard deviation lower than the observed standard deviation as listed in tables 3 and 6. Prior information was used to simulate a realistic degree of uncertainty in these parameters (Hill and Tiedeman, 2007, p. 131).

\section{Adjust Weighting for Discharge Observations}

During early model calibration, regression would often match head observations much closer than it would match discharge observations. Because determining if the conceptual groundwater movement and discharge presented in Heilweil and Brooks (2011) could be simulated with reasonable parameters is as important as matching water levels, the weight of discharge observations was increased in comparison to waterlevel observations. This increased weighting is frequently done, especially for observations that provide unique information (Hill and Tiedeman, 2007, p. 301). In groundwater systems, discharge data provide information that reduces correlation among parameters (Hill and Tiedeman, 2007, p. 302). All discharge observations were given a weight multiplier of 5.0 to force the regression to more closely match these observations. In UCODE_2005 (Poeter and others, 2008), the weight of an observation is the inverse of the variance of the observation. Variance is proportional to the square of the coefficient of variation. Thus, the weight multiplier of 5 changes the coefficient of variation for discharge observations from an average of 0.28 to an average of $0.28 / 5^{1 / 2}$, or 0.12 (table 4 ).

\section{Adjust Altitude of Selected Springs}

During calibration, the spring altitude at selected springs was lowered by as much as $200 \mathrm{ft}$ (table A1-2) in an attempt to simulate observed discharge. Sixteen percent of the drain cells representing springs had the altitude adjusted, but only 8 percent had the altitude adjusted by as much as $200 \mathrm{ft}$.
Table 7. Prior information statistics for selected parameters in the numerical groundwater flow model, Great Basin carbonate and alluvial aquifer system study area.

[Prior value: dimensionless for recharge and evapotranspiration parameters; feet per day for hydraulic conductivity parameter. Standard deviation: of the value for recharge parameters, of the log of the value for hydraulic conductivity and evapotranspiration parameters. Abbreviations: HA, hydrographic area; GWFS, groundwater flow system]

\begin{tabular}{llccl}
\hline \multicolumn{1}{c}{ Parameter type } & Parameter name & Prior value & $\begin{array}{c}\text { Standard } \\
\text { deviation }\end{array}$ & Location \\
\hline Recharge & rch275 & 6.47 & 0.5 & HAs 275, 276, part of 273 \\
Recharge & rch282 & 1.82 & 0.5 & Part of HA 282 \\
Recharge & rch9999 & 0.01 & 0.5 & Various locations \\
Hydraulic conductivity & ucau31hk & 0.0005 & 1.8 & Near Lake Mead \\
Evapotranspiration & et265 & 1.50 & 0.15 & HAs 265 and 266 \\
Evapotranspiration & et268 & 0.986 & 0.15 & HA 268 \\
Evapotranspiration & et_deathval & 2.00 & 0.15 & GWFS 28 and HA 212 \\
Evapotranspiration & et_sevier & 2.22 & 0.15 & Northern part of GWFS 39 \\
\hline
\end{tabular}

\section{Compare Water Levels to Land-Surface Altitude}

During model calibration, the simulated water level in layer 1 was frequently compared to land-surface altitude to ensure that abnormally high simulated water levels were not occurring. These comparisons are not formal observations and do not influence the regressed values of parameters, but regressed values were modified manually if they created areas of water levels more than $200 \mathrm{ft}$ above land surface. 


\section{Model Variations}

During calibration, a number of models were evaluated using MODFLOW-2005 and UCODE 2005. Evidence of model error or data problems was investigated after each model run, and the model fit to water levels and groundwater discharge observations was analyzed. These analyses were used in conjunction with hydrogeologic data to modify and improve the existing conceptual model and observation datasets. Sensitivity and fit statistics were used to determine if model changes, such as re-zoning hydraulic conductivity or recharge parameters, could lead to a better model fit and if additional parameters were warranted on the basis of the information provided by the observations. For example, parameters were divided if the CSS of a parameter was significantly greater than 1.0 and large compared to the CSS of other parameters (Hill and Tiedeman, 2007, p. 328).

The first model used conceptual recharge rates and estimated ETg rates (Masbruch and others, 2011), one value of hydraulic conductivity (HK) for each of the HGUs, one value of vertical anisotropy (VANI) for the UBFAU and one value of VANI for all other units, one value of spring and riverbed conductance, one value of the ETg parameter, no HFBs, and no subsurface inflow or outflow. This model had 24 parameters, including 11 recharge parameters. The multiple recharge parameters were needed to match conceptual recharge multipliers (Masbruch and others, 2011, fig. D-8). Nonlinear regression converged for this model, but resulted in some unreasonable parameter values, did not provide discharge to 121 of 313 discharge observations, reduced the overall groundwater budget to about 60 percent of the estimated budget, and had a standard error of 26.8. This was not considered to be an acceptable representation of the groundwater system. An important statistic from this model is that no parameters had correlations greater than 0.85 , indicating that because most discharge is defined as observations, little correlation exists between recharge and hydraulic conductivity. The composite scaled sensitivities for this version of the model indicated that the observations provide more information about the hydraulic conductivity of the LCAU HGU than about any other hydraulic-conductivity parameter (fig. 20).

Because of the large CSS of hydraulic conductivity of the LCAU HGU, the second version of the model delineated additional hydraulic conductivity zones in the LCAU HGU on the basis of lithological and structural zones (fig. A4-2). The model with LCAU zones delineated had 34 parameters. Nonlinear regression converged for this model, but took more parameters to unreasonable values, did not provide discharge to 114 of 313 discharge observations, reduced the overall groundwater budget to about 60 percent of the estimated budget, and had a standard error of 21.0. This model also was not considered to be an acceptable representation of the groundwater system.

The first two versions of the model indicated that more variety would be needed in the parameters to achieve reasonable matches to water-level and discharge observations. Additional calibration used the methods discussed in the "Model Calibration Methods" section of this report to create new parameters, combine parameters, and add HFBs to the model. Nonlinear regression was then used to estimate the values of parameters with the new model definition. Multiple versions of the model were created using this method.

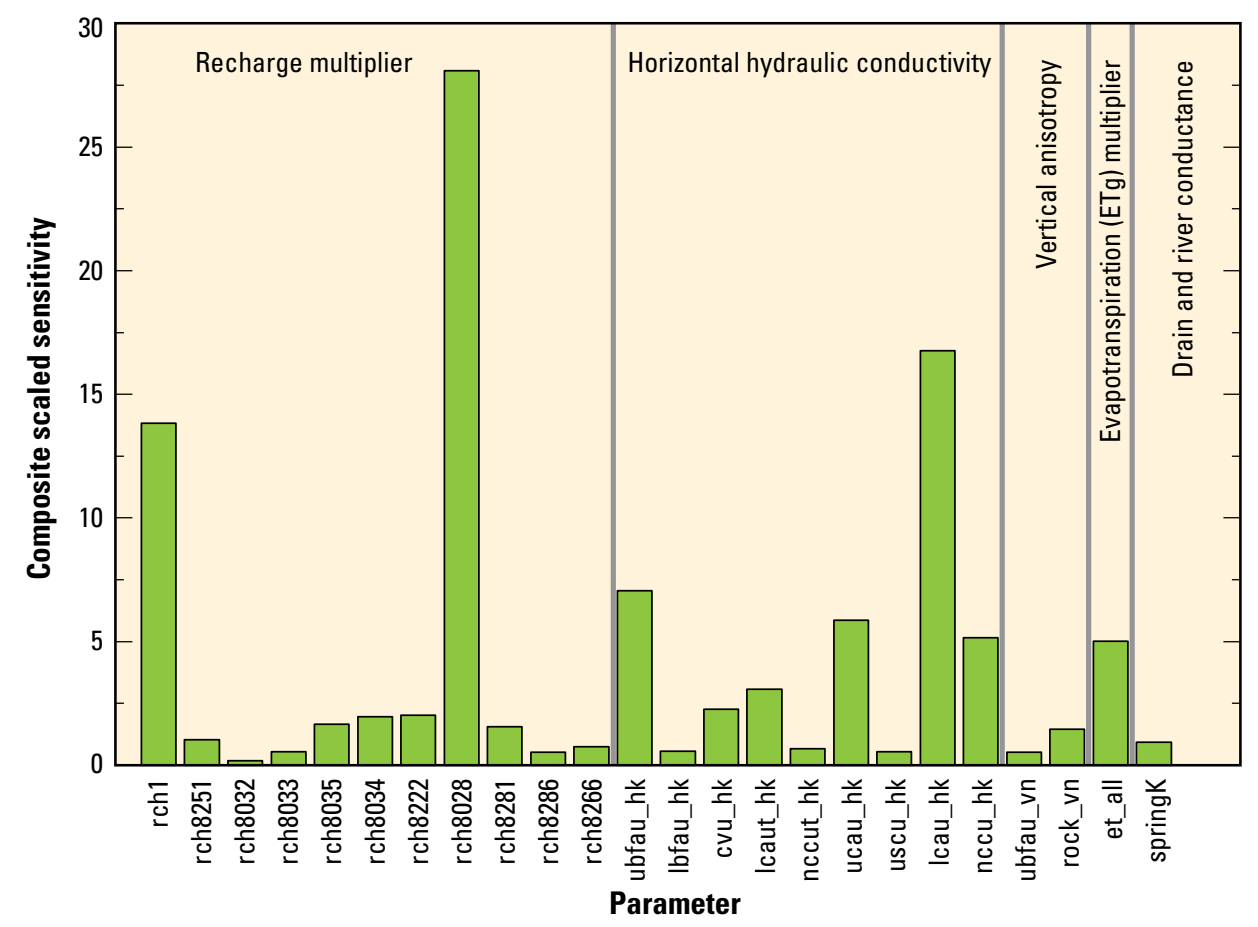

Figure 20. Composite scaled sensitivities for the initial version of the numerical groundwater flow model, Great Basin carbonate and alluvial aquifer system study area. 

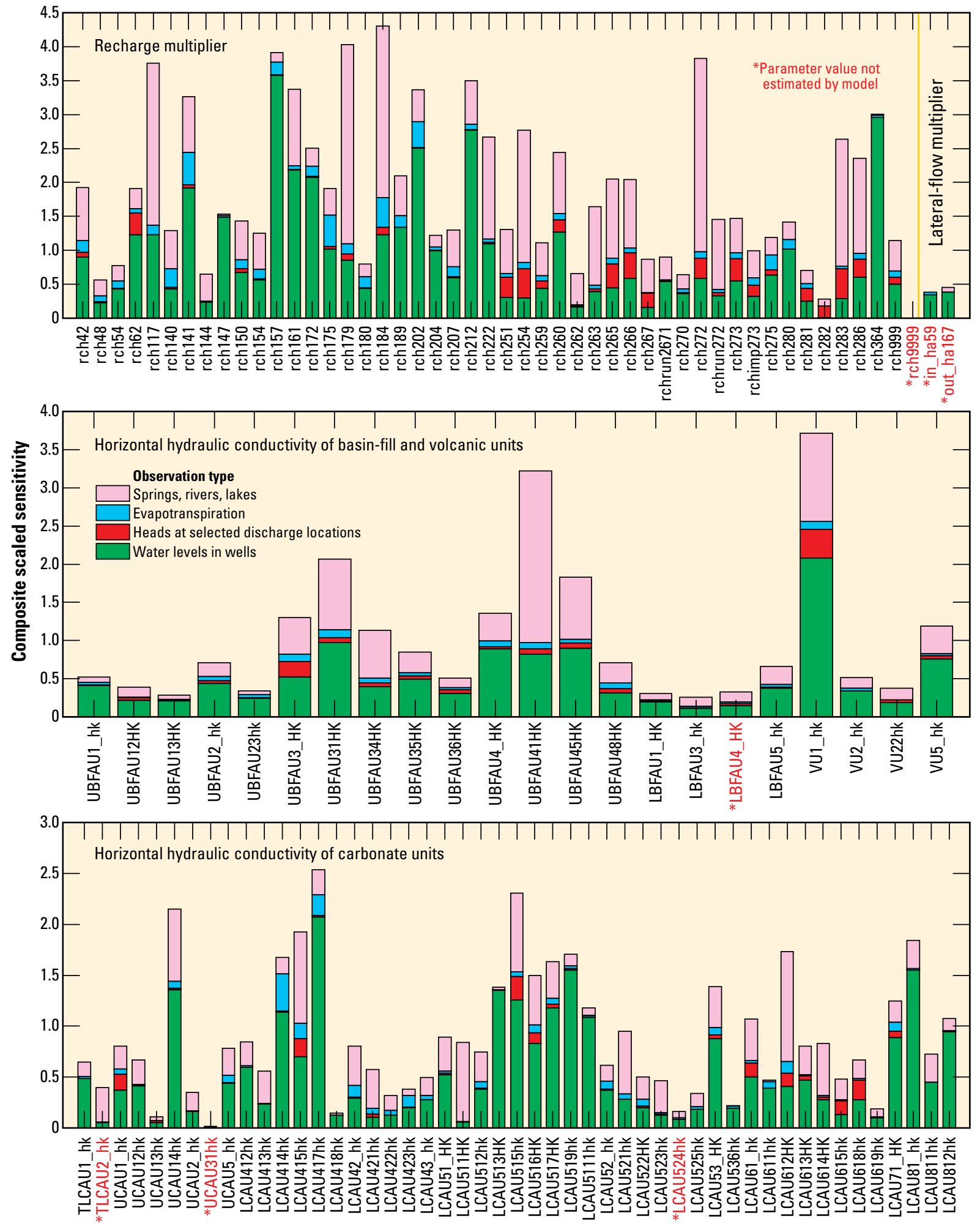

Parameter name

Figure 21. Composite scaled sensitivities for final parameters in the numerical groundwater flow model, Great Basin carbonate and alluvial aquifer system study area. 


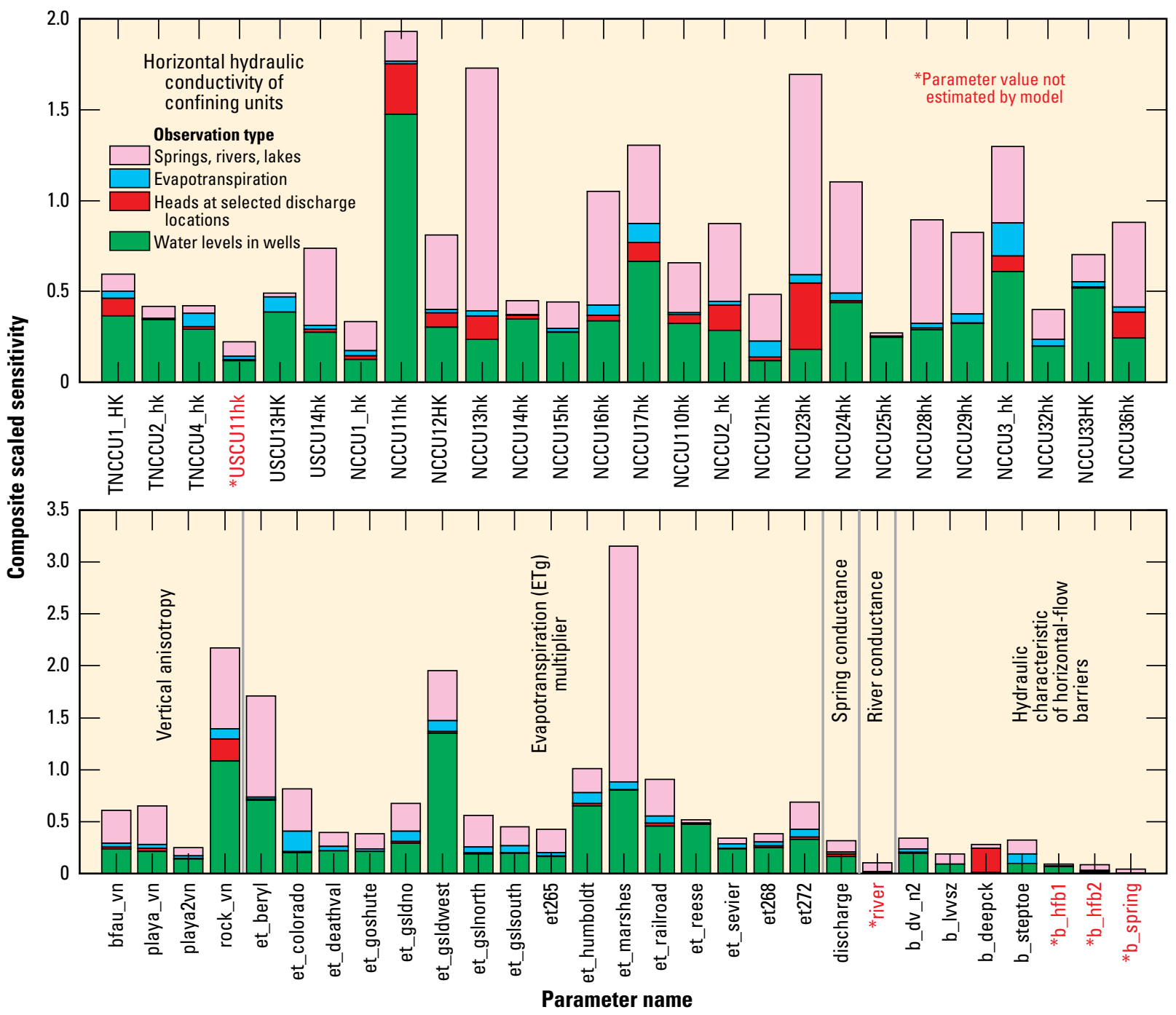

Figure 21. Composite scaled sensitivities for final parameters in the numerical groundwater flow model, Great Basin carbonate and alluvial aquifer system study area.-Continued

\section{Final Calibrated Model and Parameter Values}

In the numerous model variations, most differences were in how recharge and horizontal hydraulic conductivity were represented. Changes to parameters and zones describing vertical anisotropy; conductance of ETg, springs, and rivers; and the minor amounts of lateral inflow and outflow were not as varied. Changes to the representation of HFBs were required and were often dependent on changes in recharge and horizontal hydraulic conductivity. The relative likelihood of the different models was evaluated by considering how simulated water levels and discharge compared to the observations and how parameters compared to reasonable ranges. The model that yielded the best fit with reasonable parameter values and a reasonable number of parameters was retained. The final model has 176 parameters. Most parameter values were estimated at some point during calibration; only 12 were set and never changed by regression (fig. 21). Final model parameters have little correlation, which indicates that the parameters can be determined independently of each other. In the final model, no correlation coefficients exceed 0.95 , and only two pairs (rch117 and et_marshes; rch364 and nccu11hk) exceed 0.85 . Final parameter values are not optimized; further regression by UCODE_2005 changed the values. Analysis of those results, however, indicated that the regression caused problems such as larger areas of simulated water levels above land surface.

Composite scaled sensitivities (fig. 21) indicate that observations of discharge to springs, rivers, and lakes provide as much information about model parameters as do water-level observations. Confidence intervals of parameters (fig. 22) indicate that simulated values provide enough information to constrain most parameters to smaller ranges than the conceptual constraints, and that most parameter values are within reasonable ranges (see "Reasonable Ranges and Uncertainty" section of this report). Because the model is nonlinear, these confidence intervals are not exact, but the 

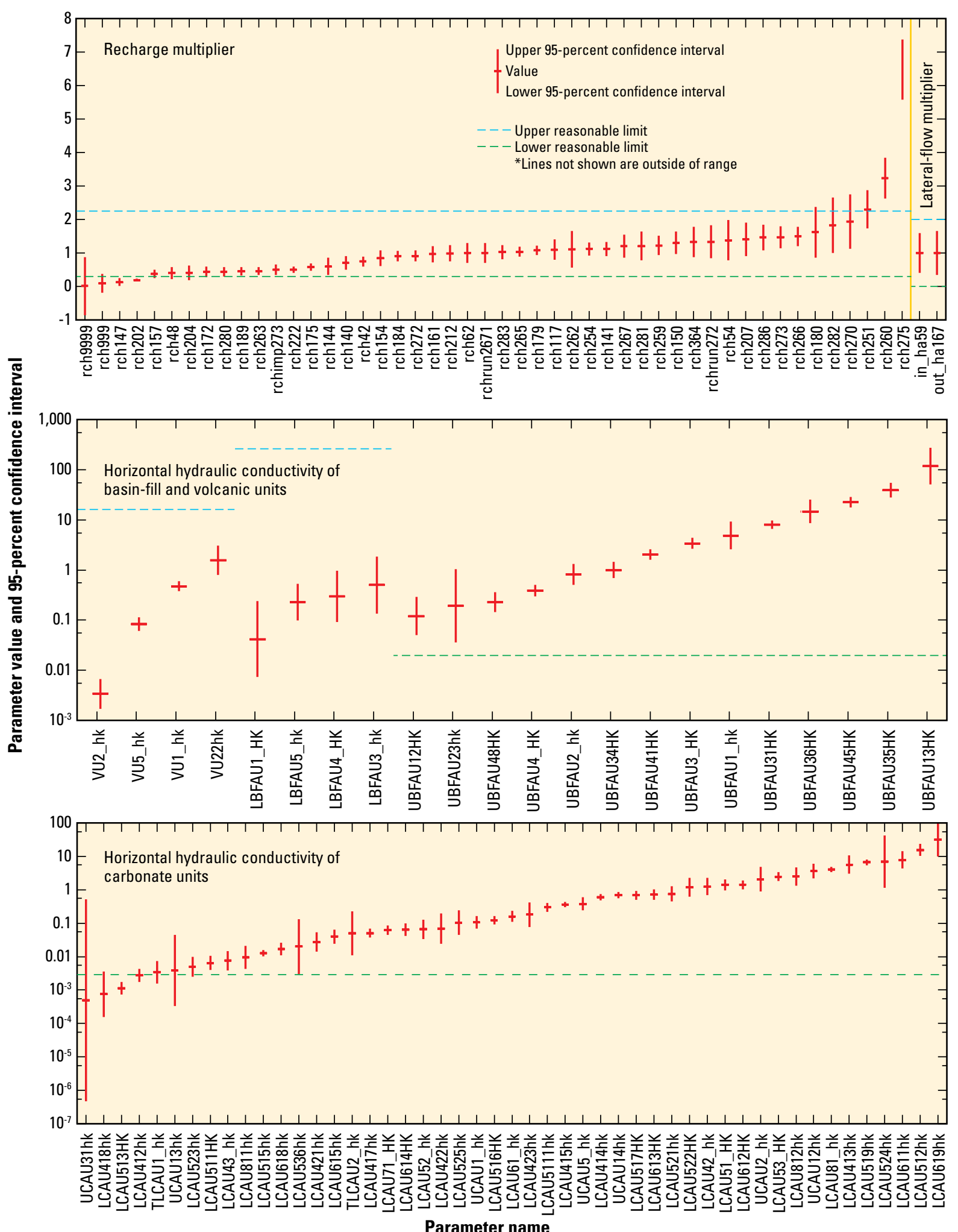

Figure 22. Values and linear confidence intervals of final parameters in the numerical groundwater flow model, Great Basin carbonate and alluvial aquifer system study area. 


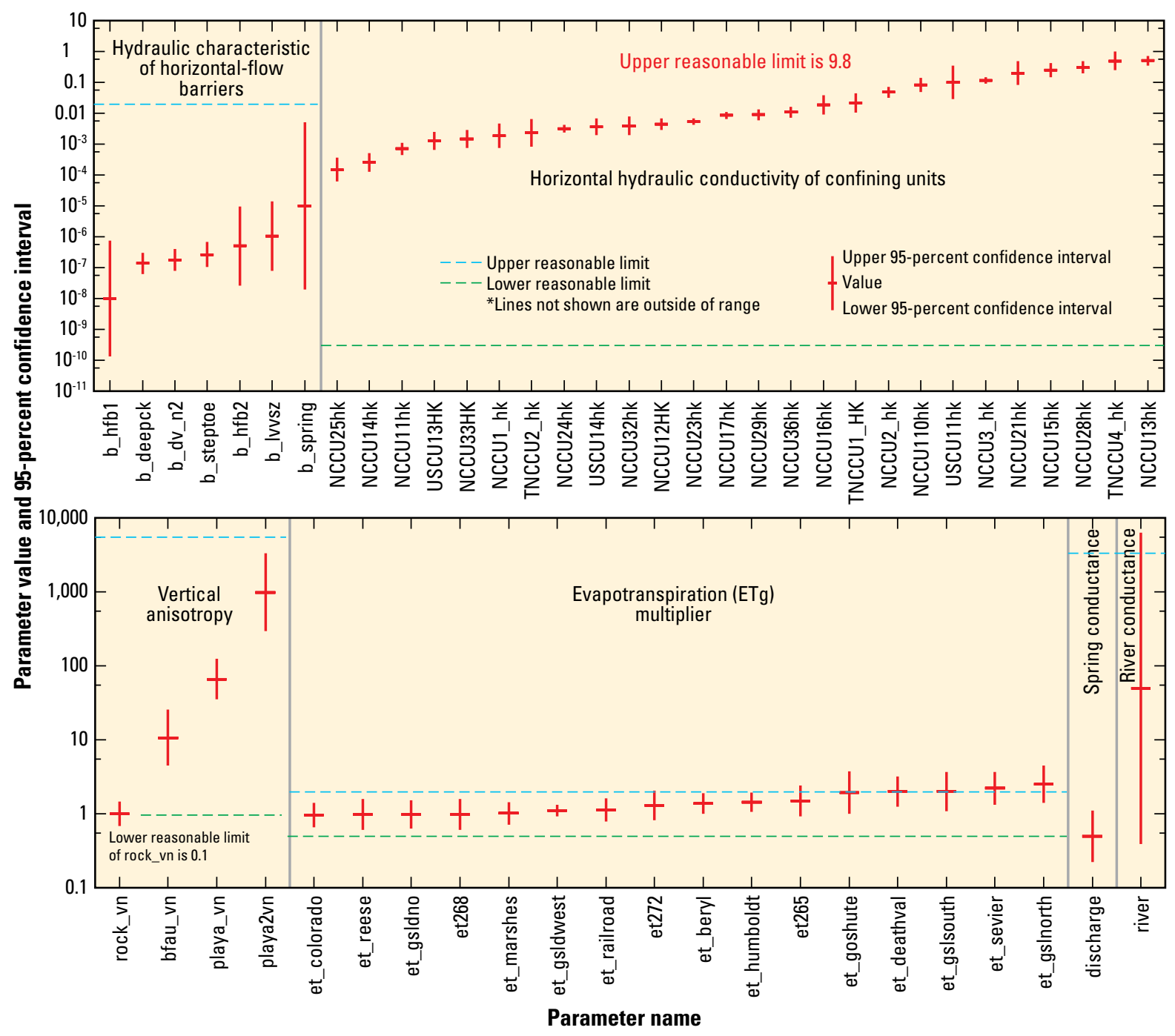

Figure 22. Values and linear confidence intervals of final parameters in the numerical groundwater flow model, Great Basin carbonate and alluvial aquifer system study area.-Continued

error cannot be quantified. Poeter and others (2008, p. 26) state that the 95-percent interval may in reality reflect a 99 - or 50-percent significance level. Christensen and Cooley (1999) state that nonlinear effects can cause the nonlinear intervals to be asymmetric and either larger or smaller than the linear approximations.

\section{Recharge}

In general, simulated equivalents to model observations of water levels and discharge (hereafter referred to as simulated values) in the GBCAAS model are more sensitive to (provide more information about) recharge parameters than to any other parameters (fig. 21). Parameters with high CSS are important to simulated values and were divided into more parameters to represent those aspects of the system in more detail. As a result, 48 recharge parameters are included in the final model (figs. 21, 22, and A4-6; table A4-4). The recharge parameter values are multipliers (fig. 23) of the BCM recharge multiplier arrays described in the "Recharge from Precipitation, Irrigation, and Streams" section of this report. During model calibration, parameter values and zones were changed, and parameters were combined and divided on the basis of composite scaled sensitivities and parameter confidence intervals. Often, the recharge parameters were assigned by HA (fig. A4-6). This provides the variability needed to achieve calibration of this regional model, but should not be considered accurate at the cell-by-cell level. Final simulated recharge rates (the summation of the BCM rates for each type of recharge multiplied by the parameter value) range from 0 to $4.21 \mathrm{ft} / \mathrm{d}$ (fig. 24).

Two recharge zones (the red areas on fig. 23 and zones 999 and 9999 on fig. A4-6) where recharge is reduced to lower values than in the conceptual model (Masbruch and others, 2011, fig. D-8) were added during calibration. These low rates were necessary in selected cells to prevent simulated water levels in layer 1 that were excessive (greater than $200 \mathrm{ft}$ above land surface). This occurred most commonly in areas where 


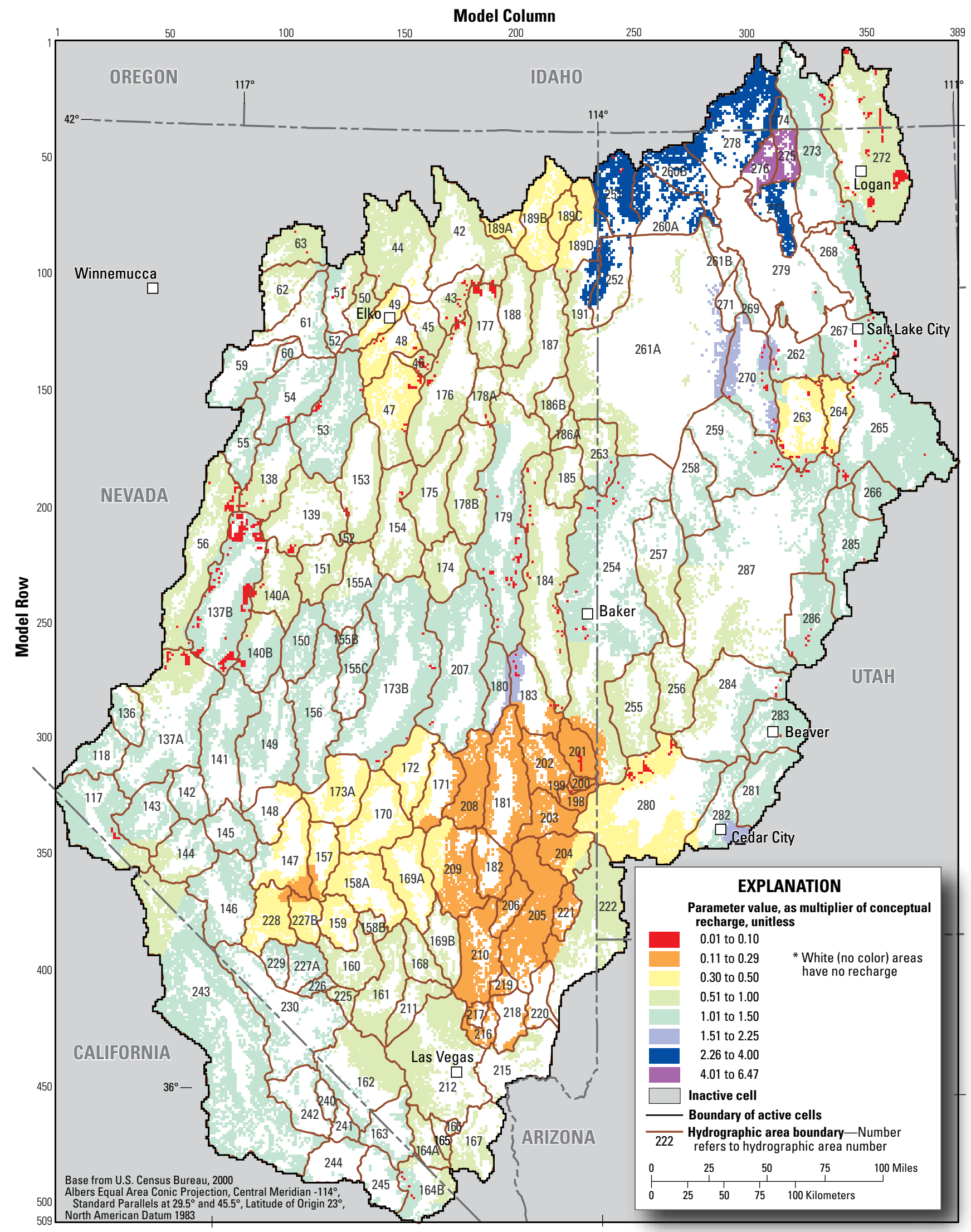

Figure 23. Distribution of parameter values for in-place recharge in the numerical groundwater flow model, Great Basin carbonate and alluvial aquifer system study area. 


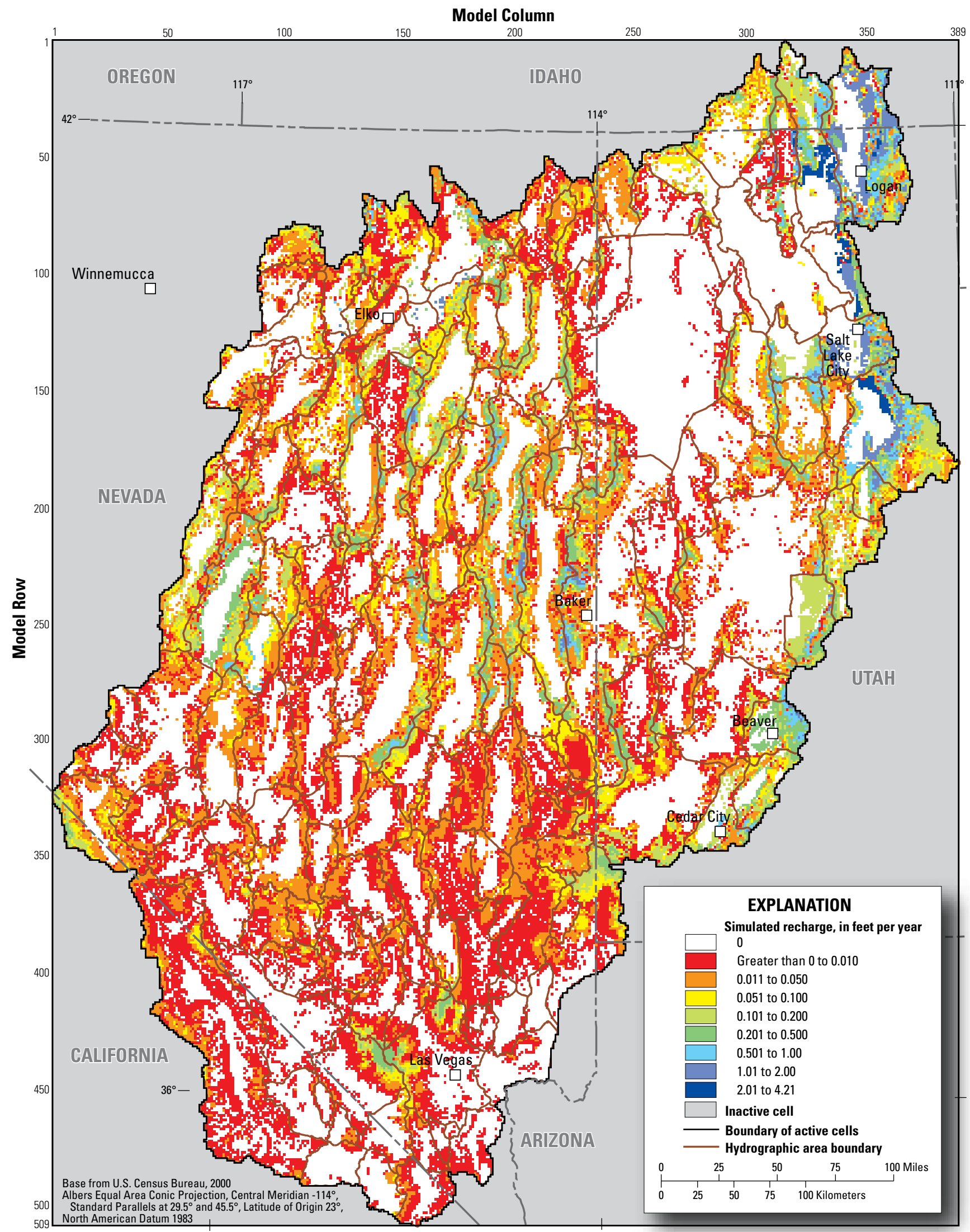

Figure 24. Distribution of simulated recharge in the numerical groundwater flow model, Great Basin carbonate and alluvial aquifer system study area. 
the NCCU underlies more permeable basin fill or consolidated rocks. The BCM calculated recharge on the basis of the permeability of surficial deposits. In some areas where the underlying rocks are less permeable, this infiltration may be horizontally diverted to streams and springs, or it may flow laterally to more permeable areas and then move downward to the groundwater system. This redistribution is accounted for by possibly increasing the parameter that defines recharge in the remainder of the HA where recharge was not reduced. This process is similar to reducing recharge in cells where recharge exceeds hydraulic conductivity (Faunt and others, 2004, p. 324). A few areas in the mountains that appear to be incised stream channels without simulated streams had simulated heads above land surface; recharge parameters rch999 or rch9999 were also used in these cells to reduce water levels. It is possible that groundwater discharge occurs to streams in those areas, but the data do not exist to verify this. The parameter values of these zones were initially set at 0.1 (for parameter rch999) and 0.01 (for parameter rch9999) and did not change during calibration (fig. 22; table A4-4).

As indicated by composite scaled sensitivities and linear confidence intervals, the simulated values provide enough information to estimate most of the 48 recharge parameters (figs. 21 and 22). The simulated values provide enough information to constrain the estimates of recharge more than the conceptual constraints (table 6) and UCODE_2005 calculates a standard deviation of less than the estimated standard deviation (0.5) for 45 of the parameters. For the other three parameters (table 7), prior information was used in UCODE_2005 to calculate the statistics presented in this report. With the exception of the two parameters (rch999 and rch9999 discussed above) used to reduce recharge in selected cells, two parameters (rch147 and rch202) have values below the reasonable limit of 0.29 and three $(\mathrm{rch} 251, \mathrm{rch} 260, \mathrm{rch} 275)$ have values above the reasonable limit of 2.25 (fig. 22). Of those five, only parameter rch 251 has confidence intervals that overlap the reasonable values.

One area in which a recharge parameter with a small value was estimated is the area around and north of Muddy River Springs Area (HA 219; fig. 23). In the conceptual model, the $\mathrm{BCM}$ recharge in this area was multiplied by 0.29 (Masbruch and others, 2011, fig. D-8) to achieve a better balance between recharge and discharge, but many HAs in the area have little or no discharge and recharge exceeds discharge (Masbruch and others, 2011, fig. D-20). In the numerical model, the recharge parameter of 0.19 is lower than in the conceptual model because the model is balancing recharge and discharge in the surrounding basins. The other recharge parameter with a small value (0.13) applies to a small area near the southern part of Gold Flat (HA 147; fig. 23).

The area in which recharge parameters with large values are estimated is in northwestern Utah (fig. 23). In the conceptual model, the BCM recharge in Curlew Valley (HA 278) was multiplied by 2.25 (Masbruch and others, 2011, fig. D-8) to achieve a better balance between recharge and discharge, but many HAs in the area have more discharge than recharge (Masbruch and others, 2011, fig. D-20). In the numerical model, the recharge multiplier is higher than in the conceptual model because the model is balancing recharge and discharge in the surrounding basins, resulting in parameters of $2.3,3.2$, and 6.47 .

\section{Horizontal Hydraulic Conductivity}

Horizontal hydraulic-conductivity parameters were assigned by using the zonation capability of the HUF Package (Anderman and Hill, 2000). Model zones are used to define areas with the same simulated properties within individual HGUs. Initially, hydrogeologic evidence was used to define model zones within the HGUs (Appendix 4; Sweetkind and others, 2011a). A parameter defining the horizontal hydraulic conductivity was associated with each zone. During calibration, however, it became apparent that this zonation does not provide enough variability in hydraulic conductivity to achieve adequate matches to observations. Additional zones, therefore, were delineated that split the original HGU zones into subzones (Appendix 4). For instance, a model zone may include only part of LCAU zone 51 (fig. A4-2), but does not include any part of zone 52. This is consistent with Sweetkind and others (2011a, p. 19) in that the original HGU zones are intended to be a geologically based starting point for further refinement of horizontal hydraulic conductivity by the use of groundwater modeling. The delineation of these zones was mostly dependent on CSS and DFBETAS statistics representing the ability and the need to define additional parameters.

A final set of 97 parameters defining horizontal hydraulic conductivity was used to calibrate the model (tables A4-1 to A4-3). Geologic descriptions, model zones, and parameter names, values, and statistics for horizontal hydraulic conductivity for the nine HGUs are listed in Appendix 4. Maps showing the distribution of simulated hydraulic conductivity in each HGU are included in the following sections, and maps showing the distribution of parameter zones are included in Appendix 4. During calibration, in order to reduce the number of parameters, relatively insensitive parameters were combined with parameters of similar value. As a result, in some cases lithologies from different HGUs and different geologic zones were grouped into one parameter. The variability in simulated hydraulic conductivity is adequate to achieve calibration of this regional model but should not be considered accurate at a cell-by-cell level. The zone boundaries and parameter values may not be unique; different zonation and values could yield a model with approximately an equally good fit to model observations.

\section{Non-Carbonate Confining Unit (NCCU) and Thrusted Non- Carbonate Confining Unit (TNCCU)}

The NCCU represents low-permeability Precambrian siliciclastic formations, is locally exposed in mountain ranges, and underlies most of the study area (Sweetkind and others, 
2011a). Simulated values (simulated equivalents of the observations) provide good information about the hydraulic conductivity of the NCCU (fig. 21), and 20 parameters (fig. A4-1) with values ranging from 0.00015 to $0.5 \mathrm{ft} / \mathrm{d}$ define it in the model (fig. 25; table A4-1). The TNCCU is more limited in area, and the simulated values provide less information about it than about the NCCU (fig. 21). Only three parameters with values ranging from 0.0023 to $0.5 \mathrm{ft} / \mathrm{d}$ are defined (fig. 26; table A4-1). The values of all parameters for hydraulic conductivity in the NCCU and TNCCU are within the reasonable range (fig. 22). The simulated values provide enough information to constrain the estimates of hydraulic conductivity of these units to within smaller ranges than the conceptual constraints. The standard deviation calculated by UCODE_2005 is less than the observed standard deviation of 2.7 on the log values of the parameters (tables 3 and A4-1).

\section{Lower Carbonate Aquifer Unit (LCAU) and Thrusted Lower Carbonate Aquifer Unit (TLCAU)}

The LCAU represents a thick succession of predominantly carbonate rocks, is prominently exposed in the mountain ranges, and is present beneath many of the valleys (Sweetkind and others, 2011a, p. 20). Simulated values provide good information about the hydraulic conductivity of the LCAU (fig. 21), and 40 parameters (fig. A4-2C; table A4-2) with values ranging from 0.00075 to $32 \mathrm{ft} / \mathrm{d}$ define it in the model (fig. 27). The values of three of the parameters (lcau412hk, lcau $418 \mathrm{hk}$, and lcau $513 \mathrm{hk}$ ) for hydraulic conductivity of the LCAU are less than the lower 95-percent confidence interval of $0.003 \mathrm{ft} / \mathrm{d}$ for observed values, but are greater than the minimum observed value of $0.0003 \mathrm{ft} / \mathrm{d}$ (fig. 22; tables 3 and A4-2). Only parameter lcau $513 \mathrm{hk}$ has a 95 -percent confidence interval that does not include the reasonable range. Two of the parameters (lcau412hk and lcau418hk) with low values represent the hydraulic conductivity of carbonate rocks in areas where tectonic extension may have disturbed the continuity of the carbonate units (fig. A4-2C). The other parameter (lcau513hk) with a low value occurs in carbonates that should have moderate hydraulic conductivity, but it has limited area (fig. A4-2C) and was needed to simulate steep gradients or to reduce discharge in downgradient areas. The simulated values provide enough information to constrain the estimates of hydraulic conductivity of this unit to within smaller ranges than the conceptual constraints. The standard deviation calculated by UCODE_2005 for all parameters in this HGU is less than the observed standard deviation of 1.8 on the log values of the parameters (tables 3 and A4-2).

The TLCAU is limited in area, and the simulated values provide less information about hydraulic conductivity of this unit than they do about the hydraulic conductivity of the LCAU (fig. 21). Only two parameters are defined for this HGU, with values of 0.0034 and $0.05 \mathrm{ft} / \mathrm{d}$ (fig. 28; table A4-2); both values are within the reasonable range (fig. 22). The simulated values provide enough information to constrain the estimates of hydraulic conductivity of the TLCAU to within smaller ranges than the conceptual constraints. The standard deviation calculated by UCODE_2005 is less than the observed standard deviation of 1.8 on the log values of the parameters (tables 3 and A4-2).

\section{Upper Siliciclastic Confining Unit (USCU)}

The USCU is limited in area and the simulated values provide little information about hydraulic conductivity of the USCU (fig. 21); only three parameters ranging in value from 0.0013 to $0.1 \mathrm{ft} / \mathrm{d}$ are defined (fig. 29; table A4-1). The simulated values provide enough information to constrain the estimates of hydraulic conductivity of the USCU to within smaller ranges than the conceptual constraints. The standard deviation calculated by UCODE_2005 is less than the observed standard deviation of 2.7 on the $\log$ values of the parameters (tables 3 and A4-1).

\section{Upper Carbonate Aquifer Unit (UCAU)}

The UCAU is widely distributed and the simulated values provide enough information about the hydraulic conductivity of the UCAU (fig. 21) to define seven parameters (fig. A4-3; table A4-2) with values ranging from 0.0005 to $3.63 \mathrm{ft} / \mathrm{d}$ (fig. 30). One parameter (ucau31hk) has a value that is less than the lower 95 -percent confidence interval of $0.003 \mathrm{ft} / \mathrm{d}$ for observed values, but is greater than the minimum observed value of $0.0003 \mathrm{ft} / \mathrm{d}$ (fig. 22; tables 3 and A4-2) and has confidence intervals that include the reasonable range. This parameter is used in a very small area to create the steep gradient on the west side of Lake Mead and to reduce discharge to Lake Mead (fig. A4-3). The sensitivity of observations to this parameter is too low for regression to be used; the value was assigned, and prior information is used to constrain the parameter for the final sensitivity and confidence-interval statistics in this report (table 7). Hill and Tiedeman (2007, p. 43) state that measures of importance (including sensitivity) of the values of parameters with extremely small values of conductivity will tend to be small. The simulated values provide enough information to constrain the estimates of the other parameters to within smaller ranges than the conceptual constraints. The standard deviation calculated by UCODE_2005 is less than the observed standard deviation of 1.8 on the log values of the parameters (tables 3 and A4-2).

\section{Volcanic Unit (VU)}

The VU is widely distributed and simulated values provide enough information about the hydraulic conductivity of the VU (fig. 21) to define four parameters with values ranging from 0.0034 to $1.6 \mathrm{ft} / \mathrm{d}$ (fig. 31 ; table A4-3). The values of all parameters in this HGU are within the reasonable range (fig. 22). The simulated values provide enough information to constrain the estimates of the parameters to within smaller ranges than the conceptual constraints. The standard deviation calculated by UCODE_2005 is less than the observed standard deviation of 1.4 on the $\log$ values of the parameters (tables 3 and A4-3). 


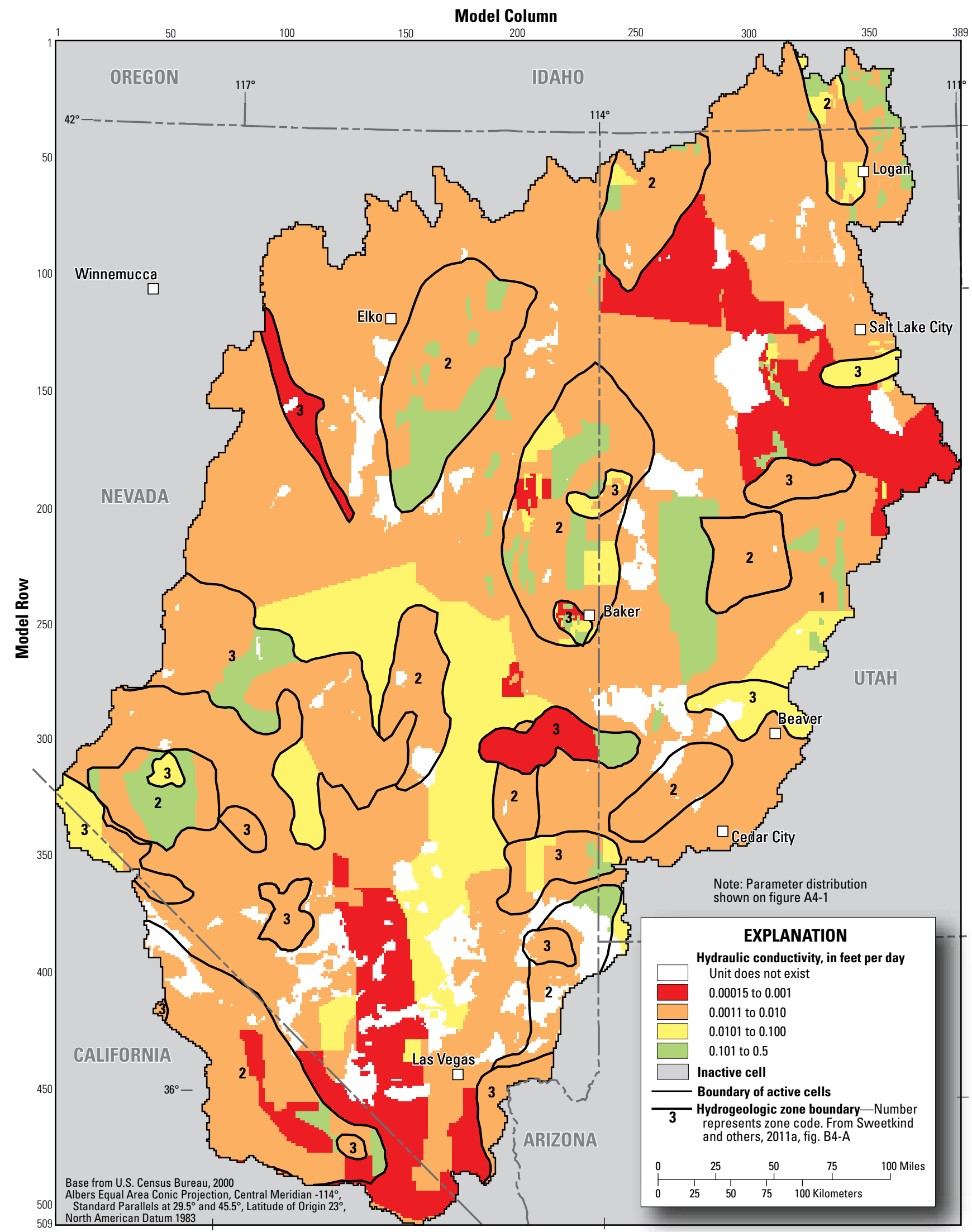

Figure 25. Distribution of hydraulic conductivity of the non-carbonate confining unit (NCCU) in the numerical groundwater flow model, Great Basin carbonate and alluvial aquifer system study area. 


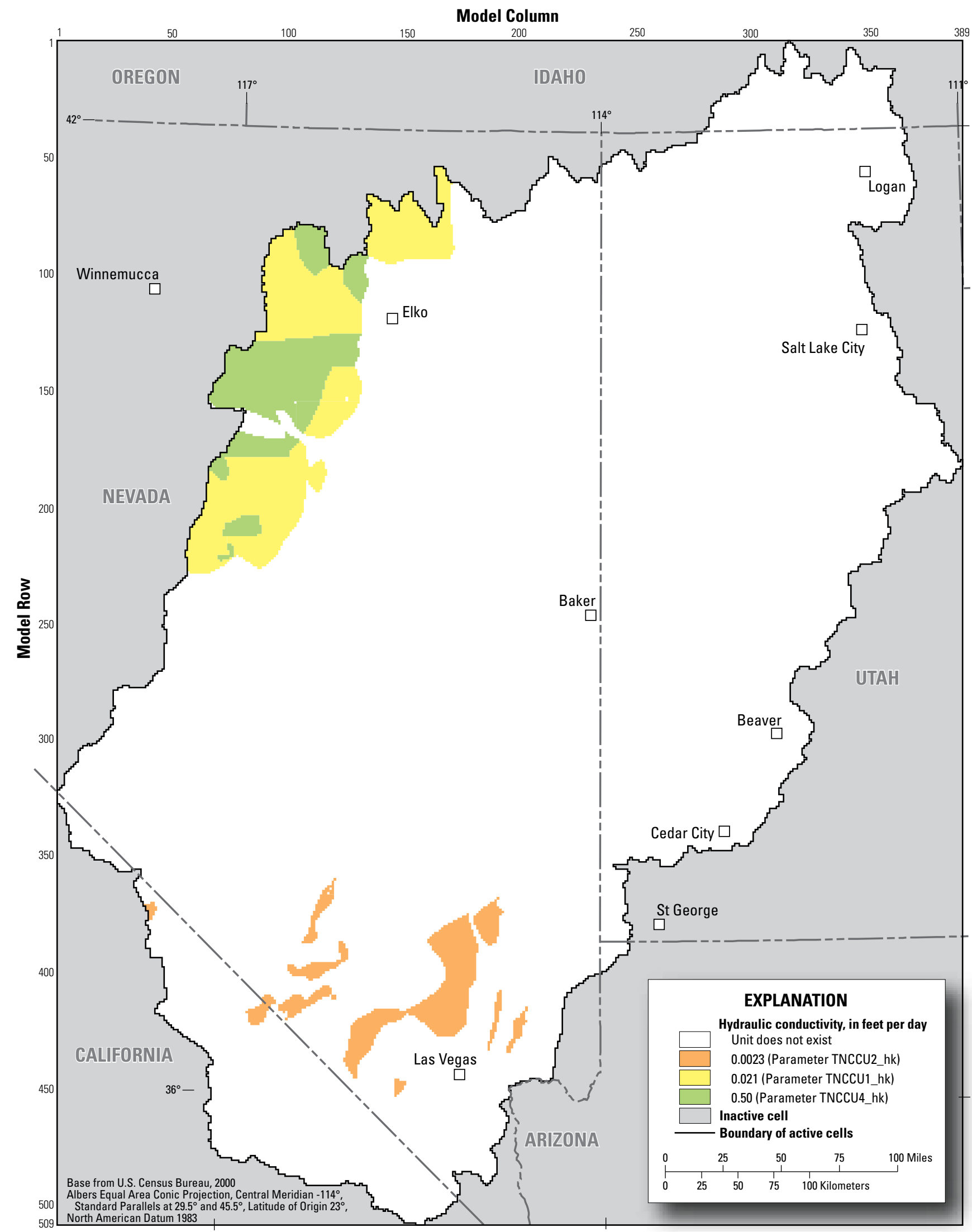

Figure 26. Distribution of hydraulic conductivity of the thrusted non-carbonate confining unit (TNCCU) in the numerical groundwater flow model, Great Basin carbonate and alluvial aquifer system study area. 


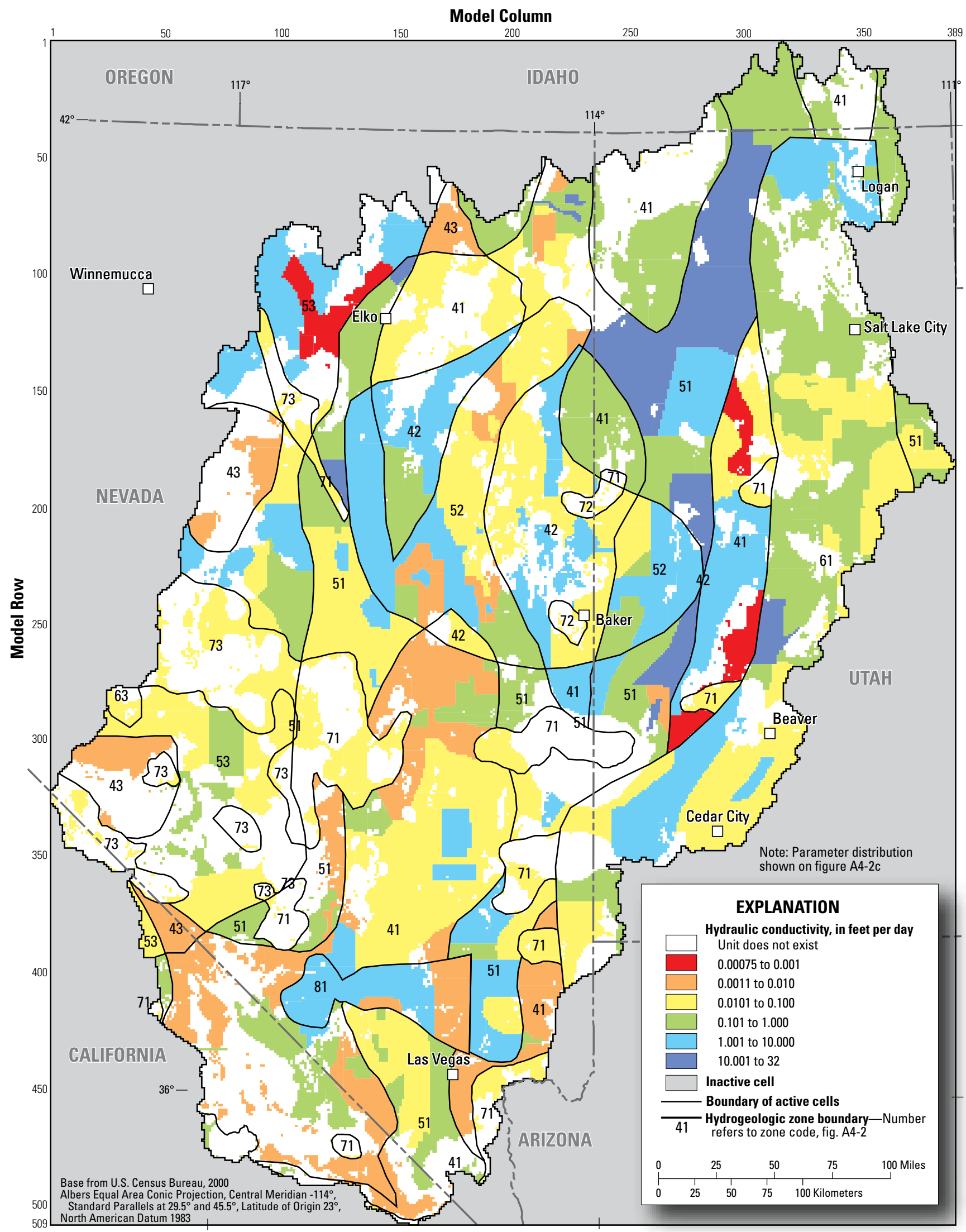

Figure 27. Distribution of hydraulic conductivity of the lower carbonate aquifer unit (LCAU) in the numerical groundwater flow model, Great Basin carbonate and alluvial aquifer system study area. 


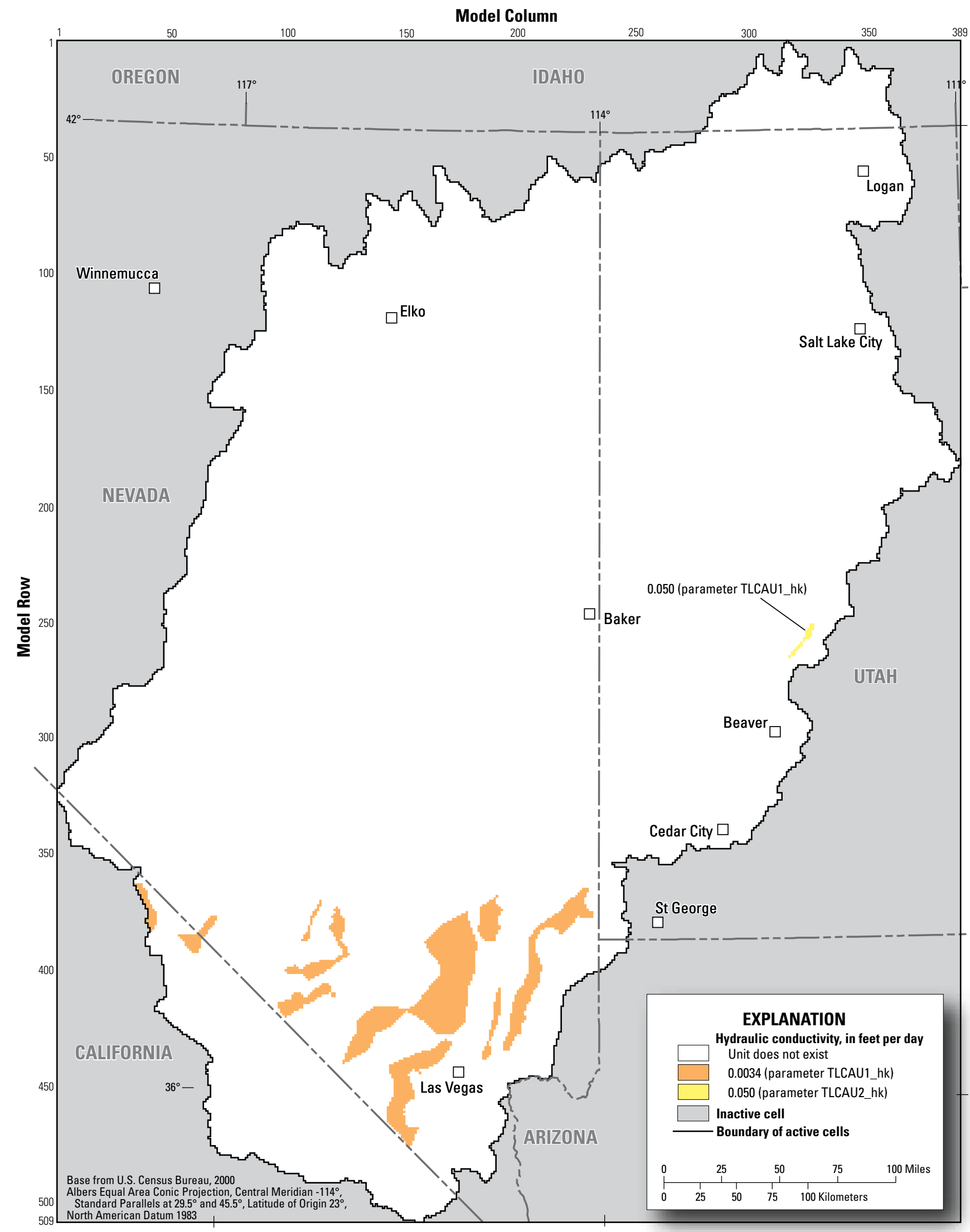

Figure 28. Distribution of hydraulic conductivity of the thrusted lower carbonate aquifer unit (TLCAU) in the numerical groundwater flow model, Great Basin carbonate and alluvial aquifer system study area. 


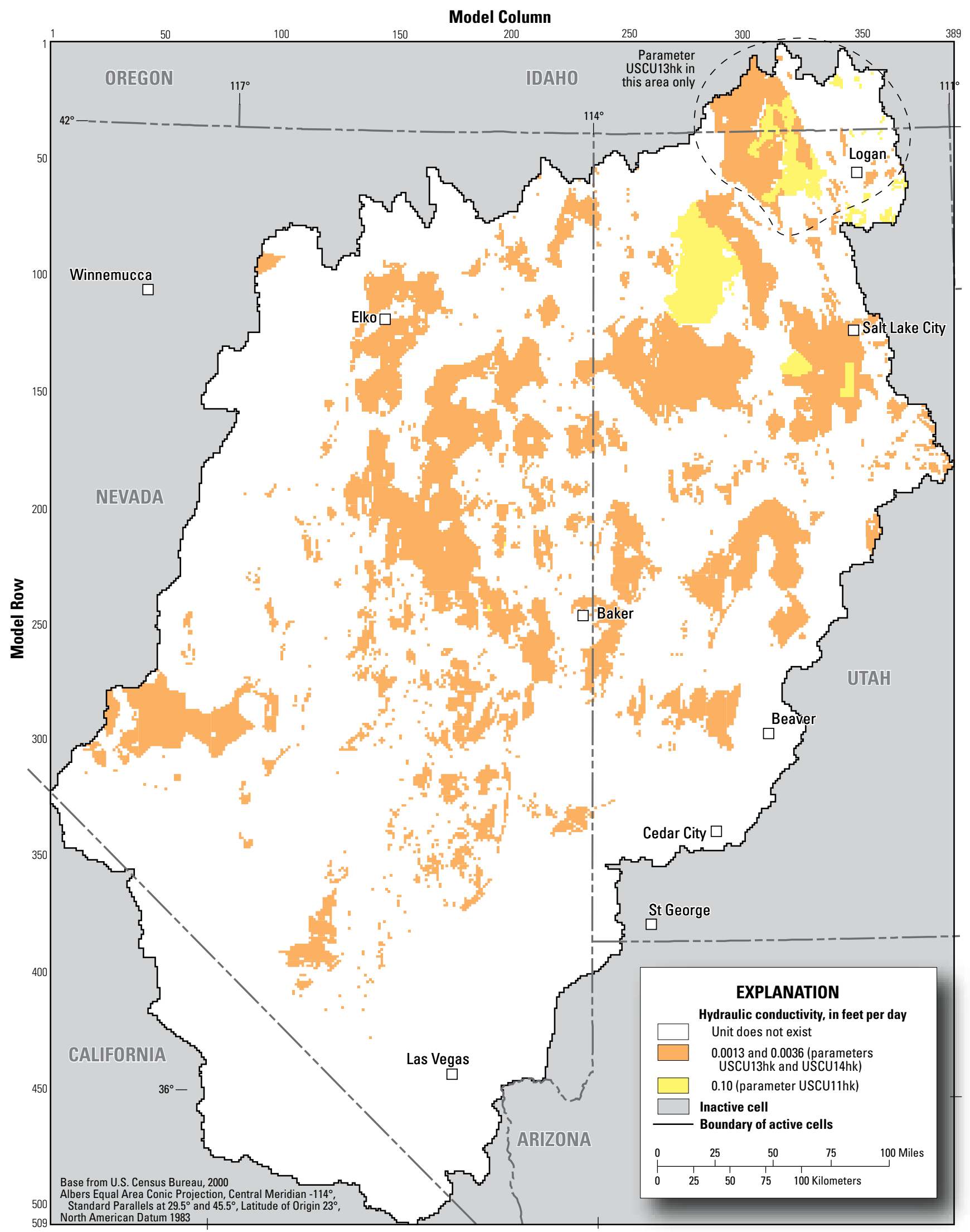

Figure 29. Distribution of hydraulic conductivity of the upper siliciclastic confining unit (USCU) in the numerical groundwater flow model, Great Basin carbonate and alluvial aquifer system study area. 


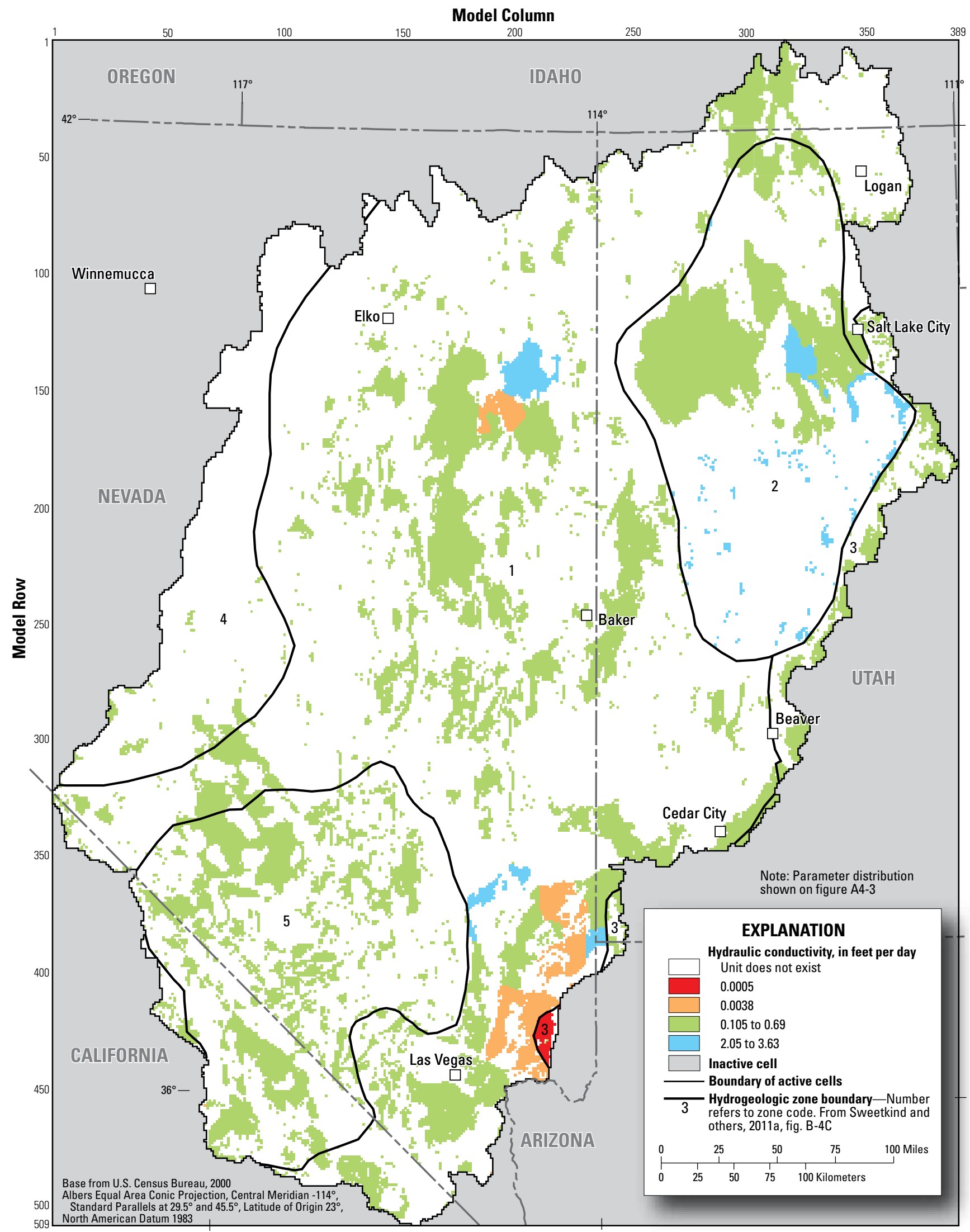

Figure 30. Distribution of hydraulic conductivity of the upper carbonate aquifer unit (UCAU) in the numerical groundwater flow model, Great Basin carbonate and alluvial aquifer system study area. 


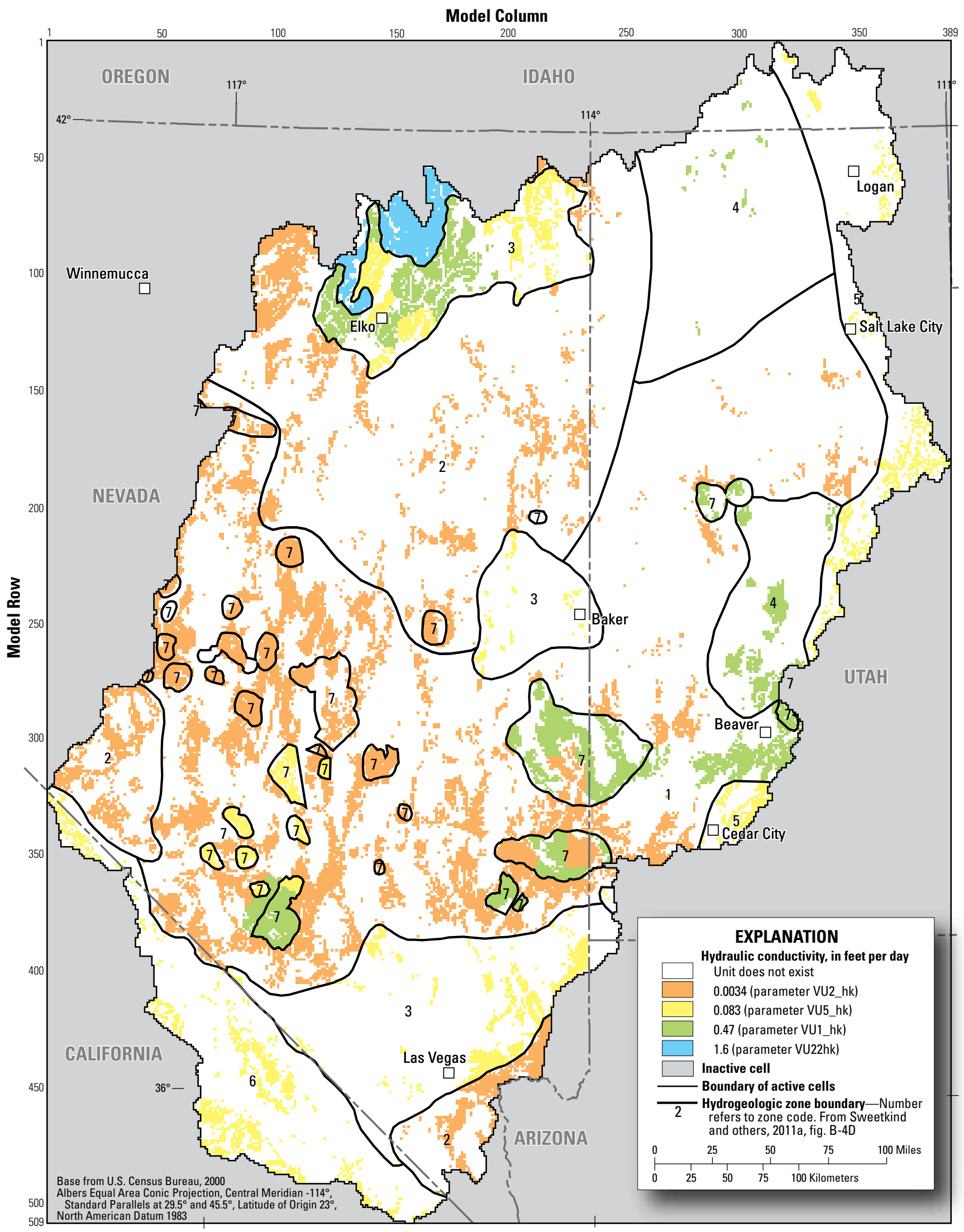

Figure 31. Distribution of hydraulic conductivity of the volcanic unit (VU) in the numerical groundwater flow model, Great Basin carbonate and alluvial aquifer system study area. 


\section{Lower Basin-Fill Aquifer Unit (LBFAU)}

The LBFAU comprises the deepest one-third of the basin fill and consists of volcanic rocks buried within the basin fill and consolidated older basin-fill rocks (Sweetkind and others, 2011a, p. 28). The simulated values provide little data about the hydraulic conductivity of this unit (fig. 21), and only four parameters with values ranging from 0.042 to $0.5 \mathrm{ft} / \mathrm{d}$ are defined specifically for this HGU (fig. A4-4; table A4-3). Some zones in the LBFAU are assigned to parameters also representing the hydraulic conductivity of the VU (table A4-3). A small area of the LBFAU in Virgin River Valley (HA 222) is assigned a parameter representing the UCAU (table A4-3; fig. A4-4) because the geologic framework had a possible error in that area and what is represented as basin fill may be the UCAU. The parameter assignments described above create eight values of hydraulic conductivity in the LBFAU ranging from 0.0034 to $0.5 \mathrm{ft} / \mathrm{d}$ (fig. 32; table A4-3). The values of the parameters defined for this HGU are within the reasonable range (fig. 22). The simulated values provide enough information to constrain the estimates of the parameters to within smaller ranges than the conceptual constraints. The standard deviation calculated by UCODE_2005 is less than the observed standard deviation of 1.6 on the log values of the parameters (tables 3 and A4-3).

\section{Upper Basin-Fill Aquifer Unit (UBFAU)}

The UBFAU comprises the shallowest two-thirds of the basin fill and includes a wide variety of basin-fill sediments (Sweetkind and others, 2011a, p. 28). Most of the discharge in the study area and in the model occurs through this layer as ETg. The simulated values provide much more information about this unit than about the LBFAU (fig. 21), and 14 parameters are defined in the model (fig. A4-5; table A4-3). A small area of the UBFAU in Virgin River Valley (HA 222) is assigned a parameter representing the UCAU (table A4-3; fig. A4-5) because the geologic framework had a possible error in that area and what is represented as basin fill may be the UCAU. Using these parameters, the values of hydraulic conductivity in the UBFAU range from about 0.11 to $120 \mathrm{ft} / \mathrm{d}$ (fig. 33). The values of the parameters defined for this HGU are within the reasonable ranges (fig. 22). The simulated values provide enough information to constrain the estimates of the parameters to within smaller ranges than the conceptual constraints. The standard deviation calculated by UCODE_2005 is less than the observed standard deviation of 1.1 on the log values of the parameters (tables 3 and A4-3).

\section{Vertical Anisotropy}

Two vertical anisotropy parameters were initially defined, one for the UBFAU and one for all other HGUs. Initial sensitivity analysis indicated that the observations provide little information about these parameters (fig. 20). During calibration, however, vertical anisotropy in the UBFAU and LBFAU was sometimes important to simulate the observed discharge to evapotranspiration, and three parameters (table A4-5) are defined to allow anisotropy in basin-fill units to vary up to 990 (figs. 34 and 35). Areas of the LBFAU and a small area of the UBFAU have the same vertical anisotropy of 1.0 as defined for consolidated-rock HGUs (table A4-5; figs. 34 and 35). One small area of the VU with a known vertical gradient also used a vertical anisotropy parameter estimated for basin fill (table A4-5; fig. 34). The values of the four vertical anisotropy parameters are within reasonable ranges (fig. 22; table 6). The simulated values provide enough information to constrain the estimates of the parameters to within smaller ranges than the conceptual constraints. The standard deviation calculated by UCODE_2005 is less than the observed standard deviation of 0.5 on the log values of the parameters (tables 6 and A4-5).

\section{Drain and River Conductance}

The conductances of drain (representing ETg and springs) and river boundaries are defined as parameters in the groundwater flow model. The simulated values provide enough information about the conductance of drains representing ETg (fig. 21) to define 16 ETg parameters in the model (fig. A4-7; table A4-6). The parameters are multipliers (fig. 36) of the conductance originally defined during model construction (see "Head-dependent Flow Boundaries" section of this report). All of the parameters have values that are within or have confidence intervals that overlap the reasonable range (fig. 22; table 6). The simulated values provide enough information to constrain the estimates of 12 of the 16 parameters to within smaller ranges than the conceptual constraints. For those parameters, the standard deviation calculated by UCODE_2005 is less than the observed standard deviation of 0.15 on the log values of the parameters (tables 6 and A4-6). Prior information was used for the other four parameters (table 7) for the statistics presented in this report. The ETg parameters were assigned by individual or groups of HAs (fig. A4-7); this provides the variability needed to achieve calibration of this regional model, but should not be considered accurate at the cell-by-cell level.

The simulation with these parameter values has simulated rates of discharge to ETg ranging from 0 to about $16 \mathrm{ft} / \mathrm{yr}$ (fig. 37). With the exception of one cell in HA 285, all rates above $5 \mathrm{ft} / \mathrm{yr}$ are in 51 cells that are either simulating discharge to the Bear River in Malad-Lower Bear River Area (HA 273) or are near the constant-head boundary of Utah Lake in Utah Valley Area (HA 265). Near the constant-head boundary, the specified drain depth representing the bottom of the root zone is below the specified altitude of Utah Lake, and an infinite supply of water can be simulated to ETg. Even with these processes occurring, fewer than 2 percent of the cells with simulated ETg have rates greater than $2 \mathrm{ft} / \mathrm{yr}$.

The simulated values provide little information about the parameters defining conductance of springs and rivers (fig. 21) and only two parameters are defined (table A4-6; fig. 22). One parameter (discharge) is defined for all springs, for rivers in the Virgin River Valley (HA 222), and for the Sevier River 


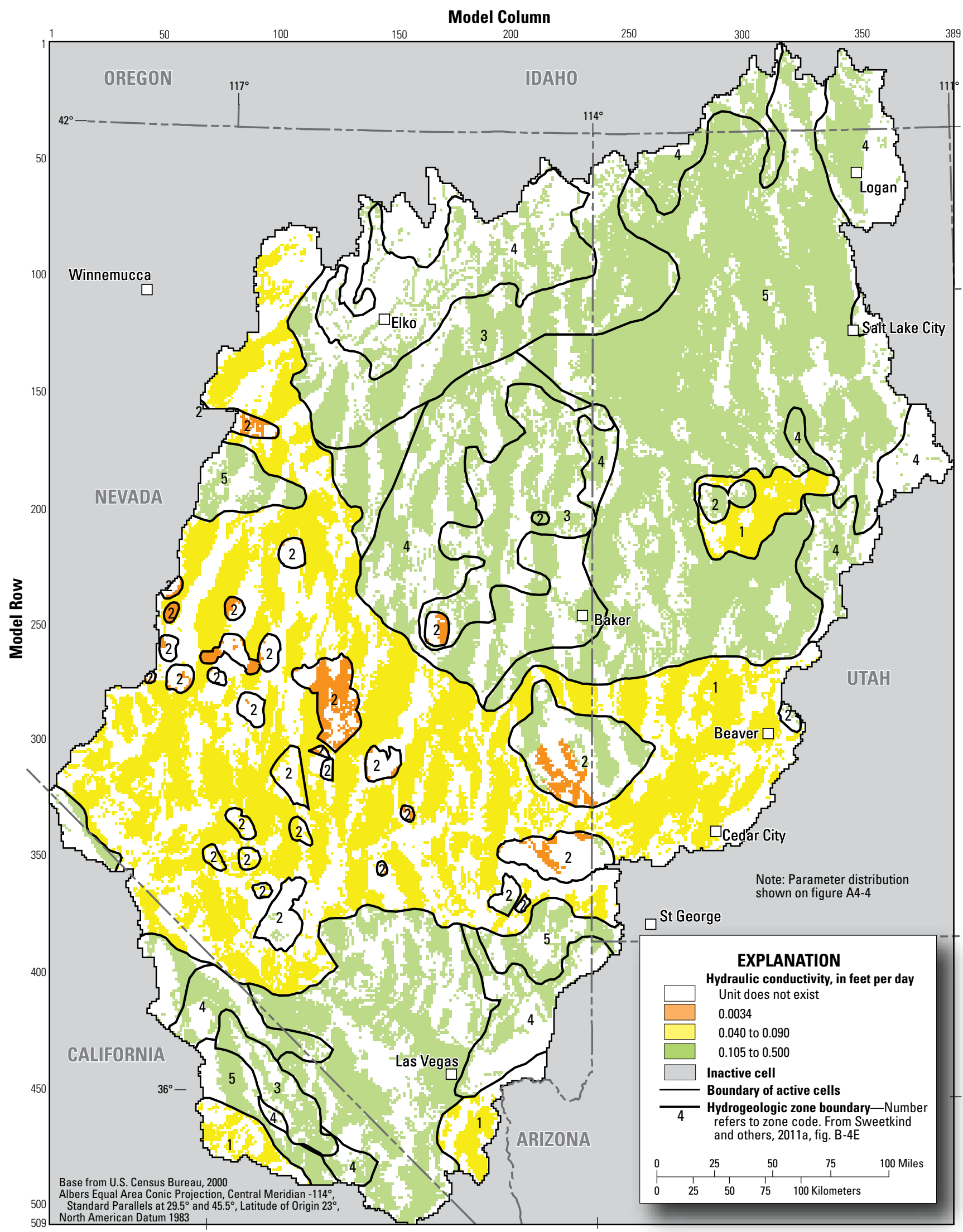

Figure 32. Distribution of hydraulic conductivity of the lower basin-fill aquifer unit (LBFAU) in the numerical groundwater flow model, Great Basin carbonate and alluvial aquifer system study area. 


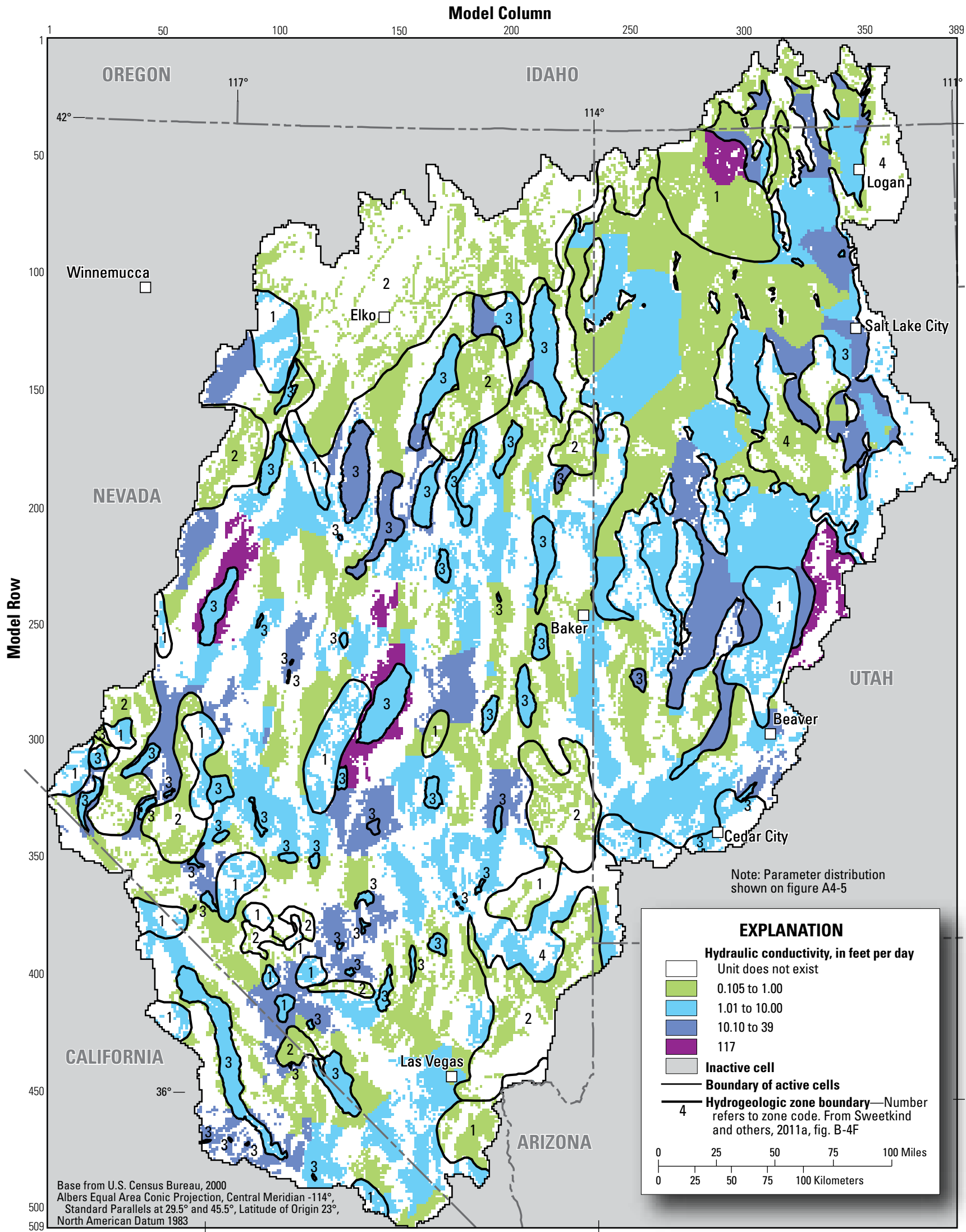

Figure 33. Distribution of hydraulic conductivity of the upper basin-fill aquifer unit (UBFAU) in the numerical groundwater flow model, Great Basin carbonate and alluvial aquifer system study area. 


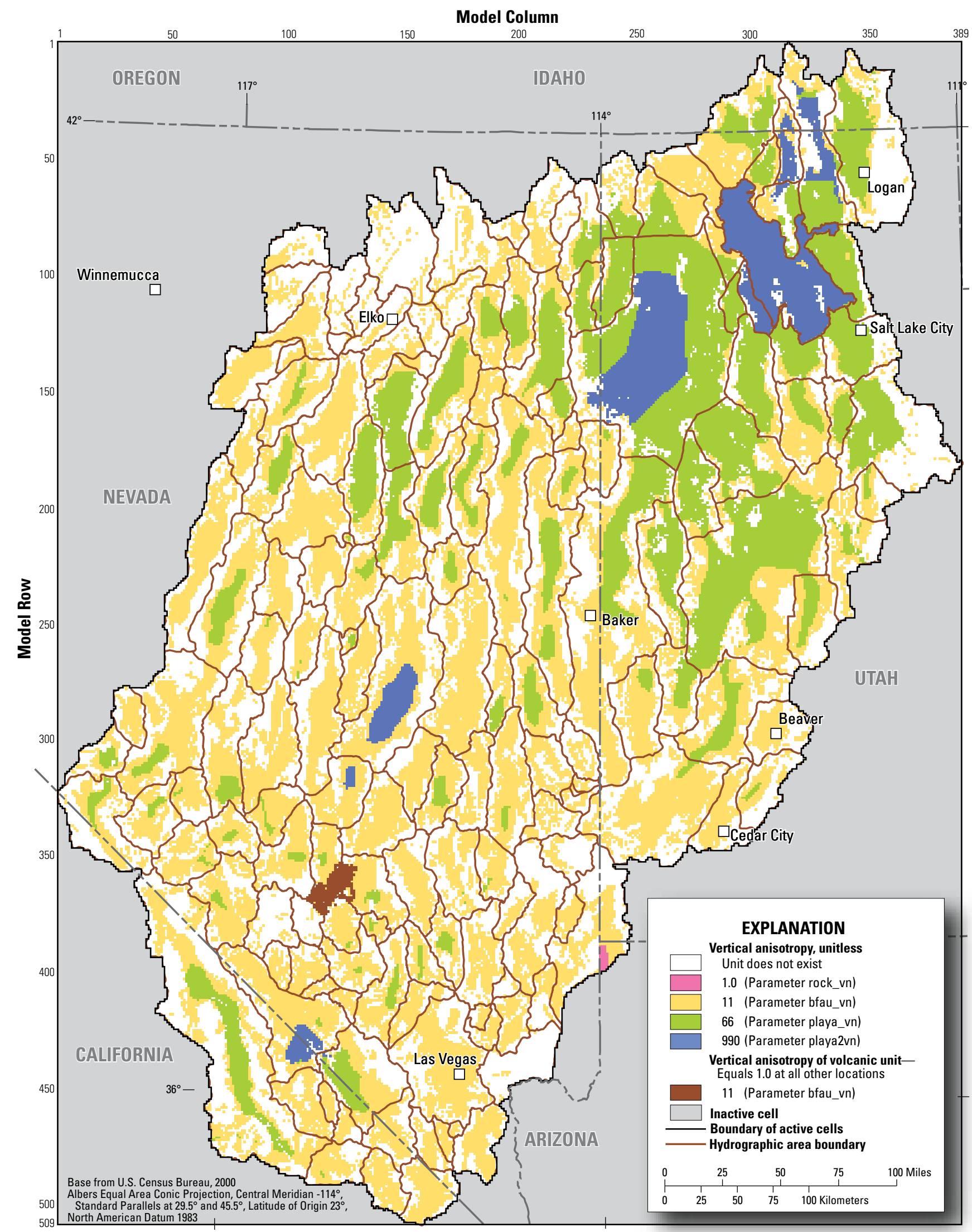

Figure 34. Distribution of vertical anisotropy of the upper basin-fill aquifer unit (UBFAU) and volcanic unit (VU) in the numerical groundwater flow model, Great Basin carbonate and alluvial aquifer system study area. 


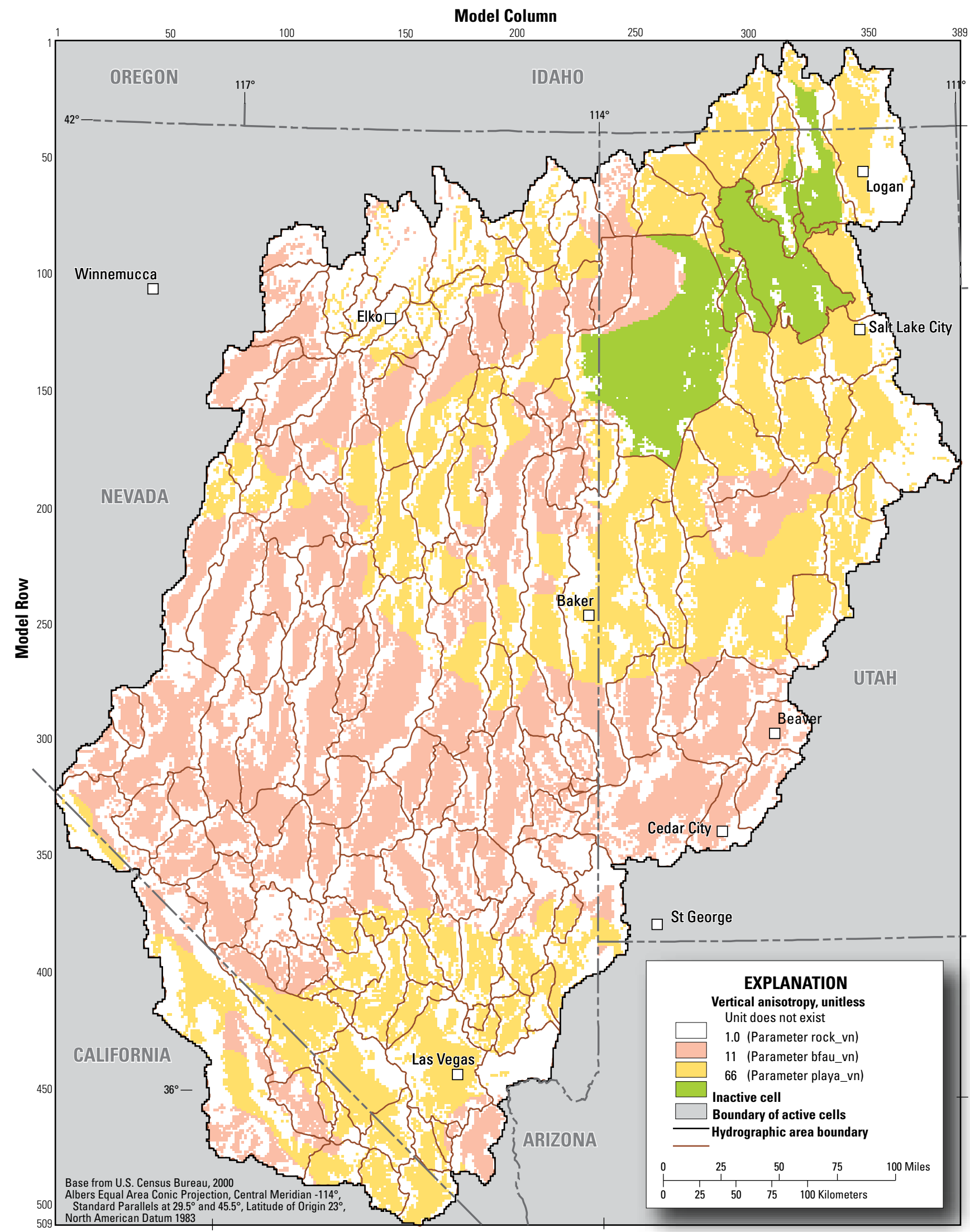

Figure 35. Distribution of vertical anisotropy of the lower basin-fill aquifer unit (LBFAU) in the numerical groundwater flow model, Great Basin carbonate and alluvial aquifer system study area. 


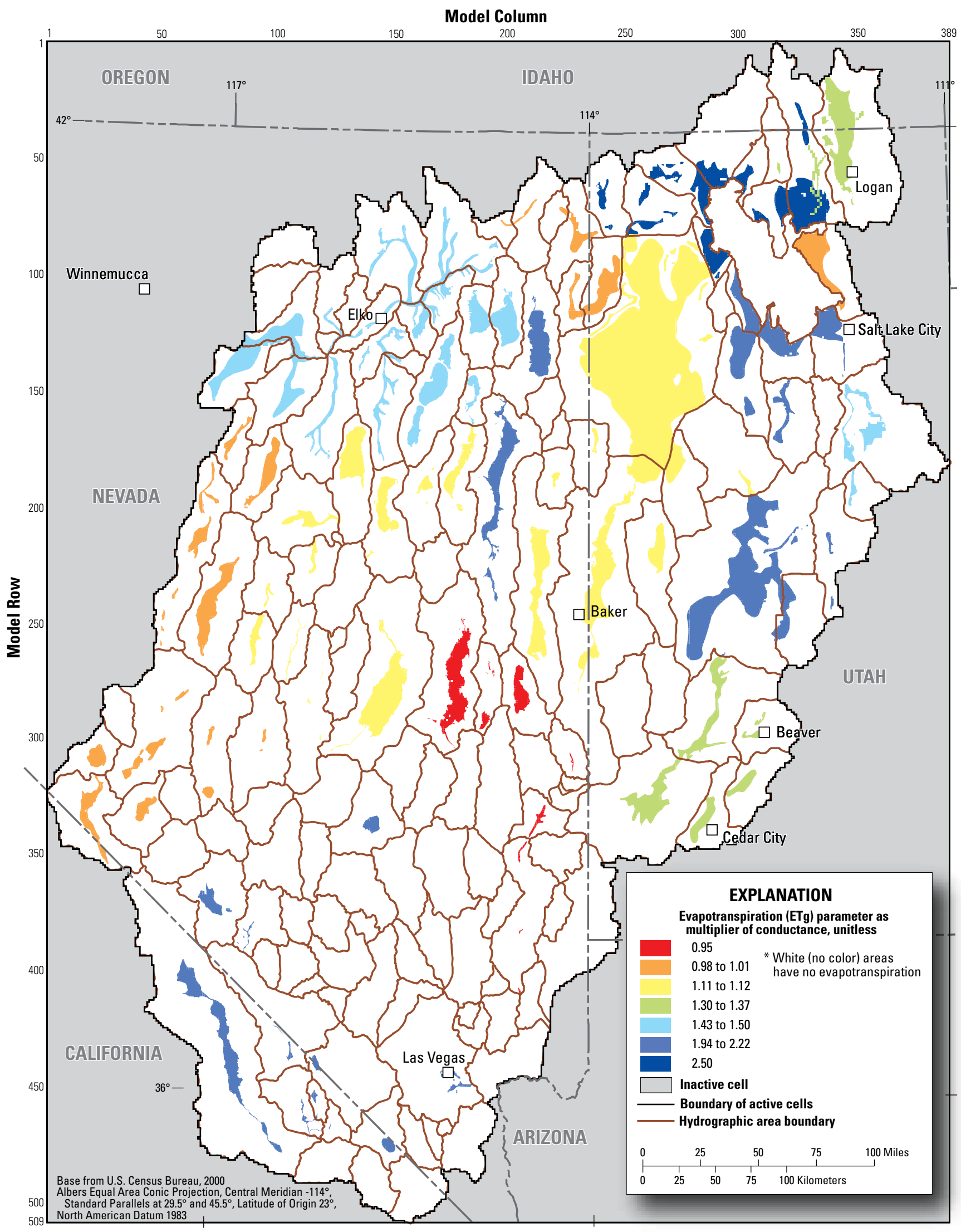

Figure 36. Distribution of parameter values for evapotranspiration in the numerical groundwater flow model, Great Basin carbonate and alluvial aquifer system study area. 


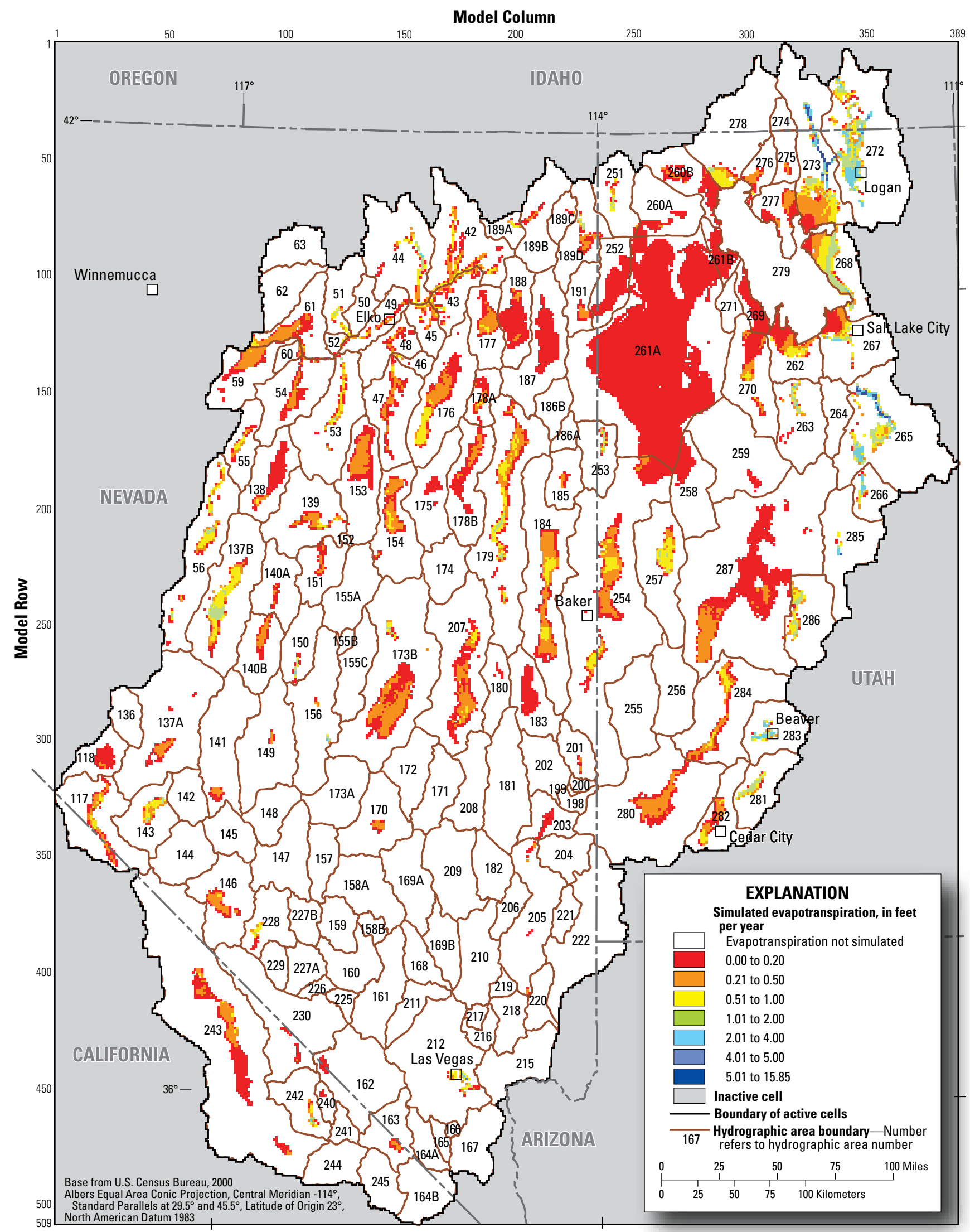

Figure 37. Distribution of simulated evapotranspiration in the numerical groundwater flow model, Great Basin carbonate and alluvial aquifer system study area. 
(HAs 285 and 287); and one parameter (river) is defined for mountain rivers and the Bear (HA 272) and Jordan (HA 267) Rivers.

The rivers in Virgin River Valley (HA 222) and the Sevier River were simulated with the smaller parameter value to cause simulated discharge of the rivers and nearby springs, or ETg, to match observed discharge more closely. Using the larger parameter value caused too much discharge to rivers and too little to springs in the northern part of Virgin River Valley (HA 222) and to ETg in Leamington Canyon (HA 285). The mountain rivers were included in the parameter with the greater value because one use of this numerical model is to test the concept of mountain rivers being connected to the groundwater system. A low riverbed conductance would limit the discharge to mountain rivers even if the simulated water level was above the riverbed altitude. The Bear and Jordan Rivers were included in the parameter with the greater value because of their width and large groundwater inflow. The two parameters are within the reasonable range (tables 6 and A4-6). The simulated values provide enough information to constrain the estimates of the parameters to within smaller ranges than the conceptual constraints. The standard deviation calculated by UCODE_2005 is less than the observed standard deviation of 1.8 on the $\log$ values of the parameters (tables 6 and A4-6).

\section{Lateral Inflow and Outflow}

The simulated values did not provide much information about these parameters (fig. 21), which are multipliers of the conceptual amounts as described in the "Model Construction" section of this report. These values were not changed from their original values of 1.0 (table A4-4).

\section{Horizontal-Flow Barriers}

Simulated values provide little information about the conductance of HFBs (fig. 21); CSS of each HFB parameter may be low because of the small value (Hill and Tiedeman, 2007, p. 43). Seven parameters are defined in the model (table A4-7; fig. 18) to cause simulated values to match observed values of water levels and discharge. Four of the seven HFB parameters were estimated using UCODE_2005 (fig. 21). The values of the other three HFB parameters were set to adequately simulate water levels or discharge without causing water levels to be above land surface on the upgradient side of the HFB. All of the parameter values are within the reasonable range (fig. 22). The simulated values provide enough information to constrain the estimates of the parameters to within smaller ranges than the conceptual constraints. The standard deviation calculated by UCODE_2005 is less than the observed standard deviation of 2.7 on the $\log$ values of the parameters (tables 6 and A4-7).

\section{Model Evaluation}

The calibrated GBCAAS model was evaluated to assess the likely accuracy of simulated results. As part of the model evaluation, the model fit to observations of water levels and discharge, comparison of simulated to conceptual water-level contours, and comparison of simulated to conceptual water budgets were evaluated. Results of this evaluation, as detailed in the following sections, indicate this model provides a reasonable representation of the regional groundwater system.

\section{Model Fit to Observations}

Model fit to observations (table 8 ) is evaluated by using both unweighted and weighted residuals (the difference between observed and simulated values). Unweighted residuals have the same dimensions as the observations and are clearly understood, but they can be misleading because observations may be measured with different accuracy. Two unweighted residuals that are of equal value may not indicate an equally satisfactory model fit. Given the large regional scale of this model, calibration attempts were concentrated to reduce unweighted residuals to $200 \mathrm{ft}$ for water levels and 30 percent of flow for discharge observations (pls. 1 and 2).

Weighted residuals are used in summary statistics (table 8) and regression. Weighted residuals are dimensionless quantities that reflect model fit in the context of the expected accuracy of the observations (Hill and Tiedeman, 2007, p. 35). A weighted residual of 2.0, for example, indicates that the unweighted residual is twice the observation error, where the error is defined as standard deviation. Weighted residuals are expected to be random and normally distributed (Hill and Tiedeman, 2007, p. 109). The correlation coefficient $\left(R^{2} N\right)$ between the weighted residuals and the normal order statistics as calculated by UCODE_2005 for this model is 0.95 . This is less than the required 0.987 (Hill and Tiedeman, 2007, table D-3), which indicates the residuals are not normally distributed. Histograms of the residuals (figs. 38A and B), however, show that the distribution has little skew. The weighted residuals for observations of water levels in wells are more normally distributed than other residuals; the $\mathrm{R}^{2} \mathrm{~N}$ for water levels in wells is 0.98 , and for discharge observations is 0.91 .

The square root of the sum of square weighted residuals (SOSWR; table 8) divided by the number of observations (Nobs) is called the standard error of the regression (Hill and Tiedeman, 2007, p. 95) and provides a measure of model fit relative to the weighting that can be compared for different types of observations. A value of 1.0 indicates a match that is, overall, consistent with the observation error evaluation used to determine the weighting (Hill and Tiedeman, 2007, p. 96). The standard error of the regression can be used to multiply the standard deviations and coefficients of variation of observations to obtain dimensional values that reflect the fit of any group of observations (Hill and Tiedeman, 2007, p. 95). 
Table 8. Summary statistics for measures of model fit in the numerical groundwater flow model, Great Basin carbonate and alluvial aquifer system study area.

[Abbreviations: SOSWR, sum of squared weighted residuals; Nobs, number of observations; Rnormal, correlation between weighted residuals and normal order statistics; —, not applicable; ET, evapotranspiration]

\begin{tabular}{|c|c|c|c|c|c|c|c|c|c|}
\hline \multirow[b]{2}{*}{ Type of observation } & \multirow[b]{2}{*}{$\begin{array}{c}\text { Number of } \\
\text { observations }\end{array}$} & \multicolumn{2}{|c|}{ Unweighted residuals } & \multicolumn{6}{|c|}{ Weighted residuals } \\
\hline & & $\begin{array}{l}\text { Average } \\
\text { residual }\end{array}$ & $\begin{array}{c}\text { Average } \\
\text { residual } \\
\text { as percent } \\
\text { of range } \\
\text { (for water } \\
\text { levels) or } \\
\text { average (for } \\
\text { discharge) }\end{array}$ & $\begin{array}{c}\text { Average } \\
\text { positive } \\
\text { weighted } \\
\text { residual }\end{array}$ & $\begin{array}{c}\text { Average } \\
\text { negative } \\
\text { weighted } \\
\text { residual }\end{array}$ & $\begin{array}{c}\text { Average } \\
\text { weighted } \\
\text { residual }\end{array}$ & SOSWR & $\begin{array}{c}\text { Standard } \\
\text { error of } \\
\text { regression, } \\
\left.\text { (SOSWR/ }^{\text {Nobs) }}\right)^{1 / 2}\end{array}$ & Rnormal \\
\hline \multicolumn{10}{|c|}{ Water levels $^{1}$} \\
\hline Water levels in wells & 1,529 & 12 & 0.1 & 3.74 & -3.65 & -0.14 & 38,896 & 5.04 & 0.98 \\
\hline River altitudes $^{2}$ & 33 & 158 & 4.2 & 5.00 & - & 5.00 & 1,519 & 6.78 & - \\
\hline Spring altitudes ${ }^{3}$ & 187 & 50 & 0.7 & 3.20 & -0.008 & 1.62 & 2,941 & 3.97 & - \\
\hline Total & 1,749 & 19 & - & 3.73 & -3.27 & 0.14 & 43,356 & 4.98 & - \\
\hline \multicolumn{10}{|c|}{ Discharge $^{4}$} \\
\hline Spring discharge & 158 & $-22,200$ & -4.1 & 1.17 & -1.62 & -0.48 & 733 & 2.15 & - \\
\hline ET discharge & 99 & $-104,720$ & -3.4 & 1.58 & -1.25 & 0.12 & 486 & 2.22 & - \\
\hline River discharge & 53 & $-30,516$ & -2.0 & 1.43 & -1.86 & -0.12 & 259 & 2.21 & - \\
\hline Constant-head discharge & 5 & $-189,738$ & -7.1 & 2.71 & -1.36 & -0.55 & 21 & 2.05 & - \\
\hline Total & 315 & $-52,194$ & - & 1.37 & -1.53 & -0.23 & 1,499 & 2.18 & 0.91 \\
\hline \multicolumn{10}{|c|}{ All observations } \\
\hline Total & 2,064 & - & - & 3.40 & -2.98 & 0.08 & 44,855 & 4.66 & 0.95 \\
\hline
\end{tabular}

${ }^{1}$ Positive water-level residual indicates simulated value is less than observed value.

${ }^{2}$ River altitudes are only included as observations if the river is not discharging enough water; therefore, simulated values are always below observed values.

${ }^{3}$ Simulated altitudes of springs cannot be very much above the observed value because the spring discharges water and reduces the head to the observed value.

${ }^{4}$ Positive discharge residual indicates simulated discharge is more than observed discharge (greater negative value).

\section{Water-Level Observations}

The fit of simulated to observed water levels is generally good. The standard error of the regression of 5.04 for water levels in wells (table 8) multiplied by the average standard deviation of observations in wells of $23.6 \mathrm{ft}$ (table 4) indicates that the model has an overall fit to water levels in wells of $119 \mathrm{ft}$, which is within the $200 \mathrm{ft}$ considered adequate for this regional model. Eighty-six percent of the simulated values of observations of water levels in wells are within $119 \mathrm{ft}$ (one standard deviation of the error) of the observation, and 50 percent of them are within $40 \mathrm{ft}$ (table A2-1). Positive and negative residuals are distributed randomly around the study area, indicating no systematic model error occurs (pl. 1). Graphs of weighted residuals and simulated values (fig. 38C) also indicate little model bias; the weighted residuals vary randomly about a value of zero.

One water-level observation (A363135ha3) in Three Lakes Valley Southern Part (HA 211, pl. 1) has a weighted residual of -25 and appears as an outlier (fig. $38 \mathrm{C}$ ). The unweighted residual is $-94 \mathrm{ft}$, which is a little larger than nearby residuals, and the variance of the observation is less than that for nearby observations. The difference in variance is caused by the methods described in Appendix 2. Because of numerous surrounding wells, this observation probably does not have undue influence on the model calibration parameters.

\section{Discharge Observations}

Calibration included matching groundwater discharge to ETg, springs, rivers, and lakes. Simulating accurate discharge was considered important in simulating the regional budget, in understanding regional sources of water to discharge areas, and in adequately simulating the complex regional aquifer system. The fit of simulated to observed discharge is good. The standard error of the regression of 2.18 for discharge observations multiplied by the weighted coefficient of variation of discharge observations of 0.12 (table 4 ) indicates a coefficient of variation of 0.26 , which is very close to the estimated error in the discharge observations of 0.25 to 0.30 . Ninety percent of the simulated discharges are within 30 percent of the observed values, and 95 percent are within 50 percent of the observed values (tables 9 and A3-1). Positive and negative residuals are evenly distributed throughout the study area (pl. 2), and graphs of weighted residuals and simulated values (figs. $38 D$ and $E$ ) indicate little model bias; most of the weighted residuals vary randomly about a value of zero. The apparent bias toward more model error with less discharge is an artifact of using the same coefficient of variation to determine variance and weight of all ETg and river observations and of many spring observations. A smaller discharge has a smaller variance, a higher weight, and possibly a higher weighted residual under this method of weighting. 

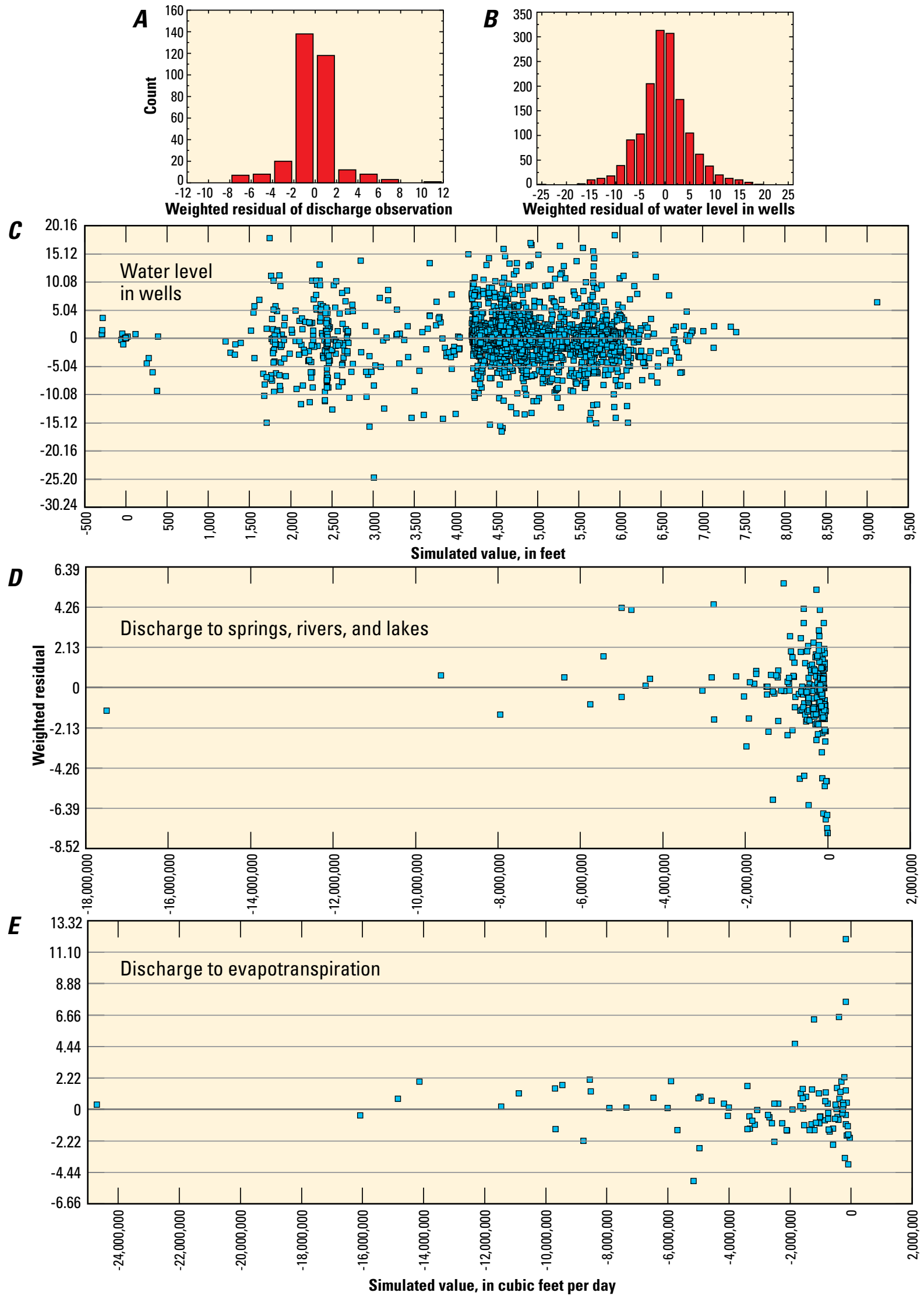

Figure 38. Weighted residuals in the numerical groundwater flow model, Great Basin carbonate and alluvial aquifer system study area. $A$, Histogram of weighted residuals of discharge; $B$, Histogram of weighted residuals of water levels in wells; $C$, Weighted residuals of water levels in wells and simulated values; $D$, Weighted residuals of discharge to springs, rivers, and lakes, and simulated values; and $E$, Weighted residuals of discharge to evapotranspiration and simulated values. 
Table 9. Summary of percent of discharge simulated in the numerical groundwater flow model, Great Basin carbonate and alluvial aquifer system study area.

\begin{tabular}{lccc}
\hline $\begin{array}{c}\text { Category of } \\
\text { discharge } \\
\text { observation }\end{array}$ & $\begin{array}{c}\text { Number of } \\
\text { observations }\end{array}$ & $\begin{array}{c}\text { Number within } \\
\text { 30 percent of } \\
\text { observation }\end{array}$ & $\begin{array}{c}\text { Number within } \\
\text { 50 percent of } \\
\text { observation }\end{array}$ \\
\hline Springs & 158 & 145 & 150 \\
Evapotranspiration & 99 & 86 & 92 \\
Streams & 53 & 48 & 51 \\
\hline Lakes & 5 & 3 & 5 \\
Total & $\mathbf{3 1 5}$ & $\mathbf{2 8 2}$ & $\mathbf{2 9 8}$ \\
\hline
\end{tabular}

One observation of discharge to ETg (et34panaca) in Panaca Valley (HA 203, pl. 2) has a weighted residual of 12 and appears as an outlier (fig. 38E). The weighted residual is large because of the small variance associated with the small observed discharge of $63,200 \mathrm{ft}^{3} / \mathrm{d}$. The unweighted residual of $101,700 \mathrm{ft}^{3} / \mathrm{d}(850 \mathrm{acre}-\mathrm{ft} / \mathrm{yr})$, represents about 0.02 percent of the flow in the model. Because of the small amount of flow, this observation probably does not have undue influence on the model calibration parameters.

\section{Simulated Water-Level Contours}

Comparison of simulated water-level contours in layer 1 (pl. 1) with the potentiometric surface of Heilweil and Brooks (2011, pl. 2) indicates that the GBCAAS model accurately simulates major features of the potentiometric surface. In general, areas of nearly flat and steep hydraulic gradients are appropriately located and the following important features are represented:

1. Mounds beneath many mountain ranges and the diversion of regional flow around these mounds.

2. Flow toward specified-head boundaries in Great Salt Lake (HA 279) and to ETg in Great Salt Lake Desert West Part (HA 261A).

3. Flow toward springs and ETg near the Humboldt River in the Humboldt (7) groundwater flow system.

4. Flow toward springs in the Colorado (34) groundwater flow system.

5. Flow toward springs and ETg in Railroad Valley Northern Part (HA 173B).

6. Flow toward springs and ETg in Amargosa Desert (HA 230) and Death Valley (HA 243).

7. The large area of relatively low hydraulic gradient throughout much of the Utah part of the study area, incorporating portions of the Sevier Lake (39) and Great Salt Lake Desert (37) groundwater flow systems.
8. Northward flow in Upper Reese River Valley (HA 56) and southward flow in the adjacent Northern Big Smoky Valley (HA 137B).

\section{Water Budgets}

The simulated budgets presented in this report are the budgets determined by the model using the calibrated parameters. The model was calibrated to water levels and groundwater discharge (see "Observations Used in Model Calibration" section of this report), not to water budgets. Uncertainty in the budgets is not presented explicitly; uncertainty in the parameters (fig. 22), however, provides an approximation of the uncertainty in the water budgets. For example, the uncertainty in recharge parameters (table A4-4) provides one measure of the uncertainty in the budgets, but uncertainty in other parameters also affects the uncertainty of the simulated budgets.

The conceptual and simulated water budgets for the study area and for the 17 groundwater flow systems in the study area (Masbruch and others, 2011) are listed in table 10. Total simulated recharge in the study area is within 10 percent of the conceptual amount; total simulated discharge is the same as conceptual discharge. Within each groundwater flow system, simulated recharge is within 30 percent of conceptual recharge with the exception of the Goshute Valley (35) groundwater flow system. Within each groundwater flow system, simulated groundwater discharge is within 20 percent of the conceptual discharge (table 10).

In the conceptual budget (table 10), four groundwater flow systems have budget imbalances of greater than 30 percent (discharge is either less than 70 percent or more than 130 percent of recharge). In the numerical model, these flow systems all have 25 percent or greater imbalances. The imbalances indicate that Monte Cristo Valley (23), Grass Valley (25), and Diamond Valley (27) groundwater flow systems are sources of water to other groundwater flow systems in both the conceptual model and the numerical model, and that Railroad Valley (30) groundwater flow system gains water from other groundwater flow systems in both the conceptual and numerical models (fig. 39). All other groundwater flow systems have less imbalance in both the conceptual and numerical models and are within the 30-percent range of possible error (Masbruch and others, 2011, p. 88). These similarities in groundwater budgets indicate that the numerical model is representing regional flow at a level comparable to the conceptual accuracy.

The simulated recharge in the Goshute Valley (35) groundwater flow system of 146 percent of the conceptual recharge is more probable than the conceptual recharge for the following reasons:

1. The previous definition of groundwater flow systems (Harrill and others, 1988) assumed that all recharge in the groundwater flow system exited as discharge within the flow system. The strict application of that definition required the GBCAAS conceptual budget to reduce the $\mathrm{BCM}$ recharge by using a multiplier of 0.59 (Masbruch and others, 2011, fig. D-8). 
Table 10. Comparison of conceptual and simulated recharge and discharge for each groundwater flow system in the numerical groundwater flow model, Great Basin carbonate and alluvial aquifer system study area.

[All flows in acre-feet per year rounded to two significant figures. Abbreviations: —, no inflow or outflow simulated]

\begin{tabular}{|c|c|c|c|c|c|c|c|c|c|c|}
\hline \multirow[b]{2}{*}{ Groundwater flow system name } & \multicolumn{3}{|c|}{ Conceptual } & \multicolumn{3}{|c|}{ Simulated } & \multirow{2}{*}{$\begin{array}{l}\text { Model } \\
\text { recharge as } \\
\text { percent of } \\
\text { conceptual } \\
\text { recharge }\end{array}$} & \multirow{2}{*}{$\begin{array}{c}\text { Model } \\
\text { discharge as } \\
\text { percent of } \\
\text { conceptual } \\
\text { discharge }\end{array}$} & \multicolumn{2}{|c|}{ Simulated } \\
\hline & $\begin{array}{l}\text { Ground- } \\
\text { water } \\
\text { recharge }\end{array}$ & $\begin{array}{l}\text { Ground- } \\
\text { water } \\
\text { discharge }^{2}\end{array}$ & $\begin{array}{l}\text { Discharge } \\
\text { as percent } \\
\text { of recharge }\end{array}$ & $\begin{array}{l}\text { Ground- } \\
\text { water } \\
\text { recharge }\end{array}$ & $\begin{array}{l}\text { Ground- } \\
\text { water } \\
\text { discharge }\end{array}$ & $\begin{array}{l}\text { Discharge } \\
\text { as percent } \\
\text { of recharge }\end{array}$ & & & $\begin{array}{l}\text { Subsurface } \\
\text { inflow from } \\
\text { outside the } \\
\text { study area }\end{array}$ & $\begin{array}{c}\text { Subsurface } \\
\text { outflow to } \\
\text { outside the } \\
\text { study area }\end{array}$ \\
\hline Humboldt System (7) & 380,000 & 300,000 & 79 & 280,000 & 290,000 & 104 & 74 & 97 & 10,000 & - \\
\hline Monte Cristo Valley (23) & 1,300 & 400 & 31 & 1,400 & ${ }^{3} 0$ & 2 & 108 & 0 & - & - \\
\hline South-Central Marshes (24) & 55,000 & 63,000 & 115 & 55,000 & 58,000 & 105 & 100 & 92 & - & - \\
\hline Grass Valley (25) & 17,000 & 9,000 & 53 & 12,000 & 8,400 & 70 & 71 & 93 & - & - \\
\hline Northern Big Smoky Valley (26) & 87,000 & 69,000 & 79 & 83,000 & 83,000 & 100 & 95 & 120 & - & - \\
\hline Diamond Valley System (27) & 110,000 & 58,000 & 53 & 85,000 & 59,000 & 69 & 77 & 102 & - & - \\
\hline Death Valley System $(28)^{4}$ & 100,000 & 100,000 & 100 & 96,000 & 100,000 & 104 & 96 & 100 & - & - \\
\hline Newark Valley System (29) & 34,000 & 32,000 & 94 & 29,000 & 36,000 & 124 & 85 & 113 & - & - \\
\hline Railroad Valley System (30) & 68,000 & 98,000 & 144 & 75,000 & 94,000 & 125 & 110 & 96 & - & - \\
\hline Independence Valley System (32) & 28,000 & 29,000 & 104 & 31,000 & 34,000 & 110 & 111 & 117 & - & - \\
\hline Ruby Valley System (33) & 79,000 & 78,000 & 99 & 65,000 & 67,000 & 103 & 82 & 86 & - & - \\
\hline Colorado System (34) & 220,000 & 230,000 & 105 & 240,000 & 230,000 & 96 & 109 & 100 & - & 700 \\
\hline Goshute Valley System (35) & 130,000 & 130,000 & 100 & 190,000 & 150,000 & 79 & 146 & 115 & - & - \\
\hline Mesquite Valley (36) & 1,900 & 2,200 & 116 & 1,800 & 2,200 & 122 & 95 & 100 & - & - \\
\hline Great Salt Lake Desert System (37) & 470,000 & 440,000 & 94 & 410,000 & 430,000 & 105 & 87 & 98 & - & - \\
\hline Great Salt Lake System (38) & $2,300,000$ & $2,100,000$ & 91 & $2,100,000$ & $2,100,000$ & 100 & 91 & 100 & - & - \\
\hline Sevier Lake System (39) & 400,000 & 410,000 & 103 & 360,000 & 370,000 & 103 & 90 & 90 & - & - \\
\hline Study area total & $4,500,000$ & $4,100,000$ & 91 & $4,100,000$ & $4,100,000$ & 100 & 91 & 100 & 10,000 & 700 \\
\hline
\end{tabular}

${ }^{1}$ Masbruch and others, 2011, table D-1.

${ }^{2}$ Masbruch and others, 2011, table D-2.

${ }^{3}$ No discharge boundaries are simulated in this flow system.

${ }^{4}$ Penoyer Valley, which Harrill and others (1988) defined as a separate groundwater flow system, is included in the Death Valley System in this report.

2. Although the reduction created balance in the groundwater flow system budget, the calculated recharge in Steptoe Valley (HA 179) became 26,000 acre-ft/yr less than discharge (Masbruch, 2011a and 2011b).

3. Because of the high altitude of water levels in Steptoe Valley, groundwater flow into the valley from other areas is not possible, and recharge was increased in the model to match discharge more closely.

4. Water-level contour maps indicate that groundwater has the potential to flow from the Goshute Valley (35) groundwater flow system to the Great Salt Lake Desert (37) and Colorado (34) groundwater flow systems, and recharge could exceed discharge in the Goshute Valley (35) groundwater flow system, as it does in the numerical model (table 10).

Differences between recharge and discharge indicate subsurface flow between groundwater flow systems. Simulated subsurface flow between flow systems (table 11) and simultaneous confidence intervals (Hill and Tiedeman, 2007, p. 175) on the amount of flow were calculated for the model by using ZONEBUDGET (Harbaugh, 1990) and the predictive capabilities of UCODE_2005 (Poeter and others, 2008). Simultaneous confidence intervals are used because the flow between flow systems is not known for any boundary. Simultaneous intervals get larger as more intervals are calculated because the uncertainty of each individual subsurface flow amount is affected by the uncertainty of all other subsurface flow amounts. The occurrence of simulated flow between groundwater flow systems (fig. 39; table 11) indicates that simulated flow directions do not match the previous definition of flow systems (Harrill and others, 1988). The large number of flow system boundaries having subsurface flows indicates that these previously defined systems do not meet a generally accepted definition of a groundwater flow system as "a three dimensional body of earth material saturated with moving groundwater that extends from areas of recharge to areas of discharge" (Alley and others, 1999). Subsurface flow across the boundaries of these previously defined flow systems is consistent with the conceptual model (Masbruch and others, 2011), the RASA numerical flow model (Prudic and others, 1995), and the DVRFS numerical flow model (Faunt and others, 2004). 


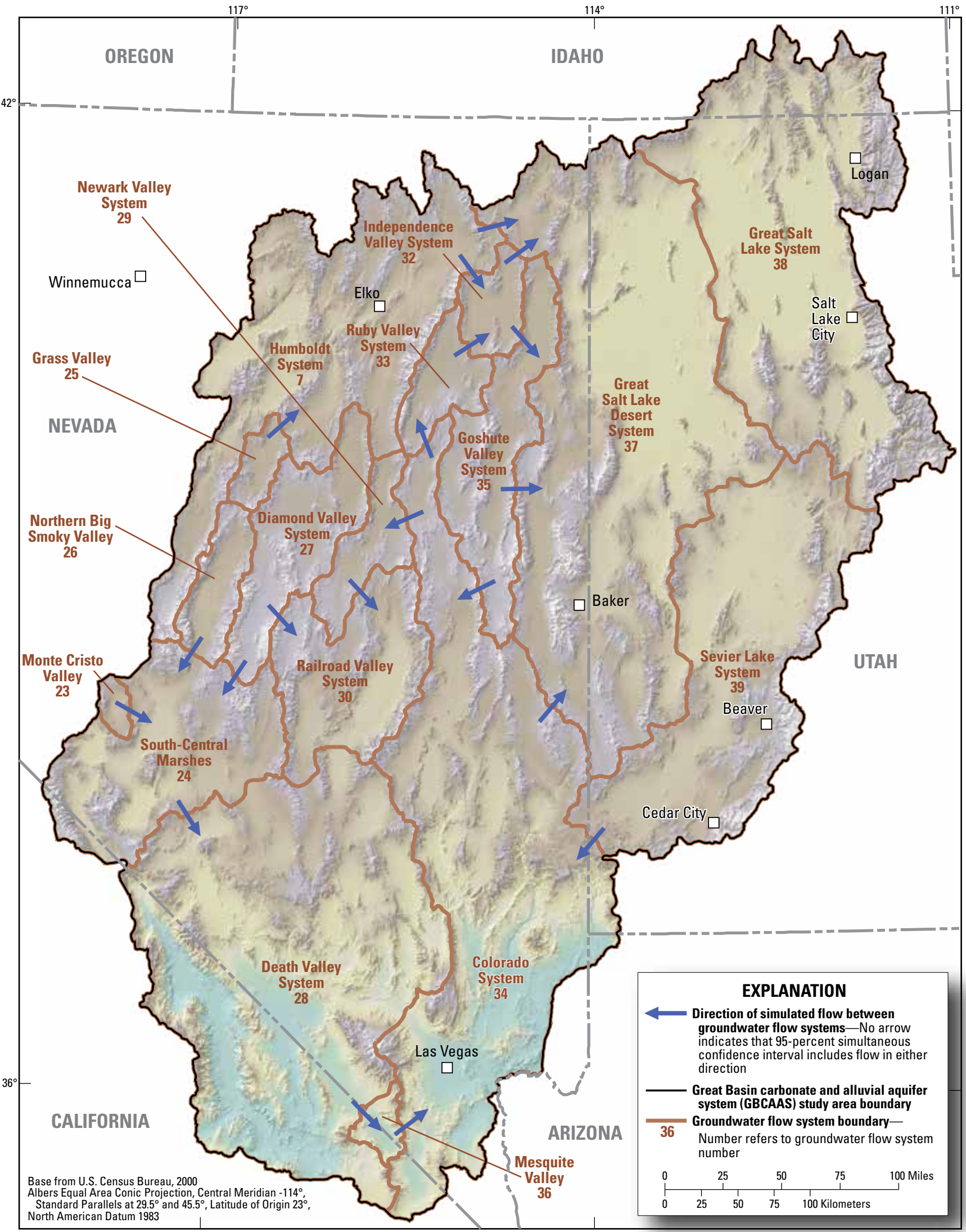

Figure 39. Direction of simulated subsurface flow between groundwater flow systems in the numerical flow model, Great Basin carbonate and alluvial aquifer system study area. 
Table 11. Model-predicted flow between groundwater flow systems in the numerical groundwater flow model, Great Basin carbonate and alluvial aquifer system study area.

[All flows in acre-feet per year, rounded to two significant figures. Negative value indicates flow is in opposite direction as listed. Lower limit and upper limit: Simultaneous 95-percent confidence intervals of the predictions calculated by UCODE_2005 (Poeter and others, 2008)]

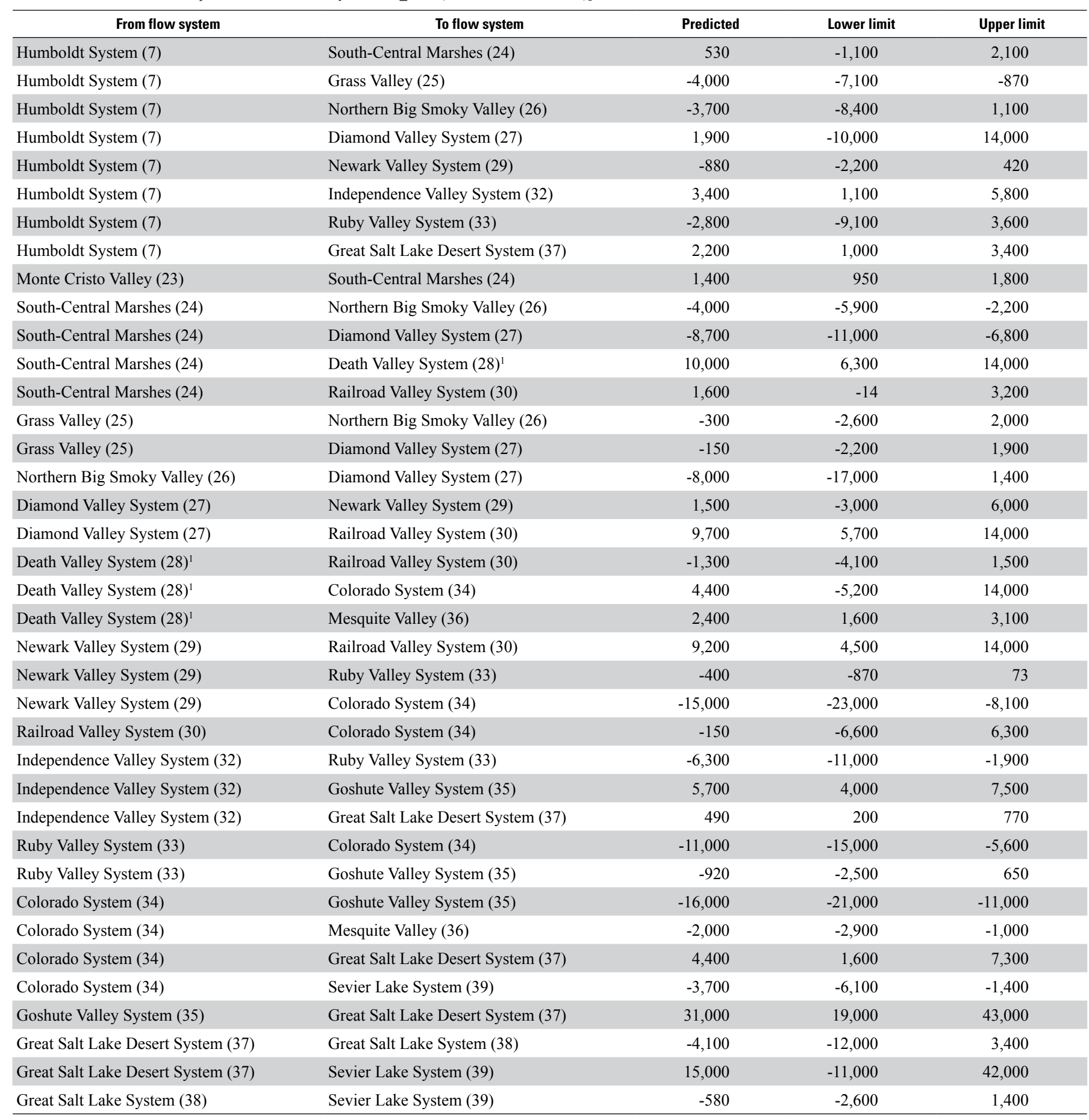

${ }^{1}$ Penoyer Valley, which Harrill and others (1988) defined as a separate groundwater flow system, is included in the Death Valley System in this report.

Comparisons of conceptual and simulated water budgets for each HA are listed in table A3-2, predicted amount of flow between HAs and simultaneous confidence intervals are listed in table A3-3, and flow direction between selected HAs is shown on fig. A3-1. The emphasis of the study and the model was regional flow; the model may provide insight and information at the HA level, but should not be the only basis for waterresource management at this scale. This report does not include a discussion of the simulated water budgets for each HA. 


\section{Model Results}

The purposes of the model are to test whether the conceptual groundwater budget and flow directions can be simulated using reasonable model parameter values while providing an appropriate match to observed water levels and discharges, and to provide a model that can be used to assess water availability and changes in water availability at a regional scale. The GBCAAS model corroborates the conceptual model presented in Heilweil and Brooks (2011) of an interconnected groundwater system between consolidated rock and basin fill and of recharge areas in the mountains connected to the basins and to the regional flow system. The concept of the mountains and basins forming a continuous groundwater system provides more detailed contours (pl. 1) and flow paths (which are perpendicular to contours) than previous studies focusing on groundwater in the carbonates (Prudic and others, 1995; Harrill and Prudic, 1998; Welch and others, 2007). The incorporation of BCM recharge and of mountain springs and streams as model observations creates higher recharge mounds under many mountain ranges and highlights that the regional flow paths in many cases go around, not through (or under), mountain ranges. One example of this is flow from Steptoe Valley (HA 179) to the east, where the flow occurs to the north and south of the mountains separating the valleys (pl. 1). The mounding and possible diversion of flow paths are not as apparent in areas with less recharge (fig. 24) such as the mountain ranges northeast of Death Valley (HA 243), in the lower part of the Colorado River model region, and in the southwestern Utah portion of the model (pl. 1).

In addition to these indications of model adequacy, the model can be used to gain insights into the groundwater system that were not included in deciding the accuracy of the calibration. These include simulated transmissivity, vertical movement and amount of deep flow, and simulated regions that have little flow between them. The model results can also be used to examine how the evolving conceptualization and numerical simulation of groundwater flow throughout the GBCAAS study area compares to previous regional models.

Because it represents an acceptable simulation of regional flow, the GBCAAS model can be used for prediction simulations within the interior of the model because the boundaries are distant from many areas of interest; this has not been previously available for much of the study area at this level of discretization. Such predictions were beyond the scope of this study.

\section{Transmissivity}

Total transmissivity of the simulated thickness controls horizontal flow, which often is more important than vertical flow at the regional scale (Haitjema, 2003). The program HUFPrint (Banta and Provost, 2008) was used to calculate the hydraulic conductivity of each model layer. This was multiplied by the thickness of the layer to determine the transmissivity of each layer, which were summed to determine total transmissivity (fig. 40).
Because model parameters describing horizontal hydraulic conductivity were not constrained during calibration, the simulated transmissivity distribution provides independent information that can be compared to known geologic features. The simulated transmissivity is compared to the hydrogeologic zones (Sweetkind and others, 2011a) and geologic controls affecting groundwater flow (Sweetkind and others, 2011b) in the following paragraphs. Areas of high transmissivity that cannot be explained by the current knowledge of geologic factors are also described. These areas may be indicative of errors in the hydrogeologic framework, errors in observation data, errors in the estimate of recharge, or other model construction errors. They warrant further investigation in more detailed studies or models including those areas.

Some of the areas of low or high transmissivity are related to specific hydrogeologic zones within HGUs. Most areas in zone 3 of NCCU (fig. A4-1), which are intrusive igneous rocks, have transmissivities of less than $10,000 \mathrm{ft}^{2} / \mathrm{d}$. Examples (fig. 40) are the igneous intrusions on the west and north sides of Snake Valley (HA 254); on the north edge of Sevier Desert (HA 287); in the northern parts of Dry Lake Valley (HA 181), Patterson Valley (HA 202), and Spring Valley (HA 201); in Fish Lake Valley (HA 117); and at the northern end of Death Valley (HA 243). The area of zone 81 of the LCAU (fig. A4-2), which is a zone of enhanced hydraulic conductivity, typically has transmissivities greater than $10,000 \mathrm{ft}^{2} / \mathrm{d}$ (fig. 40). This zone extends from the eastern part of Amargosa Desert (HA 230), east through Rock Valley (HA 226) and Mercury Valley (HA 225), to east of Three Lakes Valley Southern Part (HA 211).

Some areas of high transmissivity are related to large thicknesses of the most permeable HGUs (UBFAU, UCAU, and LCAU) as described by Sweetkind and others (2011b, p. 57). These include the following three areas with transmissivity generally greater than $10,000 \mathrm{ft}^{2} / \mathrm{d}$ : (1) the eastern part of Nevada that includes Diamond Valley (HA 153), Newark Valley (HA 154), and Ruby Valley (HA 176); (2) the southern part of Nevada that includes Sarcobatus Flat (HA 146), Frenchman Flat (HA 160), Penoyer Valley (HA 170), Railroad Valley Southern Part (HA 173A), and Amargosa Desert (HA 230); and (3) the southwestern part of Utah that includes Beryl-Enterprise Area (HA 280), Milford Area (HA 284), and Wah Wah Valley (HA 256). This last area is near an area including Snake Valley (HA 254), Pine Valley (HA 255), Tule Valley (HA 257), and Fish Springs Flat (HA 258) that fits the conceptualization of Dettinger and Schaefer (1996) of regional flow through thick sections of carbonate rock that has been extended only slightly (Sweetkind and others, 2011b, p. 60). Fish Springs Flat (HA 258) has simulated transmissivities exceeding 200,000 $\mathrm{ft}^{2} / \mathrm{d}$.

Sweetkind and others $(2011 \mathrm{~b}, \mathrm{p} .58)$ provide examples of how juxtaposition of thick, low-permeability siliciclastic-rock strata against higher permeability carbonate-rock aquifers create hydraulic flow barriers on the east and west sides of Northern Big Smoky Valley (HA 137B) and along the northwest edge of Ruby Valley (HA 176). These areas are represented in 


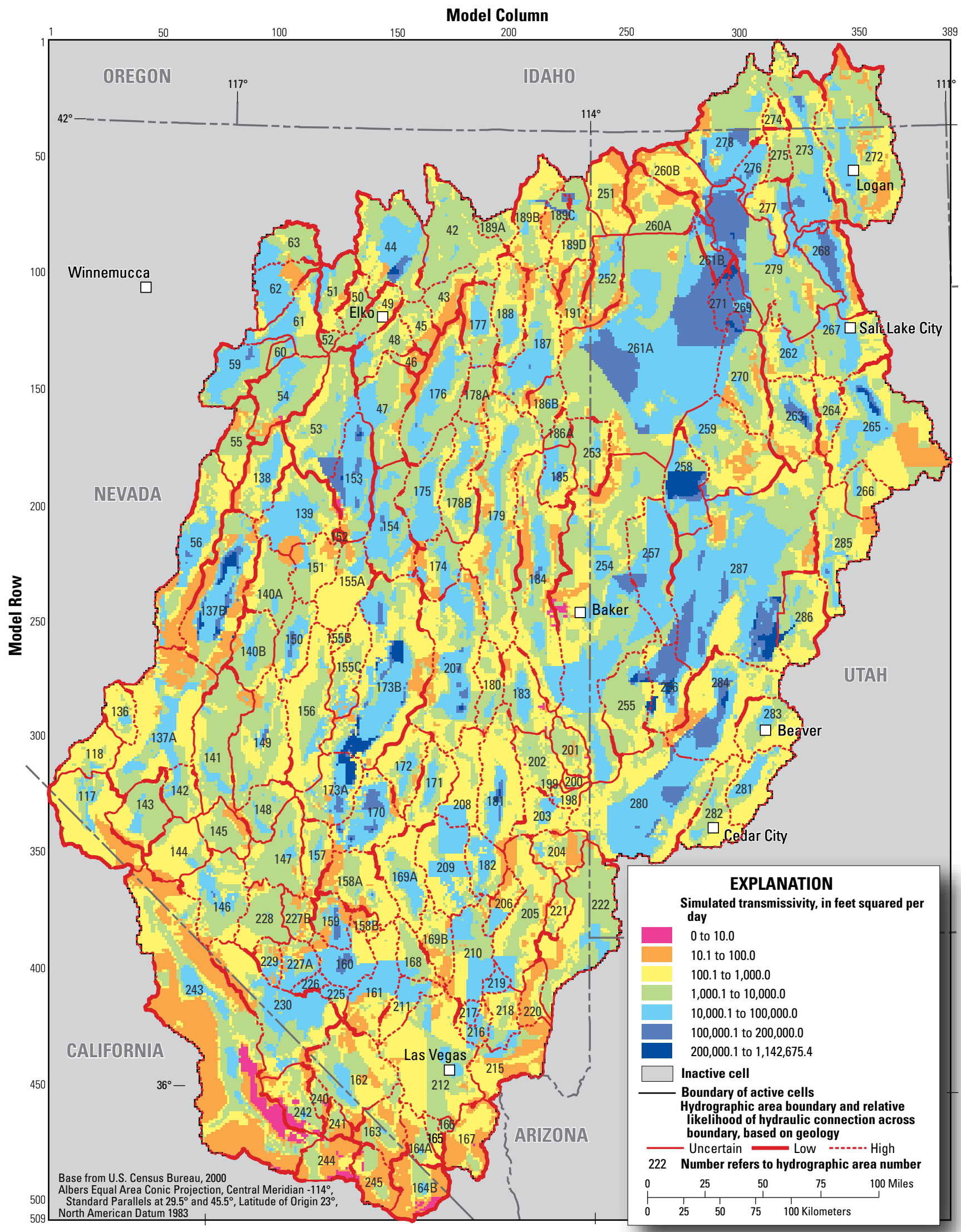

Figure 40. Simulated transmissivity in the numerical groundwater flow model, Great Basin carbonate and alluvial aquifer system study area. 
the model by transmissivities of less than $1,000 \mathrm{ft}^{2} / \mathrm{d}$ (fig. 40). Juxtaposition also causes the low likelihood of hydraulic connection between Amargosa Desert (HA 230) and Death Valley (HA 243; Sweetkind and others, 2011b, p. 59), which is simulated in the model by transmissivities of less than $100 \mathrm{ft}^{2} / \mathrm{d}$ along much of the boundary. Regional thrust faults that bring low-permeability siliciclastic-rock strata to shallow depths (Sweetkind and others, 2011b, p. 58) result in reduced total transmissivity at the boundary between Kawich Valley (HA 157) and Emigrant Valley-Groom Lake Valley (HA 158A), and on the western side of Lower Moapa Valley (HA 220). This is simulated in the model by transmissivities of less than $100 \mathrm{ft}^{2} / \mathrm{d}$ in these areas (fig. 40). Areas with greatly extended terrains may have reduced permeability where permeable consolidated carbonate rocks have been thinned or removed, such as the area south of Muddy River Springs Area (HA 219; Sweetkind and others, 2011b, p. 60). This area has simulated transmissivities of less than $10,000 \mathrm{ft}^{2} / \mathrm{d}$.

Some areas of high transmissivity are not explained by known geologic factors. One of these is the large area of high transmissivity in and northeast of Great Salt Lake Desert-West Part (HA 261A). Sweetkind and others (2011b, p. 57) proposed that the flat gradient (pl. 1) in that area is caused by the large area of ETg, flat land-surface topography, homogenous aquifer material, and little recharge. In the model, however, the water-level observations could not be matched adequately without high transmissivity in the area (fig. 40). The high transmissivity is mostly simulated by high horizontal conductivity in the LCAU (fig. 27) and UBFAU (fig. 33) HGUs. Other areas with high transmissivity that were not discussed by Sweetkind and others (2011a and 2011b) are Northern Big Smoky Valley (HA 137B) and Railroad Valley Northern Part (HA 173B).

\section{Vertical Groundwater Movement and Deep Flow}

Simulating eight model layers and including water-level observations in multiple layers allowed for adequate simulation of vertical gradients. Limited data throughout the study area indicate that gradients are downward in recharge areas and upward in discharge areas, which is simulated in the model (fig. 41). One area of particular interest (Faunt and others, 2004, p. 333) is the upward gradient near Yucca Mountain; the model simulates an upward gradient in that area (HA 227A).

Results from the model show that much of the flow in the groundwater system occurs in deeper layers, even though about 86 percent of the discharge occurs in layer 1. Over 95 percent of the recharge moves down from layer 1, about 65 percent of the recharge moves as deep as layer 6 , and about 25 percent moves to layer 8 , which, on average, is about 8,000 $\mathrm{ft}$ below the top of layer 1 . Only 4 percent of the discharge occurs in layer 8, 4 percent in layer 7, and 2 percent in layer 6 , but water is circulating to these deeper layers and then moving up to discharge areas in higher model layers.

\section{Simulated Groundwater Flow Regions}

One of the fundamental results of the GBCAAS model is that considerable flow (table 11) occurs between areas that previously had been defined as separate groundwater flow systems (Harrill and others, 1988). This simulated flow indicates that there are fewer groundwater flow systems having potentially longer flow paths than presented by Harrill and others (1988). For example, Grass Valley (25) groundwater flow system contributes flow to Humboldt (7) groundwater flow system (fig. 39; table 11), and some flow recharging in Diamond Valley (27) and Goshute Valley (35) groundwater flow systems discharges near the Humboldt River. This implies that the area contributing flow to springs and ETg near the Humboldt River is larger than conceptually estimated.

Differences between simulated and conceptual (Harrill and others, 1988) groundwater flow systems were also apparent in the RASA numerical model (Prudic and others, 1995) and DVRFS conceptual and numerical models (Belcher, 2004), but have not been widely recognized outside of these reports. Prudic and others (1995) proposed five flow regions, and Belcher (2004) proposed flow from the north into the Death Valley (28) groundwater flow system and a different location of the boundary between the Death Valley (28) groundwater flow system and the Colorado (34) groundwater flow system.

The GBCAAS model was used to delineate simulated groundwater flow regions and subregions that connect recharge areas to discharge areas. For consistency with previous terminology and to prevent confusion with the 17 previously defined groundwater flow systems, model-simulated flow boundaries are referred to as GBCAAS model regions in this report. The simulated groundwater flow regions and subregions were defined by backward particle tracking from all discharge locations using MODPATH (Pollock, 1994). Boundaries were further refined using arrows as a graphical representation (FRV; C. Justin Meyers, U.S. Geological Survey, written commun., January 2013) of the cell-by-cell flow budgets determined by MODFLOW-2005 (Harbaugh, 2005). These arrows enabled visual determination of which region each model cell should be in to minimize the flow between regions. Using MODPATH and FRV, the model area was divided into six regions; four of those regions are composed of two subregions each, one of the regions is composed of three subregions, and one region has no subregions (fig. 42; table 12). This is a significant reduction from the 17 groundwater flow systems originally proposed by Harrill and others (1988). It is similar to the five deep-flow regions determined by the RASA numerical simulation with the addition of the Great Salt Lake region incorporating areas not included in the RASA simulation. 


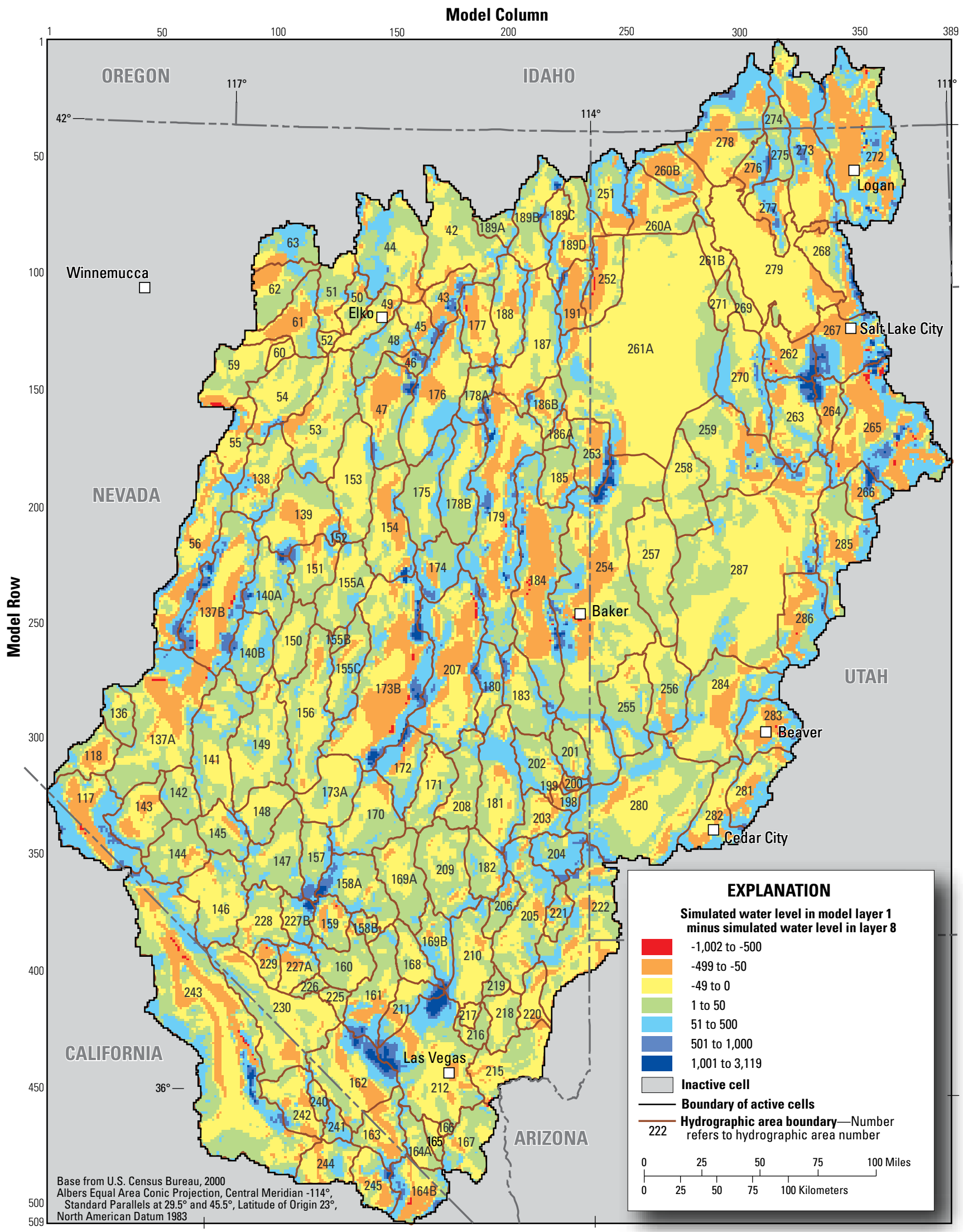

Figure 41. Simulated vertical gradient between model layers 1 and 8 in the numerical groundwater flow model, Great Basin carbonate and alluvial aquifer system study area. 


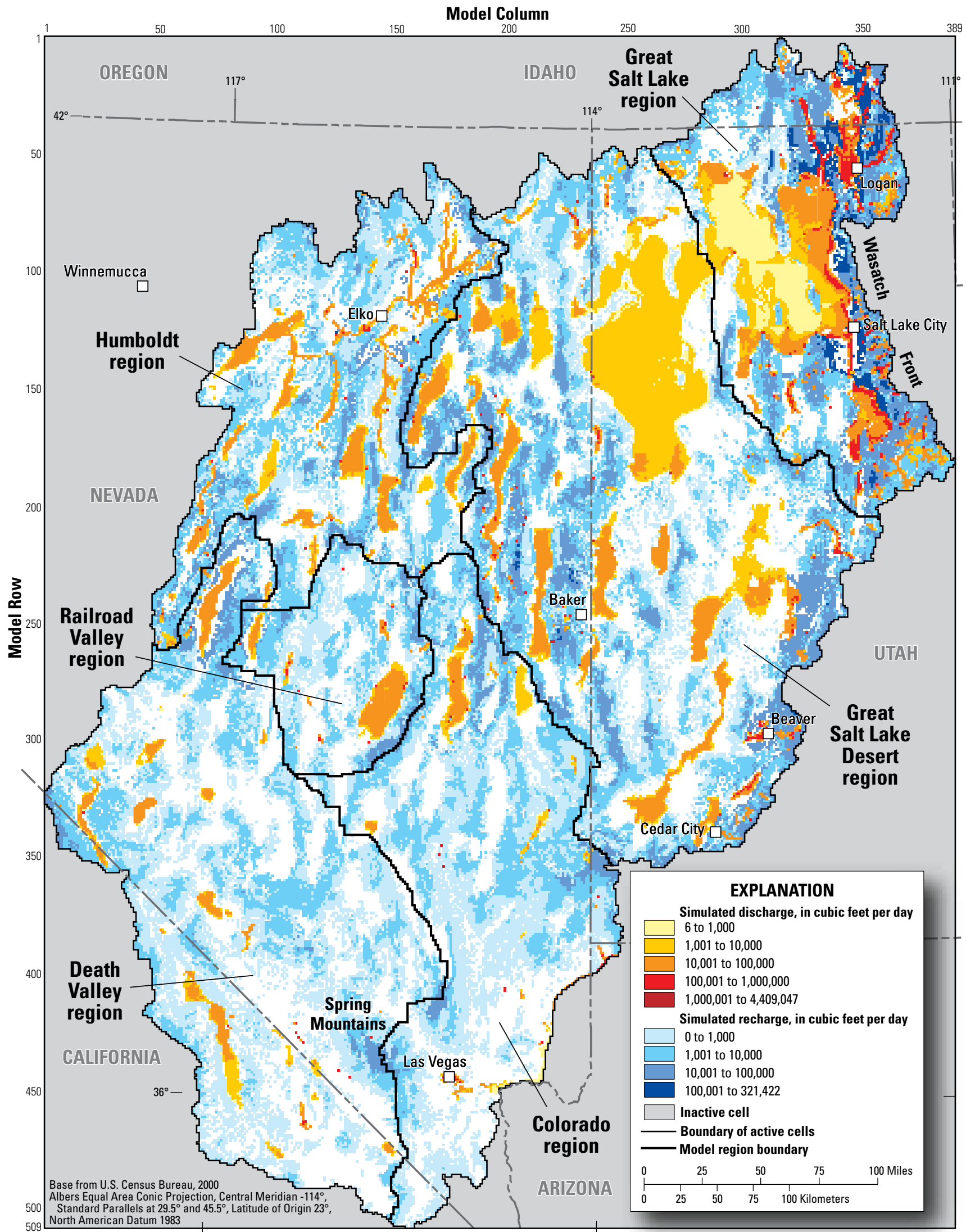

Figure 42. Model regions, simulated recharge, and simulated discharge in the numerical groundwater flow model, Great Basin carbonate and alluvial aquifer system study area. 
Table 12. Groundwater budgets for the simulated groundwater regions and subregions in the numerical groundwater flow model, Great Basin carbonate and alluvial aquifer system study area.

[All flows in acre-feet per year rounded to two significant figures. Abbreviations: —, not applicable]

\begin{tabular}{|c|c|c|c|c|c|c|c|c|c|c|c|}
\hline Subregion name & $\begin{array}{l}\text { Area, in } \\
\text { acres }\end{array}$ & Recharge & $\begin{array}{c}\text { Inflow } \\
\text { from } \\
\text { outside } \\
\text { of model } \\
\text { area }\end{array}$ & $\begin{array}{l}\text { Net inflow } \\
\text { from other } \\
\text { subregions }\end{array}$ & $\begin{array}{c}\text { Net inflow } \\
\text { from other } \\
\text { regions }\end{array}$ & Total inflow & Discharge & $\begin{array}{l}\text { Outflow } \\
\text { from the } \\
\text { study area }\end{array}$ & $\begin{array}{l}\text { Net } \\
\text { outflow to } \\
\text { other sub- } \\
\text { regions }\end{array}$ & $\begin{array}{c}\text { Net } \\
\text { outflow } \\
\text { to other } \\
\text { regions }\end{array}$ & $\begin{array}{c}\text { Total } \\
\text { outflow }\end{array}$ \\
\hline \multicolumn{12}{|c|}{ Great Salt Lake region } \\
\hline Great Salt Lake subregion & $7,635,200$ & $1,500,000$ & 0 & 12 & 0 & $1,500,000$ & $1,500,000$ & 0 & 0 & ${ }^{1} 240$ & $1,500,000$ \\
\hline Cache subregion & $1,186,560$ & 640,000 & 0 & 0 & - & 640,000 & 640,000 & 0 & 12 & - & 640,000 \\
\hline Total & $8,820,000$ & $2,100,000$ & $\mathbf{0}$ & - & $\mathbf{0}$ & $2,100,000$ & $2,100,000$ & $\mathbf{0}$ & - & 240 & $2,100,000$ \\
\hline \multicolumn{12}{|c|}{ Great Salt Lake Desert region } \\
\hline Great Salt Lake Desert subregion & $20,716,160$ & 930,000 & 0 & 410 & 2370 & 930,000 & 930,000 & 0 & 0 & ${ }^{3} 150$ & 930,000 \\
\hline Ruby subregion & $1,543,680$ & 100,000 & - & 0 & 0 & 100,000 & 100,000 & - & 410 & ${ }^{4} 75$ & 100,000 \\
\hline Total & $22,300,000$ & $1,000,000$ & $\mathbf{0}$ & - & 300 & $1,000,000$ & $1,000,000$ & $\mathbf{0}$ & - & 150 & $1,000,000$ \\
\hline \multicolumn{12}{|c|}{ Humboldt region } \\
\hline Humboldt subregion & $8,358,400$ & 330,000 & 10,000 & 11 & ${ }^{5} 820$ & 340,000 & 340,000 & 0 & 0 & ${ }^{6} 420$ & 340,000 \\
\hline Reese River subregion & $1,373,440$ & 62,000 & 0 & 0 & 0 & 62,000 & 62,000 & 0 & 11 & ${ }^{7} 120$ & 62,000 \\
\hline Total & $9,730,000$ & 390,000 & 10,000 & - & 700 & 400,000 & 400,000 & $\mathbf{0}$ & - & 420 & 400,000 \\
\hline \multicolumn{12}{|c|}{ Railroad Valley region } \\
\hline Total & $3,550,720$ & 110,000 & - & - & ${ }^{8280}$ & 110,000 & 110,000 & - & - & 9560 & 110,000 \\
\hline \multicolumn{12}{|c|}{ Colorado region } \\
\hline Muddy River Springs subregion & $9,621,120$ & 190,000 & 0 & 27 & ${ }^{10} 530$ & 190,000 & 190,000 & 1,000 & 0 & ${ }^{11} 270$ & 190,000 \\
\hline Virgin subregion & $1,385,600$ & 44,000 & 0 & 0 & ${ }^{12} 400$ & 44,000 & 45,000 & 0 & 27 & 0 & 45,000 \\
\hline Total & $11,000,000$ & 230,000 & $\mathbf{0}$ & - & 680 & 230,000 & 240,000 & 1,000 & - & 20 & 240,000 \\
\hline \multicolumn{12}{|c|}{ Death Valley region } \\
\hline Northern Big Smoky subregion & 952,320 & 85,000 & - & ${ }^{13} 110$ & 0 & 85,000 & 85,000 & - & 0 & ${ }^{14} 640$ & 86,000 \\
\hline Big Smoky subregion & $3,155,840$ & 57,000 & 0 & ${ }^{15} 270$ & ${ }^{16} 10$ & 57,000 & 57,000 & 0 & ${ }^{17} 110$ & ${ }^{18} 110$ & 57,000 \\
\hline Death Valley subregion & $11,272,320$ & 100,000 & 0 & 0 & ${ }^{19} 190$ & 100,000 & 100,000 & - & ${ }^{20} 270$ & 0 & 100,000 \\
\hline Total & $15,400,000$ & 240,000 & $\mathbf{0}$ & - & $\mathbf{0}$ & 240,000 & 240,000 & $\mathbf{0}$ & - & 580 & 240,000 \\
\hline \multicolumn{12}{|c|}{ Model area } \\
\hline Total model area & $71,000,000$ & $4,100,000$ & 10,000 & - & - & $4,100,000$ & $4,100,000$ & 1,000 & - & - & $4,100,000$ \\
\hline
\end{tabular}

${ }^{1}$ To Great Salt Lake Desert region.

${ }^{2} 240$ acre-feet per year from Great Salt Lake region, 130 acre-feet per year from Humboldt region.

${ }^{3}$ To Colorado region.

${ }^{4}$ To Humboldt region.

${ }^{5} 420$ acre-feet per year from Death Valley region, 400 acre-feet per year from Railroad Valley region.

${ }^{6} 360$ acre-feet per year to Colorado region, 60 acre-feet per year to Great Salt Lake Desert region.

${ }^{7}$ To Death Valley region.

${ }^{8}$ From Death Valley region.

${ }^{9} 400$ acre-feet per year to Humboldt region, 170 acre-feet per year to Colorado region.

${ }^{10} 360$ acre-feet per year from Humboldt region, 170 acre-feet per year from Railroad Valley region.

${ }^{11} 250$ acre-feet per year to Great Salt Lake Desert region, 20 acre-feet per year to Death Valley region.

${ }^{12}$ From Great Salt Lake Desert region.

${ }^{13}$ From Big Smoky subregion.

${ }^{14} 310$ acre-feet per year to Humboldt region, 340 acre-feet per year to Railroad Valley region.

${ }^{15}$ From Death Valley subregion.

${ }^{16}$ From Humboldt region.

${ }^{17}$ To Northern Big Smoky subregion.

${ }^{18}$ To Railroad Valley region.

${ }^{19} 170$ acre-feet per year from Railroad Valley region, 20 acre-feet per year from Colorado region.

${ }^{20}$ To Big Smoky subregion. 
The general criteria for delineating the subregions were as follows:

1. Net flow across the boundary between any two subregions is less than about $500 \mathrm{acre}-\mathrm{ft} / \mathrm{yr}$.

2. Particles discharging in one subregion could not originate in another subregion except near the boundary at a recharge area. Less than about 10 percent of the particles discharging in a subregion could originate in any one adjacent subregion.

Particle tracking indicates flow to some discharge areas, such as ETg in Great Salt Lake Desert (HA 261A) and springs in Fish Springs Flat (HA 258), ETg in Death Valley (HA 243) and springs in Amargosa Desert (HA 230), and springs in Muddy River Springs Area (HA 219), initially enters the aquifer as recharge several basins away. Delineating the recharge areas contributing to these discharge areas created the largest subregions (Great Salt Lake Desert subregion, Death Valley subregion, and Muddy River Springs subregion, respectively; table 12). In some areas, such as Steptoe Valley (HA 179), Spring Valley (HA 184), and Snake Valley (HA 254), it is not possible to delineate individual recharge areas for all discharge within each HA using this method. Even though particles do not flow from one valley to the next, recharge in model cells near a boundary between two HAs contributes to both HAs. In this report, those areas are combined into the Great Salt Lake Desert subregion; models with smaller grid-cell size may provide a more distinct delineation.

The delineation of flow regions is meant to provide some indication that under the stresses and hydraulic properties simulated in the GBCAAS model, all discharge in each subregion is supplied by recharge in the same subregion. The delineation also highlights that groundwater divides may not follow surface-water divides, and that divides may occur in areas that have a high likelihood of hydraulic connection based on geology (pl. 1). The simulated regional boundaries should not be considered no-flow boundaries; groundwater development, which is not simulated in this model, could induce flow across the boundaries. The effects of groundwater development, such as capture of natural discharge and water-level declines, are independent of these boundaries (Reilly, 2001, p. 12-14;

Table 13. Simulated discharge for each model region in the numerical groundwater flow model, Great Basin carbonate and alluvial aquifer system study area.

[All flows in acre-feet per year rounded to two significant figures]

\begin{tabular}{lccrrr}
\hline \multirow{2}{*}{ Model region name } & \multicolumn{5}{c}{ Simulated discharge } \\
\cline { 2 - 6 } & Evapotranspiration & Springs & \multicolumn{1}{c}{ Rivers } & \multicolumn{1}{c}{ Lakes } & Total \\
\hline Great Salt Lake & $1,100,000$ & 290,000 & 610,000 & 100,000 & $2,100,000$ \\
\hline Great Salt Lake Desert & 770,000 & 170,000 & 88,000 & 1,200 & $1,000,000$ \\
\hline Humboldt & 350,000 & 40,000 & 12,000 & 0 & 400,000 \\
Railroad Valley & 76,000 & 32,000 & 1,000 & 0 & 110,000 \\
Colorado & 70,000 & 120,000 & 42,000 & 1,600 & 230,000 \\
Death Valley & 200,000 & 34,000 & 3,800 & 0 & 240,000 \\
Total discharge & $\mathbf{2 , 6 0 0 , 0 0 0}$ & $\mathbf{6 9 0 , 0 0 0}$ & $\mathbf{7 6 0 , 0 0 0}$ & $\mathbf{1 0 0 , 0 0 0}$ & $\mathbf{4 , 1 0 0 , 0 0 0}$ \\
\hline
\end{tabular}

Barlow and Leake, 2012, p. 40-41). Different recharge distributions could change these boundaries. This delineation may not be unique; it is possible that other delineations could meet the two guidelines discussed above.

An analysis of the regions indicates that the regions have differences in the simulated budgets, the areal distribution of recharge and discharge, and the percent of discharge to ETg, springs, rivers, and lakes (table 13). Some regions have relatively evenly distributed recharge and discharge, but some have recharge concentrated in one portion of the region and discharge concentrated in other portions (fig. 42). Most have ETg as the largest component of discharge, but the percent of discharge to either springs or rivers is different (table 13).

The Great Salt Lake region has the largest simulated groundwater budget and accounts for about 50 percent of the model budget (table 12); the region contains only 11 percent of the model area. About 53 percent of the discharge in this region is to ETg, 29 percent to rivers, 14 percent to springs, and 5 percent to lakes (tables 13 and A3-1). This region has both a larger percent and larger amount of discharge to rivers than any other region. Recharge occurs on all the mountain ranges, but is largest along the Wasatch Front (fig. 42). Discharge is distributed throughout the region. This region has only 11 percent of the flow occurring in layer 8 , the smallest percent of any region, which may be caused by the relatively equal distribution of recharge and discharge. This region includes areas outside the RASA model and part of the RASA model Bonneville region (fig. 43; Prudic and others, 1995, fig. 33). It closely incorporates the Great Salt Lake (38) groundwater flow system of Harrill and others (1988).

The Great Salt Lake Desert region has the second largest simulated groundwater budget and accounts for about 25 percent of the model budget; the region contains 31 percent of the model area (table 12). About 77 percent of the discharge in the region is to ETg, 17 percent to springs, and 9 percent to rivers (tables 13 and A3-1). Recharge is concentrated in the southeast and west portions of the region (fig. 42). Discharge is distributed throughout the region as ETg in most of the basins; a few of the basins have little or no discharge. This region has 36 percent of the flow occurring in layer 8 . The region is similar to the RASA model Bonneville region (fig. 43; Prudic and others, 1995, fig. 33) and mostly incorporates five groundwater flow systems of Harrill and others (1988). The exception is the omission of Butte Valley Southern Part (HA 178B) from the GBCAAS model region.

The Humboldt region has a simulated budget of about 10 percent of the model budget and contains about 14 percent of the model area (table 12). About 87 percent of the discharge in this region is to ETg, 10 percent to springs, and 3 percent to rivers (tables 13 and A3-1). Recharge is distributed on the mountain ranges 


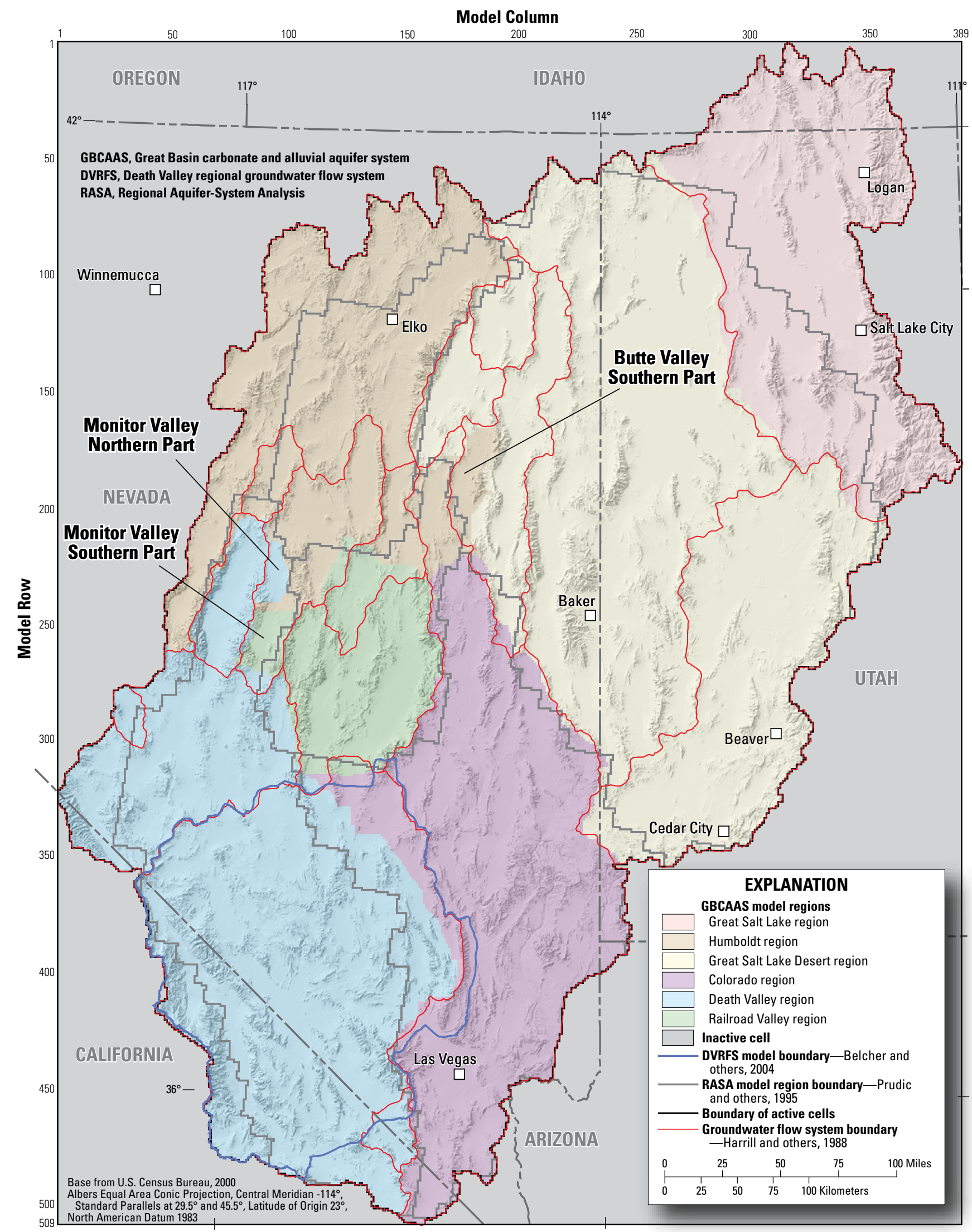

Figure 43. Model regions in the numerical groundwater flow model and previous boundaries in the Great Basin carbonate and alluvial aquifer system study area. 
throughout the region (fig. 42), but is largest along the east edge and in the southwest portion of the region. Discharge is distributed throughout the region. This region has 28 percent of the flow occurring in layer 8 . This second smallest percent among the regions is probably caused by the relatively equal distribution of recharge and discharge. The GBCAAS region is larger than the RASA model region (fig. 43) and incorporates all of two and parts of four groundwater flow systems of Harrill and others (1988).

The Railroad Valley region has a simulated budget of about 3 percent of the model budget and contains about 5 percent of the model area (table 12). About 69 percent of the discharge is to ETg, 28 percent to springs, and 1 percent to one mountain stream (tables 13 and A3-1). Recharge is largest on the west, north, and east edges of the region (fig. 42). Discharge is concentrated in a few basins, mostly in Railroad Valley Northern Part (HA 173B). This region has 34 percent of the flow occurring in layer 8 . The region is smaller than the RASA model region (fig. 43) and incorporates parts of four groundwater flow systems of Harrill and others (1988).

The Colorado region has a simulated budget of about 6 percent of the model budget and contains about 15 percent of the model area (table 12). About 53 percent of the discharge is to springs, 30 percent to ETg, 18 percent to rivers (including springs to the Virgin River near Littlefield, Arizona), and less than 1 percent to Lake Mead (tables 13 and A3-1). This region has a higher percent of discharge to springs than any other region, and is the only region in which discharge to ETg is not the largest component of discharge. Recharge is concentrated in the northern part of the region, with the exception of recharge in high altitude areas in the southwest and southeast (fig. 42). Discharge is also concentrated in the northern part of the region, but some large springs discharge in the southern part of the region. This region has 70 percent of the flow occurring in layer 8 , which is the highest of all the regions. This large percent of deep flow is probably caused by the unequal areal distribution of recharge and discharge and the concentrated discharge at springs. The region is similar to the RASA model region, but does not extend as far west (fig. 43). It is also similar to the Colorado (34) groundwater flow system of Harrill and others (1988), but does not extend as far north. This region includes some area simulated by the DVRFS model (Faunt and others, 2004), but the divide between the GBCAAS Colorado and Death Valley model regions is similar to the divide simulated in the DVRFS model (Faunt and others, 2004, fig. F-49).

The Death Valley region has a simulated budget of about 6 percent of the model budget and contains about 22 percent of the model area (table 12). About 85 percent of the discharge is to ETg, 14 percent to springs, and about 1 percent to two mountain streams (tables 13 and A3-1). Recharge is concentrated in the north, the northwest, and in the Spring Mountains on the east edge of the region (fig. 42). Discharge is concentrated in the northern and western parts of the region. This region has 50 percent of the flow occurring in layer 8 , the second highest percentage among the regions. As with the Colorado region, the large percent of deep flow is probably caused by the unequal areal distribution of recharge and discharge. This region is larger than the RASA model region on the west and east sides (fig. 43) and has a different boundary in the area of Monitor Valley Northern Part (HA 140A) and Monitor Valley Southern Part (HA 140B). The region incorporates most of five groundwater flow systems of Harrill and others (1988).

\section{Comparison to RASA Numerical Model}

The RASA study (Harrill and others, 1988; Harrill and Prudic, 1998) and model (Prudic and others, 1995) formed the basis for most subsequent conceptualizations of groundwater flow in the Great Basin. Because the RASA model is the only other model that incorporates most of the study area, similarities and differences in the simulated groundwater budgets and directions of groundwater flow are discussed in the following sections. The models each incorporate the conceptual understanding of the flow system at the time of model construction and calibration, and differences in the models reflect differences in the conceptualizations of Harrill and Prudic (1988) and Heilweil and Brooks (2011). Specifically, differences in the models include (1) smaller cells in the GBCAAS model, (2) recharge more concentrated in the mountains in the GBCAAS model, (3) observations and simulated values in the GBCAAS model that indicate mounding in areas with large rates of recharge, and (4) inclusion of the hydrogeologic framework in the GBCAAS model.

\section{Groundwater Budgets}

The GBCAAS conceptual budget is larger than the RASA conceptual budget. For the 17 groundwater flow systems in the GBCAAS study area, the RASA study estimated recharge of 3,400,000 acre-ft/yr (Harrill and Prudic, 1998, table 4), and the GBCAAS conceptual study estimated recharge of 4,500,000 acre-ft/yr (Masbruch and others, 2011a, table D-1). This is a 32-percent increase in the groundwater budget. This difference in recharge between the two studies is reflected in the simulated budgets. Within the RASA model boundary, the RASA model simulates a groundwater budget of $1,500,000$ acre-ft/yr, and the GBCAAS model simulates a groundwater budget of 2,100,000 acre-ft/yr (table 14). This is a 40-percent increase in the simulated groundwater budget within the RASA model boundary.

Prudic and others (1995) presented simulated budgets for five flow regions that were delineated to have minimal simulated flow between them. The boundaries for the RASA model regions (fig. 43) were used by ZONEBUDGET (Harbaugh, 1990) to calculate simulated budgets in the GBCAAS model for the same flow regions. A comparison of simulated budgets in RASA model regions for both models indicates that the increase in the groundwater budget is not evenly distributed, that subsurface flow between regions is different, and that flow from outside the RASA model has regional significance (table 14). 
Table 14. Comparison of simulated groundwater budgets in the Regional Aquifer-System Analysis (RASA) model to simulated groundwater budgets within the RASA model boundary in the numerical groundwater flow model, Great Basin carbonate and alluvial aquifer system study area.

[All flows in acre-feet per year rounded to two significant figures. Subsurface inflow and outflow: Net flow across boundary. Abbreviations: RASA, Regional Aquifer-System Analysis (Prudic and others, 1995, table 9); GBCAAS, Great Basin carbonate and alluvial aquifer system; —, not applicable]

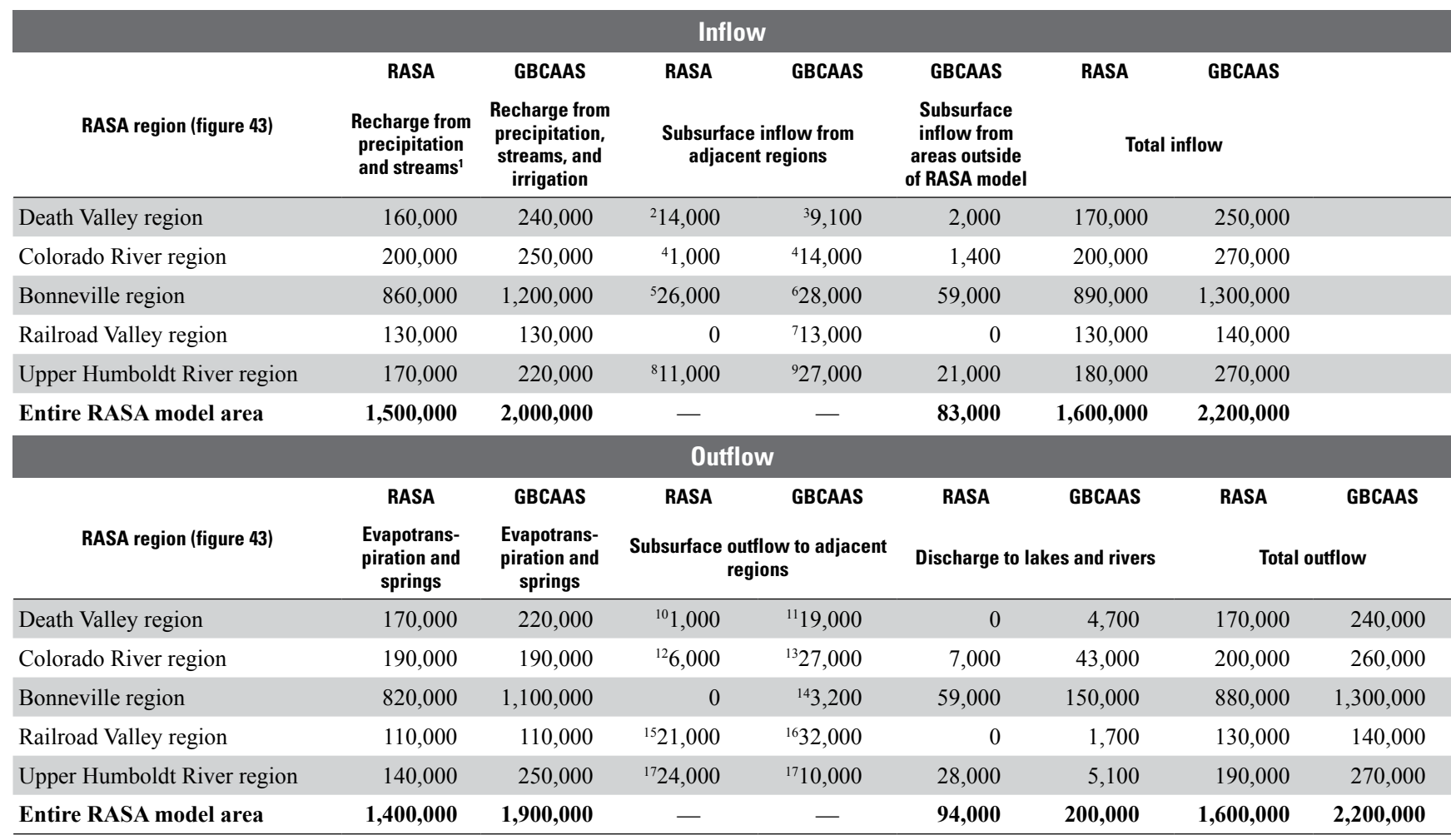

${ }^{1}$ RASA model simulates recharge from streams only in the Upper Humboldt River region, where it is 3,000 acre-feet per year.

${ }^{2}$ 6,000 acre-feet per year from Colorado River region and 8,000 acre-feet per year from Railroad Valley region.

${ }^{3}$ From Colorado River region.

${ }^{4}$ From Railroad Valley region.

${ }_{5}^{5}$ 2,000 acre-feet per year from Railroad Valley region and 24,000 acre-feet per year from Upper Humboldt River region.

${ }^{6} 18,000$ acre-feet per year from Colorado River region and 10,000 acre-feet per year from Upper Humboldt River region.

7 9,400 acre-feet per year from Death Valley region and 3,200 acre-feet per year from Bonneville region.

${ }^{8} 10,000$ acre-feet per year from Railroad Valley region and 1,400 acre-feet per year from Death Valley region.

${ }^{9} 17,000$ acre-feet per year from Railroad Valley region and 9,200 acre-feet per year from Death Valley region.

${ }^{10}$ To Upper Humboldt River region.

${ }^{11}$ 9,200 acre-feet per year to Upper Humboldt River region and 9,400 acre-feet per year to Railroad Valley region.

${ }^{12}$ To Death Valley region.

${ }^{13} 9,100$ acre-feet per year to Death Valley region and 18,000 acre-feet per year to Bonneville region.

${ }^{14}$ To Railroad Valley region.

${ }^{15}$ 2,000 acre-feet per year to Bonneville region, 8,000 acre-feet per year to Death Valley region, 10,000 acre-feet per year to Upper Humboldt River region, and 1,000 acrefeet per year to Colorado River region.

${ }^{16} 17,000$ acre-feet per year to Upper Humboldt River region and 14,000 acre-feet per year to Colorado River region.

${ }^{17}$ To Bonneville region.

In the RASA model Death Valley region, the GBCAAS model simulates 50 percent more recharge and 32 percent more discharge to ETg, springs, lakes, and rivers. Some of the increased discharge is because Prudic and others (1995, p. D61) reduced the estimate of discharge to the playa in Death Valley (HA 243) to account for not including possible recharge west of Death Valley in the RASA model. The GBCAAS model simulates net subsurface outflow to other regions (table 14). The RASA model simulates a net subsurface inflow from other regions, with the most significant difference being inflow from the Railroad Valley region in the
RASA model and outflow to the Railroad Valley region in the GBCAAS model (table 14).

In the RASA model Colorado River region, the GBCAAS model simulates 25 percent more recharge; 18 percent more discharge to ETg, springs, lakes, and rivers; and more subsurface inflow and outflow than the RASA model (table 14). The large difference in discharge to lakes and rivers in the two models is because the GBCAAS model includes springs near Littlefield, Arizona (pl. 1) as discharge to the Virgin River (Heilweil and Brooks, 2011, Auxiliary 3K). These springs were not included in the RASA model (Prudic and others, 
1995, p. D70). Other significant differences in the models are the larger amount of inflow from the Railroad Valley region and the large amount of outflow to the Bonneville region in the GBCAAS model. The GBCAAS model regions (fig. 43) have different boundaries in these areas, which reduce the amount of flow across these boundaries.

In the RASA model Bonneville region, the GBCAAS model simulates 40 percent more recharge; 42 percent more discharge to ETg, springs, lakes and rivers; and similar net subsurface inflow and outflow (table 14). The most significant difference is the larger discharge to lakes and rivers in the GBCAAS model. This is partly the result of including mountain streams in the GBCAAS model, and partly the result of having the complete drainages for Utah Lake and Great Salt Lake (pl. 1) included in the model. Inclusion of the complete drainages provides the GBCAAS model more water to discharge at these lakes, even in just their western portions that correspond to the RASA model. The GBCAAS model simulates subsurface inflow of 59,000 acre-ft/yr (table 14) across the east and north RASA model boundaries in this region, indicating that recharge from areas outside the RASA model boundary contributes to discharge near Utah Lake and Great Salt Lake, and has regional significance.

In the RASA model Railroad Valley region, the GBCAAS model simulates the same amount of recharge and discharge as the RASA model, but substantially larger values of subsurface inflow and outflow (table 14). The large amount of subsurface outflow in both models indicates that the RASA model region is not defined well enough to have minimal connection with other regions. The GBCAAS model region in this area is significantly different from the RASA model region (fig. 43) and has little inflow and outflow (table 12).

In the RASA model Upper Humboldt River region, the GBCAAS model simulates 29 percent more recharge and 52 percent more discharge to ETg, springs, lakes, and rivers (table 14). Similar to the Bonneville region, the large difference in discharge is partly because the RASA model only incorporated part of the drainage area. The GBCAAS model simulates subsurface inflow of 21,000 acre-ft /yr (table 14) across the north and west RASA model boundaries in this region, indicating that recharge from areas outside the RASA model boundary contributes to groundwater discharge near the Humboldt River and has regional significance. Part of the large difference in discharge to lakes and rivers (table 14) is because the GBCAAS model included discharge to a large spring area near Elko, Nevada (spring gElko in table A3-1) as a spring. The RASA model did not include it as a spring (Prudic and others, 1995, fig. 11), but may have included the amount as discharge to the Humboldt River. The GBCAAS model simulates a net subsurface inflow from other areas. The RASA model simulates a net outflow to other regions (table 14), but this is partly because of the large cell size in the RASA model (Prudic and others, 1995, p. D92). The GBCAAS model region in this area incorporates a larger area than the Upper Humboldt River region in the RASA model (fig. 43) and has minimal subsurface inflow and outflow (table 12).

\section{Simulated Water-Level Contours}

The simulated contours and flow directions in the two models are similar, but the GBCAAS model has more variation in the hydraulic gradient (pl. 1; Prudic and others, fig. 19). This difference is mostly caused by the smaller cell size in the GBCAAS model (1 mi x $1 \mathrm{mi}$ in GBCAAS; $5 \mathrm{mi} \mathrm{x} 7.5 \mathrm{mi}$ in RASA) and the use of BCM to estimate recharge. These combine to create higher recharge rates in more concentrated areas in the mountains in the GBCAAS model than in the RASA model. The highest recharge rate in the GBCAAS model is $4.21 \mathrm{ft} / \mathrm{yr}$ (fig. 24); the highest recharge rate in the RASA model is $0.55 \mathrm{ft} / \mathrm{yr}$ (Prudic and others, 1995, fig. 14). This concentrated recharge is likely to cause more hydraulic flow divides at mountain ranges with substantial recharge and to require a different distribution of hydraulic properties to distribute this water. The incorporation of mountain water levels by using rivers and springs in the GBCAAS model may also create different simulated hydraulic properties and higher water levels in the mountains than in the RASA model.

\section{Comparison to DVRFS Numerical Model}

The DVRFS study updated estimates of discharge and recharge, and integrated all available information in the region to provide an improved understanding of regional groundwater flow in the Death Valley region of southern Nevada and California (Belcher, 2004; Belcher and Sweetkind, 2010). The GBCAAS model used water levels and discharge estimates from the DVRFS study as observations in the development and calibration of the model, but did not use hydraulic properties or recharge directly from the DVRFS model. The GBCAAS model has larger cells and fewer layers than the DVRFS model (Faunt and others, 2004) and may not represent local horizontal or vertical gradients as accurately as the DVRFS model. The DVRFS model is transient and provides estimates of storage properties that are not provided by the steady-state GBCAAS model. The incorporation in the GBCAAS model of a larger area, however, may provide boundary conditions for the DVRFS model that better account for surrounding hydrologic features. The use of artificial constant-head boundaries in the DVRFS model also limits its use in evaluating the effects of increased groundwater development near the boundary (Reilly and Harbaugh, 2004). The GBCAAS model would not have those limitations, but could only estimate ultimate effects on water levels and natural discharge at a new steady-state condition because it does not incorporate storage and transient changes. Because of possible differences in recharge, hydraulic properties, and boundary conditions, a comparison was made between the GBCAAS model and the DVRFS model. 


\section{Groundwater Budget}

The overall budgets for the GBCAAS model and the DVRFS model (Faunt and others, 2004) are within 3 percent of each other (table 15), but the GBCAAS model has more recharge within the DVRFS and less flow across DVRFS boundary segments (fig. 44) than the DVRFS model. The boundary flows estimated in the DVRFS study (Harrill and Bedinger, 2004) were not considered during calibration of the GBCAAS model, but are provided in this report for comparison (table 15). The largest difference in simulated flows across the boundary is on the west edge of the models where the DVRFS model simulates constant-head boundaries (Faunt and others, 2004, table F-2) and the GBCAAS model simulates noflow boundaries. Inflow along this boundary was not needed to match observations in the GBCAAS model.
Other differences occur on the north and south boundaries of the DVRFS model. The GBCAAS model has less flow across the northern boundaries than the DVRFS model (table 15). This is consistent with water-level contours that indicate flow to Railroad Valley Northern Part (HA 173B; pl. 1; Heilweil and Brooks, 2011, pl. 2). The DVRFS model simulates the Spring-Mesquite boundary segment in the southern part of the model as a no-flow boundary, but the GBCAAS model has outflow through this boundary segment. This is consistent with water-level contours (pl. 1; Heilweil and Brooks, 2011, pl. 2) that indicate flow from Pahrump Valley (HA 162) to Mesquite Valley (HA 163).

The models have similar amounts of outflow to the east, but the GBCAAS model distributes the flow more evenly along the eastern boundary with less flow across the northern

Table 15. Comparison of simulated steady-state groundwater budgets in the Death Valley regional flow system numerical groundwater flow model and the current numerical groundwater flow model, Great Basin carbonate and alluvial aquifer system study area.

[Amounts rounded to three significant figures. Amounts for Death Valley estimate for recharge and discharge to evapotranspiration and springs from Faunt and others, 2004, table F-18. Amounts for Death Valley estimate of flows at boundary segments from Harrill and Bedinger, 2004 , table A2-9. Amounts for Death Valley model from Faunt and others, 2004, table F-18. Abbreviations: GBCAAS, Great Basin carbonate and alluvial aquifer system; <, less than]

\begin{tabular}{|c|c|c|c|c|c|c|}
\hline & \multicolumn{2}{|c|}{ Death Valley estimate } & \multicolumn{2}{|c|}{ Death Valley model } & \multicolumn{2}{|c|}{ GBCAAS model } \\
\hline & $\begin{array}{c}\text { cubic meters } \\
\text { per day }\end{array}$ & $\begin{array}{l}\text { acre-feet } \\
\text { per year }\end{array}$ & $\begin{array}{c}\text { cubic meters } \\
\text { per day }\end{array}$ & $\begin{array}{l}\text { acre-feet } \\
\text { per year }\end{array}$ & $\begin{array}{l}\text { cubic feet } \\
\text { per day }\end{array}$ & $\begin{array}{l}\text { acre-feet } \\
\text { per year }\end{array}$ \\
\hline \multicolumn{7}{|c|}{ Inflow } \\
\hline Recharge & ${ }^{1}<342,000$ & $<101,000$ & 303,000 & 89,900 & $13,700,000$ & 115,000 \\
\hline \multicolumn{7}{|c|}{ Inflow from west ${ }^{2}$} \\
\hline Panamint boundary segment & 15,000 & 4,440 & 25,400 & 7,520 & 137,000 & 1,150 \\
\hline \multicolumn{7}{|c|}{ Inflow from north } \\
\hline Clayton boundary segment & 667 & 198 & 7,150 & 2,120 & $-62,100$ & -520 \\
\hline Stone Cabin-Railroad boundary segment & 12,500 & 3,700 & 81,500 & 24,100 & $1,340,000$ & 11,200 \\
\hline \multicolumn{7}{|c|}{ Inflow from south } \\
\hline Silurian boundary segment & 500 & 148 & $-1,550$ & -459 & 96,200 & 807 \\
\hline Total inflow & $<392,000$ & $<116,000$ & 448,000 & 133,000 & $15,400,000$ & 129,000 \\
\hline \multicolumn{7}{|c|}{ Outflow } \\
\hline Discharge to evapotranspiration and springs & 342,000 & 101,000 & 362,000 & 107,000 & $12,100,000$ & 101,000 \\
\hline \multicolumn{7}{|c|}{ Outflow to east } \\
\hline Pahranagat boundary segment & 2,780 & 823 & 38,200 & 11,300 & 719,000 & 6,030 \\
\hline Sheep Range boundary segment & 18,700 & 5,540 & 47,400 & 14,000 & $1,010,000$ & 8,460 \\
\hline Las Vegas boundary segment & 4,580 & 1,360 & 1,400 & 415 & 902,000 & 7,570 \\
\hline \multicolumn{7}{|c|}{ Outflow to southeast } \\
\hline Spring-Mesquite boundary segment & 0 & 0 & 0 & 0 & 669,000 & 5,610 \\
\hline
\end{tabular}

${ }^{1}$ Total net infiltration from Hevesi and others (2003). Not used as an observation in Death Valley model.

${ }^{2}$ In the GBCAAS model, the flow from the west is because of a slight difference in model boundaries, not because of specified inflow or inflow from constant-head or general-head boundaries.

${ }^{3}$ In the GBCAAS model, the flow across the Owlshead boundary is because of a slight difference in model boundaries, not because of specified inflow or inflow from constant-head or general-head boundaries. 


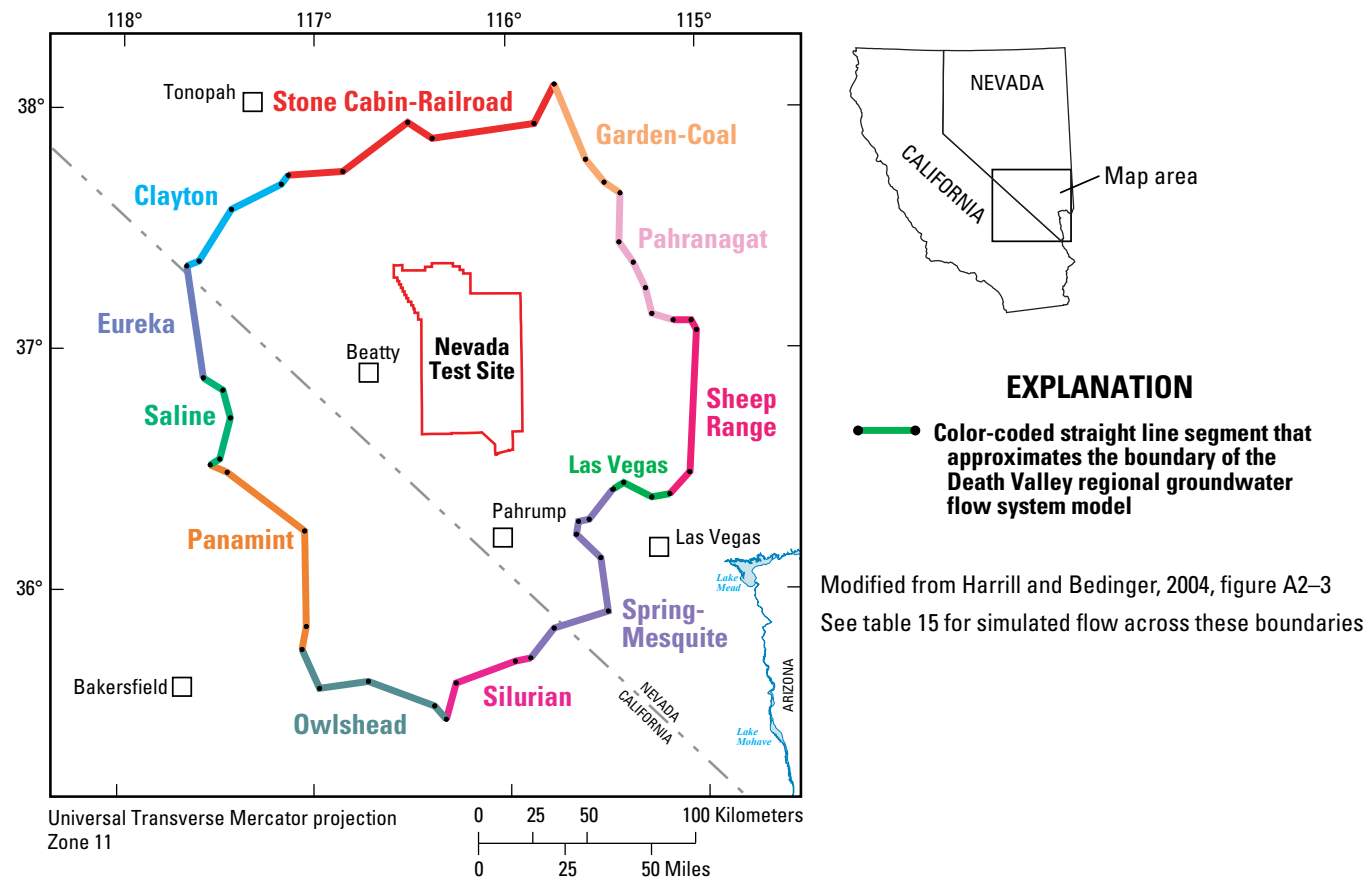

Figure 44. Death Valley regional groundwater flow system model boundary segments, Nevada and California.

segments and more flow across the southern Las Vegas boundary segment (table 15). The large amount of flow across the east boundary is consistent with water-level contours (pl. 1; Heilweil and Brooks, 2011, pl. 2) and with Faunt and others (2004, p. 344). The divide between the DVRFS and the Colorado groundwater flow system (34) may be west of the DVRFS model boundary in this area.

\section{Simulated Water-Level Contours}

Water-level contours (pl. 1; Faunt and others, 2004, fig. F-46) are similar in the two models, and major differences are limited to the edges of the DVRFS model. The following major features are represented in both models:

1. The steep gradient at the north and west edges of Yucca Flat (HA 159) and extending west to Death Valley (HA 243). Neither model adequately simulates the steepness of the gradient, and simulated levels typically are too low north of the gradient and too high south of the gradient (pl. 1; Faunt and others, 2004, p. 345).

2. The extended area of very flat gradient from the south end of Yucca Flat (HA 159) and the western portions of Three Lakes Valley Northern Part (HA 168) and Three Lakes Valley Southern Part (HA 211) to Amargosa Desert (HA 230) .

3. The high water levels and steep gradient in the Spring Mountains west of Pahrump Valley (HA 162).
4. The simulated groundwater divide between the Death Valley and Colorado groundwater flow systems is west of the Pahranagat and Sheep Range boundary segments. Because of the location of the divide, both models simulate little or no flow from the area of the Pahranagat boundary segment to the springs in Amargosa Desert (HA 230; Faunt and others, 2004, p. 344).

5. Downward gradients in recharge areas and upward gradients in discharge areas (fig. 41; Faunt and others, 2004, p. 333).

6. Upward gradient in parts of Forty Mile Canyon Jackass Flats (HA 227A; fig. 41; Faunt and others, 2004, p. 333).

Major differences occur near some boundaries of the models that are related to boundary conditions. Because the GBCAAS model has the western boundary as a no-flow boundary and has more recharge than the DVRFS model, higher water levels occur at the western boundary in the GBCAAS model. For example, west of the main ETg areas in Death Valley (HA 243), the GBCAAS model has simulated heads up to about $3,800 \mathrm{ft}$ (pl. 1), and the DVRFS model has heads of about $650 \mathrm{ft}$ (Faunt and others, 2004, fig. F-46).

Differences also exist at the north end of Death Valley (HA 243). The GBCAAS model has a steep hydraulic gradient in order to maintain high enough water levels in Fish Lake Valley (HA 117) and Clayton Valley (HA 143) to match the ETg observations in those valleys (table A3-1). This gradient is obtained by using a small transmissivity in the area (fig. 40). The DVRFS model did not include Fish Lake Valley (HA 117) and Clayton Valley (HA 143), and therefore, did not have 
to match discharge to ETg in those valleys. The GBCAAS model (pl. 1) has heads ranging from 5,300 $\mathrm{ft}$ at the west end of this boundary to $4,800 \mathrm{ft}$ at the east end between Clayton Valley (HA 143) and Lida Valley (HA 144), indicating flow away from the recharge area near the west model boundary. The DVRFS model has simulated heads ranging from $3,940 \mathrm{ft}$ on the west to 4,600 ft on the east (Faunt and others, 2004, fig. F-46), indicating a lower gradient than the GBCAAS model and flow toward the west model boundary.

Differences in simulated water levels also exist at the northern-most extension of the DVRFS model in Penoyer Valley (HA 170) and at the eastern-most extension of the DVRFS model in Three Lakes Valley Southern Part (HA 211), where the GBCAAS model has higher water levels because of recharge on mountains and the DVRFS model has constanthead boundaries.

\section{Model Limitations}

This model was developed to simulate general groundwater flow throughout the GBCAAS. It was not developed to simulate local effects of withdrawals or water budgets on a cell-by-cell basis. All groundwater flow models are based on a limited amount of data and are simplifications of natural systems. Because of scale, a model of a large region requires more simplification in geology and representation of recharge and discharge boundaries than do models of smaller regions. The relatively undeveloped region simulated by the GBCAAS model has sparse data in large areas of the model, including data about aquifer properties, discharge locations, and water levels. These simplifications and data scarcity limit the ability of the model to simulate the natural system accurately, especially at local scales and possibly in areas with less data. Model limitations are a consequence of simplifications, inadequacies, or inaccuracies in (1) representation of the geologic complexity in the hydrogeologic framework and model, (2) representation of recharge and discharge boundaries, and (3) observations used in the model.

\section{Hydrogeologic Framework and Model Grid Limitations}

The ability of the numerical model to simulate flow accurately depends on the accuracy and representation of the hydrogeologic framework. Limitations exist in the numerical flow model because of the difficulties inherent in the interpretation and representation of the complex geometry and spatial variability of hydrogeologic materials and structures in the hydrogeologic framework and because of the application of that framework to a 1-mi model cell size. Abrupt changes in rock type and conductivity cannot be represented at the exact position and small but important features may be missed completely at this scale. A single preferred hydrogeologic framework (Heilweil and Brooks, 2011) is simulated; alternative interpretations were not simulated but are possible.
Incorporating the spatial variability of hydraulic properties and structures (Sweetkind and others, 2011a) in the numerical model substantially improved the simulation. The model, however, remains a significantly simplified version of reality. Detailed stratigraphy not represented in the hydrogeologic framework may cause some of the mismatch between simulated and observed hydraulic gradients and heads. In the numerical model, the assumption of homogeneity within a given HGU or hydraulic-conductivity zone removes the potential effects of smaller scale variability. The delineation of zones of hydraulic conductivity and the selection of faults to simulate with the HFB Package (Hsieh and Freckleton, 1993) were selected to match the observations. It is possible that different zone boundaries could be selected that would provide a similar or better model fit and that additional zones exist that are not simulated because geologic or hydrologic data are not available to delineate them. It is also possible that faults that are not simulated with the HFB Package could act as similar barriers to groundwater flow, but that water-level data are not available to delineate these areas, or that an HFB may be misrepresented at the edge of a cell instead of in the middle of a cell.

The HUF Package (Anderman and Hill, 2000) introduces some error in the representation of the system, as does any method to assign geologic properties to a regular grid. Thin layers of either permeable or relatively impermeable materials may not exert as much influence in the simulation as in the groundwater system because the HUF Package assigns the average hydraulic conductivity of the HGUs in each cell to each cell.

\section{Recharge and Discharge Boundary Limitations}

The large cell size causes some error in the accurate representation of recharge and discharge boundaries, as does the assignment of zones of the boundaries to parameters. It is possible that different zone boundaries could be selected that would provide a similar or better model fit. Recharge and discharge, especially ETg, probably vary more across the assigned zones than is simulated. For instance, recharge is dependent on vertical hydraulic conductivity of the material both at the surface and at the water table. Horizontal flow can occur at either of these locations until a more permeable material is encountered. ETg is simplified in the model by assigning the same rate to each ETg boundary in an HA. In the natural system, ETg varies by vegetation type, vegetation density, and microclimate conditions at the land surface. These limitations affect the accuracy of the model mostly at local scales, but should have limited regional effects. 


\section{Observation Limitations}

Observations of water levels and groundwater discharge constrain model calibration through parameter estimation. Uncertainty in these observations introduces uncertainty in the results of the numerical model. Although the water-level and discharge observations used in this model were analyzed prior to and throughout calibration, there was uncertainty regarding the distribution, quality, and interpretation of the observation data.

Most water-level data are available for the eastern part of the study area, Las Vegas Valley (HA 212), and areas within the DVRFS. The clustering of water-level observations in these areas may limit the parameter estimation because sparse observations in other parts of the study area may be ignored (Hill and Tiedeman, 2007, p. 285). The effect of clustering was minimized by using a selected set of water-level data for observations as explained in the "Observations Used in Model Calibration" section of this report, resulting in a more even distribution of water-level observations (pl. 1). The model parameters are more uncertain in areas with limited observation data, and new data could indicate that revisions in the model are needed in those areas.

Some water-level observations used in the steady-state calibration may be affected by groundwater development. Because many wells in the area were drilled at the start of, or after, groundwater development, it is difficult to assess which observations best represent pre-pumping conditions. It is also difficult to assess whether certain water-level observations represent the regional water table or local perched-water conditions. Areas of steep hydraulic gradient, which are important features in the regional groundwater flow system, also may be an artifact of perched water levels. Incorrect water-level observations should have only local effects on model parameters.

ETg observations were computed on the basis of vegetated areas and reported or measured rates of evapotranspiration (Masbruch and others, 2011, p. 98-101). Estimates of the amount of discharge that may have occurred prior to groundwater development (Masbruch and others, 2011, p. 104-105; Masbruch, 2011b, table A5-1) are used as observations in this model. Errors may exist in these estimates. For example, the estimates assume that all reported pumping at the time of the evapotranspiration estimate had captured natural discharge and that no water was continuing to be released from groundwater storage (Masbruch and others, 2011, p. 99); this may have resulted in overestimating predevelopment evapotranspiration in some HAs. Error in these observations will affect the estimation of recharge and hydraulic conductivity parameters.

\section{Appropriate Uses of the Model}

The GBCAAS model was developed for the purpose of simulating regional-scale groundwater flow. The intent was not to reproduce every detail of the hydrogeologic system, but to portray its general characteristics. The most appropriate use of this model is to investigate groundwater flow issues at that scale. Examples of its potential use to investigate the natural system include (1) the ultimate effects of different recharge throughout the area or large parts of the area, (2) different interpretations of the extent or offset of faults or fault zones, or (3) different conceptual models of depositional environments or tectonic/structural events that would affect the spatial variation of hydraulic properties.

The model can also be used to examine the ultimate effects of groundwater withdrawals on a regional scale if withdrawals are added to the model. Increasing population in southern Nevada and along the eastern edge of the study area in Utah necessitates the development of groundwater resources, and the model can be used for examining the effects of this development on the regional groundwater flow system and natural groundwater discharge. It is inappropriate to use the model to investigate questions associated with individual wells or local withdrawals. This model is a steady-state model; it does not include storage properties and storage properties were not estimated as part of this project. The model cannot be used to evaluate the timing of the effects of increased withdrawals or other changes, only the long-term (ultimate) results.

Additional uses of the model are to provide boundary conditions for local-scale models and guide data collection for new studies. Local-scale models can be refined to represent local conditions more accurately, but consistency between regional and local-scale models must be maintained to ensure accurate simulations. For instance, using a regional model to determine boundary heads and then making extensive changes in hydraulic conductivity in a local model may allow more or less flow through a local model than would occur in a regional model. Programs such as MODFLOW-LGR (Mehl and Hill, 2005), which allows for local grid refinement or MODFLOW-USG (Panday and others, 2013), which allows for a variably spaced grid, may be used to derive boundary conditions for local-scale models that stay consistent with regional models.

The model and statistics from programs such as UCODE_2005 (Poeter and others, 2008) and OPR-PPR (Tonkin and others, 2007) can be used to guide data collection that will be the most useful in reducing prediction uncertainty. The model can be used less formally to guide data collection by consideration of zonation and parameter values that were needed to achieve calibration in selected areas and what data could be collected to verify or dispute the model parameters. 


\section{Summary}

This report describes the construction, calibration, evaluation, and results of a steady-state numerical groundwater flow model of the Great Basin carbonate and alluvial aquifer system (GBCAAS) study area. The study area spans a large, topographically, geologically, and climatologically diverse region that covers $110,000 \mathrm{mi}^{2}$ across five states. The study area is experiencing rapid population growth and has some of the highest per capita water use in the United States, resulting in increased demand for groundwater. The numerical model uses MODFLOW-2005, and incorporates and tests complex hydrogeologic and hydrologic elements of a conceptual understanding of an interconnected groundwater system throughout the region, including mountains, basins, consolidated rocks, and basin fill. A broader purpose of the model is to assess regional groundwater resources in the context of the complete groundwater budget, and to allow for the assessment of changes in groundwater availability at a regional scale.

Aquifer geometry and structural features are integral to the simulation of groundwater flow in the study area. A digital, three-dimensional hydrogeologic framework was constructed to represent the subsurface configuration of hydrogeologic units and major geologic structures in the study area. The complex stratigraphy has been simplified to nine hydrogeologic units that differ in their ability to store and transmit water; the carbonate rocks and basin fill are the most permeable units and important aquifers. The groundwater flow model consists of eight model layers that do not coincide with the nine hydrogeologic units. The geometries of the hydrogeologic units in this system are complex because of considerable folding, faulting, and other processes, and it is not possible for model layers to conform to these irregular shapes. The HUF Package is used to define the hydrogeologic units for the simulation and to define transmissivity in the model. Faults that appear to create a barrier to flow are simulated using the HFB Package.

Recharge from precipitation, irrigation, and streams and discharge to evapotranspiration, springs, rivers, and lakes are simulated. Previous studies have assumed that the regional water table is below the altitude of mountain springs and streams, but this model simulates discharge in mountain areas.

Observations used to calibrate the model are those of water levels and discharge to evapotranspiration, springs, rivers, and lakes. Calibration relied on formal parameter-estimation methods using UCODE_2005 and on manual calibration. Composite scaled sensitivities indicate the simulated values of discharge to springs, rivers, and lakes provide as much information about model parameters as do water-level observations. The model has 176 parameters, of which 164 were estimated at some point during the calibration process. Confidence intervals of parameters indicate the simulated values provide enough information to constrain most parameters to smaller ranges than the conceptual constraints, and that most parameter values are within reasonable ranges. Final model parameters have little correlation, which indicates that the parameters can be determined independently of each other.
As part of model evaluation, the model fit to observations, comparison of simulated to conceptual water-level contours, and comparison of simulated to conceptual water budgets were evaluated. Results of this evaluation indicate the model provides a reasonable representation of the regional groundwater system. The fit of simulated to observed water levels and discharge is good. Eighty-six percent of the simulated values of observations of water levels in wells are within 119 feet (one standard deviation of the error) of the observed values, and 50 percent of them are within 40 feet of the observed values. Ninety percent of the simulated discharges are within 30 percent of the observed values, and 95 percent are within 50 percent of the observed values. Total simulated recharge in the study area is within 10 percent of the conceptual amount; total simulated discharge is the same as conceptual discharge.

Comparison of simulated hydraulic heads with the conceptual potentiometric surface indicates that the model accurately depicts major features of the hydraulic-head distribution. The general flow patterns of recharge in high-altitude areas and movement toward five major discharge areas is simulated in the model. The concept of the mountains and basins forming a continuous groundwater system provides more detailed contours and flow paths than previous studies focusing on groundwater in the carbonates. The incorporation of Basin Characterization Model (BCM) recharge and of mountain springs and streams as model observations creates higher recharge mounds under many mountain ranges and highlights that many regional flow paths go around, not through (or under), mountain ranges. The mounding and possible diversion of flow paths are not as apparent in areas with less recharge.

Simulating eight model layers and including water-level observations in multiple layers allowed for adequate simulation of vertical gradients. Limited data throughout the study area indicate that gradients are downward in recharge areas and upward in discharge areas, which is simulated in the model. Results from the model show that much of the flow in the groundwater system occurs in deeper layers, even though about 86 percent of the discharge occurs in layer 1. Over 95 percent of the recharge moves down from layer 1, and about 25 percent moves down to layer 8 (the deepest layer).

The model was used to delineate six simulated groundwater flow regions that connect recharge areas to discharge areas. The eastern Great Salt Lake and Great Salt Lake Desert model regions contain 75 percent of the groundwater budget, but only 42 percent of the area. In contrast, the more southern Death Valley and Colorado model regions contain only 12 percent of the groundwater budget, but 37 percent of the study area. These two regions also have a larger percentage of deep flow than other parts of the model.

Because it represents an acceptable simulation of regional groundwater flow, the GBCAAS model can be used for prediction simulations within the interior of the model because the boundaries are distant from many areas of interest. This has not been previously available for much of the study area at this level of discretization. The model can be used as the basis for more detailed or transient models. Examples of potential 
use of the model to investigate the natural system include the following: (1) the effects of decreased recharge throughout the area or large parts of the area caused by drought conditions, (2) different interpretations of the extent or offset of long faults or fault zones, and (3) different conceptual models of depositional environments that would affect the spatial variation of hydraulic properties. The model can also be used to examine the ultimate effects of groundwater withdrawals on a regional scale, to provide boundary conditions for local-scale models, and to guide data collection.

\section{References}

Alley, W.M., Reilly, T.E., and Franke, O.L., 1999, Sustainability of ground-water resources: U.S. Geological Survey Circular 1186, 79 p.

Anderman, E.R., and Hill, M.C., 2000, MODFLOW-2000, the U.S. Geological Survey modular ground-water modelDocumentation of the Hydrogeologic-Unit Flow (HUF) Package: U.S. Geological Survey Open-File Report, 2000-342, 89 p.

Anderman, E.R., and Hill, M.C., 2003, MODFLOW-2000, the U.S. Geological Survey modular ground-water modelThree additions to the Hydrogeologic-Unit Flow (HUF) Package: Alternative storage for the uppermost active cells, Flows in hydrogeologic units, and the Hydraulic-conductivity depth-dependence (KDEP) capability: U.S. Geological Survey Open-File Report, 2003-347, 36 p.

Baker, Jr., C.H., 1974, Water resources of the Curlew Valley drainage basin, Utah and Idaho: Utah Department of Natural Resources Technical Publication No. 45, 91 p.

Banta, E.R., and Provost, A.M., 2008, User guide for HUFPrint, a tabulation and visualization utility for the Hydrogeologic-Unit Flow (HUF) Package of MODFLOW: U.S. Geological Survey Techniques and Methods 6-A27, 13 p.

Barlow, P.M., and Leake, S.A., 2012, Streamflow depletion by wells-Understanding and managing the effects of groundwater pumping on streamflow: U.S. Geological Survey Circular 1376, $84 \mathrm{p}$.

Beck, D.A., and Wilson, J.W., 2006, Discharge and physical-property measurements from Virgin River Narrows, Arizona, to Lake Mead, Nevada, February 12, 2003: U.S. Geological Survey Scientific Investigations Report 20055286, $10 \mathrm{p}$.

Bedinger, M.S., and Harrill, J.R., 2004, Regional potential for interbasin flow of ground water, appendix 1 of Belcher, W.R., ed., Death Valley regional ground-water flow system, Nevada and California-Hydrologic framework and transient ground-water flow model: U.S. Geological Survey Scientific Investigations Report 2004-5205, p. 357-374.
Belcher, W.R., ed., 2004, Death Valley regional ground-water flow system, Nevada and California-Hydrogeologic framework and transient ground-water flow model: U.S. Geological Survey Scientific Investigations Report 2004-5205, 408 p., http://pubs.usgs.gov/sir/2004/5205/

Belcher, W.R., Bedinger, M.S., Back, J.T., and Sweetkind, D.S., 2009, Interbasin flow in the Great Basin with special reference to the southern Funeral Mountains and the source of Furnace Creek springs, Death Valley, California, U.S.: Journal of Hydrology, v. 369, p. 30-43.

Belcher, W.R., and Sweetkind D.S., eds., 2010, Death Valley regional groundwater flow system, Nevada and CaliforniaHydrogeologic framework and transient groundwater flow model: U.S. Geological Survey Professional Paper 1711, 398 p., http://pubs.usgs.gov/pp/1711/.

Belcher, W.R., Sweetkind, D.S., and Elliot, P.E., 2002, Probability distributions of hydraulic conductivity for the hydrogeologic units of the Death Valley regional groundwater flow system, Nevada and California: U.S. Geological Survey Water-Resources Investigations Report 02-4212, $18 \mathrm{p}$.

Berger, D.L., 2000, Water budgets for Pine Valley, Carico Lake Valley, and Upper Reese River Valley hydrographic areas, middle Humboldt River Basin, north-central Nevada: Methods for estimation and results: U.S. Geological Survey Water-Resources Investigations Report 99-4272, 43 p.

Bergquist, G., 1994, Per capita water use, in Strategic Assessment of Florida's Environment (SAFE): Florida Department of Environmental Protection, Tallahassee, Florida, p. 278-281.

Bjorklund, L.J., and McGreevy, L.J., 1971, Ground-water resources of Cache Valley, Utah and Idaho: Utah Department of Natural Resources Technical Publication 36, 144 p.

Bjorklund, L.J., and McGreevy, L.J., 1974, Ground-water resources of the Lower Bear River drainage basin, Box Elder County, Utah: Utah Department of Natural Resources Technical Publication 44, $65 \mathrm{p}$.

Brenner, I.S., 1974, A surge of maritime tropical air-Gulf of California to southwestern United States: Monthly Weather Review, v. 102, p. 375-389.

Brooks, L.E., and Mason, J.L., 2005, Hydrology and simulation of ground-water flow in Cedar Valley, Iron County, Utah: U.S. Geological Survey Scientific Investigations Report 2005-5170, $114 \mathrm{p}$.

Brooks, L.E., and Stolp, B.J., 1995, Hydrology and simulation of ground-water flow in southern Utah and Goshen Valleys, Utah: Utah Department of Natural Resources Technical Publication 111, $96 \mathrm{p}$. 
Buto, S.G., 2011, Description of spatial datasets accompanying the conceptual model of the Great Basin carbonate and alluvial aquifer system, appendix 6 of Heilweil, V.M., and Brooks, L.E., eds., Conceptual model of the Great Basin carbonate and alluvial aquifer system: U.S. Geological Survey Scientific Investigations Report 2010-5193, p. $177-179$.

Caine, J.S., Evans, J.P., and Forster, C.B., 1996, Fault zone architecture and permeability structure: Geology, v. 24, p. 1025-1028, doi: 10.1130/0091-7613.

Cardinalli, J.L., Roach, L.M., Rush, F.E., and Vasey, B.J., 1968, State of Nevada hydrographic areas, scale 1:500,000, in Rush, F.E., ed., Index of hydrographic areas: Nevada Division of Water Resources Information Report 6, 38 p.

Cederberg, J.R., Gardner, P.M., and Thiros, S.A., 2009, Hydrology of northern Utah Valley, Utah County, Utah, 1975-2005: U.S. Geological Survey Scientific Investigations Report 2008-5197, 114 p.

Cederberg, J.R., Sweetkind, D.S., Buto, S.G., and Masbruch, M.D., 2011, Three-dimensional hydrogeologic framework, appendix 1 of Heilweil, V.M., and Brooks, L.E., eds., Conceptual model of the Great Basin carbonate and alluvial aquifer system: U.S. Geological Survey Scientific Investigations Report 2010-5193, p. 127-142.

Chilingarian, G.V., Mazzullo, S.J., and Rieke, H.H., eds., 1996, Carbonate reservoir characterization: A geologicengineering analysis, part II: Developments in Petroleum Science, v. 44, New York, Elsevier Science, 992 p.

Christensen, S., and Cooley, R.L., 1999, Evaluation of confidence intervals for a steady-state leaky aquifer model: Advances in Water Resources, v. 22, no. 8, p. 807-817.

Cordova, R.M., and Subitzky, 1965, Ground water in northern Utah Valley, Utah: A progress report for the period 1948-63: Utah Department of Natural Resources Technical Publication $11,41 \mathrm{p}$.

Daly, C., Gibson, W.P., Doggett, M., Smith, J., and Taylor, G., 2004, Up-to-date monthly climate maps for the conterminous United States, in Conference on Applied Climatology, 14th, American Meteorological Society 84th Annual Meeting, January 13-16, 2004, Seattle, Paper 5.1.

Daly, C., Halbleib, M., Smith, J.I., Gibson, W.P., Doggett, M.K., Taylor, G.H., Curtis, J., and Pasteris, P.A., 2008, Physiographically sensitive mapping of temperature and precipitation across the conterminous United States: International Journal of Climatology, v. 6, no. 15, p. 2031-2064, doi: 10.1002/joc.1688, accessed March 6, 2008, at http://onlinelibrary.wiley.com/doi/10.1002/joc.1688/abstract.
Dettinger, M.D., and Schaefer, D.H., 1996, Hydrogeology of extended terrains in the eastern Great Basin from geologic and geophysical models: U.S. Geological Survey Hydrologic Investigations Atlas HA-694-D, 1 sheet.

Dinwiddie, G.A., and Schroder, L.J., 1971, Summary of hydraulic testing in and chemical analyses of water samples from deep exploratory holes in Little Fish Lake, Monitor, Hot Creek, and Little Smoky Valleys, Nevada: USGS-47490, Technical Letter prepared under agreement no. AT(292) -474 for the Nevada Operations Office, U.S. Atomic Energy Commission.

Dixon, G.L., Rowley, P.D., Burns, A.G., Watrus, J.M., Donovan, D.J., and Ekren, E.B., 2007, Geology of White Pine and Lincoln Counties and adjacent areas, Nevada and Utah: The geologic framework of regional groundwater flow systems: Southern Nevada Water Authority, Las Vegas, Nevada, Doc. No. HAM-ED-0001, 157 p.

Eakin, T.E., 1961, Ground-water appraisal of Pine Valley, Eureka and Elko Counties, Nevada: Nevada Department of Conservation and Natural Resources Ground-Water Resources Reconnaissance Report 2, 41 p.

Eakin, T.E., 1963, Ground-water appraisal of Pahranagat and Pahroc Valleys, Lincoln and Nye Counties, Nevada: Nevada Department of Conservation and Natural Resources Ground-Water Resources Reconnaissance Report 21, 36 p.

Eakin, T.E., and Lamke, R.D., 1966, Hydrologic reconnaissance of the Humboldt River Basin, Nevada: Nevada Department of Conservation and Natural Resources Water Resources Bulletin 32, $107 \mathrm{p}$.

Eakin, T.E., Maxey, G.B., Robinson, T.W., Fredericks, J.C., and Loeltz, O.J., 1951, Contributions to the hydrology of eastern Nevada: State of Nevada Office of the State Engineer Water Resources Bulletin 12, 85 p.

Eakin, T.E., Moore, D.O., and Everett, D.E., 1965, Water resources appraisal of the upper Reese River Valley, Lander and Nye Counties, Nevada: State of Nevada Department of Conservation and Natural Resources Water Resources Reconnaissance Series Report 31, 47 p.

Ely, D.M., and Kahle, S.C., 2004, Conceptual model and numerical simulation of the ground-water-flow system in the unconsolidated deposits of the Colville River watershed, Stevens County, Washington: U.S. Geological Survey Scientific Investigations Report 2004-5237, 72 p.

Environmental Systems Research Institute, 2010, ArcGIS 9.3 Desktop help - Implementing Inverse Distance Weighted (IDW): release 9.3, accessed March 2010, at http://webhelp. esri.com/arcgisdesktop/9.3/index.cfm? TopicName $=I D W$. 
Faunt, C.C., Blainey, J.B., Hill, M.C., D'Agnese, F.A., and O'Brien, G.M., 2004, Transient numerical model, chap. F of Belcher, W.R., ed., Death Valley regional ground-water flow system, Nevada and California-Hydrologic framework and transient ground-water flow model: U.S. Geological Survey Scientific Investigations Report 2004-5205, p. 257-352.

Feltis, R.D., 1967, Ground-water conditions in Cedar Valley, Utah County, Utah: Utah Department of Natural Resources Technical Publication No. 16, 34 p.

Fetter, C.W., 1980, Applied hydrogeology: Columbus, Ohio, Charles E. Merrill Publishing Company, 488 p.

Flint, A.L., Flint, L.E., and Masbruch, M.D., 2011, Input, calibration, uncertainty, and limitations of the Basin Characterization Model, appendix 3 of Heilweil, V.M., and Brooks, L.E., eds., Conceptual model of the Great Basin carbonate and alluvial aquifer system: U.S. Geological Survey Scientific Investigations Report 2010-5193, p. 149-164.

Gardner, P.M., Masbruch, M.D., Plume, R.W., and Buto, S.G., 2011, Regional potentiometric-surface map of the Great Basin carbonate and alluvial aquifer system in Snake Valley and surrounding areas, Juab, Millard, and Beaver Counties, Utah and White Pine and Lincoln Counties, Nevada: U.S. Geological Survey Scientific Investigations Map 3193, 2 sheets.

Gleeson, Tom, and Manning, A.H., 2008, Regional groundwater flow in mountainous terrain: Threedimensional simulations of topographic and hydrogeologic controls: Water Resources Research, v. 44, 16 p., W10403, doi:10.1029/2008WR006848, accessed December 22, 2008, at http://onlinelibrary.wiley.com/ doi/10.1029/2008WR006848/pdf.

Haitjema, Henk, 2003, The role of hand-calculations in groundwater flow modeling, in Poeter, E., Zheng, C., Hill, M., and Doherty, J., organizing committee, MODFLOW and More 2003: Understanding through modeling, Golden, Colorado, [Proceedings], p. 441-445.

Harbaugh, A.W., 1990, A computer program for calculating subregional water budgets using results from the U.S. Geological Survey modular three-dimensional finite-difference ground-water flow model: U.S. Geological Survey OpenFile Report 90-392, 24 p.

Harbaugh, A.W., 2005, MODFLOW-2005, the U.S. Geological Survey modular ground-water model-The groundwater flow process: U.S. Geological Survey Techniques and Methods 6-A16, variously paged.

Harbaugh, A.W., and Hill, M.C., 2009, Obs.pdf provided with MODFLOW-2005 model, accessed February 14, 2013, at http://water.usgs.gov/nrp/gwsoftware/modflow2005/ modflow2005.html.
Harrill, J.R., and Bedinger, M.S., 2004, Estimated model boundary flows, appendix 2 of Belcher, W.R., ed., Death Valley regional ground-water flow system, Nevada and California-Hydrologic framework and transient groundwater flow model: U.S. Geological Survey Scientific Investigations Report 2004-5205, p. 376-408.

Harrill, J.R., Gates, J.S., and Thomas, J.M., 1988, Major ground-water flow systems in the Great Basin region of Nevada, Utah, and adjacent states: U.S. Geological Survey Hydrologic Investigations Atlas 694-C, 2 sheets.

Harrill, J.R., and Prudic, D.E., 1998, Aquifer systems in the Great Basin region of Nevada, Utah, and adjacent states - Summary report: U.S. Geological Survey Professional Paper 1409-A, 66 p.

Heilweil, V.M., and Brooks, L.E., eds., 2011, Conceptual model of the Great Basin carbonate and alluvial aquifer system: U.S. Geological Survey Scientific Investigations Report 2010-5193, 192 p., http://pubs.usgs.gov/sir/2010/5193/.

Heilweil, V.M., and Buto, S.G., 2011, Descriptive information for each hydrographic area within the Great Basin carbonate and alluvial aquifer system study area, appendix 2 of Heilweil, V.M., and Brooks, L.E., eds., Conceptual model of the Great Basin carbonate and alluvial aquifer system: U.S. Geological Survey Scientific Investigations Report 2010-5193, p. 143-147.

Heilweil, V.M., Sweetkind, D.S., and Susong, D.D., 2011, Introduction, chap. A of Heilweil, V.M., and Brooks, L.E., eds., Conceptual model of the Great Basin carbonate and alluvial aquifer system: U.S. Geological Survey Scientific Investigations Report 2010-5193, p. 3-14.

Hely, A.G., Mower, R.W., and Harr, C.A., 1971, Water resources of Salt Lake County, Utah: State of Utah Department of Natural Resources Technical Publication No. 31, $240 \mathrm{p}$.

Herbert, L.R., Cruff, R.W., and Holmes, W.F., 1982, Seepage study of the Sevier River and the Central Utah, McIntyre, and Leamington Canals, Juab and Millard Counties, Utah: Utah Department of Natural Resources Technical Publication No. 74, 43 p.

Herbert, L.R., and Thomas, B.K., 1992, Seepage study of the Bear River including Cutler Reservoir in Cache Valley, Utah and Idaho: Utah Department of Natural Resources Technical Publication No. 105, 18 p.

Hevesi, J.A., Flint, A.L., and Flint, L.E., 2003, Simulation of net infiltration and potential recharge using a distributed parameter watershed model of the Death Valley region, Nevada and California: U.S. Geological Survey WaterResources Investigations Report 03-4090, 91 p. 
Hill, M.C., Banta, E.R., Harbaugh, A.W., and Anderman, E.R., 2000, MODFLOW-2000, the U.S. Geological Survey modular ground-water model-User guide to the observation, sensitivity, and parameter-estimation processes and three post-processing programs: U.S. Geological Survey Open-File Report 2000-184, 209 p.

Hill, M.C., and Tiedeman, C.R., 2007, Effective groundwater model calibration: With analysis of data, sensitivities, predictions, and uncertainty: Hoboken, N.J., John Wiley and Sons, Inc., 455 p.

Holmes, W.F., 1984, Ground-water hydrology and projected effects of ground-water withdrawals in the Sevier Desert, Utah: Utah Department of Natural Resources Technical Publication No. 79, 54 p.

Hood, J.W., and Rush, F.E., 1965, Water-resources appraisal of the Snake Valley area, Utah and Nevada: Nevada Department of Conservation and Natural Resources Water Resources Reconnaissance Report 34, 43 p.

Hsieh, P.A., and Freckleton, J.R., 1993, Documentation of a computer program to simulate horizontal-flow barriers using the U.S. Geological Survey's modular three-dimensional finite-difference ground-water flow model: U.S. Geological Survey Open-File Report 92-477, 32 p.

Kariya, K.A., Roark, D.M., and Hanson, K.M., 1994, Hydrology of Cache Valley, Cache County, Utah, and adjacent part of Idaho, with emphasis on simulation of ground-water flow: Utah Department of Natural Resources Technical Publication 108, $120 \mathrm{p}$.

Malmberg, G.T., 1965, Available water supply of the Las Vegas ground-water basin, Nevada: U.S. Geological Survey Water-Supply Paper 1780, 116 p.

Malmberg, G.T., 1967, Hydrology of the valley-fill and carbonate-rock reservoirs, Pahrump Valley, Nevadaand California: U.S. Geological Survey Water-Supply Paper $1832,47 \mathrm{p}$.

Masbruch, M.D., 2011a, Current study groundwater recharge estimates for predevelopment conditions and ranges of previously reported estimates of groundwater recharge for each hydrographic area within the Great Basin carbonate and alluvial aquifer system study area, appendix 4 of Heilweil, V.M., and Brooks, L.E., eds., Conceptual model of the Great Basin carbonate and alluvial aquifer system: U.S. Geological Survey Scientific Investigations Report 2010-5193, p. $165-170$.
Masbruch, M.D., 2011b, Current study groundwater discharge estimates for predevelopment conditions and ranges of previously reported estimates of groundwater discharge for each hydrographic area within the Great Basin carbonate and alluvial aquifer system study area, appendix 5 of Heilweil, V.M., and Brooks, L.E., eds., Conceptual model of the Great Basin carbonate and alluvial aquifer system: U.S. Geological Survey Scientific Investigations Report 2010-5193, p. 171-176.

Masbruch, M.D., Heilweil, V.M., Buto, S.G., Brooks, L.E., Susong, D.D., Flint, A.L., Flint, L.E., and Gardner, P.M., 2011, Groundwater budgets, chap. D of Heilweil, V.M., and Brooks, L.E., eds., Conceptual model of the Great Basin carbonate and alluvial aquifer system: U.S. Geological Survey Scientific Investigations Report 2010-5193, p. 73-126.

Mathey, S.B., ed., 1998, National Water Information System (NWIS): U.S. Geological Survey Fact Sheet 029-98, 2 p.

Maxey, G.B., and Eakin, T.E., 1949, Ground water in White River Valley, White Pine, Nye, and Lincoln Counties, Nevada: State of Nevada Office of the State Engineer Water Resources Bulletin No. 8, 59 p.

Mehl, S.W., and Hill, M.C., 2005, MODFLOW-2005, the U.S. Geological Survey modular ground-water model - Documentation of shared node local grid refinement (LGR) and the boundary flow and head (BFH) Package, U.S. Geological Survey Techniques and Methods 6-A12, 68 p.

Meinzer, O.E., 1917, Geology and water resources of Big Smoky, Clayton, and Alkali Spring Valleys, Nevada: U.S. Geological Survey Water-Supply Paper 423, 167 p.

Moreo, M.T., Laczniak, R.J., and Stannard, D.I., 2007, Evapotranspiration rate measurements of vegetation typical of ground-water discharge areas in the Basin and Range carbonate-rock aquifer system, Nevada and Utah, September 2005-August 2006: U.S. Geological Survey Scientific Investigations Report 2007-5078, $36 \mathrm{p}$.

Morgan, D.S., and Dettinger, M.D., 1996, Ground-water conditions in Las Vegas Valley, Clark County, Nevada, Part 2, Hydrogeology and simulation of ground-water flow: U.S. Geological Survey Water-Supply Paper 2320-B, 124 p.

Mower, R.W., 1978, Hydrology of the Beaver Valley area, Beaver County, Utah, with emphasis on ground water: Utah Department of Natural Resources Technical Publication 63, $90 \mathrm{p}$.

Novak, C.E., 1985, WRD data reports preparation guide: U.S. Geological Survey Open-File Report 85-480, variously paged. 
Ogle, Dan, and St. John, Loren, 2010, Plants for saline to sodic soil conditions: U.S. Department of Agriculture, Natural Resources Conservation Service, Technical Note Plant Materials No. 9A, $10 \mathrm{p}$.

Panday, Sorab, Langevin, C.D., Niswonger, R.G., Ibaraki, Motomu, and Hughes, J.D, 2013, MODFLOW-USGS version 1: An unstructured grid version of MODFLOW for simulating groundwater flow and tightly coupled processes using a control volume finite-difference formulation: U.S. Geological Survey Techniques and Methods, book 6, chap. A45, $66 \mathrm{p}$.

Plume, R.W., 1995, Water resources and potential effects of ground-water development in Maggie, Marys, and Susie Creek basins, Elko and Eureka Counties, Nevada: U.S. Geological Survey Water-Resources Investigations Report 94-4222, $87 \mathrm{p}$.

Plume, R.W., 2009, Hydrogeologic framework and occurrence and movement of ground water in the upper Humboldt River Basin, northeastern Nevada: U.S. Geological Survey Scientific Investigations Report 2009-5014, 22 p.

Plume, R.W., and Carlton, S.M., 1988, Hydrogeology of the Great Basin region of Nevada, Utah, and adjacent states: U.S. Geological Survey Hydrologic Investigations Atlas HA 694-A, 1 sheet, scale 1:1,000,000.

Poeter, E.P., Hill, M.C., Banta, E.R., Mehl, Steffen, and Christensen, Steen, 2008, UCODE_2005 and six other computer codes for universal sensitivity analysis, calibration, and uncertainty evaluation: U.S. Geological Survey Techniques and Methods 6-A11, $283 \mathrm{p}$.

Pollock, D.W., 1994, User's guide for MODPATH/MODPATH-PLOT, version 3: A particle tracking post-processing package for MODFLOW, the U.S. Geological Survey finite-difference ground-water flow model: U.S. Geological Survey Open-File Report 94-464, variously paged.

Prudic, D.E., Harrill, J.R., and Burbey, T.J., 1995, Conceptual evaluation of regional ground-water flow in the carbonaterock province of the Great Basin, Nevada, Utah, and adjacent states: U.S. Geological Survey Professional Paper 1409-D, 102 p., http://pubs.usgs.gov/pp/1409d/report.pdf.

Reilly, T.E., 2001, System and boundary conceptualization in ground-water flow simulation: U.S. Geological Survey Techniques of Water-Resources Investigations, book 3, chap. B8, 30 p.

Reilly, T.E., Dennehy, K.F., Alley, W.M., and Cunningham, W.L., 2008, Ground-water availability in the United States: U.S. Geological Survey Circular 1323, 70 p.

Reilly, T.E., and Harbaugh, A.W., 2004, Guidelines for evaluating ground-water flow models: U.S. Geological Survey Scientific Investigations Report 2004-5038, 30 p.
Rowley, P.D., Dixon, G.L., Burns, A.G., and Collins, C.A., 2009, Geology and hydrogeology of the Snake Valley area, western Utah and eastern Nevada, in Tripp, B.T., Krahulec, Ken, and Jordan, J.L., eds., Geology and geologic resources and issues of western Utah: Utah Geological Association Publication 38, p. 251-270.

Rush, F.E., 1964, Ground-water appraisal of the Meadow Valley area, Lincoln and Clark Counties, Nevada: Nevada Department of Conservation and Natural Resources Water Resources Reconnaissance Report 27, 42 p.

Rush, F.E., 1968a, Index of hydrographic areas in Nevada: Nevada Division of Water Resources Information Report 6, $38 \mathrm{p}$.

Rush, F.E., 1968b, Water-resources appraisal of Thousand Springs Valley, Elko County, Nevada: Nevada Department of Conservation and Natural Resources Water Resources Reconnaissance Report 47, 61 p.

Rush, F.E., 1968c, Water-resources appraisal of the Lower Moapa-Lake Mead area, Clark County, Nevada: Nevada Department of Conservation and Natural Resources Water Resources Reconnaissance Report 50, 66 p.

Rush, F.E., 1968d, Water-resources appraisal of Clayton Valley-Stonewall Flat area, Nevada and California: Nevada Department of Conservation and Natural Resources Water Resources Reconnaissance Report 45, 54 p.

Rush, F.E., and Everett, D.E., 1966a, Water-resources appraisal of the Huntington Valley area, Elko and White Pine Counties, Nevada: Nevada Department of Conservation and Natural Resources Water Resources Reconnaissance Report 35, 34 p.

Rush, F.E., and Everett, D.E., 1966b, Water-resources appraisal of Little Fish Lake, Hot Creek, and Little Smoky Valleys, Nevada: Nevada Department of Conservation and Natural Resources Water Resources Reconnaissance Report 38, 38 p.

San Juan, C.A., Belcher, W.R., Laczniak, R.J., and Putnam, H.M., 2004, Hydrologic components for model development, chap. C of Belcher, W.R., ed., Death Valley regional ground-water flow system, Nevada and California-Hydrologic framework and transient ground-water flow model: U.S. Geological Survey Scientific Investigations Report 2004-5205, p. 103-136.

Southern Nevada Water Authority and U.S. Bureau of Land Management, 2008, Baseline characterization report for Clark, Lincoln, and White Pine Counties groundwater development project: Southern Nevada Water Authority, Las Vegas, Nevada, 1,156 p., accessed July 11, 2013, at http:// www.blm.gov/nv/st/en/prog/planning/groundwater projects/ snwa_groundwater_project/documents_and_maps.html 
Stephens, J.C., 1974, Hydrologic reconnaissance of the Wah Wah Valley drainage basin, Millard and Beaver Counties, Utah: Utah Department of Natural Resources Technical Publication 47, 53 p.

Stephens, J.C., 1976, Hydrologic reconnaissance of the Pine Valley drainage basin, Millard, Beaver and Iron Counties, Utah: Utah Department of Natural Resources Technical Publication 51, $38 \mathrm{p}$.

Stolp, B.J., and Brooks, L.E., 2009, Hydrology and simulation of ground-water flow in the Tooele Valley ground-water basin, Utah: U.S. Geological Survey Scientific Investigations Report 2009-5154, 86 p., 1 pl.

Strahler, A.N., 1989, Elements of physical geography, 4th ed.: New York, John Wiley and Sons, 565 p.

Sweetkind, D.S., Cederberg, J.R., Masbruch, M.D., and Buto, S.G., 2011a, Hydrogeologic framework, chap. B of Heilweil, V.M., and Brooks, L.E., eds., Conceptual model of the Great Basin carbonate and alluvial aquifer system: U.S. Geological Survey Scientific Investigations Report 2010-5193, p. 15-50.

Sweetkind, D.S., Masbruch, M.D., Heilweil, V.M., and Buto, S.G., 2011b, Groundwater flow, chap. C of Heilweil, V.M., and Brooks, L.E., eds., Conceptual model of the Great Basin carbonate and alluvial aquifer system: U.S. Geological Survey Scientific Investigations Report 2010-5193, p. $51-72$.

Taylor, G.H., and Leggette, R.M., 1949, Ground water in the Jordan Valley, Utah: U.S. Geological Survey Water-Supply Paper 1029, 357 p.

Thomas, J.M., Carlton, S.M., and Hines, L.B., 1989, Groundwater hydrology and simulated effects of development in Smith Creek Valley, a hydrologically closed basin in Lander County, Nevada: U.S. Geological Survey Professional Paper 1409-E, 57 p.

Thomas, J.M., Mason, J.L., and Crabtree, J.D., 1986, Groundwater levels in the Great Basin region of Nevada, Utah, and adjacent states: U.S. Geological Survey Hydrologic Investigations Atlas HA-694-B, 2 sheets, scale 1:1,000,000.

Thomas, J.M., Welch, A.H., and Dettinger, M.D., 1996, Geochemistry and isotope hydrology of representative aquifers in the Great Basin region of Nevada, Utah, and adjacent states: U.S. Geological Survey Professional Paper 1409-C, 100 p., 2 pl.

Tonkin, M.J., Tiedeman, C.R., Ely, D.M., and Hill, M.C., 2007, OPR-PPR, a computer program for assessing data importance to model predictions using linear statistics: U.S. Geological Survey Techniques and Methods Report TM-6E2, $115 \mathrm{p}$.
Toth, J., 1963, A theoretical analysis of groundwater flow in small drainage basins: Journal of Geophysical Research, v. 68 , no. 16 , p. $4795-4812$.

U.S. Census Bureau, 2005, Population projection program: U.S. Department of Commerce, accessed April 21, 2005, at http://www.census.gov/ipc/www/usinterimproj/.

U.S. Geological Survey, National Hydrography Dataset, accessed October 16, 2007, at http://viewer.nationalmap.gov.

U.S. Geological Survey EROS Data Center, 1999, 1 arc-second (30 meter) National Elevation Dataset: U.S. Geological Survey dataset, accessed September 15, 2008, at http://ned.usgs.gov/.

Welch, A.H., Bright, D.J, and Knochenmus, L.A., 2007, Water resources of the Basin and Range carbonate-rock aquifer system, White Pine County, Nevada, and adjacent areas in Nevada and Utah: U.S. Geological Survey Scientific Investigations Report 2007-5261, 96 p.

Weng, C., and Jackson, S.T., 1999, Late glacial and Holocene vegetation history and paleoclimate of the Kaibab Plateau, Arizona: Paleogeography, Paleoclimatology, Paleoecology, v. 153, p. 179-201.

Widarsono, B., Muladi, A., and Lemigas, I. Jaya, 2006, Permeability vertical-to-horizontal anisotropy, in Indonesian oil and gas reservoirs: A general review: Society of Petroleum Engineers First International Oil Conference and Exhibition in Mexico, 31 August-2 September 2006, Cancun, Mexico, DOI: $10.2118 / 103315-\mathrm{MS}$.

Wilberg, D.E., 1991, Hydrologic reconnaissance of the Sevier Lake area, west-central Utah: Utah Department Natural Resources Technical Publication 96, 51 p.

Wilson, J.W., 2007, Water-level surface maps of the carbonaterock and basin-fill aquifers in the Basin and Range carbonate-rock aquifer system, White Pine County, Nevada, and adjacent areas in Nevada and Utah: U.S Geological Survey Scientific Investigations Report 2007-5089, 10 p.

Winograd, I.J., and Pearson, F.J., 1976, Major carbon 14 anomaly in a regional carbonate aquifer: Possible evidence for megascale channeling, south-central Great Basin: Water Resources Research, v. 12, p. 1125-1143. 


\section{Appendix 1. Discharge Boundaries, Observations, and Error Analysis Used in the Numerical Groundwater Flow Model of the Great Basin Carbonate and Alluvial Aquifer System Study Area}

Table A1-1. Model observations of evapotranspiration of groundwater, including selected springs and rivers, in the numerical groundwater flow model, Great Basin carbonate and alluvial aquifer system study area.

[All discharge amounts in acre-feet per year unless otherwise stated. Abbreviations: HA, hydrographic area; \#, number; ETg, evapotranspiration from groundwater]

\begin{tabular}{|c|c|c|c|c|c|c|c|c|c|c|}
\hline $\begin{array}{c}\text { Model } \\
\text { observation } \\
\text { name }\end{array}$ & HA \# & Hydrographic area name & $\begin{array}{c}\text { Observed } \\
\text { ETg }^{1}\end{array}$ & $\begin{array}{c}\text { ETg } \\
\text { adjust- } \\
\text { ment }^{2}\end{array}$ & $\begin{array}{l}\text { Discharge } \\
\text { to rivers } \\
\text { included } \\
\text { in model } \\
\text { observation }\end{array}$ & $\begin{array}{c}\text { Discharge } \\
\text { to springs } \\
\text { included in } \\
\text { model } \\
\text { observation }\end{array}$ & $\begin{array}{c}\text { Total } \\
\text { discharge } \\
\text { included in } \\
\text { model } \\
\text { observation }\end{array}$ & $\begin{array}{c}\text { Model } \\
\text { observation } \\
\text { (cubic feet per } \\
\text { day) }\end{array}$ & $\begin{array}{c}\text { Area } \\
\text { included } \\
\text { in ETg area } \\
\text { (acres) }\end{array}$ & $\begin{array}{c}\text { Average } \\
\text { rate of } \\
\text { ETg } \\
\text { (feet per } \\
\text { year) }\end{array}$ \\
\hline et24clayton & 143 & Clayton Valley & 23,000 & 0 & 0 & 1,200 & 24,200 & $-2,886,111$ & 31,582 & 0.77 \\
\hline et 24 columbus & 118 & Columbus Salt Marsh Valley & 4,000 & 0 & 0 & 0 & 4,000 & $-477,043$ & 37,076 & 0.11 \\
\hline et24fishlake & 117 & Fish Lake Valley & 21,000 & 0 & 0 & 730 & 21,730 & $-2,591,537$ & 73,030 & 0.30 \\
\hline et24stcabin & 149 & Stone Cabin Valley & 1,500 & 0 & 0 & 0 & 1,500 & $-178,891$ & 5,157 & 0.29 \\
\hline et 25 grass & 138 & Grass Valley & 7,500 & 0 & 0 & 1,500 & 9,000 & $-1,073,347$ & 73,723 & 0.12 \\
\hline et26nobigsm & 137B & Northern Big Smoky Valley & 62,000 & 0 & 0 & 2,340 & 64,340 & $-7,673,239$ & 139,065 & 0.46 \\
\hline et27antelope & 151 & Antelope Valley (Eureka and Nye) & 3,200 & 0 & 0 & 0 & 3,200 & $-381,634$ & 16,663 & 0.19 \\
\hline et27diamond & 153 & Diamond Valley & 19,000 & 0 & 0 & 900 & 19,900 & $-2,373,290$ & 121,203 & 0.16 \\
\hline et27kobeh & 139 & Kobeh Valley & 12,000 & 0 & 0 & 1,560 & 13,560 & $-1,617,176$ & 46,716 & 0.29 \\
\hline et28death & 243 & Death Valley & 33,000 & 0 & 61 & 0 & 33,060 & $-3,942,884$ & 198,538 & 0.17 \\
\hline et28franklin & 230 & Amargosa Desert & 1,400 & 0 & 0 & 0 & 1,400 & $-166,965$ & 5,702 & 0.25 \\
\hline et28oasis & 228 & Oasis Valley & 4,700 & 0 & 0 & 1,280 & 5,980 & $-713,179$ & 4,739 & 1.26 \\
\hline et28penoyer & 170 & Penoyer Valley & 3,800 & 0 & 0 & 0 & 3,800 & $-453,191$ & 23,876 & 0.16 \\
\hline et28sarcobat & 146 & Sarcobatus Flat & 13,000 & 0 & 0 & 0 & 13,000 & $-1,550,390$ & 41,552 & 0.31 \\
\hline et28shoshone & 242 & Lower Amargosa Valley & 2,100 & 0 & 0 & 0 & 2,100 & $-250,448$ & 1,962 & 1.07 \\
\hline et28stewart & 162 & Pahrump Valley & 1,000 & 0 & 0 & 0 & 1,000 & $-119,261$ & 8,568 & 0.12 \\
\hline et28tecopa & 242 & Lower Amargosa Valley & 6,400 & 0 & 0 & 0 & 6,400 & $-763,269$ & 6,990 & 0.92 \\
\hline et29newark & 154 & Newark Valley & 22,000 & 0 & 0 & 1,320 & 23,320 & $-2,781,161$ & 82,872 & 0.28 \\
\hline et30fishlake & 150 & Little Fish Lake Valley & 10,000 & 0 & 0 & 0 & 10,000 & $-1,192,608$ & 8,041 & 1.24 \\
\hline et30hotcreek & 156 & Hot Creek Valley & 5,700 & 0 & 300 & 0 & 6,000 & $-715,565$ & 2,553 & 2.35 \\
\hline et $341 \mathrm{mvw}$ & 205 & Lower Meadow Valley Wash & 1,400 & 0 & 0 & 0 & 1,400 & $-166,965$ & 6,256 & 0.22 \\
\hline et34long & 175 & Long Valley & 1,000 & 0 & 0 & 0 & 1,000 & $-119,261$ & 18,283 & 0.05 \\
\hline et34panaca & 203 & Panaca Valley & 530 & 0 & 0 & 0 & 530 & $-63,208$ & 13,505 & 0.04 \\
\hline et34spring & 201 & Spring Valley & 1,000 & 0 & 0 & 0 & 1,000 & $-119,261$ & 2,262 & 0.44 \\
\hline et34vegas & 212 & Las Vegas Valley & 19,000 & 0 & 0 & 0 & 19,000 & $-2,265,955$ & 19,050 & 1.00 \\
\hline et34white & 207 & White River Valley & 34,000 & 0 & 1,500 & 0 & 35,500 & $-4,233,758$ & 172,465 & 0.21 \\
\hline et 35 goshute & 187 & Goshute Valley & 6,600 & 0 & 0 & 0 & 6,600 & $-787,121$ & 135,778 & 0.05 \\
\hline et35so_butte & $178 \mathrm{~B}$ & Butte Valley Southern Part & 12,000 & 0 & 0 & 0 & 12,000 & $-1,431,129$ & 69,356 & 0.17 \\
\hline et35steptoe & 179 & Steptoe Valley & 64,000 & 0 & 0 & 4,000 & 68,000 & $-8,109,733$ & 176,289 & 0.39 \\
\hline et36mesquite & 163 & Mesquite Valley & 2,200 & 0 & 0 & 0 & 2,200 & $-262,374$ & 16,770 & 0.13 \\
\hline et37deepck & 253 & Deep Creek Valley & 14,000 & 0 & 0 & 0 & 14,000 & $-1,669,651$ & 10,625 & 1.32 \\
\hline et37dugway & 259 & Dugway-Government Creek Valley & 1,000 & 0 & 0 & 0 & 1,000 & $-119,261$ & 13,565 & 0.07 \\
\hline et37fishspr & 258 & Fish Springs Flat & 8,000 & 0 & 0 & 0 & 8,000 & $-954,086$ & 57,929 & 0.14 \\
\hline
\end{tabular}


Table A1-1. Model observations of evapotranspiration of groundwater, including selected springs and rivers, in the numerical groundwater flow model, Great Basin carbonate and alluvial aquifer system study area.-Continued

[All discharge amounts in acre-feet per year unless otherwise stated. Abbreviations: HA, hydrographic area; \#, number; ETg, evapotranspiration from groundwater]

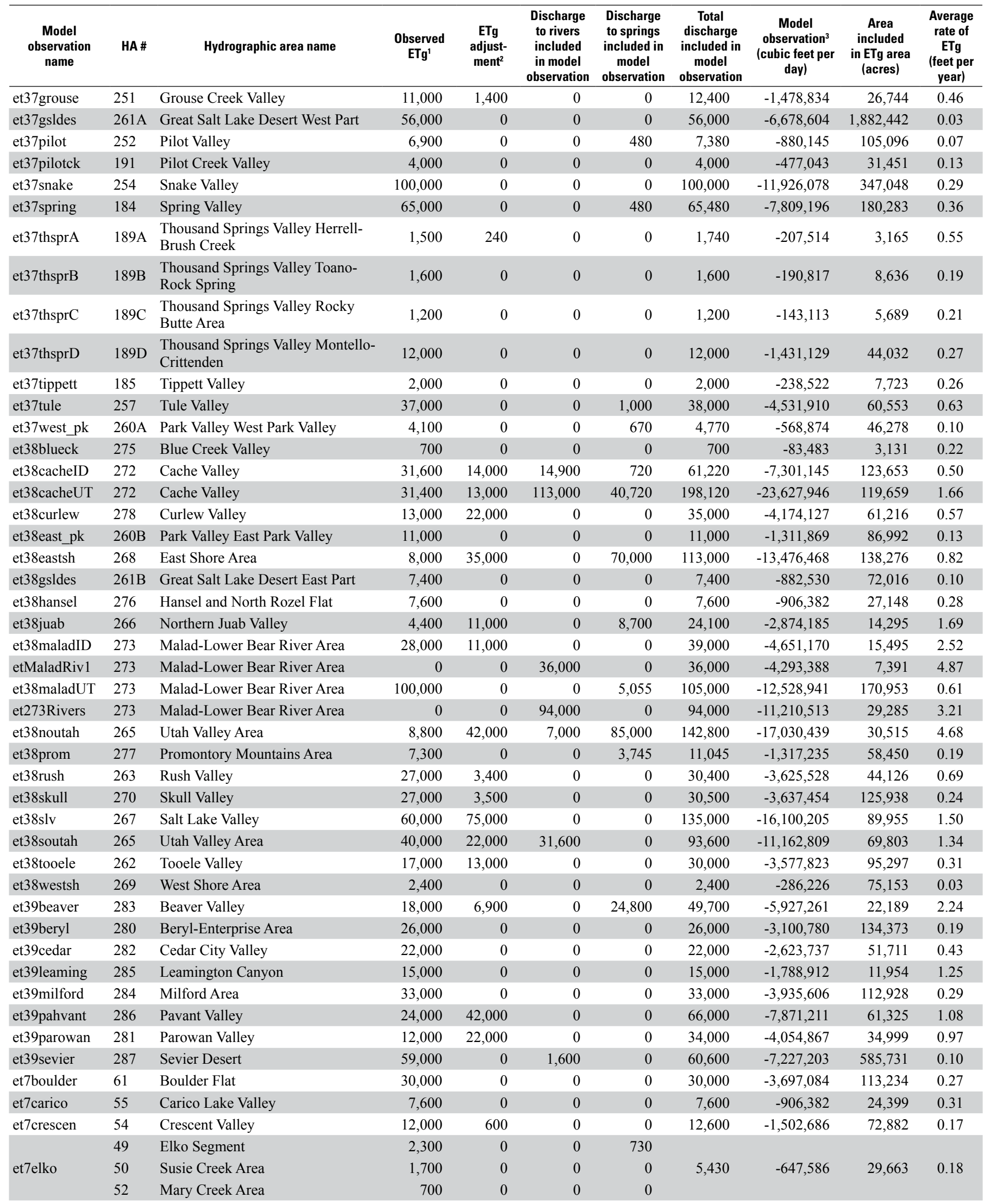


Table A1-1. Model observations of evapotranspiration of groundwater, including selected springs and rivers, in the numerical groundwater flow model, Great Basin carbonate and alluvial aquifer system study area.-Continued

[All discharge amounts in acre-feet per year unless otherwise stated. Abbreviations: HA, hydrographic area; \#, number; ETg, evapotranspiration from groundwater]

\begin{tabular}{|c|c|c|c|c|c|c|c|c|c|c|}
\hline $\begin{array}{c}\text { Model } \\
\text { observation } \\
\text { name }\end{array}$ & HA \# & Hydrographic area name & $\begin{array}{l}\text { Observed } \\
\text { ETg }^{1}\end{array}$ & $\begin{array}{c}\text { ETg } \\
\text { adjust- } \\
\text { ment }^{2}\end{array}$ & $\begin{array}{c}\text { Discharge } \\
\text { to rivers } \\
\text { included } \\
\text { in model } \\
\text { observation }\end{array}$ & $\begin{array}{c}\text { Discharge } \\
\text { to springs } \\
\text { included in } \\
\text { model } \\
\text { observation }\end{array}$ & $\begin{array}{c}\text { Total } \\
\text { discharge } \\
\text { included in } \\
\text { model } \\
\text { observation }\end{array}$ & $\begin{array}{c}\text { Model } \\
\text { observation } \\
\text { (cubic feet per } \\
\text { day) }\end{array}$ & $\begin{array}{c}\text { Area } \\
\text { included } \\
\text { in ETg area } \\
\text { (acres) }\end{array}$ & $\begin{array}{c}\text { Average } \\
\text { rate of } \\
\text { ETg } \\
\text { (feet per } \\
\text { year) } \\
\end{array}$ \\
\hline et7hunting & 47 & Huntington Valley & 10,000 & 0 & 0 & 1,080 & 11,080 & $-1,321,409$ & 49,428 & 0.22 \\
\hline et7low_reese & $\begin{array}{l}59 \\
60\end{array}$ & $\begin{array}{l}\text { Lower Reese River Valley } \\
\text { Whirlwind Valley }\end{array}$ & 26,000 & 0 & 0 & 0 & 26,000 & $-3,100,780$ & 129,296 & 0.20 \\
\hline et7maggieck & 51 & Maggie Creek Area & 9,000 & 0 & 0 & 0 & 9,000 & $-1,073,347$ & 11,981 & 0.75 \\
\hline et7pine & 53 & Pine Valley & 17,000 & 0 & 5,000 & 0 & 22,000 & $-2,623,737$ & 52,214 & 0.42 \\
\hline et7southfk & 46 & South Fork Area & 3,000 & 0 & 0 & 0 & 3,000 & $-357,782$ & 7,694 & 0.39 \\
\hline et7tenmile & 48 & Tenmile Creek Area & 4,000 & 0 & 0 & 0 & 4,000 & $-477,043$ & 29,631 & 0.13 \\
\hline et7up_reese & 56 & Upper Reese River Valley & 37,000 & 0 & 0 & 0 & 37,000 & $-4,412,649$ & 69,444 & 0.53 \\
\hline et7upHumb & $\begin{array}{l}42 \\
43 \\
44 \\
45\end{array}$ & $\begin{array}{l}\text { Marys River Area } \\
\text { Starr Valley Area } \\
\text { North Fork Area } \\
\text { Lamoille Valley }\end{array}$ & 78,000 & 0 & 0 & 1,400 & 79,400 & $-9,475,269$ & 248,630 & 0.32 \\
\hline
\end{tabular}

${ }^{1}$ Masbruch, 2011b and Heilweil and Brooks, 2011, Auxiliary 3H.

${ }^{2}$ Heilweil and Brooks, 2011, Auxiliary 30.

${ }^{3}$ Discharge is considered negative in MODFLOW. A larger discharge, therefore, is a more negative number.

Table A1-2. Spring discharge observations in the numerical groundwater flow model, Great Basin carbonate and alluvial aquifer system study area.

This table is distributed as part of this report in Microsoft ${ }^{\circledR}$ Excel 2010 format and is available for download at http://pubs.usgs.gov/sir/2014/5213/.

Table A1-3. Selected springs not simulated explicitly in the numerical groundwater flow model, Great Basin carbonate and alluvial aquifer system study area.

This table is distributed as part of this report in Microsoft $\mathrm{f}^{\circledR}$ Excel 2010 format and is available for download at http://pubs.usgs.gov/sir/2014/5213/.

Table A1-4. Observed discharge to mountain rivers in the numerical groundwater flow model, Great Basin carbonate and alluvial aquifer system study area.

This table is distributed as part of this report in Microsoft ${ }^{\circledR}$ Excel 2010 format and is available for download at http://pubs.usgs.gov/sir/2014/5213/. 


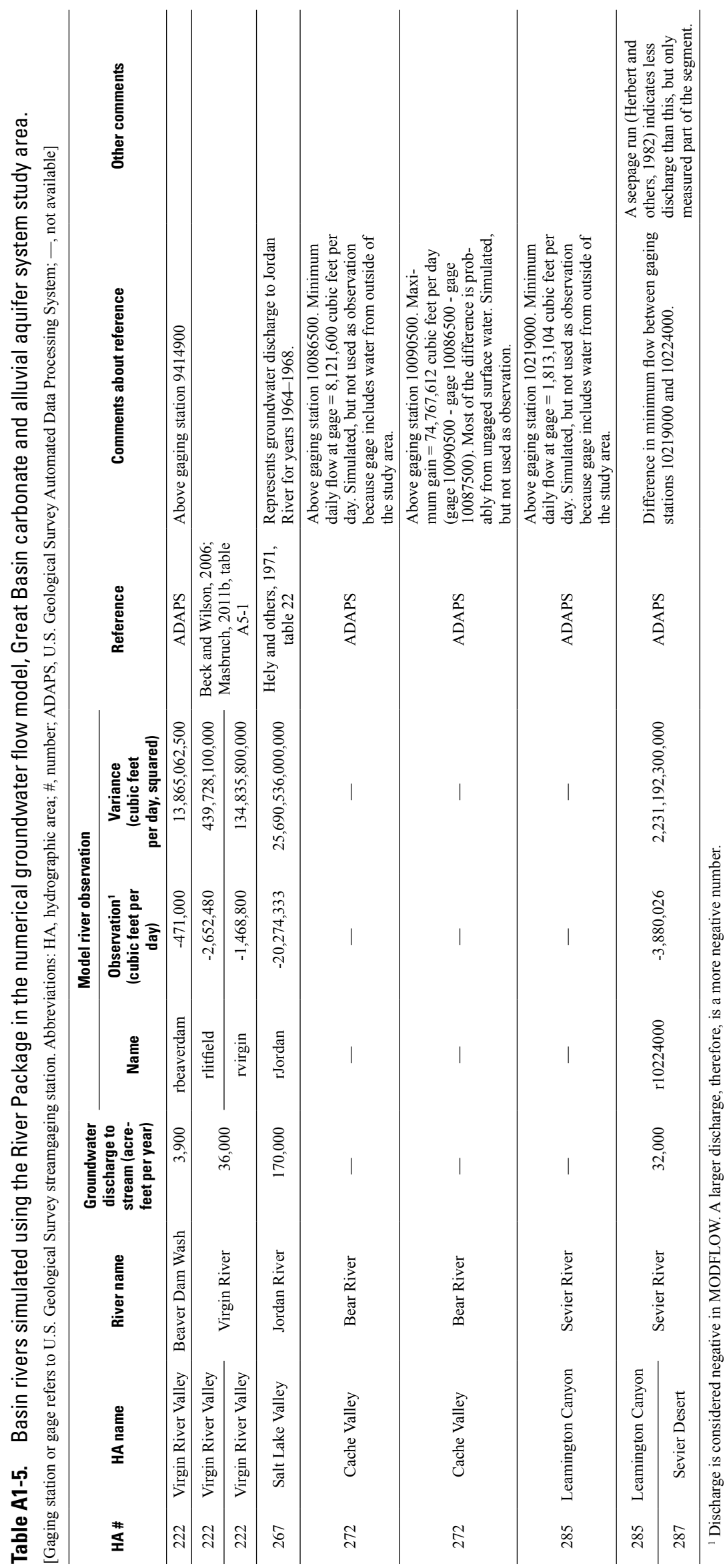


Table A1-6. Selected mountain streams not simulated in the numerical groundwater flow model, Great Basin carbonate and alluvial aquifer system study area.

[USGS gaging station number: unique identifier in U.S. Geological Survey National Water Information System. Abbreviations: HA, hydrographic area; \#, number]

\begin{tabular}{|c|c|c|c|c|}
\hline HA\# & HA name & $\begin{array}{l}\text { USGS gaging station } \\
\text { number }\end{array}$ & $\begin{array}{l}\text { Minimum dis- } \\
\text { charge (cubic feet } \\
\text { per day) }\end{array}$ & Reason for removal from simulation \\
\hline 42 & Marys River Area & 10313400 & 47,312 & Small amount of flow \\
\hline 44 & North Fork Area & 10317420 & 1,296 & Small amount of flow \\
\hline 48 & Tenmile Creek Area & 10320100 & 1,234 & Small amount of flow \\
\hline 50 & Susie Creek Area & 10321500 & 8,640 & Small amount of flow \\
\hline 51 & Maggie Creek Area & 10321860 & 6,048 & Small amount of flow \\
\hline 52 & Marys Creek Area & 10322150 & 302,404 & Gage includes spring gha52_1, which is simulated as a spring \\
\hline 56 & Upper Reese River Valley & 385323117213700 & 6,912 & Small amount of flow \\
\hline $140 \mathrm{~A}$ & Monitor Valley Northern Part & 10245925 & 39,226 & Small amount of flow \\
\hline $140 \mathrm{~B}$ & Monitor Valley Southern Part & 10245910 & 40,248 & Small amount of flow \\
\hline 149 & Stone Cabin Valley & 10249190 & 5,530 & Small amount of flow \\
\hline 156 & Hot Creek Valley & 10246930 & 5,891 & Small amount of flow \\
\hline 162 & Pahrump Valley & 10251890 & 33,350 & Small amount of flow \\
\hline $173 B$ & Railroad Valley Northern Part & 10246846 & 48,024 & Small amount of flow \\
\hline $173 \mathrm{~B}$ & Railroad Valley Northern Part & 10247200 & 17,712 & Small amount of flow \\
\hline $189 \mathrm{~A}$ & $\begin{array}{l}\text { Thousand Springs Valley } \\
\text { Herrell-Brush Creek }\end{array}$ & 10172907 & 30,960 & Small amount of flow \\
\hline 207 & White River Valley & 9415460 & 37,028 & Small amount of flow \\
\hline 264 & Cedar Valley & 10166430 & 46,286 & Small amount of flow \\
\hline 265 & Utah Valley Area & 10149000 & 449,280 & $\begin{array}{l}\text { Minimum flow at gage includes a minimum of } 420,218 \text { cubic feet per } \\
\text { day of imported water as measured at USGS gage } 9282000\end{array}$ \\
\hline 267 & Salt Lake Valley & 10171900 & 46,656 & Small amount of flow \\
\hline 273 & Malad-Lower Bear River Area & 10124000 & 4,320 & Small amount of flow \\
\hline 287 & Sevier Desert & 10224100 & 41,883 & Small amount of flow \\
\hline
\end{tabular}


Table A1-7. Selected basin rivers not simulated using the River Package in the numerical groundwater flow model, Great Basin carbonate and alluvial aquifer system study area.

[Abbreviations: HA, hydrographic area; \#, number; ETg, simulated evapotranspiration from groundwater; ADAPS, U.S. Geological Survey Automated Data Processing System]

\begin{tabular}{|c|c|c|c|c|c|c|c|}
\hline $\begin{array}{l}\text { Method used } \\
\text { to simulate dis- } \\
\text { charge in model }\end{array}$ & HA \# & HA name & River name & $\begin{array}{l}\text { Ground- } \\
\text { water } \\
\text { discharge } \\
\text { to stream, } \\
\text { in acre-feet } \\
\text { per year }\end{array}$ & Reference & Comments about reference & Other comments \\
\hline
\end{tabular}

\begin{tabular}{|c|c|c|c|c|c|c|c|}
\hline $\begin{array}{l}\text { Location simu- } \\
\text { lated with ETg }\end{array}$ & 42 & Marys River Area & Humboldt River & 0 & $\begin{array}{l}\text { Eakin and Lamke, } \\
\text { 1966, p. } 31\end{array}$ & & \\
\hline $\begin{array}{l}\text { Location simu- } \\
\text { lated with ETg }\end{array}$ & 43 & Starr Valley Area & Humboldt River & 0 & $\begin{array}{l}\text { Eakin and Lamke, } \\
\text { 1966, p. } 31\end{array}$ & & \\
\hline $\begin{array}{l}\text { Location simu- } \\
\text { lated with ETg }\end{array}$ & 44 & North Fork Area & Humboldt River & 0 & $\begin{array}{l}\text { Eakin and Lamke, } \\
\text { 1966, p. } 31\end{array}$ & & \\
\hline $\begin{array}{l}\text { Location simu- } \\
\text { lated with ETg }\end{array}$ & 45 & Lamoille Valley & Humboldt River & 0 & $\begin{array}{l}\text { Eakin and Lamke, } \\
\text { 1966, p. } 31\end{array}$ & & \\
\hline $\begin{array}{l}\text { Location simu- } \\
\text { lated using Drain } \\
\text { package }\end{array}$ & 49 & Elko Segment & $\begin{array}{l}\text { South Fork Hum- } \\
\text { boldt River }\end{array}$ & 9,000 & $\begin{array}{l}\text { Rush and Everett, } \\
1966 \mathrm{a} \text {, table } 8 \text { and } \\
\text { p. } 16\end{array}$ & $\begin{array}{l}\text { Discharge from springs between gage } \\
\text { on South Fork Humboldt River and } \\
\text { confluence of South Fork Humboldt } \\
\text { River and Humboldt River. }\end{array}$ & Included in drain gElko \\
\hline $\begin{array}{l}\text { Location simu- } \\
\text { lated using Drain } \\
\text { package }\end{array}$ & 49 & Elko Segment & Humboldt River & 6,600 & Plume, 2009, p. 5 & $\begin{array}{l}\text { Difference between measurements } \\
\text { made at gaging stations Humboldt } \\
\text { River near Elko, Humboldt River near } \\
\text { Carlin, and South Fork Humboldt } \\
\text { River near Elko. }\end{array}$ & Included in drain gElko \\
\hline Not simulated & 49 & Elko Segment & Humboldt River & 0 & $\begin{array}{l}\text { Eakin and Lamke, } \\
\text { 1966, p. } 31\end{array}$ & & \\
\hline $\begin{array}{l}\text { Location simu- } \\
\text { lated using Drain } \\
\text { package }\end{array}$ & 52 & Marys Creek Area & Humboldt River & 4,300 & Plume, 1995, p. 37 & $\begin{array}{l}\text { Gain in river includes discharge of } \\
\text { spring. }\end{array}$ & $\begin{array}{l}\text { Included in drain } \\
\text { gha52__ } 1\end{array}$ \\
\hline $\begin{array}{l}\text { Amount and lo- } \\
\text { cation simulated } \\
\text { with ETg }\end{array}$ & 53 & Pine Valley & Pine Creek & 5,000 & $\begin{array}{l}\text { Berger, 2000, table } \\
9 \text { and p. 23-24; } \\
\text { Eakin, 1961, } \\
\text { p. } 22-24\end{array}$ & $\begin{array}{l}\text { Discharge to Pine Creek in valley } \\
\text { lowland (estimated by hydrograph- } \\
\text { separation analysis). }\end{array}$ & \\
\hline $\begin{array}{l}\text { Location simu- } \\
\text { lated with ETg }\end{array}$ & 61 & Boulder Flat & Humboldt River & 0 & $\begin{array}{l}\text { Eakin and Lamke, } \\
\text { 1966, p. } 31\end{array}$ & & \\
\hline $\begin{array}{l}\text { Amount and lo- } \\
\text { cation simulated } \\
\text { with ETg }\end{array}$ & 156 & Hot Creek Valley & Hot Creek & 300 & $\begin{array}{l}\text { Rush and Everett, } \\
\text { 1966b, table } 11 \\
\text { and p. } 16\end{array}$ & & \\
\hline $\begin{array}{l}\text { Amount and lo- } \\
\text { cation simulated } \\
\text { with ETg }\end{array}$ & 207 & White River Valley & White River Wash & 1,500 & $\begin{array}{l}\text { Maxey and Eakin, } \\
1949, \text { p. } 45\end{array}$ & $\begin{array}{l}\text { Discharge to stream at south end of } \\
\text { valley. }\end{array}$ & \\
\hline $\begin{array}{l}\text { Location simu- } \\
\text { lated with ETg }\end{array}$ & 212 & Las Vegas Valley & Las Vegas Wash & 0 & $\begin{array}{l}\text { Malmberg, 1965; } \\
\text { Morgan and Det- } \\
\text { tinger, } 1996\end{array}$ & $\begin{array}{l}\text { No groundwater seepage to wash be- } \\
\text { fore urban development. After urban } \\
\text { development, wash mainly transmits } \\
\text { sewage effluent, coolant water, and } \\
\text { flood water. }\end{array}$ & \\
\hline $\begin{array}{l}\text { Amount and lo- } \\
\text { cation simulated } \\
\text { with ETg }\end{array}$ & 243 & Death Valley & Salt Creek & 61 & $\begin{array}{l}\text { ADAPS site } \\
101251100\end{array}$ & & \\
\hline
\end{tabular}

Not simulated 255 Pine Valley $\quad$ Indian, and Pine Grove Creeks

Amount and location simulated with ETg
265 Utah Valley Area Jordan River
Discharge to streams in areas of shallow water tables (short headwater 940 Stephens, 1976 reaches of streams, where intermittent or perennial groundwater sustains flow).

Cordova and 7,000 Subitzky, 1965, p. 19-22

Groundwater seepage into Jordan

River at Jordan Narrows for the year 1963.

Average annual groundwater seepCederberg and oth- Age into Jordan River for the period ers, 2009, table 4 1975-2004.
Possibly perched conditions or streams become recharge within mountain areas and represent no net change in the groundwater system.

Includes 7,000 acre-feet per year in et 38 noutah. This higher number probably represents steady-state conditions more than the numbers reported later. 
Table A1-7. Selected basin rivers not simulated using the River Package in the numerical groundwater flow model, Great Basin carbonate and alluvial aquifer system study area.-Continued

[Abbreviations: HA, hydrographic area; \#, number; ETg, simulated evapotranspiration from groundwater; ADAPS, U.S. Geological Survey Automated Data Processing System]

\begin{tabular}{|c|c|c|c|c|c|c|c|}
\hline $\begin{array}{l}\text { Method used } \\
\text { to simulate dis- } \\
\text { charge in model }\end{array}$ & HA \# & HA name & River name & $\begin{array}{l}\text { Ground- } \\
\text { water } \\
\text { discharge } \\
\text { to stream, } \\
\text { in acre-feet } \\
\text { per year }\end{array}$ & Reference & Comments about reference & Other comments \\
\hline $\begin{array}{l}\text { Amount and lo- } \\
\text { cation simulated } \\
\text { with ETg }\end{array}$ & 265 & Utah Valley Area & $\begin{array}{l}\text { Hobble Creek } \\
\text { (between (D- } \\
\text { 8-3)3dda and } \\
\text { Swenson Ditch }\end{array}$ & 8,700 & $\begin{array}{l}\text { Brooks and Stolp, } \\
1995, \text { table } 10\end{array}$ & $\begin{array}{l}1990 \text { groundwater discharge to } \\
\text { Hobble Creek from Mapleton Bench } \\
\text { groundwater system. }\end{array}$ & $\begin{array}{l}\text { Included in observation } \\
\text { et38soutah }\end{array}$ \\
\hline $\begin{array}{l}\text { Amount and lo- } \\
\text { cation simulated } \\
\text { with ETg }\end{array}$ & 265 & Utah Valley Area & $\begin{array}{l}\text { Hobble Creek } \\
\text { (downstream from } \\
\text { Swenson Ditch }\end{array}$ & 4,500 & $\begin{array}{l}\text { Brooks and Stolp, } \\
1995, \text { table } 10\end{array}$ & $\begin{array}{l}1990 \text { groundwater discharge to } \\
\text { Hobble Creek from main ground- } \\
\text { water system. }\end{array}$ & $\begin{array}{l}\text { Included in observation } \\
\text { et38soutah }\end{array}$ \\
\hline $\begin{array}{l}\text { Amount and lo- } \\
\text { cation simulated } \\
\text { with ETg }\end{array}$ & 265 & Utah Valley Area & $\begin{array}{l}\text { Spanish Fork (be- } \\
\text { tween Highway } \\
91 \text { and I-15) }\end{array}$ & 10,000 & $\begin{array}{l}\text { Brooks and Stolp, } \\
1995, \text { table } 10\end{array}$ & $\begin{array}{l}1990 \text { groundwater discharge to } \\
\text { Spanish Fork from main ground- } \\
\text { water system. }\end{array}$ & $\begin{array}{l}\text { Included in observation } \\
\text { et38soutah }\end{array}$ \\
\hline $\begin{array}{l}\text { Amount and lo- } \\
\text { cation simulated } \\
\text { with ETg }\end{array}$ & 265 & Utah Valley Area & $\begin{array}{l}\text { Spanish Fork } \\
\text { (downstream from } \\
\text { Palmyra) }\end{array}$ & 6,200 & $\begin{array}{l}\text { Brooks and Stolp, } \\
\text { 1995, table } 10\end{array}$ & $\begin{array}{l}1990 \text { groundwater discharge to } \\
\text { Spanish Fork from main ground- } \\
\text { water system. }\end{array}$ & $\begin{array}{l}\text { Included in observation } \\
\text { et38soutah }\end{array}$ \\
\hline $\begin{array}{l}\text { Amount and lo- } \\
\text { cation simulated } \\
\text { with ETg }\end{array}$ & 265 & Utah Valley Area & $\begin{array}{l}\text { Currant Creek } \\
\text { (below Goshen } \\
\text { Reservoir) }\end{array}$ & 2,200 & $\begin{array}{l}\text { Brooks and Stolp, } \\
1995, \text { table } 10\end{array}$ & $\begin{array}{l}1990 \text { groundwater discharge to } \\
\text { Currant Creek from main ground- } \\
\text { water system. }\end{array}$ & $\begin{array}{l}\text { Included in observation } \\
\text { et38soutah }\end{array}$ \\
\hline $\begin{array}{l}\text { Amount and lo- } \\
\text { cation simulated } \\
\text { with ETg }\end{array}$ & 272 & Cache Valley & Cub River & 7,200 & $\begin{array}{l}\text { Modified from } \\
\text { Kariya and others, } \\
\text { 1994, p. } 32\end{array}$ & Estimate. & $\begin{array}{l}\text { Included in observation } \\
\text { et } 38 \text { cacheID }\end{array}$ \\
\hline $\begin{array}{l}\text { Amount and lo- } \\
\text { cation simulated } \\
\text { with ETg }\end{array}$ & 272 & Cache Valley & $\begin{array}{l}\text { Bear River } \\
\text { (Riverdale, Idaho } \\
\text { to Smithfield, } \\
\text { Utah) }\end{array}$ & 17,000 & $\begin{array}{l}\text { Herbert and } \\
\text { Thomas, 1992, } \\
\text { p. } 1-3\end{array}$ & $\begin{array}{l}\text { From seepage runs; measurements } \\
\text { made on October } 22-24,1990 ; \\
\text { reported as gain of } 23.5 \text { cubic feet per } \\
\text { second. }\end{array}$ & $\begin{array}{l}\text { Included } 7,700 \text { acre-feet } \\
\text { per year in observation } \\
\text { et38cacheID and } 9,300 \\
\text { acre-feet per year in ob- } \\
\text { servation et38cacheUT }\end{array}$ \\
\hline $\begin{array}{l}\text { Amount and lo- } \\
\text { cation simulated } \\
\text { with ETg }\end{array}$ & 272 & Cache Valley & $\begin{array}{l}\text { Bear River } \\
\text { (Smithfield to } \\
\text { Wheelon, Utah } \\
\text { including Cutler } \\
\text { Reservoir) }\end{array}$ & 57,200 & $\begin{array}{l}\text { Herbert and } \\
\text { Thomas, 1992, } \\
\text { p. } 1-3\end{array}$ & $\begin{array}{l}\text { From seepage runs; measurements } \\
\text { made on November } 1-8,1990 ; \\
\text { reported as gain of } 79.0 \text { cubic feet per } \\
\text { second. }\end{array}$ & $\begin{array}{l}\text { Included in observation } \\
\text { et } 38 \text { cacheUT }\end{array}$ \\
\hline $\begin{array}{l}\text { Amount and lo- } \\
\text { cation simulated } \\
\text { with ETg }\end{array}$ & 272 & Cache Valley & Little Bear River & 2,800 & $\begin{array}{l}\text { Modified from } \\
\text { Kariya and others, } \\
\text { 1994, p. } 32\end{array}$ & Seepage run and estimate. & $\begin{array}{l}\text { Included in observation } \\
\text { et } 38 \text { cacheUT }\end{array}$ \\
\hline $\begin{array}{l}\text { Amount and lo- } \\
\text { cation simulated } \\
\text { with ETg }\end{array}$ & 272 & Cache Valley & Logan River & 2,800 & $\begin{array}{l}\text { Modified from } \\
\text { Kariya and others, } \\
\text { 1994, p. } 32\end{array}$ & Estimate. & $\begin{array}{l}\text { Included in observation } \\
\text { et } 38 \text { cacheUT }\end{array}$ \\
\hline $\begin{array}{l}\text { Amount and lo- } \\
\text { cation simulated } \\
\text { with ETg }\end{array}$ & 272 & Cache Valley & Spring Creek & 29,200 & $\begin{array}{l}\text { Bjorkland and } \\
\text { McGreevy, 1971, } \\
\text { table } 6\end{array}$ & Seepage run and estimate. & $\begin{array}{l}\text { Included in observation } \\
\text { et } 38 \text { cacheUT }\end{array}$ \\
\hline $\begin{array}{l}\text { Amount and lo- } \\
\text { cation simulated } \\
\text { with ETg }\end{array}$ & 272 & Cache Valley & Hyrum Slough & 11,400 & $\begin{array}{l}\text { Bjorkland and } \\
\text { McGreevy, 1971, } \\
\text { table } 6\end{array}$ & Seepage run and estimate. & $\begin{array}{l}\text { Included in observation } \\
\text { et } 38 \text { cacheUT }\end{array}$ \\
\hline $\begin{array}{l}\text { Amount and lo- } \\
\text { cation simulated } \\
\text { with ETg }\end{array}$ & 272 & Cache Valley & Pelican Creek & 360 & $\begin{array}{l}\text { Bjorkland and } \\
\text { McGreevy, 1971, } \\
\text { table } 6\end{array}$ & Seepage run and estimate. & $\begin{array}{l}\text { Included in observation } \\
\text { et } 38 \text { cacheUT }\end{array}$ \\
\hline $\begin{array}{l}\text { Amount and lo- } \\
\text { cation simulated } \\
\text { with ETg }\end{array}$ & 273 & $\begin{array}{l}\text { Malad-Lower Bear } \\
\text { River Area }\end{array}$ & $\begin{array}{l}\text { Bear River and } \\
\text { Malad River in } \\
\text { Utah }\end{array}$ & 130,000 & $\begin{array}{l}\text { Bjorkland and } \\
\text { McGreevy, 1974, } \\
\text { p. } 24\end{array}$ & & $\begin{array}{l}36,000 \text { acre-feet per year } \\
\text { included in observa- } \\
\text { tion etMaladRiv1 and } \\
94,000 \text { acre-feet per year } \\
\text { included in observation } \\
\text { et } 273 \text { Rivers }\end{array}$ \\
\hline $\begin{array}{l}\text { Amount and lo- } \\
\text { cation simulated } \\
\text { with ETg }\end{array}$ & 287 & Sevier Desert & Sevier River & 1,600 & Wilberg, 1991 & $\begin{array}{l}\text { Groundwater seepage measurements } \\
\text { to river made in } 1987 \text { on a } 9.5 \text {-mile } \\
\text { reach of river above Sevier Lake. }\end{array}$ & \\
\hline
\end{tabular}


Table A1-7. Selected basin rivers not simulated using the River Package in the numerical groundwater flow model, Great Basin carbonate and alluvial aquifer system study area.-Continued

[Abbreviations: HA, hydrographic area; \#, number; ETg, simulated evapotranspiration from groundwater; ADAPS, U.S. Geological Survey Automated Data Processing System]

\begin{tabular}{|c|c|c|c|c|c|c|c|}
\hline $\begin{array}{l}\text { Method used } \\
\text { to simulate dis- } \\
\text { charge in model }\end{array}$ & HA \# & HA name & River name & $\begin{array}{c}\text { Ground- } \\
\text { water } \\
\text { discharge } \\
\text { to stream, } \\
\text { in acre-feet } \\
\text { per year }\end{array}$ & Reference & Comments about reference & Other comments \\
\hline \multicolumn{8}{|c|}{ Basin rivers not simulated } \\
\hline Not simulated & 56 & $\begin{array}{l}\text { Upper Reese River } \\
\text { Valley }\end{array}$ & Reese River & $\begin{array}{r}1,000 \\
500\end{array}$ & $\begin{array}{l}\text { Berger, 2000, p. } \\
30-34 \\
\text { Eakin and others, } \\
1965 \text {, table } 5\end{array}$ & $\begin{array}{l}\text { Discharge to Reese River (estimated } \\
\text { by hydrograph-separation analysis). }\end{array}$ & $\begin{array}{l}\text { Hydrograph separa- } \\
\text { tion indicates a lot } \\
\text { less baseflow than at } \\
\text { upstream gages. This } \\
\text { river not included in } \\
\text { numerical simulation } \\
\text { because baseflow seems } \\
\text { to be generated in the } \\
\text { mountains and those } \\
\text { rivers are simulated. }\end{array}$ \\
\hline Not simulated & $189 \mathrm{~A}$ & $\begin{array}{l}\text { Thousand Springs } \\
\text { Valley Herrell- } \\
\text { Brush Creek }\end{array}$ & $\begin{array}{l}\text { Thousand } \\
\text { Springs Creek }\end{array}$ & 500 & Rush, 1968b & $\begin{array}{l}\text { Discharge to Thousand Springs Creek } \\
\text { near the boundary between HA 189A } \\
\text { and HA 189B in Thousand Springs } \\
\text { Creek. }\end{array}$ & $\begin{array}{l}\text { Records for stream } \\
\text { gages in this area show } \\
\text { little flow during } 1985 \\
\text { to } 1990 \text {. Discharge to } \\
\text { streams is assumed to } \\
\text { be included in previous } \\
\text { ETg estimates. }\end{array}$ \\
\hline Not simulated & 189B & $\begin{array}{l}\text { Thousand Springs } \\
\text { Valley Toano-Rock } \\
\text { Spring }\end{array}$ & $\begin{array}{l}\text { Thousand } \\
\text { Springs Creek }\end{array}$ & 1,000 & Rush, 1968b & $\begin{array}{l}\text { Discharge to Thousand Springs Creek } \\
\text { near the boundary between HA 189B } \\
\text { and HA 189C in Thousand Springs } \\
\text { Creek. }\end{array}$ & $\begin{array}{l}\text { Records for stream } \\
\text { gages in this area show } \\
\text { little flow during } 1985 \\
\text { to } 1990 \text {. Discharge to } \\
\text { streams is assumed to } \\
\text { be included in previous } \\
\text { ETg estimates. }\end{array}$ \\
\hline Not simulated & $189 \mathrm{D}$ & $\begin{array}{l}\text { Thousand Springs } \\
\text { Valley Montello- } \\
\text { Crittenden }\end{array}$ & $\begin{array}{l}\text { Thousand } \\
\text { Springs Creek }\end{array}$ & 100 & Rush, 1968b & $\begin{array}{l}\text { Discharge to Thousand Springs } \\
\text { Creek near the boundary between } \\
\text { HA 189D and Great Salt Lake } \\
\text { Desert (Grouse Creek Valley) in } \\
\text { Thousand Springs Creek. }\end{array}$ & \\
\hline Not simulated & 208 & Pahroc Valley & $\begin{array}{l}\text { White River } \\
\text { Wash }\end{array}$ & 0 & Eakin, 1963 & $\begin{array}{l}\text { Streamflow only occurs for short } \\
\text { intervals after high-intensity storms. }\end{array}$ & \\
\hline Not simulated & 209 & Pahranagat Valley & $\begin{array}{l}\text { White River } \\
\text { Wash }\end{array}$ & 0 & Eakin, 1963 & $\begin{array}{l}\text { Streamflow supported by spring } \\
\text { discharge or only occurs for short } \\
\text { intervals after high-intensity storms. }\end{array}$ & \\
\hline Not simulated & 215 & $\begin{array}{l}\text { Black Mountains } \\
\text { Area }\end{array}$ & Las Vegas Wash & 0 & $\begin{array}{l}\text { Rush, } 1968 \text { c, } \\
\text { p. } 19\end{array}$ & $\begin{array}{l}\text { No groundwater seepage to wash } \\
\text { reported. }\end{array}$ & \\
\hline Not simulated & 218 & California Wash & Muddy River & 0 & & & \\
\hline Not simulated & 219 & $\begin{array}{l}\text { Muddy River } \\
\text { Springs Area }\end{array}$ & Muddy River & 0 & $\begin{array}{l}\text { Rush, } 1968 b \text {, } \\
\text { p. } 19\end{array}$ & $\begin{array}{l}\text { Majority of water in Muddy River is } \\
\text { from Muddy Springs. }\end{array}$ & \\
\hline Not simulated & 220 & $\begin{array}{l}\text { Lower Moapa } \\
\text { Valley }\end{array}$ & Muddy River & 0 & & & \\
\hline Not simulated & 287 & Sevier Desert & Sevier River & 0 & Holmes, 1984 & $\begin{array}{l}\text { Through most of Sevier Desert } \\
\text { (HA 287) }\end{array}$ & \\
\hline
\end{tabular}


Table A1-8. Groundwater discharge to lakes simulated as specified-head boundaries in the numerical groundwater flow model, Great Basin carbonate and alluvial aquifer system study area.

[All discharge amounts from Heilweil and Brooks (2011, Auxiliary 3k). Abbreviations: HA, hydrographic area; \#, number]

\begin{tabular}{|c|c|c|c|c|c|c|c|}
\hline \multirow[b]{2}{*}{ HA \# } & \multirow[b]{2}{*}{ HA name } & \multirow[b]{2}{*}{ Lake name } & \multicolumn{2}{|c|}{ Groundwater discharge to lake } & \multicolumn{3}{|c|}{ Standard deviation of log values } \\
\hline & & & acre-feet per year & cubic feet per day & Observation name & $\begin{array}{c}\text { Observation }{ }^{1} \\
\text { (cubic feet per day) }\end{array}$ & $\begin{array}{c}\text { Variance } \\
\text { (cubic feet per day, } \\
\text { squared) }\end{array}$ \\
\hline $\begin{array}{l}215 \\
220\end{array}$ & $\begin{array}{l}\text { Black Mountains Area } \\
\text { Lower Moapa Valley }\end{array}$ & Lake Mead & 1,200 & 143,000 & cMead & $-143,000$ & $1,840,410,000$ \\
\hline 279 & Great Salt Lake & Great Salt Lake & 57,000 & $6,798,000$ & cgsl & $-6,798,000$ & $4,159,152,360,000$ \\
\hline 265 & Utah Valley Area & Utah Lake & 45,000 & $5,366,700$ & cutahLake & $-5,366,700$ & $2,592,132,200,100$ \\
\hline 266 & Northern Juab Valley & Mona Reservoir & 5,800 & 692,000 & cmona & $-692,000$ & $43,097,760,000$ \\
\hline 283 & Beaver Valley & Minersville Reservoir & 2,200 & 262,000 & cminers & $-262,000$ & $6,177,960,000$ \\
\hline
\end{tabular}

${ }^{1}$ Discharge is considered negative in MODFLOW. A larger discharge, therefore, is a more negative number.

Table A1-9. Supplemental data for springs used as observations in the numerical groundwater flow model, Great Basin carbonate and alluvial aquifer system study area.

This table is distributed as part of this report in Microsoft ${ }^{\circledR}$ Excel 2010 format and is available for download at http://pubs.usgs.gov/sir/2014/5213/. 


\section{Appendix 2. Water-Level Observations and Error Analysis Used in the Numerical Groundwater Flow Model of the Great Basin Carbonate and Alluvial Aquifer System Study Area}

Table A2-1. Well data, water-level observations, uncertainty, simulated values, and simulated residuals for observations of water levels in wells in the numerical groundwater flow model, Great Basin carbonate and alluvial aquifer system study area.

This table is distributed as part of this report in Microsoft ${ }^{\circledR}$ Excel 2010 format and is available for download at http://pubs.usgs.gov/sir/2014/5213/.

Table A2-2. Selected wells in which water-level data were not used as observations in the numerical groundwater flow model, Great Basin carbonate and alluvial aquifer system study area.

This table is distributed as part of this report in Microsoft ${ }^{\circledR}$ Excel 2010 format and is available for download at http://pubs.usgs.gov/sir/2014/5213/.

Water-level observations have many sources of error that should be accounted for in determining simulated weighted residuals used for error analysis, parameter sensitivity analysis, and model regression. Errors that contribute most to the uncertainty of water-level observations are associated with potential inaccuracies in the altitude and location of a well, in the measurement of water levels, and in fluctuations introduced by variations in climate or any other non-simulated transient stresses (San Juan and others, 2004, p. 128). These errors were estimated from available information and were used to quantify the uncertainty of each water-level observation.

\section{Well-Altitude Error}

Well-altitude error directly affects the calculation of the water level as referenced to the common datum. The error associated with the potential inaccuracy in well altitude was computed from the altitude accuracy code given in the U.S. Geological Survey Groundwater Site Inventory (GWSI) database, expressed as a plus or minus $( \pm$ ) range related directly to the method by which the altitude was determined. If the method indicates that altitude was determined from a map, but the accuracy was reported as less than $2 \mathrm{ft}$, the accuracy was changed to be one-half of the probable contour interval for a map of the area. If the method indicates that altitude was determined using a level, but the accuracy was reported as greater than $1 \mathrm{ft}$, the accuracy was changed to $1 \mathrm{ft}$. The range defined by the altitude accuracy is assumed to represent, with 90-percent confidence, the true well-altitude uncertainty (Hill and Tiedeman, 2007, p. 296). Assuming that the water-level observation represents the mean value and that the error is normally distributed, the uncertainty of the water-level observation, with respect to the well-altitude error, can be expressed as a standard deviation by the following equation:

$$
s d=A A C / 1.645
$$

where

$s d$ is the standard deviation, and

$A A C$ is the value of the altitude accuracy, in feet.

The value of the standard deviation for well-altitude error ranges from 0.0061 to $436 \mathrm{ft}$ (table A2-1).

\section{Well-Location Error}

Well-location error can cause a discrepancy between observed and simulated water levels. The magnitude of this discrepancy depends directly on the hydraulic gradient at the well - the steeper the gradient, the greater the discrepancy. Well-location error was calculated as the product of the distance determined from the coordinate accuracy code values given in GWSI and the hydraulic gradient estimated for a given well location. Latitude and longitude coordinate accuracy for the codes given for wells in the Great Basin carbonate and alluvial aquifer system (GBCAAS) study area range from 0.01 seconds to 1 minute. In the study area, a second represents about $100 \mathrm{ft}$. Accordingly, the largest distance accuracy that could be computed for a well in the GBCAAS model domain would be about $6,000 \mathrm{ft}$. The hydraulic gradient at a well was estimated from the slope of the water-level surface derived by interpolating water-level observations using a surface of the water-level altitude observations interpolated by using an inverse-distance weighted (IDW) calculation (Environmental Systems Research Institute, 2010). The largest gradient determined based on measured water levels was 15.3 percent and the smallest about 0.03 percent. Most of the study area has gradients ranging from about 0.06 percent to 10 percent. The range defined by the value of the coordinate accuracy code is assumed to represent, with 95-percent confidence, the true error in the water-level observation as related to well-location uncertainty (San Juan and others, 2004, p. 128). Assuming that the water-level observation represents the mean value and that the error is normally distributed, the uncertainty of the water-level observation, with respect to the well-location error, can be expressed as a standard deviation calculated by the following equation:

$$
s d=(C A C / 2) \times H G
$$

where

$s d$ is the standard deviation,

$C A C$ is the value of the coordinate accuracy, in feet, and $H G$ is the hydraulic gradient, in percent slope divided by 100 .

The standard deviation for well-location error ranges from about 0 to $64 \mathrm{ft}$ (table A2-1). 


\section{Measurement Error and Non-simulated Transient Error}

Measurement errors result from inaccuracies in the measurement of the depth to water. Measurement accuracy depends primarily on the device being used to make the measurement. Because water levels are often measured by different personnel and using different devices, it is assumed that errors are random.

Non-simulated transient errors result from water-level changes caused by stresses not simulated in the flow model, which are typically seasonal and long-term climate changes (San Juan and others, 2004, p. 130). Seasonal and annual water-level fluctuations of up to $100 \mathrm{ft}$ have been measured in wells in the GBCAAS study area (Sweetkind and others, 2011b, p. 55).

For wells with multiple water-level measurements, the variance of the measurement was calculated from the measurements. Outliers were removed before the variance calculation was made. For the approximately 600 wells that had only 1 water-level measurement, the variance of measurement error and non-simulated transient error was determined on the basis of the variance of nearby wells. This was done by creating a kriged surface of variance from the wells with multiple measurements and assigning the value of the surface to the wells with only one measurement. The standard deviation for the combined measurement and non-simulated transient error ranges from 0.01 to $164 \mathrm{ft}$ (table A2-1).

\section{Model-Discretization Errors}

Model-discretization errors result from inaccuracies in the geometric representation of hydrogeologic units (HGUs) and major structural features in the model (Faunt and others, 2004, p. 279). The magnitude of these errors is assumed to be a function of grid size, hydraulic gradient, and depth of the well open interval. The dependence on grid size occurs because larger grids result in a less accurate representation of the geometry of HGUs and of major structural features relative to well location. The dependence on hydraulic gradient occurs because inaccurate geometric representations tend to shift the location of local hydraulic gradients. The depth dependence occurs because of a decrease in the knowledge of HGUs and structures with depth. Assuming these generalizations are correct, the potential for model discretization error increases with the size of the grid, the steepness of the hydraulic gradient, and the depth of the open intervals in observation wells and model layers (Faunt and others, 2004, p. 281).

In this report, model-discretization error is assumed to be normally distributed about the water-level observation with the 95-percent confidence interval being directly proportional to the grid size and hydraulic gradient (Faunt and others, 2004, p. 281). Hydraulic gradients were calculated as explained in the "Well-Location Error" section of this report. The product of grid size and hydraulic gradient approximates the head difference across a finite-difference cell and therefore is assumed to represent the error contributed by potential inaccuracies in the geometry of HGUs and the location of major structural features (Faunt and others, 2004, p. 281).
Assuming that the water-level observation represents the mean value and that the error is normally distributed, the uncertainty of the water-level observation, with respect to the horizontal discretization error, can be expressed as a standard deviation calculated by the following equation:

$$
s d=5,280 \times H G / 1.96
$$

where

$s d$ is the standard deviation, and

$H G$ is the hydraulic gradient, in percent slope divided by 100 .

The standard deviation for horizontal discretization error ranges from about 0.05 to $257 \mathrm{ft}$ (table A2-1).

A scalar that is a function of the depth of the well open interval is used to incorporate the potential error attributed to a decrease in geologic certainty with depth (Faunt and others, 2004, p. 281). This depth scalar is calculated as 2 plus the quotient of the depth of the top of the open interval and the approximate thickness of the aquifer material in the model $(9,843 \mathrm{ft}$ as determined from water-level altitude of initial water-level observations to the top of the non-carbonate confining unit). The calculated thickness changed slightly with the deletion of some water-level observations, but the variance associated with this error is small and adjustments were not made.

Assuming that the water-level observation represents the mean value and that the error is normally distributed, the uncertainty of the water-level observation, with respect to the depth error, can be expressed as a standard deviation calculated by the following equation:

$$
s d=(2+(\operatorname{depth} / 9,843)) / 1.96
$$

where

$s d$ is the standard deviation,

depth is depth to the top of the open interval in the well, and

9,843 is the approximate thickness of the aquifer material in the model.

The standard deviation for depth error ranges from about 1.02 to $1.42 \mathrm{ft}$.

\section{Total Variance}

Based on the five potential errors, the variance of each observation was computed by the equation:

$$
\text { varh }=\text { var } 1+\text { var } 2+\text { var } 3+\text { var } 4+\operatorname{var} 5
$$

where
varh is variance of the water-level observation,
var1 is variance of the well-altitude error,
var2 is variance of the well-location error,
var3 is variance of measurement and non-simulated transient effect errors,
var4 is variance of the horizontal discretization error, and
var5 is variance of the depth error.

Computed variance of water-level observations used to calibrate the steady-state stress period range from about 1.1 to 190,000 $\mathrm{ft}^{2}$ (table A2-1). 


\section{Appendix 3. Model Results}

Table A3-1. Simulated discharge at each discharge observation in the numerical groundwater flow model, Great Basin carbonate and alluvial aquifer system study area.

This table is distributed as part of this report in Microsoft ${ }^{\circledR}$ Excel 2010 format and is available for download at http://pubs.usgs.gov/sir/2014/5213/.

The emphasis of the study and the model was regional flow. The model may provide insight and information at the hydrographic area (HA) level, but should not be the only basis for water-resource management at this scale. The simulated budgets presented for each HA are the budgets determined by the model using the calibrated parameters. The model was calibrated to water levels and groundwater discharge (see "Observations Used in Model Calibration" section of this report), not to water budgets. Uncertainty in the budgets is not presented explicitly; uncertainty in the parameters (fig. 22), however, provides an approximation of the uncertainty in the water budgets. For example, the uncertainty in recharge parameters (table A4-4) provides one measure of the uncertainty in the budgets, but uncertainty in other parameters also affects the uncertainty of the simulated budgets.

This information is provided because of public interest in water budgets for each HA, not because the model was constructed to estimate budgets at this scale. An appropriate use of this information would be by using differences in the simulated and conceptual water budgets to guide data collection in future, more detailed studies.

Table A3-2. Comparison of conceptual and simulated recharge and discharge for each hydrographic area in the numerical groundwater flow model, Great Basin carbonate and alluvial aquifer system study area.

This table is distributed as part of this report in Microsoft ${ }^{\circledR}$ Excel 2010 format and is available for download at http://pubs.usgs.gov/sir/2014/5213/.

Table A3-3. Model-predicted flow between hydrographic areas in the numerical groundwater flow model, Great Basin carbonate and alluvial aquifer system study area.

This table is distributed as part of this report in Microsoft ${ }^{\circledR}$ Excel 2010 format and is available for download at http://pubs.usgs.gov/sir/2014/5213/. 


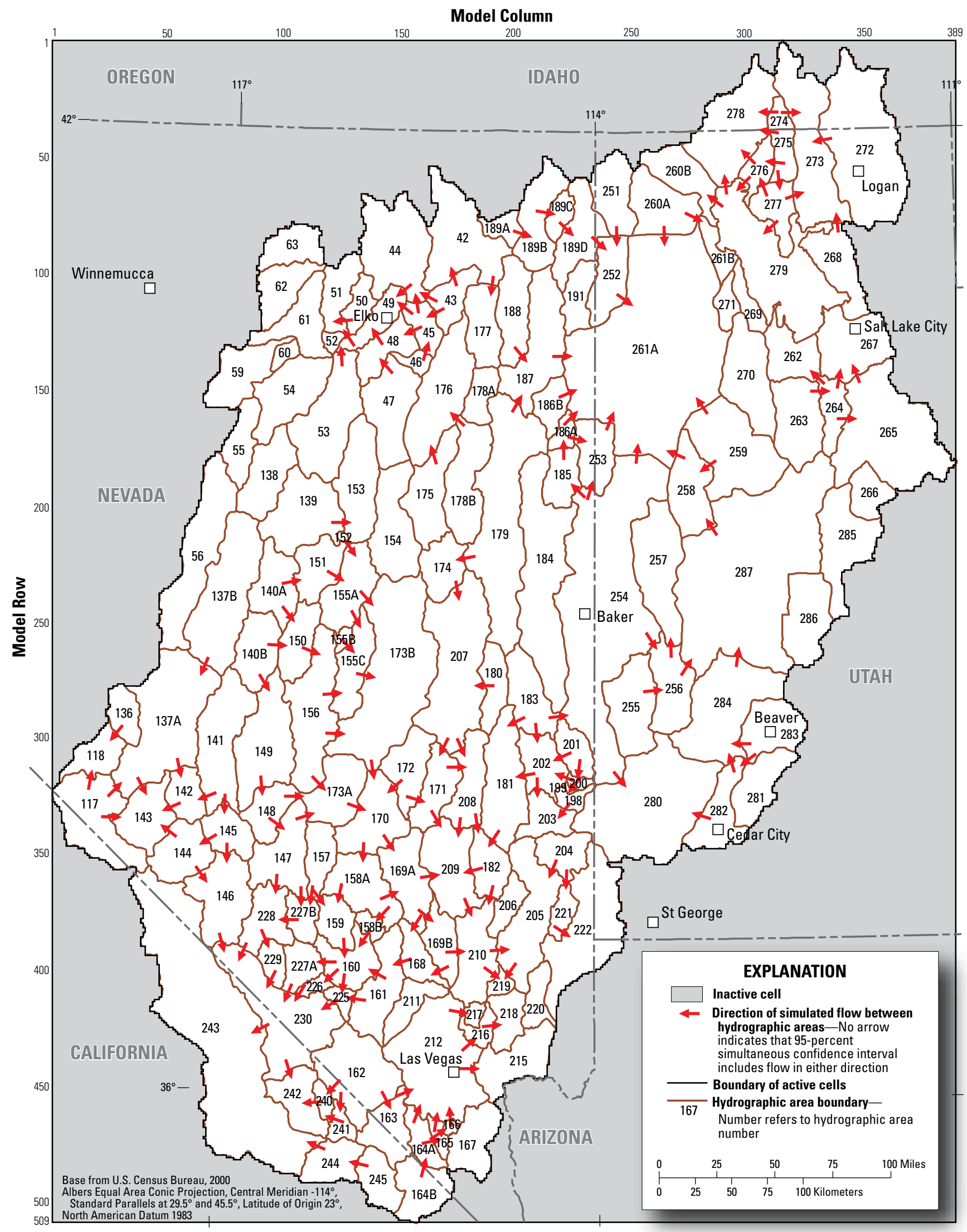

Figure A3-1. Direction of simulated subsurface flow between hydrographic areas in the numerical groundwater flow model, Great Basin carbonate and alluvial aquifer system study area. 


\section{Appendix 4. Hydrogeologic Zones, Model Parameter Description, and Model} Parameter Distribution

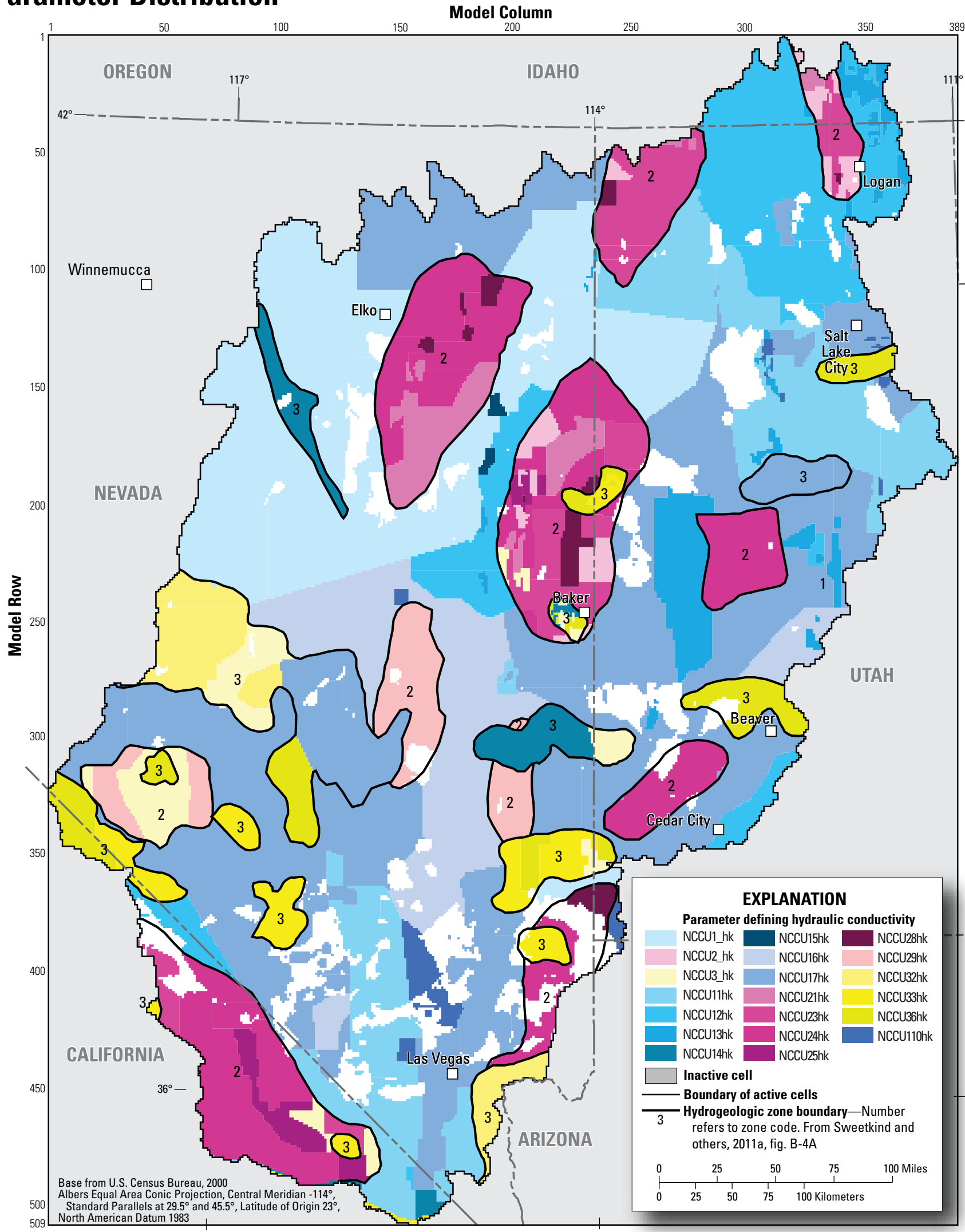

Figure A4-1. Hydrogeologic zones and distribution of model parameters defining the hydraulic conductivity of the non-carbonate confining unit (NCCU) in the numerical groundwater flow model, Great Basin carbonate and alluvial aquifer system study area. 
Table A4-1. Hydrogeologic zones, model zones, and parameter values and statistics for horizontal hydraulic conductivity of the confining units in the numerical groundwater flow model, Great Basin carbonate and alluvial aquifer system study area.

[Zone code: hydrogeologic zone from Sweetkind and others (2011a). Model zone: zone number used in MODFLOW files. Hydraulic-conductivity values in feet per day. 95-percent confidence interval: 95-percent linear confidence interval as calculated by UCODE 2005 (Poeter and others, 2008, p. 174). Standard deviation of log values: calculated by UCODE_2005 (Poeter and others, 2008). Abbreviations: HK, horizontal hydraulic conductivity; NCCU, non-carbonate confining unit; TNCCU, thrusted non-carbonate confining unit; USCU, upper siliciclastic confing unit]

\begin{tabular}{|c|c|c|c|c|c|c|c|c|}
\hline \multirow{3}{*}{$\begin{array}{l}\text { Zone } \\
\text { code }\end{array}$} & \multirow{3}{*}{$\begin{array}{c}\text { Description of zone } \\
\text { (Modified from Sweetkind and others, 2011a) } \\
\end{array}$} & \multirow{3}{*}{$\begin{array}{c}\begin{array}{c}\text { Relative } \\
\text { hydraulic } \\
\text { conductivity }\end{array} \\
\end{array}$} & \multirow{3}{*}{$\begin{array}{c}\text { Model } \\
\text { zone }\end{array}$} & \multirow{3}{*}{$\begin{array}{l}\text { Model HK } \\
\text { parameter }\end{array}$} & \multicolumn{4}{|c|}{ Model estimate of hydraulic conductivity (rounded) } \\
\hline & & & & & \multirow{2}{*}{$\begin{array}{c}\text { Parameter } \\
\text { value, in feet } \\
\text { per day }\end{array}$} & \multicolumn{2}{|c|}{ 95-percent confidence interval } & \multirow{2}{*}{$\begin{array}{c}\text { Standard } \\
\text { deviation of } \log \\
\text { values }\end{array}$} \\
\hline & & & & & & $\begin{array}{l}\text { Low value, in } \\
\text { feet per day }\end{array}$ & $\begin{array}{l}\text { High value, in } \\
\text { feet per day }\end{array}$ & \\
\hline \multirow{9}{*}{$\begin{array}{c}\mathrm{NCCU} \\
1\end{array}$} & \multirow{9}{*}{$\begin{array}{l}\text { Late Proterozoic siliciclastic rocks such as the } \\
\text { Prospect Mountain Quartzite (north), and Wood } \\
\text { Canyon Formation/Stirling Quartzite (south). Gen- } \\
\text { erally well-developed fracture network, especially } \\
\text { along bedding planes. Clay interbeds can inhibit } \\
\text { connectivity. }\end{array}$} & \multirow{9}{*}{ Moderate } & 1 & nccu1_hk & 0.0019 & 0.00074 & 0.0047 & 0.21 \\
\hline & & & 11 & nccu11hk & 0.00071 & 0.00045 & 0.0011 & 0.1 \\
\hline & & & 12 & nccu12hk & 0.0045 & 0.0029 & 0.0069 & 0.094 \\
\hline & & & 13 & nccu13hk & 0.5 & 0.35 & 0.72 & 0.082 \\
\hline & & & 14 & nccu14hk & 0.00026 & 0.00013 & 0.00052 & 0.15 \\
\hline & & & 15 & nccu15hk & 0.25 & 0.15 & 0.42 & 0.11 \\
\hline & & & 16 & nccu16hk & 0.018 & 0.0091 & 0.038 & 0.16 \\
\hline & & & 17 & nccu17hk & 0.0085 & 0.0065 & 0.011 & 0.057 \\
\hline & & & 110 & ncu110hk & 0.083 & 0.05 & 0.14 & 0.11 \\
\hline \multirow{8}{*}{$\begin{array}{c}\text { NCCU } \\
2\end{array}$} & \multirow{8}{*}{$\begin{array}{l}\text { Foliated metamorphic rocks including gneiss, } \\
\text { schist, slate associated with highly extended ter- } \\
\text { ranes and metamorphic core complexes. Foliation } \\
\text { prohibits development of well-connected fracture } \\
\text { network; matrix is impermeable. }\end{array}$} & \multirow{8}{*}{ Low } & 2 & nccu2_hk & 0.048 & 0.032 & 0.073 & 0.091 \\
\hline & & & 21 & nccu21hk & 0.2 & 0.082 & 0.48 & 0.2 \\
\hline & & & 22 & nccu3_hk & 0.11 & 0.089 & 0.15 & 0.056 \\
\hline & & & 23 & nccu23hk & 0.0053 & 0.0041 & 0.0069 & 0.057 \\
\hline & & & 24 & nccu24hk & 0.0032 & 0.0023 & 0.0043 & 0.067 \\
\hline & & & 25 & nccu25hk & 0.00015 & 0.000063 & 0.00036 & 0.19 \\
\hline & & & 28 & nccu28hk & 0.31 & 0.2 & 0.48 & 0.098 \\
\hline & & & 29 & nccu29hk & 0.0089 & 0.0059 & 0.013 & 0.092 \\
\hline \multirow{6}{*}{$\begin{array}{c}\text { NCCU } \\
3\end{array}$} & \multirow{6}{*}{$\begin{array}{l}\text { Plutonic (intrusive) rocks; inferred at depth from } \\
\text { projection of surface geology, assumption that } \\
\text { plutons underlie calderas, and interpretation of } \\
\text { magnetic and gravity data. May support well-de- } \\
\text { veloped fracture networks where at the surface or } \\
\text { within } 1 \text { kilometer of the surface; deeper intrusives } \\
\text { are probably less fractured. At depth, especially } \\
\text { beneath calderas and volcanic centers, fracture } \\
\text { permeability may be reduced by quartz veins filling } \\
\text { fractures or by clay alteration along fracture walls. }\end{array}$} & \multirow{6}{*}{$\begin{array}{c}\text { Low- } \\
\text { moderate }\end{array}$} & 3 & nccu3_hk & 0.11 & 0.089 & 0.15 & 0.056 \\
\hline & & & 32 & nccu32hk & 0.0039 & 0.0019 & 0.008 & 0.16 \\
\hline & & & 33 & nccu33hk & 0.0015 & 0.00076 & 0.0029 & 0.15 \\
\hline & & & 34 & nccu17hk & 0.0085 & 0.0065 & 0.011 & 0.057 \\
\hline & & & 35 & nccu14hk & 0.00026 & 0.00013 & 0.00052 & 0.15 \\
\hline & & & 36 & nccu36hk & 0.011 & 0.0072 & 0.017 & 0.093 \\
\hline \multirow{3}{*}{ TNCCU } & \multirow{3}{*}{ Not delineated into zones. } & \multirow{3}{*}{$\begin{array}{l}\text { Not } \\
\text { reported } \\
\text { separately } \\
\text { from NCCU }\end{array}$} & 1 & tnccu1_hk & 0.021 & 0.011 & 0.043 & 0.16 \\
\hline & & & 2 & tnccu2_hk & 0.0023 & 0.00081 & 0.0066 & 0.23 \\
\hline & & & 4 & tnccu4_hk & 0.5 & 0.25 & 0.99 & 0.15 \\
\hline \multirow{3}{*}{ USCU } & \multirow{3}{*}{ Not delineated into zones. } & \multirow{3}{*}{ Low } & 11 & uscu11hk & 0.1 & 0.028 & 0.35 & 0.28 \\
\hline & & & 13 & uscu13hk & 0.0013 & 0.00065 & 0.0025 & 0.15 \\
\hline & & & 14 & uscu14hk & 0.0036 & 0.0019 & 0.0068 & 0.14 \\
\hline
\end{tabular}




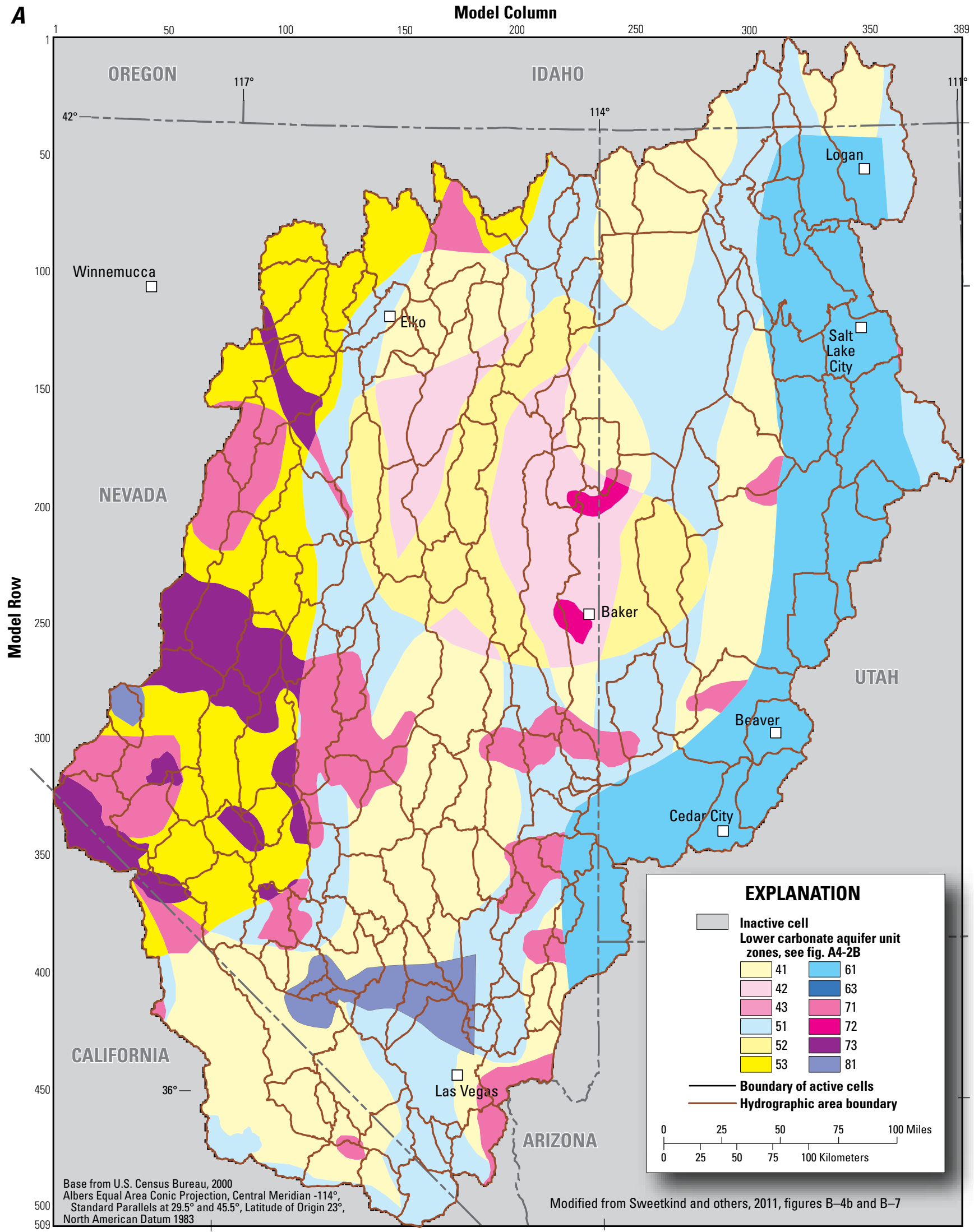

Figure A4-2. Zonation of the lower carbonate aquifer unit (LCAU) in the numerical groundwater flow model, Great Basin carbonate and alluvial aquifer system study area. $A$, Hydrogeologic zones; $B$, Relative hydraulic conductivity; and $C$, Model parameter distribution. 


\begin{tabular}{|c|c|c|c|c|c|c|}
\hline \multirow[t]{2}{*}{$\boldsymbol{B}$} & \multicolumn{6}{|c|}{$\begin{array}{c}\text { Structural zones } \\
\text { (Sweetkind and others, 2011, fig. B-7) }\end{array}$} \\
\hline & & $\begin{array}{c}4 \\
\text { Greatly extended }\end{array}$ & $\begin{array}{c}5 \\
\text { Less extended }\end{array}$ & $\begin{array}{c}6 \\
\text { Seismically active }\end{array}$ & $\begin{array}{c}7 \\
\text { Contact metamorphic }\end{array}$ & $\begin{array}{c}8 \\
\text { Zone of enhanced } \\
\text { hydraulic conductivity }\end{array}$ \\
\hline 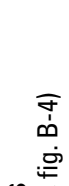 & $\begin{array}{c}1 \\
\text { Shallow-water } \\
\text { carbonates }\end{array}$ & $\begin{array}{l}41 \\
\text { Moderately low hydraulic } \\
\text { conductivity. Extension } \\
\text { may disrupt aquifer } \\
\text { continuity. }\end{array}$ & $\begin{array}{l}51 \\
\text { Moderate hydraulic } \\
\text { conductivity. This is the } \\
\text { "base case" for Great } \\
\text { Basin carbonates. }\end{array}$ & $\begin{array}{l}61 \\
\text { Highest hydraulic } \\
\text { conductivity. Both } \\
\text { lithologic and structural } \\
\text { factors enhance hydraulic } \\
\text { conductivity. }\end{array}$ & $\begin{array}{l}71 \\
\text { Low hydraulic } \\
\text { conductivity. Contact } \\
\text { metamorphism may } \\
\text { convert carbonate to } \\
\text { marble and reduce } \\
\text { hydraulic conductivity. }\end{array}$ & $\begin{array}{l}81 \\
\text { Highest hydraulic } \\
\text { conductivity. Both } \\
\text { lithology and structural } \\
\text { factors enhance hydraulic } \\
\text { conductivity. }\end{array}$ \\
\hline 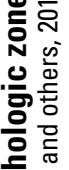 & $\begin{array}{c}2 \\
\text { Pilot Shale } \\
\text { basin }\end{array}$ & $\begin{array}{l}42 \\
\text { Low hydraulic conductivity. } \\
\text { Both lithologic and } \\
\text { structural factors reduce } \\
\text { hydraulic conductivity. }\end{array}$ & $\begin{array}{l}52 \\
\text { Moderately low hydraulic } \\
\text { conductivity. Pilot Shale } \\
\text { reduces hydraulic } \\
\text { conductivity below "base } \\
\text { case". }\end{array}$ & Does not occur. & $\begin{array}{l}72 \\
\text { Lowest hydraulic } \\
\text { conductivity. Both } \\
\text { lithology and structural } \\
\text { factors reduce hydraulic } \\
\text { conductivity. }\end{array}$ & Does not occur. \\
\hline$\sum_{0}^{\infty}$ & $\begin{array}{c}3 \\
\text { Deep-water } \\
\text { carbonates }\end{array}$ & $\begin{array}{l}43 \\
\text { Low hydraulic conductivity. } \\
\text { Both lithologic and } \\
\text { structural factors reduce } \\
\text { hydraulic conductivity. }\end{array}$ & $\begin{array}{l}53 \\
\text { Moderately low hydraulic } \\
\text { conductivity. } \\
\text { Thin-bedded, silty } \\
\text { carbonate reduces } \\
\text { hydraulic conductivity } \\
\text { below "base case". }\end{array}$ & $\begin{array}{l}63 \\
\text { Very minor in far west } \\
\text { part of area. Moderate } \\
\text { hydraulic conductivity. }\end{array}$ & $\begin{array}{l}73 \\
\text { Lowest hydraulic } \\
\text { conductivity. Both } \\
\text { lithology and structural } \\
\text { factors reduce hydraulic } \\
\text { conductivity. }\end{array}$ & Does not occur. \\
\hline
\end{tabular}

Figure A4-2. Zonation of the lower carbonate aquifer unit (LCAU) in the numerical groundwater flow model, Great Basin carbonate and alluvial aquifer system study area. $A$, Hydrogeologic zones; $B$, Relative hydraulic conductivity; and $C$, Model parameter distribution.Continued 


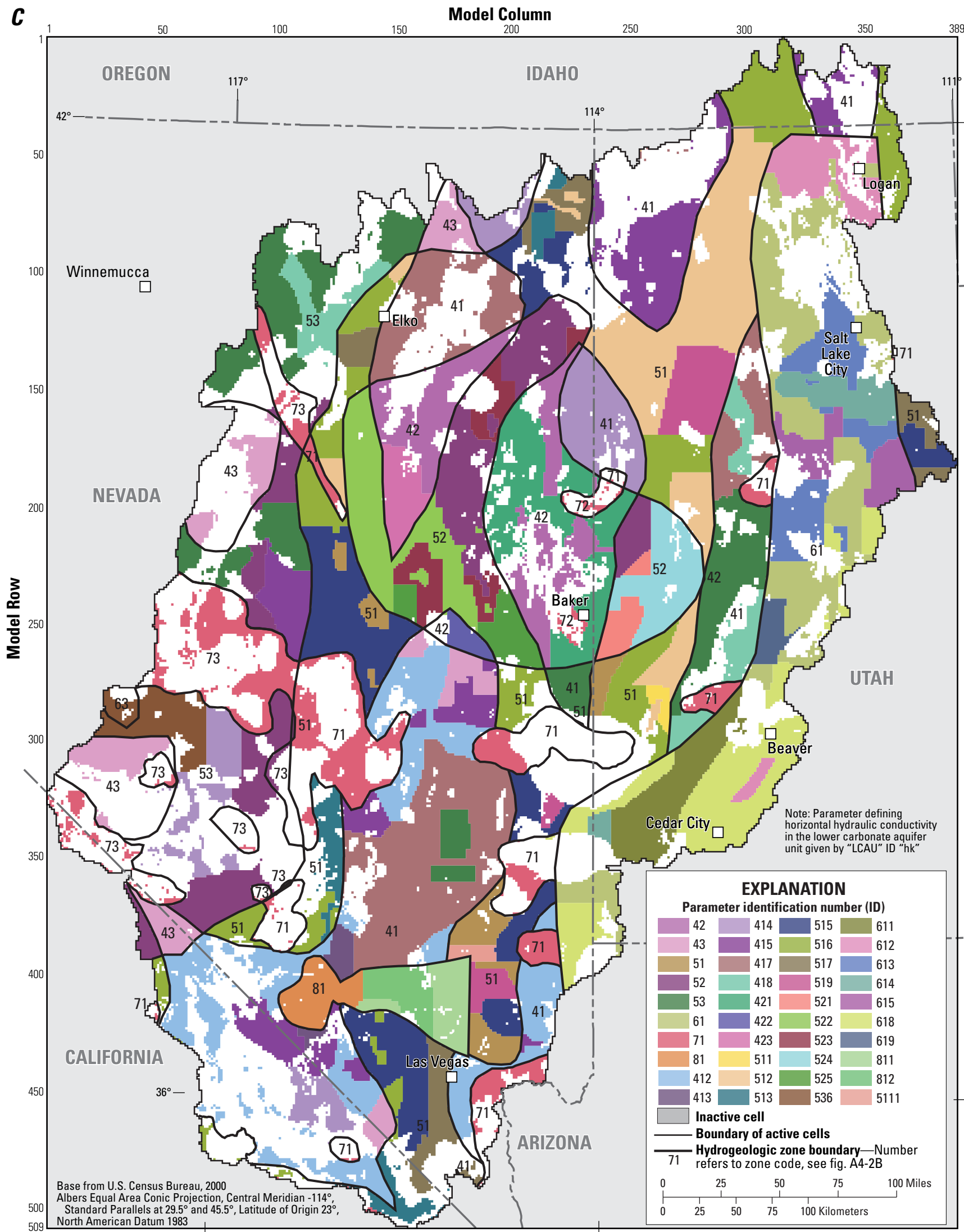

Figure A4-2. Zonation of the lower carbonate aquifer unit (LCAU) in the numerical groundwater flow model, Great Basin carbonate and alluvial aquifer system study area. $A$, Hydrogeologic zones; $B$, Relative hydraulic conductivity; and $C$, Model parameter distribution.Continued 
Table A4-2. Hydrogeologic zones, model zones, and parameter values and statistics for horizontal hydraulic conductivity of the carbonate aquifer units in the numerical groundwater flow model, Great Basin carbonate and alluvial aquifer system study area.

[Zone code: hydrogeologic zone from figure A4-2 and Sweetkind and others (2011a). Model zone: zone number used in MODFLOW files. 95-percent confidence interval: 95-percent linear confidence interval as calculated by UCODE_2005 (Poeter and others, 2008, p. 174). Standard deviation of log values: calculated by UCODE_2005 (Poeter and others, 2008). Abbreviations: HK, horizontal hydraulic conductivity; LCAU, lower carbonate aquifer unit; TLCAU, thrusted lower carbonate aquifer unit; UCAU, upper carbonate aquifer unit]

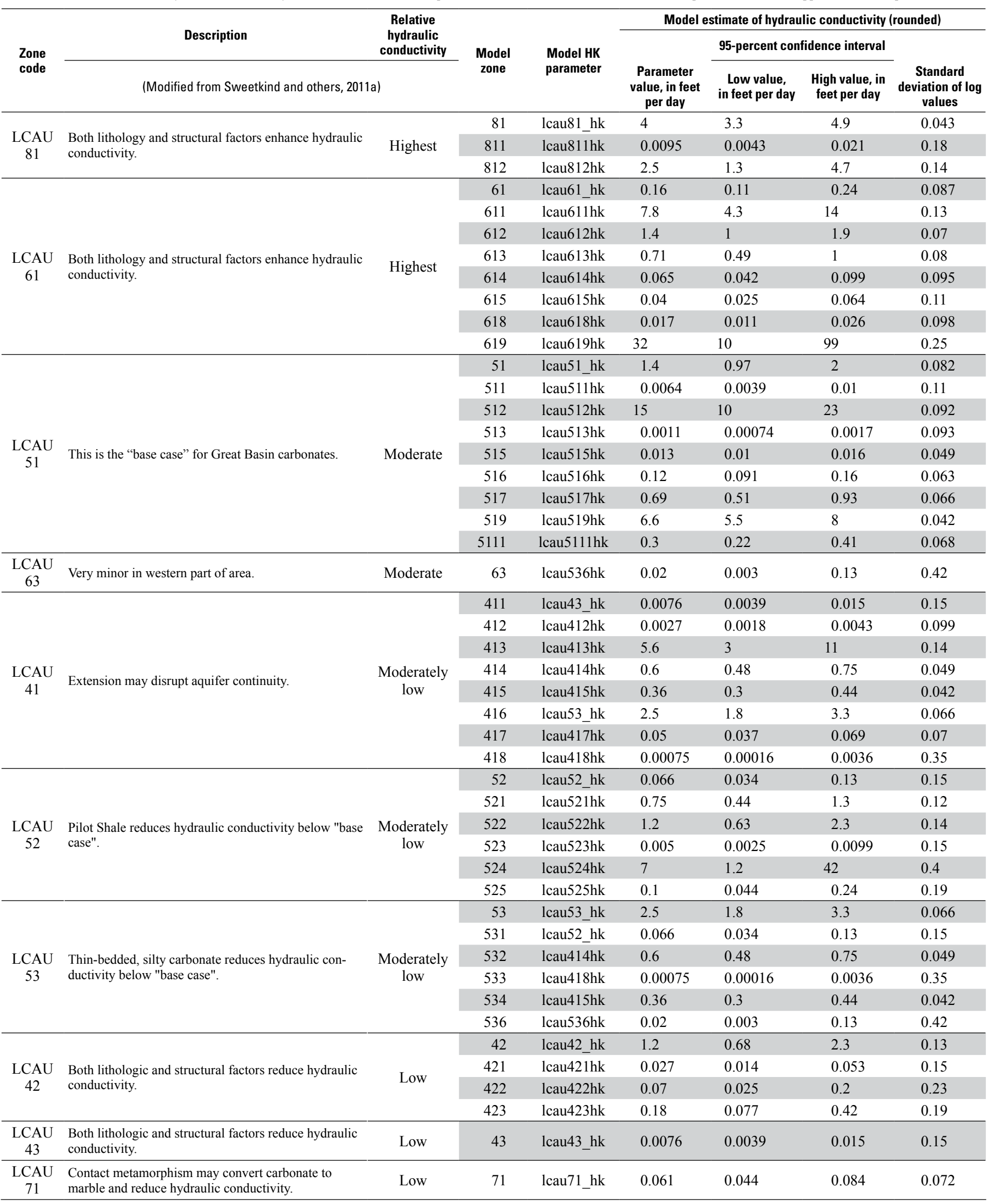


Table A4-2. Hydrogeologic zones, model zones, and parameter values and statistics for horizontal hydraulic conductivity of the carbonate aquifer units in the numerical groundwater flow model, Great Basin carbonate and alluvial aquifer system study area. - Continued

[Zone code: hydrogeologic zone from figure A4-2 and Sweetkind and others (2011a). Model zone: zone number used in MODFLOW files. 95-percent confidence interval: 95-percent linear confidence interval as calculated by UCODE_2005 (Poeter and others, 2008, p. 174). Standard deviation of log values: calculated by UCODE_2005 (Poeter and others, 2008). Abbreviations: HK, horizontal hydraulic conductivity; LCAU, lower carbonate aquifer unit; TLCAU, thrusted lower carbonate aquifer unit; UCAU, upper carbonate aquifer unit]

\begin{tabular}{|c|c|c|c|c|c|c|c|c|}
\hline \multirow{3}{*}{$\begin{array}{l}\text { Zone } \\
\text { code }\end{array}$} & \multirow{2}{*}{ Description } & \multirow{3}{*}{$\begin{array}{c}\text { Relative } \\
\text { hydraulic } \\
\text { conductivity }\end{array}$} & \multirow{3}{*}{$\begin{array}{c}\text { Model } \\
\text { zone }\end{array}$} & \multirow{3}{*}{$\begin{array}{l}\text { Model HK } \\
\text { parameter }\end{array}$} & \multicolumn{4}{|c|}{ Model estimate of hydraulic conductivity (rounded) } \\
\hline & & & & & \multirow[b]{2}{*}{$\begin{array}{c}\text { Parameter } \\
\text { value, in feet } \\
\text { per day }\end{array}$} & \multicolumn{2}{|c|}{ 95-percent confidence interval } & \multirow[b]{2}{*}{$\begin{array}{c}\text { Standard } \\
\text { deviation of log } \\
\text { values }\end{array}$} \\
\hline & (Modified from Sweetkind and others, 2011 & & & & & $\begin{array}{l}\text { Low value, } \\
\text { in feet per day }\end{array}$ & $\begin{array}{l}\text { High value, in } \\
\text { feet per day }\end{array}$ & \\
\hline $\begin{array}{l}\text { LCAU } \\
72 \\
\end{array}$ & $\begin{array}{l}\text { Both lithology and structural factors reduce hydraulic } \\
\text { conductivity. }\end{array}$ & Lowest & 72 & lcau71_hk & 0.061 & 0.044 & 0.084 & 0.072 \\
\hline $\begin{array}{l}\text { LCAU } \\
73\end{array}$ & $\begin{array}{l}\text { Both lithology and structural factors reduce hydraulic } \\
\text { conductivity. }\end{array}$ & Lowest & 73 & lcau71_hk & 0.061 & 0.044 & 0.084 & 0.072 \\
\hline \multirow{2}{*}{ TLCAU } & \multirow{2}{*}{ Not reported separately from LCAU } & \multirow{2}{*}{$\begin{array}{l}\text { Not reported } \\
\text { separately from } \\
\text { LCAU }\end{array}$} & 1 & tlcaul_hk & 0.0034 & 0.0016 & 0.0074 & 0.17 \\
\hline & & & 2 & tlcau2_hk & 0.05 & 0.011 & 0.22 & 0.33 \\
\hline \multirow{4}{*}{$\begin{array}{c}\text { UCAU } \\
1\end{array}$} & \multirow{4}{*}{$\begin{array}{l}\text { Fractured carbonate rocks of Pennsylvanian-Permian } \\
\text { age that were deposited in shallow water. Predomi- } \\
\text { nantly limestone. Generally well-developed fracture } \\
\text { network in thick upper Paleozoic carbonate rocks. }\end{array}$} & \multirow{4}{*}{ High } & 1 & ucaul_hk & 0.11 & 0.068 & 0.16 & 0.096 \\
\hline & & & 12 & ucau12hk & 3.63 & 2.2 & 6.1 & 0.11 \\
\hline & & & 13 & ucau13hk & 0.0039 & 0.00033 & 0.045 & 0.54 \\
\hline & & & 14 & ucau14hk & 0.68 & 0.55 & 0.85 & 0.048 \\
\hline \multirow{2}{*}{$\begin{array}{l}\text { UCAU } \\
2\end{array}$} & \multirow{2}{*}{$\begin{array}{l}\text { Very thick silty carbonate rocks deposited in the } \\
\text { Oquirrh Basin during Pennsylvanian time. Gener- } \\
\text { ally well-developed fracture network in thick upper } \\
\text { Paleozoic carbonate rocks. Generally more silty than } \\
\text { the shallow-water carbonates of zone 1; may reduce } \\
\text { permeability somewhat. }\end{array}$} & \multirow{2}{*}{$\begin{array}{l}\text { Moderate to } \\
\text { high }\end{array}$} & 2 & ucau2_hk & 2.1 & 0.88 & 4.8 & 0.19 \\
\hline & & & 21 & ucau1_hk & 0.11 & 0.068 & 0.16 & 0.096 \\
\hline \multirow{2}{*}{$\begin{array}{l}\text { UCAU } \\
3\end{array}$} & \multirow{2}{*}{$\begin{array}{l}\text { Continental siliciclastic rocks and other upper Pa- } \\
\text { leozoic and Mesozoic rocks of the Colorado Plateau. } \\
\text { Section is much thinner than in zones } 1 \text { and } 2 \text { and } \\
\text { contains Triassic siliciclastic rocks, such as Chinle and } \\
\text { Moenkopi Formations, that are shaly. }\end{array}$} & \multirow{2}{*}{ Moderate } & 3 & ucaul_hk & 0.11 & 0.068 & 0.16 & 0.096 \\
\hline & & & 31 & ucau31hk & 0.0005 & 0.00000048 & 0.52 & 1.5 \\
\hline $\begin{array}{l}\text { UCAU } \\
\quad 4\end{array}$ & $\begin{array}{l}\text { Carbonate rocks deposited in deep water, generally } \\
\text { thin-bedded, shaly Pennsylvanian-Permian rocks. } \\
\text { Thin bedding and fine-grained interbeds may preclude } \\
\text { development of good fracture network and reduce } \\
\text { overall permeability. }\end{array}$ & $\begin{array}{l}\text { Low to } \\
\text { moderate }\end{array}$ & 4 & ucau1_hk & 0.11 & 0.068 & 0.16 & 0.096 \\
\hline $\begin{array}{l}\text { UCAU } \\
5\end{array}$ & $\begin{array}{l}\text { Prevolcanic Cenozoic rocks of the Death Valley } \\
\text { region. Zone created for compatibility with the Death } \\
\text { Valley three-dimensional hydrogeologic framework. }\end{array}$ & $\begin{array}{l}\text { Low to } \\
\text { moderate }\end{array}$ & 5 & ucau5_hk & 0.38 & 0.24 & 0.59 & 0.099 \\
\hline
\end{tabular}




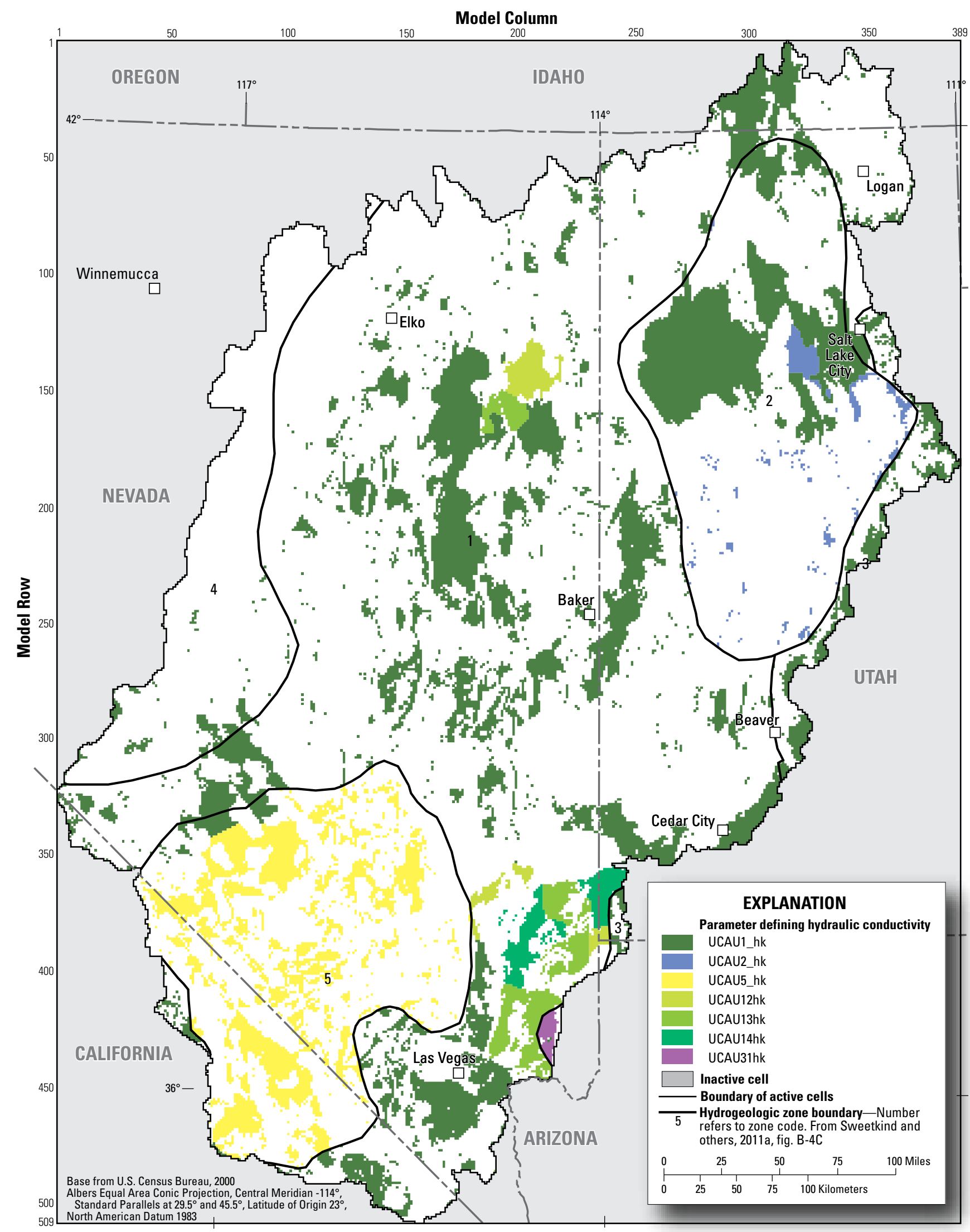

Figure A4-3. Hydrogeologic zones and distribution of model parameters defining the hydraulic conductivity of the upper carbonate aquifer unit (UCAU) in the numerical groundwater flow model, Great Basin carbonate and alluvial aquifer system study area. 
Table A4-3. Hydrogeologic zones, model zones, and parameter values and statistics for horizontal hydraulic conductivity of the volcanic and basin fill units in the numerical groundwater flow model, Great Basin carbonate and alluvial aquifer system study area.

[Zone code: hydrogeologic zone from Sweetkind and others, 2011. Model zone: zone number used in MODFLOW files. 95-percent confidence interval: 95-percent linear confidence interval as calculated by UCODE_2005 (Poeter and others, 2008). Standard deviation of log values: calculated by UCODE_2005 (Poeter and others, 2008). Abbreviations: HK, horizontal hydraulic conductivity; VU, volcanic unit; LBFAU, lower basin-fill aquifer unit; UBFAU, upper basin-fill aquifer unit; —, not applicable]

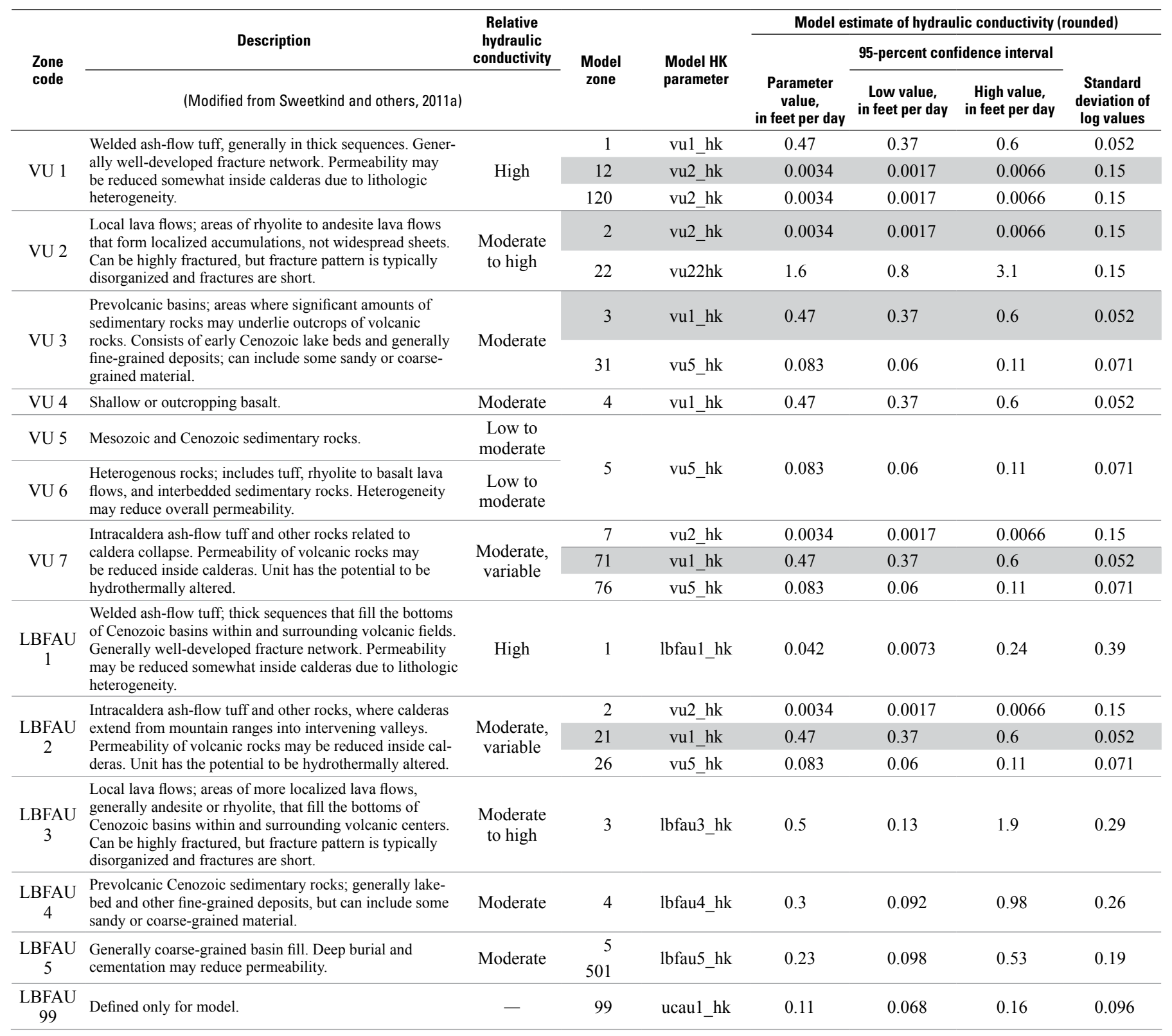


Table A4-3. Hydrogeologic zones, model zones, and parameter values and statistics for horizontal hydraulic conductivity of the volcanic and basin fill units in the numerical groundwater flow model, Great Basin carbonate and alluvial aquifer system study area.-Continued

[Zone code: hydrogeologic zone from Sweetkind and others, 2011. Model zone: zone number used in MODFLOW files. 95-percent confidence interval: 95-percent linear confidence interval as calculated by UCODE_2005 (Poeter and others, 2008). Standard deviation of log values: calculated by UCODE_2005 (Poeter and others, 2008). Abbreviations: HK, horizontal hydraulic conductivity; VU, volcanic unit; LBFAU, lower basin-fill aquifer unit; UBFAU, upper basin-fill aquifer unit; -, not applicable ]

\begin{tabular}{|c|c|c|c|c|c|c|c|c|}
\hline \multirow{3}{*}{$\begin{array}{l}\text { Zone } \\
\text { code }\end{array}$} & \multirow[b]{3}{*}{ (Modified from Sweetkind and others, 2011a) } & \multirow{3}{*}{$\begin{array}{c}\text { Relative } \\
\text { hydraulic } \\
\text { conductivity }\end{array}$} & \multirow{3}{*}{$\begin{array}{c}\text { Model } \\
\text { zone }\end{array}$} & \multirow{3}{*}{$\begin{array}{l}\text { Model HK } \\
\text { parameter }\end{array}$} & \multicolumn{4}{|c|}{ Model estimate of hydraulic conductivity (rounded) } \\
\hline & & & & & \multirow[b]{2}{*}{$\begin{array}{l}\text { Parameter } \\
\text { value, } \\
\text { in feet per day }\end{array}$} & \multicolumn{2}{|c|}{ 95-percent confidence interval } & \multirow[b]{2}{*}{$\begin{array}{c}\text { Standard } \\
\text { deviation of } \\
\text { log values }\end{array}$} \\
\hline & & & & & & $\begin{array}{l}\text { Low value, } \\
\text { in feet per day }\end{array}$ & $\begin{array}{l}\text { High value, } \\
\text { in feet per day }\end{array}$ & \\
\hline \multirow{4}{*}{$\begin{array}{l}\text { UBFAU } \\
\quad 1\end{array}$} & \multirow{4}{*}{$\begin{array}{l}\text { Near-surface basalt flows, mostly thin flows overlying } \\
\text { or within coarse-grained basin fill. Basalts can have high } \\
\text { fracture permeability and permeable zones at contacts } \\
\text { between flows. Local alteration may reduce permeability. }\end{array}$} & \multirow{4}{*}{ Moderate } & 1 & ubfaul_hk & 4.8 & 2.6 & 9.1 & 0.14 \\
\hline & & & 11 & ubfau31hk & 8 & 6.6 & 9.8 & 0.044 \\
\hline & & & $\begin{array}{r}12 \\
122\end{array}$ & ubfau12hk & 0.12 & 0.05 & 0.29 & 0.19 \\
\hline & & & 13 & ubfau13hk & 120 & 50 & 270 & 0.19 \\
\hline \multirow[b]{2}{*}{$\begin{array}{l}\text { UBFAU } \\
2\end{array}$} & \multirow[b]{2}{*}{$\begin{array}{l}\text { Prevolcanic and synvolcanic sediments. Early Cenozoic } \\
\text { lake beds and generally fine-grained deposits. }\end{array}$} & \multirow[b]{2}{*}{$\begin{array}{l}\text { Moderate } \\
\text { to low }\end{array}$} & 2 & ubfau2_hk & 0.81 & 0.5 & 1.3 & 0.11 \\
\hline & & & $\begin{array}{r}23 \\
232\end{array}$ & ubfau $23 \mathrm{hk}$ & 0.19 & 0.035 & 1 & 0.37 \\
\hline \multirow{5}{*}{$\begin{array}{l}\text { UBFAU } \\
3\end{array}$} & \multirow{5}{*}{$\begin{array}{l}\text { Areas of Pleistocene lakes and modern playas consisting } \\
\text { of fine-grained surficial sediments. }\end{array}$} & \multirow{5}{*}{$\begin{array}{l}\text { Moderate } \\
\text { to low }\end{array}$} & 3 & ubfau3_hk & 3.4 & 2.6 & 4.3 & 0.056 \\
\hline & & & $\begin{array}{r}31 \\
312\end{array}$ & ubfau31hk & 8 & 6.6 & 9.8 & 0.044 \\
\hline & & & $\begin{array}{r}34 \\
342\end{array}$ & ubfau34hk & 1 & 0.69 & 1.4 & 0.081 \\
\hline & & & $\begin{array}{r}35 \\
352\end{array}$ & ubfau35hk & 39 & 28 & 55 & 0.075 \\
\hline & & & 36 & ubfau36hk & 15 & 8.6 & 25 & 0.12 \\
\hline \multirow{7}{*}{$\begin{array}{l}\text { UBFAU } \\
\quad 4\end{array}$} & \multirow{7}{*}{$\begin{array}{l}\text { Undivided basin fill. Inferred to be late Cenozoic alluvial } \\
\text { sands and gravels. }\end{array}$} & \multirow{7}{*}{ Moderate } & 4 & ubfau4_hk & 0.39 & 0.3 & 0.5 & 0.058 \\
\hline & & & 41 & ubfau41hk & 2 & 1.6 & 2.6 & 0.052 \\
\hline & & & 42 & ubfau31hk & 8 & 6.6 & 9.8 & 0.044 \\
\hline & & & 44 & ubfau2_hk & 0.81 & 0.5 & 1.3 & 0.11 \\
\hline & & & 45 & ubfau45hk & 22 & 18 & 28 & 0.051 \\
\hline & & & $\begin{array}{r}48 \\
481\end{array}$ & ubfau48hk & 0.23 & 0.14 & 0.36 & 0.1 \\
\hline & & & 49 & ubfau13hk & 120 & 50 & 270 & 0.19 \\
\hline $\begin{array}{l}\text { UBFAU } \\
\quad 99\end{array}$ & Defined only for model. & - & 99 & ucau1_hk & 0.11 & 0.068 & 0.16 & 0.096 \\
\hline
\end{tabular}




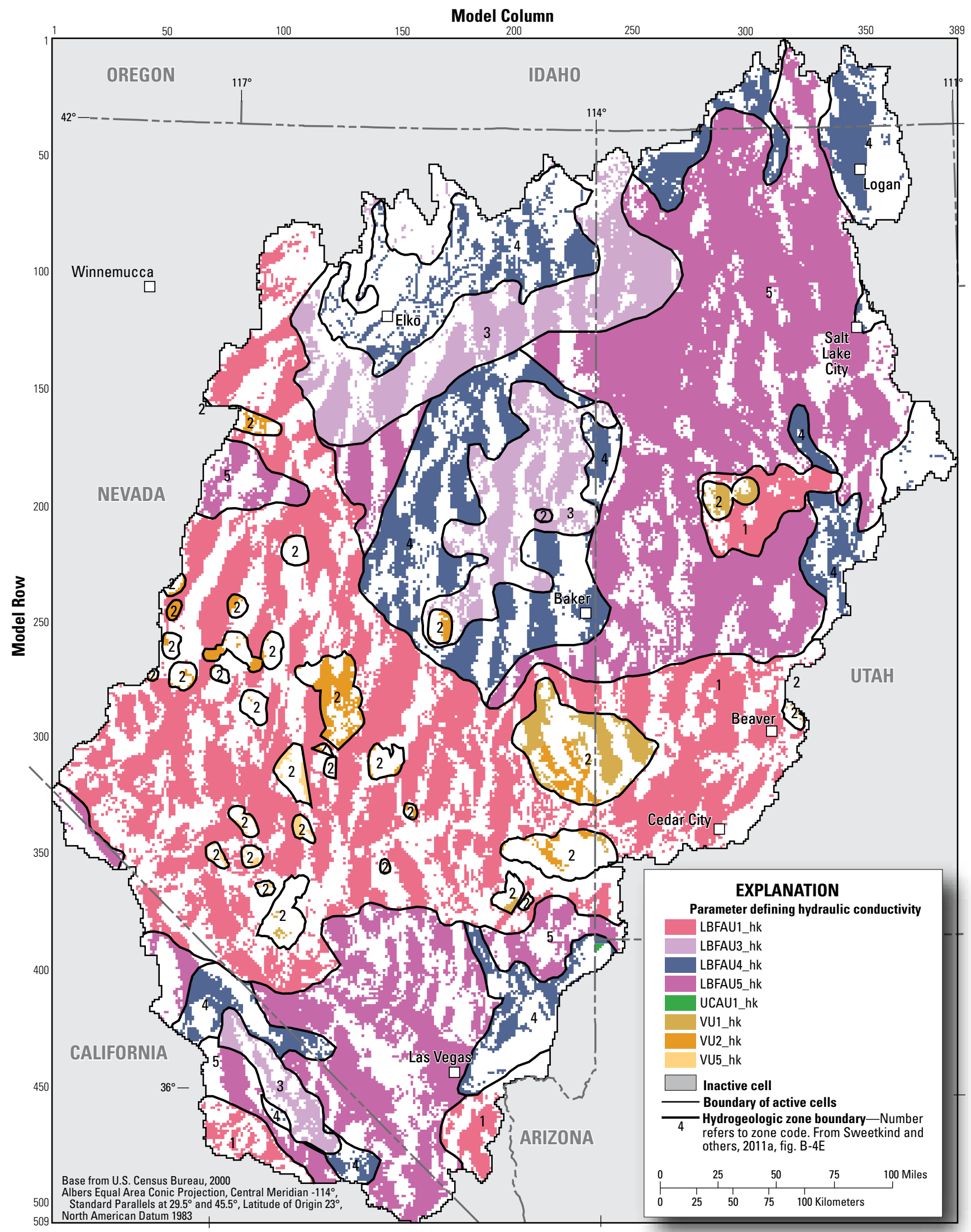

Figure A4-4. Hydrogeologic zones and distribution of model parameters defining the hydraulic conductivity of the lower basin-fill aquifer unit (LBFAU) in the numerical groundwater flow model, Great Basin carbonate and alluvial aquifer system study area. 


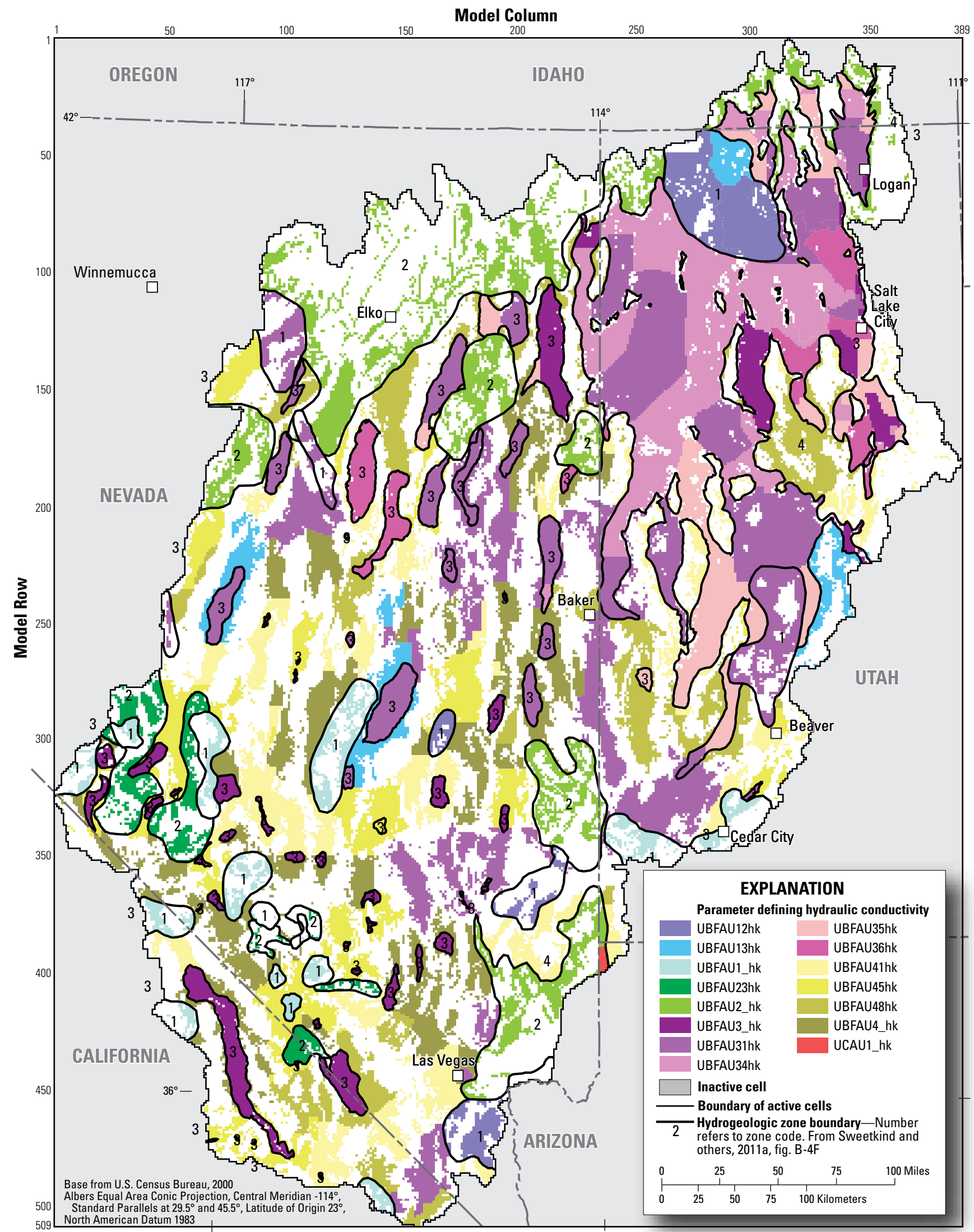

Figure A4-5. Hydrogeologic zones and distribution of model parameters defining the hydraulic conductivity of the upper basin-fill aquifer unit (UBFAU) in the numerical groundwater flow model, Great Basin carbonate and alluvial aquifer system study area. 
Table A4-4. Model zones, multiplier arrays, and parameter values and statistics for recharge and lateral flow boundaries in the numerical groundwater flow model, Great Basin carbonate and alluvial aquifer system study area.

[Parameter value: multiplier of the conceptual recharge rate defined by the model multiplier arrays. 95-percent confidence interval: 95 -percent linear confidence interval calculated by UCODE_2005 (Poeter and others, 2008, p. 174). Standard deviation: calculated by UCODE_2005 (Poeter and others, 2008). Abbreviations: HA, hydrographic area; \#, number; —, not applicable]

\begin{tabular}{|c|c|c|c|c|c|c|c|}
\hline \multirow{3}{*}{$\begin{array}{l}\text { Parameter } \\
\text { name }\end{array}$} & \multirow{3}{*}{$\begin{array}{l}\text { Model } \\
\text { recharge } \\
\text { zones }\end{array}$} & \multirow{3}{*}{ Model multiplier arrays } & \multirow{3}{*}{ Location by HA\# } & \multicolumn{4}{|c|}{ Model estimate of recharge parameter, dimensionless } \\
\hline & & & & \multirow{2}{*}{$\begin{array}{l}\text { Parameter } \\
\text { value }\end{array}$} & \multicolumn{2}{|c|}{ 95-percent confidence interval } & \multirow{2}{*}{$\begin{array}{l}\text { Standard } \\
\text { deviation }\end{array}$} \\
\hline & & & & & Low value & High value & \\
\hline $\operatorname{rch} 42$ & 42 & $\begin{array}{l}\text { rech_inplace } \\
\text { rech_runoff } \\
\text { rech_base }\end{array}$ & $42-46,50,51,176$ & 0.75 & 0.60 & 0.89 & 0.07 \\
\hline $\operatorname{rch} 48$ & 48 & $\begin{array}{l}\text { rech_inplace } \\
\text { rech_runoff } \\
\text { rech_base } \\
\text { rech_import }\end{array}$ & $44-49$ & 0.40 & 0.22 & 0.57 & 0.09 \\
\hline $\operatorname{rch} 54$ & 54 & $\begin{array}{l}\text { rech_inplace } \\
\text { rech_runoff } \\
\text { rech_base }\end{array}$ & $51-55,59-63$ & 1.38 & 0.78 & 1.99 & 0.31 \\
\hline $\operatorname{rch} 62$ & 62 & $\begin{array}{l}\text { rech_inplace } \\
\text { rech_runoff } \\
\text { rech_base }\end{array}$ & $61-63$ & 1.00 & 0.70 & 1.30 & 0.15 \\
\hline $\operatorname{rch} 117$ & 117 & $\begin{array}{l}\text { rech_inplace } \\
\text { rech_runoff } \\
\text { rech_base }\end{array}$ & $\begin{array}{l}117,144-148,162,163,226,227 \mathrm{~A}, 229,230, \\
240-245\end{array}$ & 1.10 & 0.80 & 1.40 & 0.15 \\
\hline $\operatorname{rch} 140$ & 140 & $\begin{array}{l}\text { rech_inplace } \\
\text { rech_runoff } \\
\text { rech_base }\end{array}$ & $138,139,140 \mathrm{~A}, 140 \mathrm{~B}$ & 0.70 & 0.51 & 0.90 & 0.10 \\
\hline $\operatorname{rch} 141$ & 141 & $\begin{array}{l}\text { rech_inplace } \\
\text { rech_runoff } \\
\text { rech_base }\end{array}$ & $\begin{array}{l}117,118,136,137 \mathrm{~A}, 137 \mathrm{~B}, 140 \mathrm{~B}, 141-143,149 \\
156,173 \mathrm{~B}\end{array}$ & 1.12 & 0.91 & 1.33 & 0.11 \\
\hline $\operatorname{rch} 144$ & 144 & $\begin{array}{l}\text { rech_inplace } \\
\text { rech_runoff } \\
\text { rech_base }\end{array}$ & $117,143,144,243$ & 0.60 & 0.34 & 0.86 & 0.13 \\
\hline $\operatorname{rch} 147$ & 147 & $\begin{array}{l}\text { rech_inplace } \\
\text { rech_runoff } \\
\text { rech_base }\end{array}$ & $147,157,227 \mathrm{~B}, 228$ & 0.13 & 0.02 & 0.25 & 0.06 \\
\hline $\operatorname{rch} 150$ & 150 & $\begin{array}{l}\text { rech_inplace } \\
\text { rech_runoff } \\
\text { rech_base }\end{array}$ & $56,137 \mathrm{~B}, 150,155 \mathrm{~A}, 155 \mathrm{~B}, 155 \mathrm{C}, 156,173 \mathrm{~B}, 207$ & 1.30 & 0.96 & 1.65 & 0.18 \\
\hline $\operatorname{rch} 154$ & 154 & $\begin{array}{l}\text { rech_inplace } \\
\text { rech_runoff } \\
\text { rech_base }\end{array}$ & $139,151-154,155 \mathrm{~A}, 173 \mathrm{~B}, 174$ & 0.85 & 0.62 & 1.08 & 0.12 \\
\hline $\operatorname{rch} 157$ & 157 & $\begin{array}{l}\text { rech_inplace } \\
\text { rech_runoff } \\
\text { rech_base }\end{array}$ & $147,148,157,158 \mathrm{~A}, 159,170,173 \mathrm{~A}, 227 \mathrm{~B}, 228$ & 0.37 & 0.25 & 0.50 & 0.06 \\
\hline $\operatorname{rch} 161$ & 161 & $\begin{array}{l}\text { rech_inplace } \\
\text { rech_runoff } \\
\text { rech_base }\end{array}$ & 158B, 160-163, 168, 169B, 211, 225 & 0.96 & 0.72 & 1.21 & 0.13 \\
\hline $\operatorname{rch} 172$ & 172 & $\begin{array}{l}\text { rech_inplace } \\
\text { rech_runoff } \\
\text { rech_base }\end{array}$ & 158A, 169A, 170-172, 209 & 0.44 & 0.28 & 0.59 & 0.08 \\
\hline $\operatorname{rch} 175$ & 175 & $\begin{array}{l}\text { rech_inplace } \\
\text { rech_runoff } \\
\text { rech_base }\end{array}$ & $47,174-177,178,187,188,189 \mathrm{D}, 191,252,261 \mathrm{~A}$ & 0.58 & 0.46 & 0.69 & 0.06 \\
\hline $\operatorname{rch} 179$ & 179 & $\begin{array}{l}\text { rech_inplace } \\
\text { rech_runoff } \\
\text { rech_base }\end{array}$ & $179,184,207$ & 1.08 & 0.94 & 1.23 & 0.07 \\
\hline $\operatorname{rch} 180$ & 180 & $\begin{array}{l}\text { rech_inplace } \\
\text { rech_runoff } \\
\text { rech_base }\end{array}$ & 180,183 & 1.62 & 0.87 & 2.38 & 0.39 \\
\hline
\end{tabular}


Table A4-4. Model zones, multiplier arrays, and parameter values and statistics for recharge and lateral flow boundaries in the numerical groundwater flow model, Great Basin carbonate and alluvial aquifer system study area.-Continued

[Parameter value: multiplier of the conceptual recharge rate defined by the model multiplier arrays. 95-percent confidence interval: 95 -percent linear confidence interval calculated by UCODE_2005 (Poeter and others, 2008, p. 174). Standard deviation: calculated by UCODE_2005 (Poeter and others, 2008). Abbreviations: HA, hydrographic area; \#, number; —, not applicable]

\begin{tabular}{|c|c|c|c|c|c|c|c|}
\hline \multirow{3}{*}{$\begin{array}{l}\text { Parameter } \\
\text { name }\end{array}$} & \multirow{3}{*}{$\begin{array}{l}\text { Model } \\
\text { recharge } \\
\text { zones }\end{array}$} & \multirow{3}{*}{ Model multiplier arrays } & \multirow{3}{*}{ Location by HA \# } & \multicolumn{4}{|c|}{ Model estimate of recharge parameter, dimensionless } \\
\hline & & & & \multirow{2}{*}{$\begin{array}{l}\text { Parameter } \\
\text { value }\end{array}$} & \multicolumn{2}{|c|}{ 95-percent confidence interval } & \multirow{2}{*}{$\begin{array}{l}\text { Standard } \\
\text { deviation }\end{array}$} \\
\hline & & & & & Low value & High value & \\
\hline $\operatorname{rch} 184$ & 184 & $\begin{array}{l}\text { rech_inplace } \\
\text { rech_runoff } \\
\text { rech_base }\end{array}$ & $\begin{array}{l}178 \mathrm{~A}, 179,184,185,186 \mathrm{~A}, 186 \mathrm{~B}, 253-257,261 \mathrm{~A}, \\
284,287\end{array}$ & 0.90 & 0.75 & 1.06 & 0.08 \\
\hline $\operatorname{rch} 189$ & 189 & $\begin{array}{l}\text { rech_inplace } \\
\text { rech_runoff } \\
\text { rech_base }\end{array}$ & 189A, 189B, 189C, 189D & 0.45 & 0.33 & 0.58 & 0.06 \\
\hline $\operatorname{rch} 202$ & 202 & $\begin{array}{l}\text { rech_inplace } \\
\text { rech_runoff } \\
\text { rech_base }\end{array}$ & $171,181-183,198-206,208-210,216-221,254$ & 0.19 & 0.16 & 0.23 & 0.02 \\
\hline $\operatorname{rch} 204$ & 204 & $\begin{array}{l}\text { rech_inplace } \\
\text { rech_runoff } \\
\text { rech_base }\end{array}$ & 204 & 0.40 & 0.18 & 0.62 & 0.11 \\
\hline $\operatorname{rch} 207$ & 207 & $\begin{array}{l}\text { rech_inplace } \\
\text { rech_runoff } \\
\text { rech_base }\end{array}$ & 180,207 & 1.40 & 0.90 & 1.90 & 0.25 \\
\hline $\operatorname{rch} 212$ & 212 & $\begin{array}{l}\text { rech_inplace } \\
\text { rech_runoff } \\
\text { rech_base }\end{array}$ & $164 \mathrm{~A}, 164 \mathrm{~B}, 165-167,212,215$ & 0.99 & 0.75 & 1.23 & 0.12 \\
\hline $\operatorname{rch} 222$ & 222 & $\begin{array}{l}\text { rech_inplace } \\
\text { rech_runoff } \\
\text { rech_base }\end{array}$ & 204,222 & 0.50 & 0.41 & 0.60 & 0.05 \\
\hline $\operatorname{rch} 251$ & 251 & $\begin{array}{l}\text { rech_inplace } \\
\text { rech_runoff } \\
\text { rech_base }\end{array}$ & $189 \mathrm{D}, 191,251,252$ & 2.30 & 1.73 & 2.87 & 0.29 \\
\hline $\operatorname{rch} 254$ & 254 & $\begin{array}{l}\text { rech_inplace } \\
\text { rech_runoff } \\
\text { rech_base }\end{array}$ & $253,254,257,258$ & 1.12 & 0.92 & 1.32 & 0.10 \\
\hline $\operatorname{rch} 259$ & 259 & $\begin{array}{l}\text { rech_inplace } \\
\text { rech_runoff } \\
\text { rech_base }\end{array}$ & $257-259,263,270,285$ & 1.22 & 0.94 & 1.51 & 0.15 \\
\hline $\operatorname{rch} 260$ & 260 & $\begin{array}{l}\text { rech_inplace } \\
\text { rech_runoff } \\
\text { rech_base }\end{array}$ & $260 \mathrm{~A}, 260 \mathrm{~B}, 274,277,278$ & 3.24 & 2.63 & 3.85 & 0.31 \\
\hline $\operatorname{rch} 262$ & 262 & $\begin{array}{l}\text { rech_inplace } \\
\text { rech_runoff } \\
\text { rech_base }\end{array}$ & $261 \mathrm{~B}, 262,269,271,279$ & 1.11 & 0.56 & 1.66 & 0.28 \\
\hline $\operatorname{rch} 263$ & 263 & $\begin{array}{l}\text { rech_inplace } \\
\text { rech_runoff } \\
\text { rech_base }\end{array}$ & $262-265$ & 0.46 & 0.34 & 0.58 & 0.06 \\
\hline $\operatorname{rch} 265$ & 265 & $\begin{array}{l}\text { rech_inplace } \\
\text { rech_runoff } \\
\text { rech_base } \\
\text { rech_import }\end{array}$ & 265,267 & 1.04 & 0.88 & 1.19 & 0.08 \\
\hline $\operatorname{rch} 266$ & 266 & $\begin{array}{l}\text { rech_inplace } \\
\text { rech_runoff } \\
\text { rech_base }\end{array}$ & $263,265,266,287$ & 1.50 & 1.21 & 1.78 & 0.15 \\
\hline $\operatorname{rch} 267$ & 267,2671 & $\begin{array}{l}\text { rech_inplace } \\
\text { rech_runoff } \\
\text { rech_base } \\
\text { rech_import }\end{array}$ & 267 & 1.20 & 0.86 & 1.55 & 0.18 \\
\hline
\end{tabular}


Table A4-4. Model zones, multiplier arrays, and parameter values and statistics for recharge and lateral flow boundaries in the numerical groundwater flow model, Great Basin carbonate and alluvial aquifer system study area.-Continued

[Parameter value: multiplier of the conceptual recharge rate defined by the model multiplier arrays. 95-percent confidence interval: 95 -percent linear confidence interval calculated by UCODE_2005 (Poeter and others, 2008, p. 174). Standard deviation: calculated by UCODE_2005 (Poeter and others, 2008). Abbreviations: HA, hydrographic area; \#, number; - , not applicable]

\begin{tabular}{|c|c|c|c|c|c|c|c|}
\hline \multirow{3}{*}{$\begin{array}{l}\text { Parameter } \\
\text { name }\end{array}$} & \multirow{3}{*}{$\begin{array}{l}\text { Model } \\
\text { recharge } \\
\text { zones }\end{array}$} & \multirow{3}{*}{ Model multiplier arrays } & \multirow{3}{*}{ Location by HA \# } & \multicolumn{4}{|c|}{ Model estimate of recharge parameter, dimensionless } \\
\hline & & & & \multirow{2}{*}{$\begin{array}{l}\text { Parameter } \\
\text { value }\end{array}$} & \multicolumn{2}{|c|}{ 95-percent confidence interval } & \multirow{2}{*}{$\begin{array}{l}\text { Standard } \\
\text { deviation }\end{array}$} \\
\hline & & & & & Low value & High value & \\
\hline rchrun 2671 & 2671 & $\begin{array}{l}\text { rech_runoff } \\
\text { rech_base } \\
\text { rech_import }\end{array}$ & 262,267 & 1.00 & 0.70 & 1.30 & 0.15 \\
\hline $\operatorname{rch} 270$ & 270 & $\begin{array}{l}\text { rech_inplace } \\
\text { rech_runoff } \\
\text { rech_base }\end{array}$ & $261 \mathrm{~A}, 262,270$ & 1.94 & 1.12 & 2.76 & 0.42 \\
\hline $\operatorname{rch} 272$ & 272 & $\begin{array}{l}\text { rech_inplace } \\
\text { rech_import }\end{array}$ & 272,273 & 0.91 & 0.75 & 1.07 & 0.08 \\
\hline rchrun 272 & 272 & $\begin{array}{l}\text { rech_runoff } \\
\text { rech_base }\end{array}$ & 272 & 1.33 & 0.84 & 1.82 & 0.25 \\
\hline $\operatorname{rch} 273$ & 273 & $\begin{array}{l}\text { rech_inplace } \\
\text { rech_runoff } \\
\text { rech_base }\end{array}$ & $268,272-274$ & 1.47 & 1.14 & 1.79 & 0.17 \\
\hline rchimp273 & 273 & rech_import & 273 & 0.50 & 0.35 & 0.65 & 0.08 \\
\hline $\operatorname{rch} 275$ & 275 & $\begin{array}{l}\text { rech_inplace } \\
\text { rech_runoff } \\
\text { rech_base }\end{array}$ & $273,275,276$ & 6.47 & 5.58 & 7.37 & 0.46 \\
\hline $\operatorname{rch} 280$ & 280 & $\begin{array}{l}\text { rech_inplace } \\
\text { rech_runoff } \\
\text { rech_base }\end{array}$ & 280,282 & 0.44 & 0.30 & 0.58 & 0.07 \\
\hline $\operatorname{rch} 281$ & 281 & $\begin{array}{l}\text { rech_inplace } \\
\text { rech_runoff } \\
\text { rech_base }\end{array}$ & $280-282$ & 1.21 & 0.78 & 1.63 & 0.22 \\
\hline $\operatorname{rch} 282$ & 282 & $\begin{array}{l}\text { rech_inplace } \\
\text { rech_runoff } \\
\text { rech_base }\end{array}$ & 282 & 1.82 & 0.99 & 2.65 & 0.42 \\
\hline $\operatorname{rch} 283$ & 283 & $\begin{array}{l}\text { rech_inplace } \\
\text { rech_runoff } \\
\text { rech_base }\end{array}$ & 283,284 & 1.03 & 0.82 & 1.24 & 0.11 \\
\hline $\operatorname{rch} 286$ & 286 & $\begin{array}{l}\text { rech_inplace } \\
\text { rech_runoff } \\
\text { rech_base } \\
\text { rech_import }\end{array}$ & $283-287$ & 1.46 & 1.08 & 1.85 & 0.20 \\
\hline $\operatorname{rch} 364$ & 364 & $\begin{array}{l}\text { rech_inplace } \\
\text { rech_runoff } \\
\text { rech_base }\end{array}$ & $164 \mathrm{~B}, 245$ & 1.33 & 0.88 & 1.78 & 0.23 \\
\hline rch999 & 999 & $\begin{array}{l}\text { rech_inplace } \\
\text { rech_runoff } \\
\text { rech_base } \\
\text { rech_import }\end{array}$ & scattered & 0.10 & 0.08 & 0.12 & 0.01 \\
\hline rch9999 & 9999 & $\begin{array}{l}\text { rech_inplace } \\
\text { rech_runoff } \\
\text { rech_base } \\
\text { rech_import }\end{array}$ & scattered & 0.01 & -0.85 & 0.87 & 0.44 \\
\hline in_ha59 & - & $\begin{array}{l}\text { Inflow wells at lateral } \\
\text { boundary }\end{array}$ & 59 & 1.00 & 0.41 & 1.59 & 0.30 \\
\hline out_ha167 & - & $\begin{array}{l}\text { Outflow wells at } \\
\text { lateral boundary }\end{array}$ & 167 & 1.00 & 0.34 & 1.66 & 0.34 \\
\hline
\end{tabular}




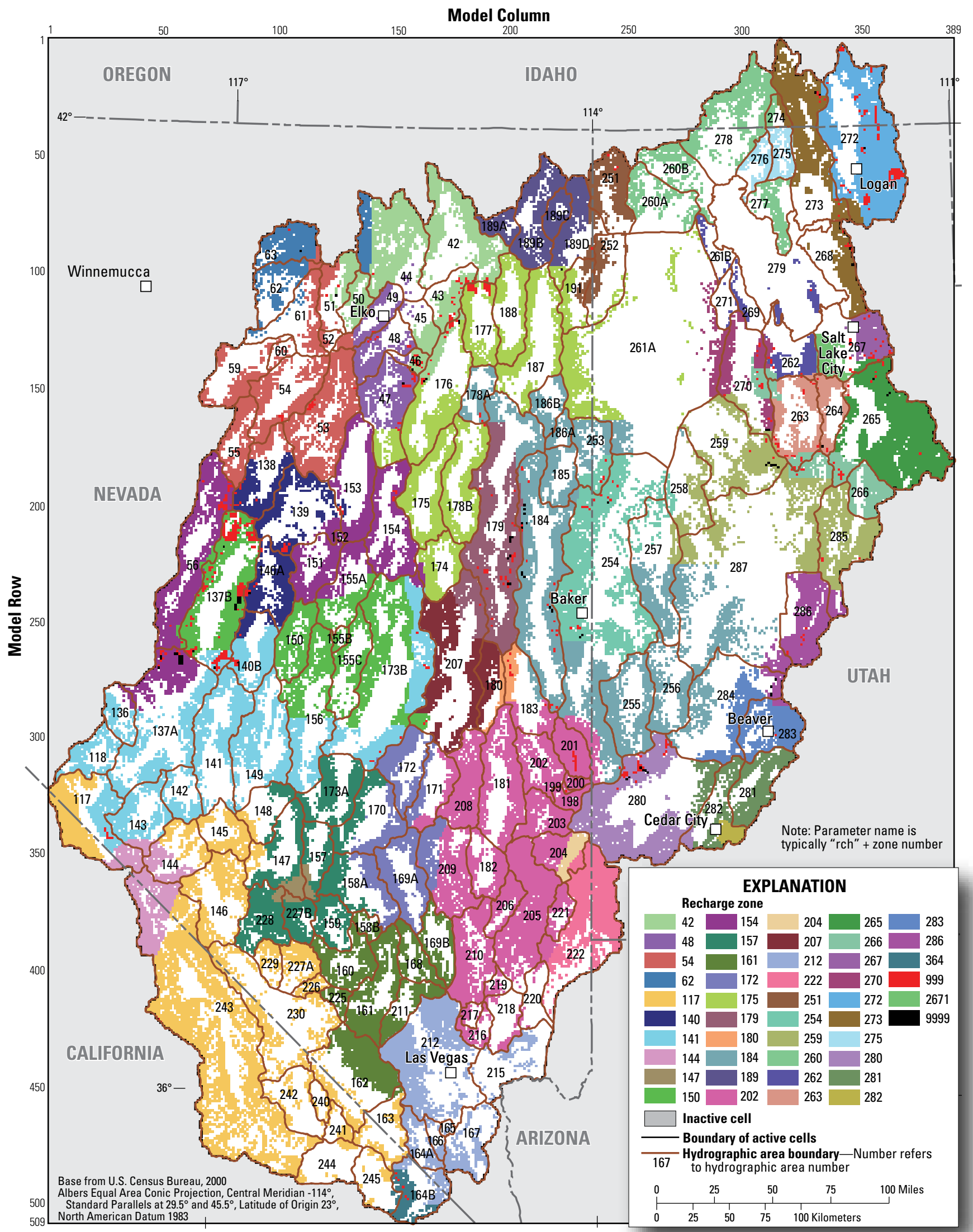

Figure A4-6. Distribution of recharge parameters in the numerical groundwater flow model, Great Basin carbonate and alluvial aquifer system study area. 
Table A4-5. Parameter values and statistics for horizontal-to-vertical anisotropy of all hydrogeologic units in the numerical groundwater flow model, Great Basin carbonate and alluvial aquifer system study area.

[Model zone: zone number used in MODFLOW files. 95-percent confidence interval: 95-percent linear confidence interval as calculated by UCODE 2005 (Poeter and others, 2008, p. 174). Standard deviation of log values: calculated by UCODE_2005 (Poeter and others, 2008). Abbreviations: HGU, hydrogeologic unit; NCCU, non-carbonate confining unit; TNCCU, thrusted non-carbonate confiing unit; LCAU, lower carbonate aquifer unit; TLCAU, thrusted lower carbonate aquifer unit; USCU, upper siliciclastic confining unit; UCAU, upper carbonate aquifer unit; VU, volcanic unit; LBFAU, lower basin-fill aquifer unit; UBFAU, upper basin-fill aquifer unit]

\begin{tabular}{|c|c|c|c|c|c|c|}
\hline \multirow{3}{*}{$\begin{array}{c}\text { Model } \\
\text { parameter } \\
\text { name }\end{array}$} & \multirow{3}{*}{ HGU } & \multirow{3}{*}{ Model zone } & \multicolumn{4}{|c|}{ Model estimate of horizontal-to-vertical anisotropy (rounded) } \\
\hline & & & \multirow[b]{2}{*}{$\begin{array}{l}\text { Parameter } \\
\text { value, in feet } \\
\text { per day }\end{array}$} & \multicolumn{2}{|c|}{ 95-percent confidence interval } & \multirow[b]{2}{*}{$\begin{array}{c}\text { Standard } \\
\text { deviation of } \log \\
\text { values }\end{array}$} \\
\hline & & & & $\begin{array}{l}\text { Low value, } \\
\text { dimensionless }\end{array}$ & $\begin{array}{l}\text { High value, } \\
\text { dimensionless }\end{array}$ & \\
\hline \multirow{16}{*}{ rock_vn } & $\mathrm{NCCU}$ & All & \multirow{16}{*}{1} & \multirow{16}{*}{0.68} & \multirow{16}{*}{1.5} & \multirow{16}{*}{0.085} \\
\hline & TNCCU & All & & & & \\
\hline & LCAU & All & & & & \\
\hline & TLCAU & All & & & & \\
\hline & USCU & All & & & & \\
\hline & UCAU & All & & & & \\
\hline & VU & All except 120 & & & & \\
\hline & LBFAU & 1 & & & & \\
\hline & LBFAU & 2 & & & & \\
\hline & LBFAU & 21 & & & & \\
\hline & LBFAU & 24 & & & & \\
\hline & LBFAU & 25 & & & & \\
\hline & LBFAU & 26 & & & & \\
\hline & LBFAU & 3 & & & & \\
\hline & LBFAU & 99 & & & & \\
\hline & UBFAU & 99 & & & & \\
\hline \multirow{16}{*}{ bfau_vn } & VU & 120 & \multirow{16}{*}{11} & \multirow{16}{*}{4.5} & \multirow{16}{*}{26} & \multirow{16}{*}{0.19} \\
\hline & LBFAU & 4 & & & & \\
\hline & LBFAU & 5 & & & & \\
\hline & UBFAU & 1 & & & & \\
\hline & UBFAU & 11 & & & & \\
\hline & UBFAU & 12 & & & & \\
\hline & UBFAU & 13 & & & & \\
\hline & UBFAU & 2 & & & & \\
\hline & UBFAU & 23 & & & & \\
\hline & UBFAU & 4 & & & & \\
\hline & UBFAU & 41 & & & & \\
\hline & UBFAU & 42 & & & & \\
\hline & UBFAU & 44 & & & & \\
\hline & UBFAU & 45 & & & & \\
\hline & UBFAU & 48 & & & & \\
\hline & UBFAU & 49 & & & & \\
\hline \multirow{7}{*}{ playa_vn } & LBFAU & 501 & \multirow{7}{*}{66} & \multirow{7}{*}{35} & \multirow{7}{*}{120} & \multirow{7}{*}{0.14} \\
\hline & UBFAU & 3 & & & & \\
\hline & UBFAU & 31 & & & & \\
\hline & UBFAU & 34 & & & & \\
\hline & UBFAU & 35 & & & & \\
\hline & UBFAU & 36 & & & & \\
\hline & UBFAU & 481 & & & & \\
\hline & UBFAU & 122 & & & & \\
\hline & UBFAU & 232 & & & & \\
\hline playa $2 v n$ & UBFAU & 312 & 990 & 300 & 3,300 & 0.27 \\
\hline & UBFAU & 342 & & & & \\
\hline & UBFAU & 352 & & & & \\
\hline
\end{tabular}




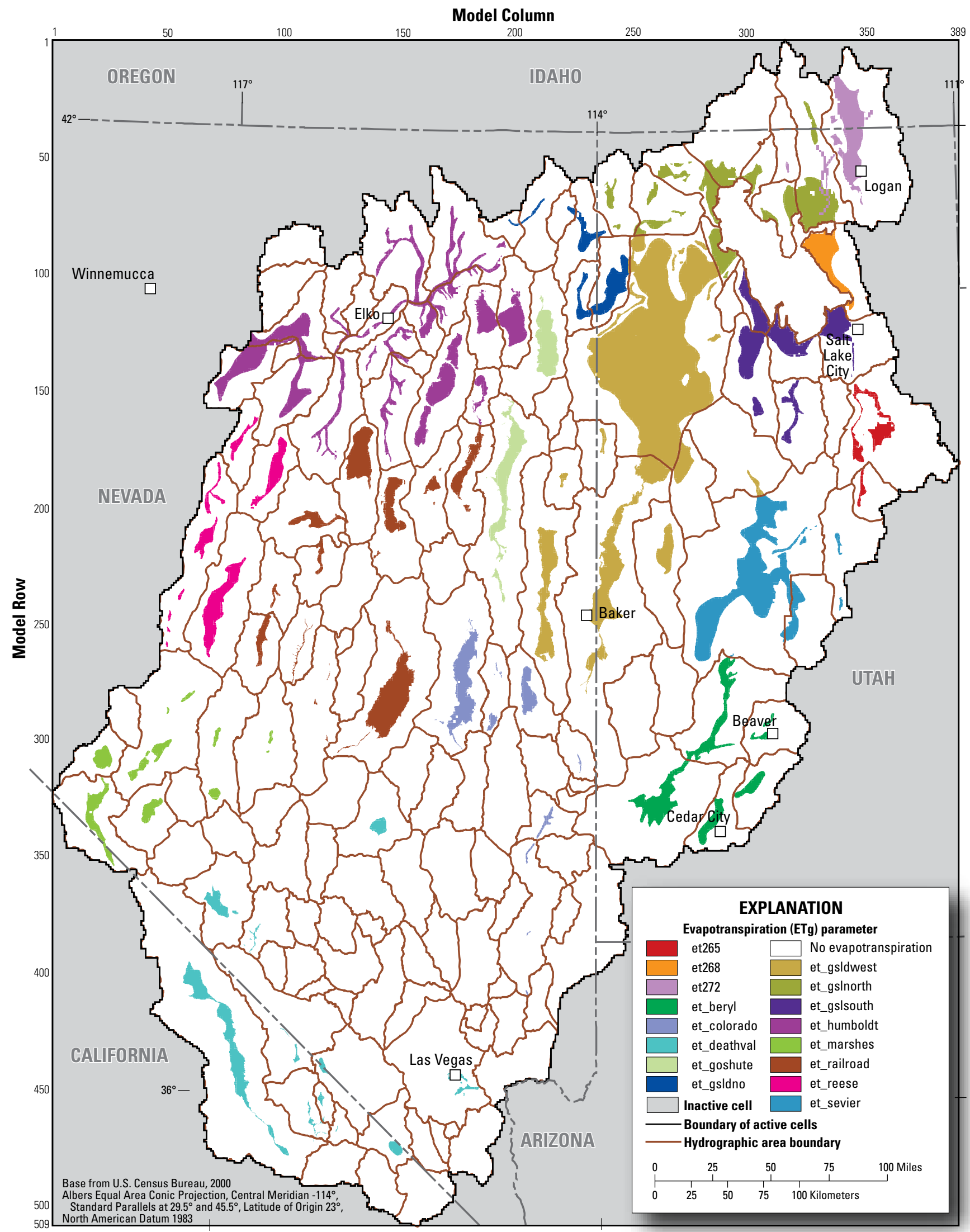

Figure A4-7. Distribution of evapotranspiration parameters in the numerical groundwater flow model, Great Basin carbonate and alluvial aquifer system study area. 
Table A4-6. Parameter values and statistics for evapotranspiration, drain conductance, and river conductance in the numerical groundwater flow model, Great Basin carbonate and alluvial aquifer system study area.

[Parameter name: evapotranspiration (et), dimensionless multipliers of the conductance; discharge, day ${ }^{-1}$ for drains, feet per day for rivers; river, feet per day. 95-percent confidence interval: 95-percent linear confidence interval as calculated by UCODE 2005 (Poeter and others, 2008, p. 174). Standard deviation of log values: calculated by UCODE_2005 (Poeter and others, 2008). Abbreviations: HA, hydrographic area; \#, number; - , not applicable]

\begin{tabular}{|c|c|c|c|c|c|}
\hline \multirow{3}{*}{ Parameter name } & \multirow{3}{*}{ Location by HA \# } & \multicolumn{4}{|c|}{ Model estimate of parameter } \\
\hline & & \multirow[b]{2}{*}{$\begin{array}{l}\text { Parameter } \\
\text { value }\end{array}$} & \multicolumn{2}{|c|}{ 95-percent confidence interval } & \multirow[b]{2}{*}{$\begin{array}{c}\text { Standard } \\
\text { deviation of } \\
\text { log values }\end{array}$} \\
\hline & & & Low value & High value & \\
\hline et_beryl & 280 to 284 & 1.37 & 1.00 & 1.88 & 0.07 \\
\hline et_colorado & $180,183,201,203,205,207$ & 0.95 & 0.65 & 1.39 & 0.08 \\
\hline et_deathval & $146,162,163,170,212,228,230,240,241,242,243$ & 2.00 & 1.24 & 3.22 & 0.11 \\
\hline et_goshute & 179,187 & 1.94 & 1.01 & 3.73 & 0.14 \\
\hline et_gsldno & 189A, 189B, 189C, 189D, 191, 252 & 0.98 & 0.64 & 1.52 & 0.10 \\
\hline et_gsldwest & $184,185,253,254,257,258,259,261 \mathrm{~A}$ & 1.11 & 0.93 & 1.32 & 0.04 \\
\hline et_gslnorth & $251,260 \mathrm{~A}, 260 \mathrm{~B}, 261 \mathrm{~B}, 273,276,277,278$ & 2.50 & 1.41 & 4.45 & 0.13 \\
\hline et_gslsouth & $262,263,267,269,270$ & 2.00 & 1.09 & 3.67 & 0.13 \\
\hline et_humboldt & 42 to 54,59 to $61,176,177,178 \mathrm{~A}, 188$ & 1.43 & 1.07 & 1.92 & 0.06 \\
\hline et_marshes & $117,118,137 \mathrm{~A}, 141,143,149$ & 1.01 & 0.71 & 1.45 & 0.08 \\
\hline et_railroad & $139,140 \mathrm{~A}, 140 \mathrm{~B}, 150,151,153,154,156,173 \mathrm{~B}, 178 \mathrm{~B}$ & 1.12 & 0.78 & 1.60 & 0.08 \\
\hline et_reese & $55,56,137 \mathrm{~B}, 138$ & 0.98 & 0.61 & 1.58 & 0.11 \\
\hline et_sevier & 285 to 287 & 2.22 & 1.33 & 3.70 & 0.11 \\
\hline et265 & 265,266 & 1.50 & 0.93 & 2.43 & 0.11 \\
\hline et268 & 268 & 0.99 & 0.61 & 1.60 & 0.11 \\
\hline et 272 & $272,273,275$ & 1.30 & 0.82 & 2.05 & 0.10 \\
\hline discharge & - & 0.50 & 0.22 & 1.12 & 0.18 \\
\hline river & - & 50 & 0.39 & 6,300 & 1.07 \\
\hline
\end{tabular}

Table A4-7. Parameter values and statistics for the hydraulic characteristic of horizontal-flow barriers in the numerical groundwater flow model, Great Basin carbonate and alluvial aquifer system study area.

[95-percent confidence interval: 95 -percent linear confidence interval as calculated by UCODE 2005 (Poeter and others, 2008, p. 174). Standard deviation of log values: calculated by UCODE_2005 (Poeter and others, 2008)]

\begin{tabular}{|c|c|c|c|c|}
\hline \multirow{3}{*}{$\begin{array}{c}\text { Model } \\
\text { parameter } \\
\text { name }\end{array}$} & \multicolumn{4}{|c|}{ Model estimate of hydraulic characteristic of horizontal-flow barrier } \\
\hline & \multirow[b]{2}{*}{$\begin{array}{c}\text { Parameter } \\
\text { value, } \\
\text { in feet per day }\end{array}$} & \multicolumn{2}{|c|}{ 95-percent confidence interval } & \multirow[b]{2}{*}{$\begin{array}{c}\text { Standard } \\
\text { deviation of log } \\
\text { values }\end{array}$} \\
\hline & & $\begin{array}{l}\text { Low value, } \\
\text { in feet per day }\end{array}$ & $\begin{array}{l}\text { High value, } \\
\text { in feet per day }\end{array}$ & \\
\hline b_hfb1 & $1.0 \times 10^{-8}$ & $1.4 \times 10^{-10}$ & $7.3 \times 10^{-7}$ & 0.95 \\
\hline b_deepck & $1.4 \times 10^{-7}$ & $6.2 \times 10^{-8}$ & $3.1 \times 10^{-7}$ & 0.18 \\
\hline b_dv_n2 & $1.8 \times 10^{-7}$ & $7.9 \times 10^{-8}$ & $4.0 \times 10^{-7}$ & 0.18 \\
\hline b_steptoe & $2.7 \times 10^{-7}$ & $1.0 \times 10^{-7}$ & $6.9 \times 10^{-7}$ & 0.21 \\
\hline b_hfb2 & $5.0 \times 10^{-7}$ & $2.6 \times 10^{-8}$ & $9.7 \times 10^{-6}$ & 0.66 \\
\hline b_lvvsz & $1.1 \times 10^{-6}$ & $8.0 \times 10^{-8}$ & $1.4 \times 10^{-5}$ & 0.57 \\
\hline b_spring & $1.0 \times 10^{-5}$ & $6.7 \times 10^{-9}$ & $1.5 \times 10^{-2}$ & 1.6 \\
\hline
\end{tabular}





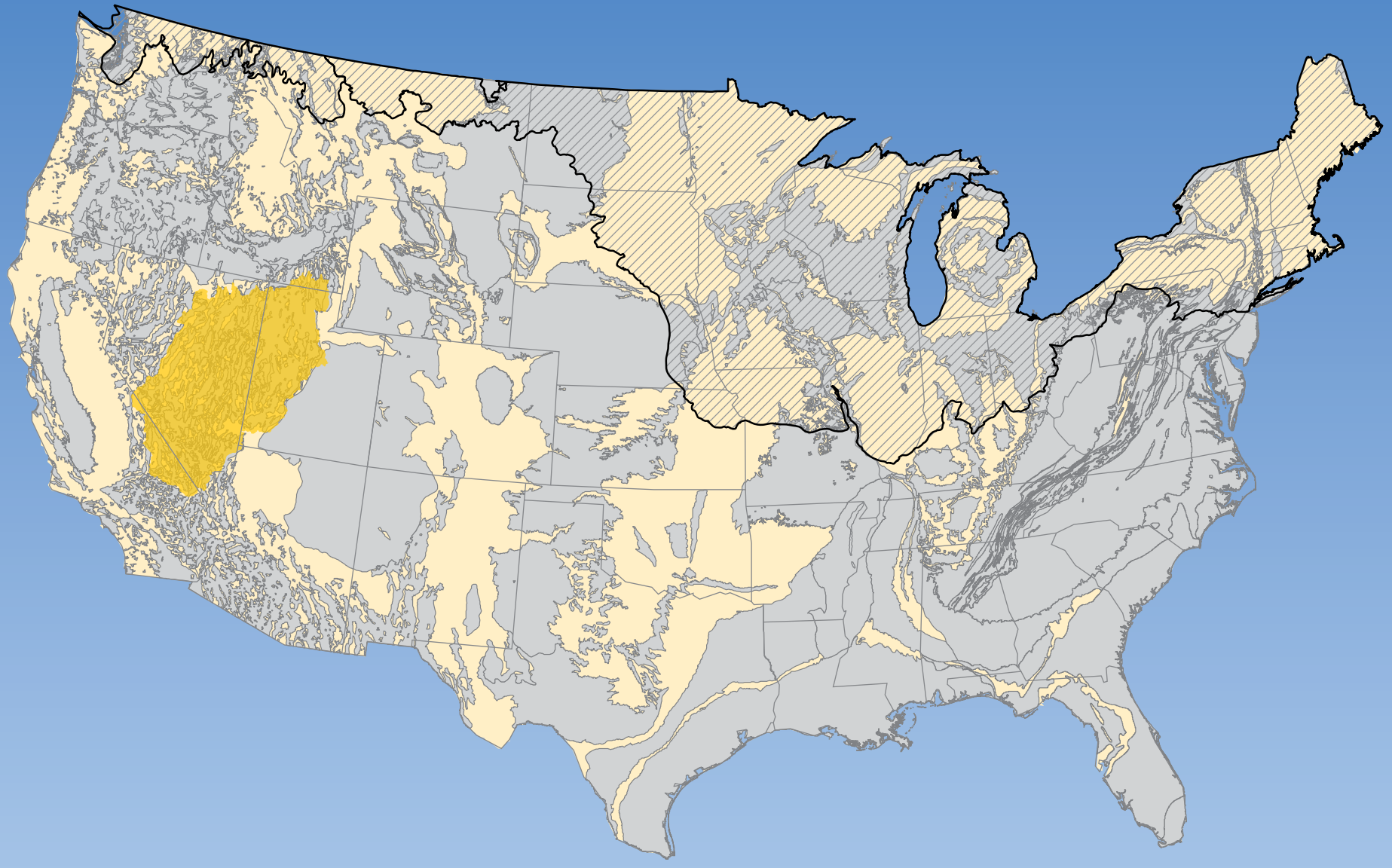

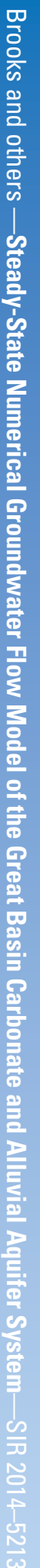

